\title{
EFEITOS DOS NÍVEIS DE MONENSINA E PROPORÇÕES VOLUMOSOS/CONCENTRADOS NA RAÇÃO SOBRE A UTILIZAÇÃO DOS ALIMENTOS E PARÂMETROS DA FERMENTAÇÃO RUMINAL EM ANIMAIS RUMINANTES
}

\section{PAULO HENRIQUE MAZZA RODRIGUES Médico Veterinário}

Orientador: Prof. Dr. WILSON ROBERTO SOARES MATTOS

\begin{abstract}
Tese apresentada à Escola Superior de Agricultura "Luiz de Queiroz", Universidade de São Paulo, para obtenção do título de Doutor em Agronomia. Área de Concentração: Ciência Animal e Pastagens.
\end{abstract}

PIRACICABA

Estado de São Paulo - Brasil

Maio - 2000 
Errata:

Ficha Catalográfica: Onde se lê

"Dissertação (mestrado)" substitua por

"Tese (doutorado)".

\title{
Dados Internacionais de Catalogação na Publicaçāo (CIP) DIVISĀO DE BIBLIOTECA E DOCUMENTAÇĀO - Campus "Luiz de Queiroz"/USP
}

\author{
Rodrigues, Paulo Henrique Mazza \\ Efeitos dos niveis de monensina e proporções volumosos/concentrados na ração \\ sobre a utilização dos alimentos e parâmetros da fermentação ruminal em animais \\ ruminantes / Paulo Henrique Mazza Rodrigues. - - Piracicaba, 2000. \\ 169 p. : il. \\ Dissertação (mestrado) - - Escola Superior de Agricultura Luiz de Queiroz, 2000. \\ Bibliografia. \\ 1. Ácido graxo volátil 2. Bovino 3. Digestão 4. Fermentação ruminal 5. Fibra 6. \\ Inóforo 7. Nutrição animal 8. Ovino I. Titulo
}

CDD 636.2085 


\section{DEDICO}

À minha mãe,

quem nunca lamentou a ausência dos filhos. 
Toda a nossa ciência, comparada com a realidade, é primitiva e infantil - e, no entanto, é a coisa mais preciosa que temos.

ALBERT EINSTEIN (1879-1955) 


\section{AGRADECIMENTOS}

Ao Professor Doutor Wilson Roberto Soares Mattos, pela amizade, incentivo, dedicação e orientação na execução deste trabalho.

Aos professores coordenadores da pós-graduação, Prof. Dr. Alexandre Vaz Pires e Prof. Dr. Sila Carneiro da Silva, pela valiosa colaboração durante minha estadia na ESALQ.

Aos Professores Doutores Dante Lanna, Flávio Santos, Ivanete Susin, Irineu Packer, José Simas, Luiz Coutinho, Luiz Gustavo Nússio, Luiz Gutierres, Paulo Machado e demais professores do Departamento de Produção Animal da ESALQ/USP, pela paciência e dedicação.

Aos colegas do curso de Pós-Graduação Alfredo Pereira, Carla Nússio, Cláudio Ribeiro, Éberson Barnabé, Flávio Castro, Hugo Imaizumi, José Renato, Laísse Lima, Luiz Fernando, Marco Antônio Balsalobre, Milton Lima, Reinaldo Oliveira, Ricardo Manzano, Sérgio Juchem, Sérgio Raposo e especialmente ao Paulo Garcez e Adriana Bagaldo pelo companherismo em todos os momentos.

momentos.

À Paula Meyer, pela paciência e por estar sempre perto, nos bons e maus

Ao Professor Doutor Carlos Silveira Pedreira, pelas dicas com as análises estatísticas.

Ao colega Luiz Gustavo Barion, pelas dicas com os gráficos.

À secretária Cleide, pelos recados anotados e as correspondências enviadas.

À Faculdade de Medicina Veterinária e Zootecnia da USP, pela liberação durante esses dois anos e meio. depositada.

Ao Professor Doutor Carlos de Sousa Lucci, pela confiança em mim

Ao amigo, pai, irmão, Professor Doutor Laércio Melotti, por ter me ensinado coisas que não se aprende nas Universidades. 
Aos professores e amigos Felix Ribeiro de Lima, Luis Fernando Laranja da Fonseca e Stefano Juliano Tavares de Andrade do Departamento de Nutrição e Produção Animal da FMVZ/USP, pelo apoio durante esta jornada. experimento.

À Médica Veterinária Ana Lúcia Senatore, pela ajuda na execução do

Aos técnicos Ari, Gilson e Simi, pela ajuda com as análises bromatológicas.

Ao Everson e Gilmar, pelo cuidado incessante com os animais.

À ELANCO do Brasil, pelo fornecimento da monensina.

À Prefeitura do Campus Administrativo de Pirassununga, particularmente à Fábrica de Ração, pela facilidade com a mistura de concentrados.

À FAPESP, pelo auxílio financeiro.

Aos animais, sem os quais não seria possível a realização deste trabalho. 


\section{SUMÁRIO}

Página

AGRADECIMENTOS …............................................................................... i

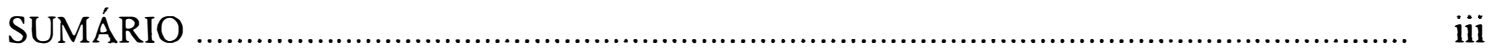

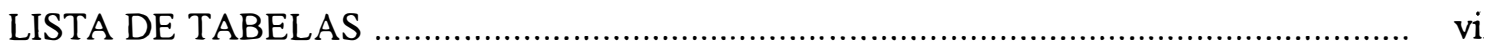

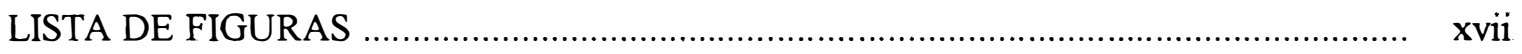

LISTA DE ABREVIATURAS ....................................................................

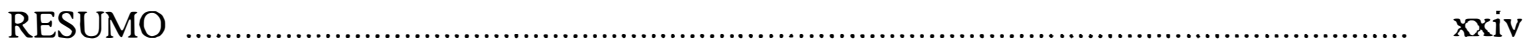

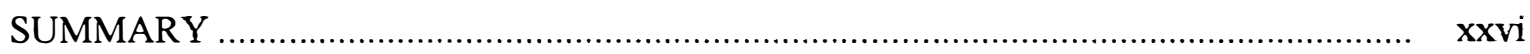

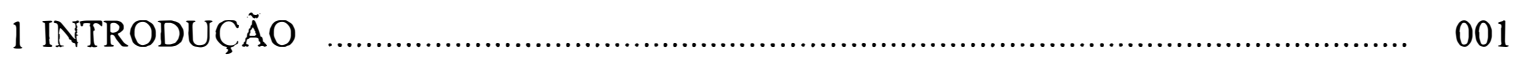

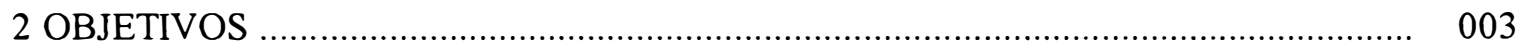

3 REVISÃO DE LITERATURA _..................................................................... 004

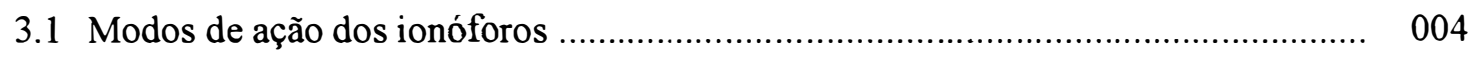

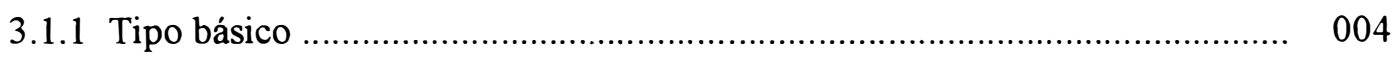

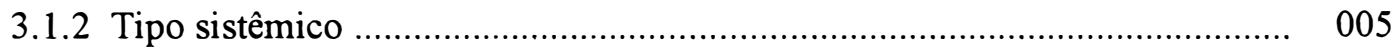

3.1.2.1 Produção de AGVs ................................................................. 006

3.1.2.2 Consumo de alimentos .......................................................... 009

3.1.2.3 Produção de metano ................................................................ 011

3.1.2.4 Digestibilidade e degradabilidade ........................................... 012

3.1.2.5 Utilização da proteína ........................................................... 016

3.1.2.6 Volume ruminal e taxa de passagem de líquidos ....................... 020

3.1.2.7 Outros …..................................................................... 021

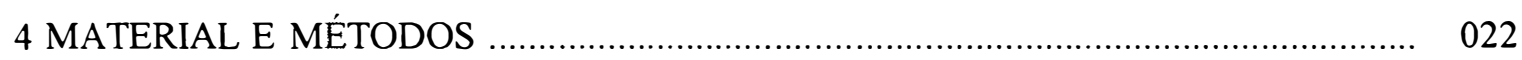

4.1 Experimento 1 - Bovinos ............................................................................... 022

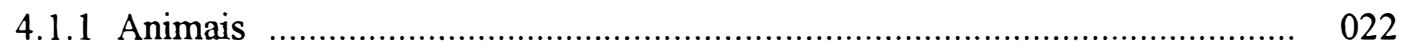

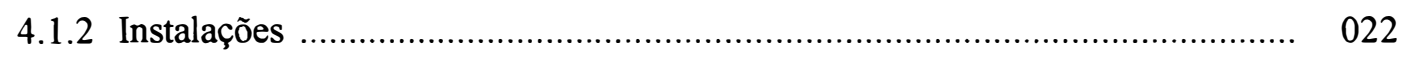

4.1.3 Tratamentos e delineamento experimental ......................................... 023

4.1.4 Período experimental ............................................................................. 024

4.1.4.1 Descrição das coletas de conteúdo ruminal ................................ 025 
Página

4.1.5 Métodos analíticos .......................................................................... 026

4.1.5.1 Metodologia de determinação do $\mathrm{pH}$ do conteúdo ruminal ........... 026

4.1.5.2 Metodologia de determinação dos AGVs .................................. 026

4.1.5.3 Metodologia de determinação da concentração de $\mathrm{N}$ amoniacal .... 027

4.1.5.4 Metodologia de determinação da digestibilidade in situ ............... 028

4.1.5.5 Metodologia de determinação da digestibilidade in vivo ............... 031

4.1.5.6 Metodologia de determinação da digestibilidade in vitro .............. 031

4.1.5.7 Metodologia de determinação do volume e taxa de passagem ....... 032

4.1.6 Análise estatística .............................................................................. 033

4.2 Experimento 2 - Ovinos .............................................................................. 036

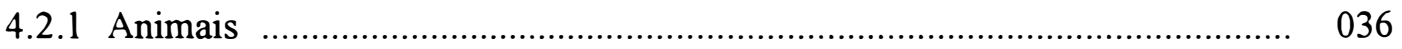

4.2.2 Instalações ....................................................................................... 036

4.2.3 Tratamentos e delineamento experimental .......................................... 036

4.2.4 Período experimental ........................................................................ 038

4.2.5 Descrição das coletas de fezes e urina ...................................................... 038

4.2.6 Métodos analíticos ....................................................................... 038

4.2.7 Análise estatística ................................................................................ 039

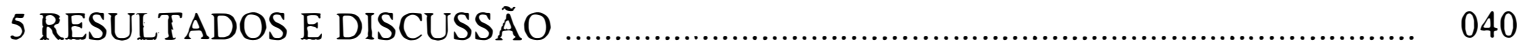

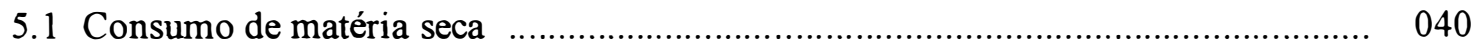

$5.2 \mathrm{pH}$ do conteúdo ruminal ............................................................................. 047

5.3 Proporção molar de AGVs no líquido ruminal ................................................. 054

5.4 Concentração de nitrogênio amoniacal no líquido ruminal ................................. 081

5.5 Digestibilidade ruminal in situ da fibra do feno ............................................. 089

5.6 Digestibilidade ruminal in situ da proteína do farelo de soja ........................... 101

5.7 Digestibilidade ruminal in situ dos grãos de milho ........................................ 108

5.8 Digestibilidade aparente in vivo ....................................................................... 114 
Página

5.8.1 Digestibilidade aparente da matéria seca ........................................... 114

5.8.2 Digestibilidade aparente da fibra .................................................... 116

5.8.3 Digestibilidade aparente da proteína bruta ............................................... 118

5.8.4 Digestibilidade aparente do extrato etéreo .............................................. 120

5.8.5 NDT e digestibilidade aparente dos extrativos não nitrogenados ................. 121

5.9 Digestibilidade in vivo (etapa ruminal) do farelo de soja ................................ 137

5.10 Retenção nitrogenada .......................................................................... 143

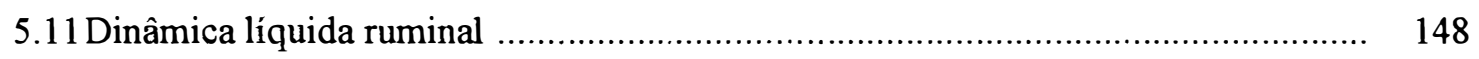

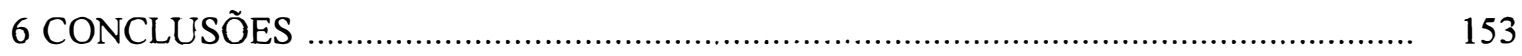

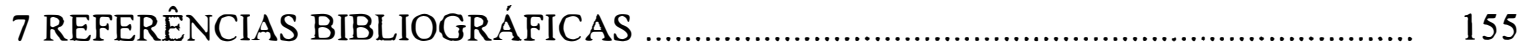




\section{LISTA DE TABELAS}

Página

Tabela 01 - Delineamento inteiramente casualizado, com 9 animais e 3 subperíodos

Tabela 02 - Proporções de ingredientes e composição bromatológica das rações utilizadas no experimento com bovinos, com base na matéria seca

Tabela 03 - Esquema da análise de variância em delineamento inteiramente casualizado com 7 medidas repetidas no tempo

Tabela 04 - Proporções de ingredientes e composição bromatológica das rações utilizadas no experimento com ovinos, com base na matéria seca ...

Tabela 05 - Esquema da análise de variância em delineamento inteiramente casualizado

Tabela 06 - Efeitos da proporção de concentrados (Con) e dose de monensina (Mon) sobre o consumo diário de matéria seca (CMS), em quilos, consumo diário de matéria seca por quilo de peso vivo (CMS/kgPV), em porcentagem do peso vivo, e consumo diário de matéria seca por quilo de peso metabólico $\left(\mathrm{CMS} / \mathrm{kgP}^{0,75}\right)$, em gramas, coeficientes de variação $(\mathrm{CV})$ e probabilidades estatísticas no experimento com bovinos 
Página

Tabela 07 - Coeficientes de regressão e de determinação $\left(R^{2}\right)$ para as variáveis consumo diário de matéria seca (CMS), em quilos, consumo diário de matéria seca por quilo de peso vivo (CMS/kgPV), em porcentagem do peso vivo, e consumo diário de matéria seca por quilo de peso metabólico $\left(\mathrm{CMS}_{\mathrm{kgP}} \mathrm{k}^{0,75}\right)$, em gramas, no experimento com bovinos

Tabela 08 - Efeitos da proporção de concentrados (Con) e dose de monensina (Mon) sobre o consumo diário de matéria seca (CMS), em quilos, consumo diário de matéria seca por quilo de peso vivo (CMS/kgPV), em porcentagem do peso vivo, e consumo diário de matéria seca por quilo de peso metabólico $\left(\mathrm{CMS} / \mathrm{kgP}^{0,75}\right)$, em gramas, coeficientes de variação $(\mathrm{CV})$ e probabilidades estatísticas no experimento com ovinos

Tabela 09 - Efeitos da proporção de concentrados (Con) e dose de monensina (Mon) sobre o $\mathrm{pH}$ do líquido ruminal, em diferentes horas de amostragem, coeficientes de variação $(\mathrm{CV})$ e probabilidades estatísticas no experimento com bovinos

Tabela 10 - Coeficientes de regressão e de determinação $\left(R^{2}\right)$ para a variável $\mathrm{pH}$ do líquido ruminal, em diferentes horas de amostragem no experimento com bovinos 
Tabela 11 - Efeitos da proporção de concentrados (Con) e dose de monensina (Mon) sobre as concentrações de AGVs maiores $\left(C_{2}+C_{3}+C_{4}\right)$ no líquido ruminal (mM), em diferentes horas de amostragem, coeficientes de variação $(\mathrm{CV})$ e probabilidades estatísticas no experimento com bovinos

Tabela 12 - Coeficientes de regressão e de determinação $\left(R^{2}\right)$ para a variável concentração de AGVs maiores $\left(\mathrm{C}_{2}+\mathrm{C}_{3}+\mathrm{C}_{4}\right)$ no líquido ruminal $(\mathrm{mM})$, em diferentes horas de amostragem no experimento com bovinos

Tabela 13 - Efeitos da proporção de concentrados (Con) e dose de monensina (Mon) sobre as porcentagens molares de acetato (\% molar) no líquido ruminal, em diferentes horas de amostragem, coeficientes de variação $(\mathrm{CV})$ e probabilidades estatísticas no experimento com bovinos

Tabela 14 - Coeficientes de regressão e de determinação $\left(R^{2}\right)$ para a variável porcentagem molar de acetato (\% molar) no líquido ruminal, em diferentes horas de amostragem no experimento com bovinos 
Tabela 15 - Efeitos da proporção de concentrados (Con) e dose de monensina (Mon) sobre as porcentagens molares de propionato (\% molar) no líquido ruminal, em diferentes horas de amostragem, coeficientes de variação $(\mathrm{CV})$ e probabilidades estatísticas no experimento com bovinos

Tabela 16 - Coefícientes de regressão e de determinação $\left(R^{2}\right)$ para a variável porcentagem molar de propionato (\% molar) no líquido ruminal, em diferentes horas de amostragem no experimento com bovinos

Tabela 17 - Efeitos da proporção de concentrados (Con) e dose de monensina (Mon) sobre as porcentagens molares de butirato (\% molar) no líquido ruminal, em diferentes horas de amostragem, coeficientes de variação $(\mathrm{CV})$ e probabilidades estatísticas no experimento com bovinos

Tabela 18 - Coeficientes de regressão e de determinação $\left(R^{2}\right)$ para a variável porcentagem molar de butirato (\% molar) no líquido ruminal, em diferentes horas de amostragem no experimento com bovinos 
Tabela 19 - Efeitos da proporção de concentrados (Con) e dose de monensina (Mon) sobre as relações acetato:propionato (com base na \% molar) no líquido ruminal, em diferentes horas de amostragem, coeficientes de variação $(\mathrm{CV})$ e probabilidades estatísticas no experimento com bovinos

Tabela 20 - Coeficientes de regressão e de determinação $\left(\mathrm{R}^{2}\right)$ para a variável relação acetato:propionato (com base na \% molar) no líquido ruminal, em diferentes horas de amostragem no experimento com bovinos ... 078

Tabela 21 - Efeitos da proporção de concentrados (Con) e dose de monensina (Mon) sobre as concentrações ruminais de nitrogênio amoniacal $(\mathrm{mg} / \mathrm{dl})$, em diferentes horas de amostragem, coeficientes de variação $(\mathrm{CV})$ e probabilidades estatísticas no experimento com bovinos

Tabela 22 - Coeficientes de regressão e de determinação $\left(\mathrm{R}^{2}\right)$ para a variável concentração ruminal de nitrogênio amoniacal (mg/dl), em diferentes horas de amostragem no experimento com bovinos

Tabela 23 - Composição bromatológica do feno utilizado no ensaio de digestibilidade ruminal in situ, com base na matéria seca 
Tabela 24 - Efeitos da proporção de concentrados (Con) e dose de monensina (Mon) sobre a digestibilidade ruminal in situ da MS do feno de Tifton 85 , coeficientes de variação $(\mathrm{CV})$ e probabilidades estatísticas no experimento com bovinos

Tabela 25 - Coeficientes de regressão e de determinação $\left(R^{2}\right)$ para os parâmetros da variável digestibilidade ruminal in situ da MS do feno de Tifton 85 obtidos no experimento com bovinos

Tabela 26 - Efeitos da proporção de concentrados (Con) e dose de monensina (Mon) sobre a digestibilidade ruminal in situ da FDN do feno de Tifton 85 , coeficientes de variação $(\mathrm{CV})$ e probabilidades estatísticas no experimento com bovinos

Tabela 27 - Coeficientes de regressão e de determinação $\left(R^{2}\right)$ para os parâmetros da variável digestibilidade ruminal in situ da FDN do feno de Tifton 85 obtidos no experimento com bovinos

Tabela 28 - Efeitos da proporção de concentrados (Con) e dose de monensina (Mon) sobre a digestibilidade ruminal in situ da FDA do feno de Tifton 85 , coeficientes de variação $(\mathrm{CV})$ e probabilidades estatísticas no experimento com bovinos 099 
Tabela 29 - Coeficientes de regressão e de determinação $\left(R^{2}\right)$ para os parâmetros da variável digestibilidade ruminal in situ da FDA do feno de Tifton 85 obtidos no experimento com bovinos

Tabela 30 - Efeitos da proporção de concentrados (Con) e dose de monensina (Mon) sobre a digestibilidade ruminal in situ da MS do farelo de soja, coeficientes de variação $(\mathrm{CV})$ e probabilidades estatísticas no experimento com bovinos

Tabela 31 - Coeficientes de regressão e de determinação $\left(R^{2}\right)$ para os parâmetros da variável digestibilidade ruminal in situ da MS do farelo de soja obtidos no experimento com bovinos

Tabela 32 - Efeitos da proporção de concentrados (Con) e dose de monensina (Mon) sobre a digestibilidade ruminal in situ da PB do farelo de soja, coeficientes de variação $(\mathrm{CV})$ e probabilidades estatísticas no experimento com bovinos

Tabela 33- Coeficientes de regressão e de determinação $\left(R^{2}\right)$ para os parâmetros da variável digestibilidade ruminal in situ da PB do farelo de soja obtidos no experimento com bovinos 
Tabela 34 - Efeitos da proporção de concentrados (Con) e dose de monensina (Mon) sobre a digestibilidade ruminal in situ da MS dos grãos de milho moído, coeficientes de variação $(\mathrm{CV})$ e probabilidades estatísticas no experimento com bovinos

Tabela 35 - Coeficientes de regressão e de determinação $\left(R^{2}\right)$ para os parâmetros da variável digestibilidade ruminal in situ da MS dos grãos de milho moído obtidos no experimento com bovinos

Tabela 36 - Efeitos da proporção de concentrados (Con) e dose de monensina (Mon) sobre a digestibilidade aparente (em \%) da MS da dieta e suas frações, coeficientes de variação $(\mathrm{CV})$ e probabilidades estatísticas no experimento com bovinos

Tabela 37 - Coeficientes de regressão e de determinação $\left(R^{2}\right)$ para as variáveis digestibilidade aparente (em \%) da MS da dieta e suas frações no experimento com bovinos

Tabela 38 - Efeitos da proporção de concentrados (Con) e dose de monensina (Mon) sobre a digestibilidade aparente (em \%) da MS da dieta e suas frações, quando corrigidas para o consumo diário de matéria seca $(\mathrm{kg} / \mathrm{dia})$, coeficientes de variação $(\mathrm{CV})$ e probabilidades estatísticas no experimento com bovinos 
Tabela 39 - Coeficientes de regressão e de determinação $\left(R^{2}\right)$ para as variáveis digestibilidade aparente (em \%) da MS da dieta e suas frações, quando corrigidas para o consumo diário de matéria seca $(\mathrm{kg} / \mathrm{dia})$, no experimento com bovinos

Tabela 40 - Efeitos da proporção de concentrados (Con) e dose de monensina (Mon) sobre a digestibilidade aparente (em \%) da MS da dieta e suas frações, coeficientes de variação $(\mathrm{CV})$ e probabilidades estatísticas no experimento com ovinos

Tabela 41 - Coeficientes de regressão e de determinação $\left(R^{2}\right)$ para as variáveis digestibilidade aparente (em \%) da MS da dieta e suas frações no experimento com ovinos

Tabela 42 - Efeitos da proporção de concentrados (Con) e dose de monensina (Mon) sobre a digestibilidade aparente (em \%) da MS da dieta e suas frações, quando corrigidas para o consumo diário de matéria seca $(\mathrm{kg} /$ dia $)$, coeficientes de variação $(\mathrm{CV})$ e probabilidades estatísticas no experimento com ovinos

Tabela 43 - Coeficientes de regressão e de determinação $\left(R^{2}\right)$ para as variáveis digestibilidade aparente (em \%) da MS da dieta e suas frações, quando corrigidas para o consumo diário de matéria seca $(\mathrm{kg} / \mathrm{dia})$, no experimento com ovinos 
Tabela 44 - Efeitos da proporção de concentrados (Con) e dose de monensina (Mon) sobre a digestibilidade in vitro do farelo de soja (em \%) em diferentes horas de amostragem, coeficientes de variação $(\mathrm{CV})$ e probabilidades estatísticas no experimento com bovinos

Tabela 45 - Coeficientes de regressão e de determinação $\left(R^{2}\right)$ para a variável digestibilidade in vitro do farelo de soja (em \%) em diferentes horas de amostragem no experimento com bovinos

Tabela 46 - Efeitos da proporção de concentrados (Con) e dose de monensina (Mon) sobre a retenção nitrogenada, expressa em gramas de nitrogênio por animal por dia $(\mathrm{RNg})$ ou porcentagem em relação ao nitrogênio absorvido (RN\%), coeficientes de variação (CV) e probabilidades estatísticas no experimento com ovinos

Tabela 47 - Coeficientes de regressão e de determinação $\left(R^{2}\right)$ para a variável retenção nitrogenada, expressa em gramas de nitrogênio por animal por dia $(\mathrm{RNg})$ ou porcentagem do nitrogênio retido em relação ao nitrogênio absorvido (RN\%), no experimento com ovinos 
Página

Tabela 48 - Efeitos da proporção de concentrados (Con) e dose de monensina (Mon) sobre o volume líquido ruminal (VL), em litros, volume líquido como porcentagem do peso vivo (VL/PV), em porcentagem, taxa de passagem (TP), em porcentagem por hora, fluxo de passagem de líquidos por dia (FL), em litros, fluxo líquido por quilo de matéria seca consumida por dia (FL/CMS), em litros, coefícientes de variação $(\mathrm{CV})$ e probabilidades estatísticas no experimento com bovinos

Tabela 49 - Coeficientes de regressão e de determinação $\left(\mathrm{R}^{2}\right)$ para as variáveis volume líquido ruminal (VL), em litros, volume líquido como porcentagem do peso vivo (VL/PV), em porcentagem, taxa de passagem (TP), em porcentagem por hora, fluxo de passagem de líquidos por dia (FL), em litros, fluxo líquido por quilo de matéria seca consumida por dia (FL/CMS), em litros, obtidos no experimento com bovinos 


\section{LISTA DE FIGURAS}

Página

Figura 01 - Efeitos da proporção de concentrados (\% da dieta) e dose de monensina (mg/animal/dia) sobre consumo diário de matéria seca por quilo de peso metabólico $\left(\mathrm{CMS} / \mathrm{kgP}^{0,75}\right)$, em gramas, no experimento com bovinos

Figura 02 - Efeitos da proporção de concentrados (\% da dieta) e dose de monensina (mg/animal/dia) sobre o $\mathrm{pH}$ médio do líquido ruminal, entre as diferentes horas de amostragem, obtidos no experimento com bovinos

Figura 03 - Efeitos da proporção de concentrados (\% da dieta) e dose de monensina (mg/animal/dia) sobre a porcentagem molar de acetato média (\% molar) no líquido ruminal, entre as diferentes horas de amostragem, obtidos no experimento com bovinos

Figura 04 - Resposta da porcentagem molar de acetato média (unidades de \% molar) no liquido ruminal ao efeito da administração de monensina (mg/animal/dia) em diferentes proporções de concentrados na dieta, obtida no experimento com bovinos 
Figura 05 - Efeitos da proporção de concentrados (\% da dieta) e dose de monensina ( $\mathrm{mg} / \mathrm{animal} / \mathrm{dia})$ sobre a porcentagem molar de propionato média (\% molar) no líquido ruminal, entre as diferentes horas de amostragem, obtidos no experimento com bovinos

Figura 06 - Resposta da porcentagem molar de propionato média (unidades de \% molar) no líquido ruminal ao efeito da administração de monensina (mg/animal/dia) em diferentes proporções de concentrados na dieta, obtida no experimento com bovinos

Figura 07 - Efeitos da proporção de concentrados (\% da dieta) e dose de monensina (mg/animal/dia) sobre a porcentagem molar de butirato média (\% molar) no líquido ruminal, entre as diferentes horas de amostragem, obtidos no experimento com bovinos

Figura 08 - Resposta da porcentagem molar de butirato média (unidades de \% molar) no líquido ruminal ao efeito da administração de monensina (mg/animal/dia) em diferentes proporções de concentrados na dieta, obtida no experimento com bovinos

Figura 09 - Efeitos da proporção de concentrados (\% da dieta) e dose de monensina (mg/animal/dia) sobre a relação acetato:propionato média (com base na \% molar) no líquido ruminal, entre as diferentes horas de amostragem, obtidos no experimento com bovinos 
Figura 10 - Resposta da relação acetato:propionato média (unidades de relação acetato:propionato) no líquido ruminal ao efeito da administração de monensina (mg/animal/dia) em diferentes proporções de concentrados na dieta, obtida no experimento com bovinos

Figura 11 - Efeitos da proporção de concentrados (\% da dieta) e dose de monensina (mg/animal/dia) sobre a concentração ruminal de nitrogênio amoniacal (mg/dl) 4 horas após a alimentação, obtidos no experimento com bovinos

Figura 12 - Efeitos da proporção de concentrados (\% da dieta) e dose de monensina (mg/animal/dia) sobre a degradabilidade efetiva da FDN do feno de Tifton 85 , quando calculada para taxa de passagem de 0,05 (De 5\%), obtidos no experimento com bovinos

Figura 13 - Efeitos da proporção de concentrados (\% da dieta) e dose de monensina ( $\mathrm{mg} / \mathrm{animal} / \mathrm{dia})$ sobre a degradabilidade efetiva da MS dos grãos de milho moídos, quando calculada para taxa de passagem de 0,05 (De 5\%), obtidos no experimento com bovinos

Figura 14 - Efeitos da proporção de concentrados (\% da dieta) e dose de monensina (mg/animal/dia) sobre a digestibilidade aparente (em \%) da MS da dieta, quando corrigida para o consumo diário de matéria seca $(\mathrm{kg} / \mathrm{dia})$, obtidos no experimento com bovinos 
Figura 15 - Efeitos da proporção de concentrados (\% da dieta) e dose de monensina (mg/animal/dia) sobre a digestibilidade aparente (em \%) da PB da dieta, quando corrigida para o consumo diário de matéria seca $(\mathrm{kg} / \mathrm{dia})$, obtidos no experimento com bovinos

Figura 16 - Efeitos da proporção de concentrados (\% da dieta) e dose de monensina (mg/animal/dia) sobre o NDT (em \%) da dieta, quando corrigido para o consumo diário de matéria seca $(\mathrm{kg} / \mathrm{dia})$, obtidos no experimento com bovinos

Figura 17 - Efeitos da proporção de concentrados (\% da dieta) e dose de monensina (mg/animal/dia) sobre a digestibilidade aparente (em \%) da FDA da dieta, quando corrigida para o consumo diário de matéria seca $(\mathrm{kg} / \mathrm{dia})$, obtidos no experimento com bovinos

Figura 18- Efeitos da proporção de concentrados (\% da dieta) e dose de monensina (mg/animal/dia) sobre a digestibilidade aparente (em \%) da PB da dieta, quando corrigida para o consumo diário de matéria seca $(\mathrm{kg} / \mathrm{dia})$, obtidos no experimento com ovinos

Figura 19 - Efeitos da proporção de concentrados (\% da dieta) e dose de monensina ( $\mathrm{mg} /$ animal/dia) sobre a digestibilidade aparente (em \%) da FB da dieta, quando corrigida para o consumo diário de matéria seca $(\mathrm{kg} / \mathrm{dia})$, obtidos no experimento com ovinos 
Página

Figura 20 - Efeitos da proporção de concentrados (\% da dieta) e dose de monensina (mg/animal/dia) sobre a digestibilidade in vitro do farelo de soja (em \%) com inóculo coletado 3 horas após a alimentação, obtidos no experimento com bovinos

Figura 21 - Efeitos da proporção de concentrados (\% da dieta) e dose de monensina $(\mathrm{mg} / \mathrm{animal} / \mathrm{dia})$ sobre a retenção nitrogenada, expressa em porcentagem de nitrogênio retido em relação ao nitrogênio absorvido (RN\%), obtidos no experimento com ovinos 


\section{LISTA DE ABREVIATURAS}

$a$ - interseção da curva no tempo zero (fração rapidamente degradável)

AGVs - ácidos graxos voláteis

$b \quad$ - fração potencialmente degradável

c $\quad$ - taxa de degradação

$\mathrm{C}_{2}$ - acetato

$\mathrm{C}_{3}$ - propionato

$\mathrm{C}_{4} \quad$ - butirato

CMS - consumo de matéria seca

Con - proporção de concentrados

Con $_{D}$ - efeito de desvio da linearidade da proporção de concentrados

$\mathrm{Con}_{\mathrm{L}} \quad$ - efeito linear da proporção de concentrados

CV - coeficientes de variação

De ou $P$ - degradabilidade efetiva

DIVMS - digestibilidade in vitro da matéria seca

Dp - degradabilidade potencial $(a \div b)$

e - logaritmo natural

EB - energia bruta

EE - extrato etéreo

ENN - extrativo não nitrogenado

FB - fibra bruta

FDA - fibra em detergente ácido

FDN - fibra em detergente neutro

FL - fluxo de passagem de líquidos por dia

FL/MS - fluxo de liquidos por quilo de matéria seca consumida por dia

FS - farelo de soja 
h $\quad$ - hora

$k \quad$ - taxa de saída do rúmen em porcentagem por hora

$\mathrm{kgPV}$ - quilos de peso vivo

$\mathrm{kgP}^{0,75}$ - quilos de peso metabólico

Mon - dose de monensina

Mon $_{D}$ - efeito de desvio da linearidade da dose de monensina

$\mathrm{Mon}_{\mathrm{L}} \quad$ - efeito linear da dose de monensina

MM - matéria mineral

$\mathrm{mM}$ - solução milimolar

MO - matéria orgânica

MS - matéria seca

$\mathrm{N}$ - solução normal

$\mathrm{N}-\mathrm{NH}_{3}$ - nitrogênio amoniacal

NDT - nutrientes digestíveis totais

$p \quad$ - quantidade de alimento degradado ao tempo $(t)$,

PB - proteína bruta

PDR - proteína degradável ruminal

PEG - polietilenoglicol

PND - proteína não degradável

$\mathrm{R}^{2} \quad$ - coeficiente de determinação

$\mathrm{RNg}$ - retenção nitrogenada expressa em gramas de N/animal/dia

RN\% - retenção nitrogenada expressa em \% do $\mathrm{N}$ absorvido

$t \quad$ - tempo

TP - taxa de passagem de líquidos

VL - volume líquido ruminal

vs. - versus 


\title{
EFEITOS DOS NÍVEIS DE MONENSINA E PROPORÇÕES \\ VOLUMOSOS/CONCENTRADOS NA RAÇÃO SOBRE A \\ UTILIZAÇÃO DOS ALIMENTOS E PARÂMETROS \\ DA FERMENTAÇÃO RUMINAL EM \\ ANIMAIS RUMINANTES
}

\author{
Autor: PAULO HENRIQUE MAZZA RODRIGUES \\ Orientador: Prof. Dr. WILSON ROBERTO SOARES MATTOS
}

\section{RESUMO}

Foram objetivos de presente estudo avaliar os efeitos de doses de monensina sobre a fermentação ruminal e digestão ruminal e total em ruminantes submetidos a diferentes dietas. No experimento um, nove vacas secas dotadas de fistulas ruminais foram distribuídas em um delineamento inteiramente casualizado, com 3 subperíodos, em um arranjo fatorial de tratamentos $3 \times 3$, correspondentes a zero, 150 ou $300 \mathrm{mg}$ de monensina sódica por animal e por dia e $25 \%, 50 \%$ ou $75 \%$ de concentrados na dieta, composta por mistura de concentrados, a base de milho e farelo de soja, e feno de Tifton 85. Os sub-períodos tiveram duração total de 21 dias, sendo os 16 primeiros dias destinados à adaptação dos animais à dieta. A depressão causada pela monensina sobre consumo de matéria seca foi maior nas dietas mistas ( $50 \%$ de concentrados). Para as variáveis $\mathrm{pH}$, proporção molar de AGVs e concentração de nitrogênio amoniacal no conteúdo ruminal, coletadas às $0,2,4,6,8,10$ e 12 horas após a alimentação, bem como para a digestão ruminal in situ da fibra do feno e da MS dos grãos de milho, a resposta a doses altas de monensina foi maior em dietas com baixos níveis em fibra, enquanto que a resposta a doses baixas do produto foi maior em dietas com altos níveis em fibra. Excetuando a digestibilidade ruminal da fibra, a monensina melhorou todos estes 
parâmetros. A monensina aumentou a digestibilidade ruminal in situ (técnica dos sacos de náilon) e in vitro (com inóculo dos animais tratados) da proteína bruta do farelo de soja, aumentou a digestibilidade total da matéria seca, da proteína bruta, da fibra bruta $\mathrm{e}$ os nutrientes digestíveis totais da dieta, avaliadas através do marcador óxido crômico, e diminuiu a concentração total dos AGVs, independentemente do nível de fibra utilizado. A monensina não afetou a digestibilidade total do extrato etéreo e dos extrativos não nitrogenados, bem como o volume líquido e a taxa de passagem de líquidos pelo rúmen, qualquer que fosse a dieta utilizada. No experimento dois, dezoito cameiros machos e castrados foram distribuídos em um delineamento inteiramente casualizado com um arranjo fatorial de tratamentos $2 \times 3$, correspondentes a zero ou $40 \mathrm{mg}$ de monensina sódica por animal e por dia e $25 \%, 50 \%$ ou $75 \%$ de concentrados na dieta. Esta possuia composição semelhante à das vacas. A monensina aumentou a digestibilidade total da proteína bruta, avaliada através de coleta total de fezes, independentemente do nível de fibra utilizado. A monensina interagiu com o nível de concentrados da dieta para a digestibilidade total da fibra bruta e retenção nitrogenada, sendo as melhores respostas obtidas na dieta predominantemente concentrada e piores na dieta mista. Este produto não alterou o consumo de matéria seca, a digestibilidade total da matéria seca, dos extrativos não nitrogenados, do extrato etéreo, da fibra em detergente ácido, da fibra em detergente neutro, da energia bruta e os nutrientes digestíveis totais em qualquer dieta. Concluíu-se que a resposta à monensina pode ser maior ou em dietas concentradas ou em dietas volumosas, dependendo da dose do produto utilizada. 


\title{
EFFECTS OF MONENSIN LEVEL AND ROUGHAGE/CONCENTRATE RATIO ON DIGESTIBILITY OF NUTRIENTES AND RUMINAL FERMENTATION IN RUMINANTS
}

\author{
Author: PAULO HENRIQUE MAZZA RODRIGUES \\ Adviser: Prof. Dr. WILSON ROBERTO SOARES MATTOS
}

\section{SUMMARY}

The objective of this study was to evaluate the effects of monensin level on ruminal fermentation and, ruminal and total tract digestibility in ruminants fed with different diets. In trial one, nine rumen-fistulated dry cows were used in a completely random design replicated with three periods to evaluate three monensin levels $(0,150$ and $300 \mathrm{mg} /$ animal/day) and three concentrate levels $(25 \%, 50 \%$ and $75 \%)$ in a $3 \times 3$ factorial arrangement. Twenty-one day subperiods were used, the first sixteen for diet adaptation, constituted by Tifton 85 hay and concentrate mixture. Monensin decreased dry matter intake only in 50\%-concentrate diet. For ruminal $\mathrm{pH}$, molar proportion of volatile fatty acids, and ammonia- $\mathrm{N}$ concentration collected at $0 \mathrm{~h}, 2 \mathrm{~h}, 4 \mathrm{~h}, 6 \mathrm{~h}, 8 \mathrm{~h}, 10 \mathrm{~h}$ and $12 \mathrm{~h}$ after the morning meal, as well as in situ ruminal digestion (nylon bag method) of hay acid detergent fiber and neutral detergent fiber and corn grain dry matter the responses to high levels of monensin were higher in low-forage diets. Responses to low levels of monensin were higher in high-forage diets. Except for in situ ruminal digestion of fiber, monensin improved those parameters. Monensin increased in situ and in vitro (inoculated with rumen fluid of experimental animals) ruminal digestion of soybean meal crude protein, increased total tract digestibility of dry matter, crude protein, crude fiber, and total digestible nutrients and decreased total volatile fatty acids concentrations independent on concentrate level. Monensin suplementation did not influence total tract digestibility of ether extract and nitrogen-free extract, as well as ruminal liquid turnover and ruminal liquid volume. In trial two, 18 wethers were randomly distributed to three 
diets with different concentrate levels $(25 \%, 50 \%$ and $75 \%)$ without (control) or with monensin (40 mg/animal/day). Experimental period extended for twenty-six days, the last five used for feces and urine collection. Diet was similar to the one described in trial one. Monensin increased total tract digestibility of crude protein, independent on concentrate level. There was an interaction between concentrate level and monensin on total tract digestibility of crude fiber and nitrogen balance. The best response to monensin was obtained from the high-concentrate diet and the worst from the 50\%concentrate diet. Monensin supplementation did not influence dry matter intake, total tract digestibility of dry matter, ether extract, nitrogen-free extract, acid detergent fiber, neutral detergent fiber, gross energy and total digestible nutrients in any diet. It was concluded that monensin response can be greater in either high-concentrate or highforage diets depending on its administration level. 


\section{INTRODUÇÃO}

Grande parte do conhecimento atual em nutrição foi adquirido durante o Século XX, podendo este ser considerado o século das descobertas. Durante este período foram descobertas a quase totalidade das vitaminas, o papel dos aminoácidos, dos ácidos graxos essenciais e dos macro e microelementos. É bastante provável que todos os nutrientes essenciais importantes já tenham sidos descobertos, uma vez que é possivel manter os animais domésticos através de um ciclo reprodutivo completo, quando alimentados com dietas purificadas, contendo todos os nutrientes importantes conhecidos (Church \& Pond, 1988).

Na nutrição de ruminantes, durante muito tempo procurou-se manipular a fermentação ruminal, melhorando sua eficiência, seja através do aumento da produção do ácido propiônico, da diminuição da metanogênese ou da diminuição da proteólise e deaminação de proteínas no rúmen. Inicialmente este objetivo foi perseguido apenas através da manipulação da dieta. Entretanto, a descoberta de compostos químicos ativos no rúmen abriu grandes perspectivas nessa área das ciências agrícolas (Bergen \& Bates, 1984).

Uma classe desses compostos que vem obtendo considerável sucesso como aditivos alimentares são os chamados antibióticos ionóforos polieter carboxílicos, os quais são substâncias produzidas por várias cepas de Streptomyces sp. Entre elas incluem-se a monensina, lasalocida, salinomicina, narasina e outras. Por definição, ionóforos são moléculas de baixo peso molecular capazes de interagir estequiometricamente com íons metálicos, servindo como transportadores mediante os 
quais estes íons podem ser levados através de uma membrana lipídica bimolecular (Ovchinnikov, 1979).

Tais quais os nutrientes essenciais, as respostas alcançadas com a utilização dos ionóforos são bastantes variáveis, fenômeno que pode ser explicado, em parte, pelas diferentes condições experimentais (Galloway et al., 1993).

Embora o Século XX tenha trazido a luz o conhecimento de um grande número nutrientes, hormônios, e outros compostos que afetam o desempenho animal, ainda muito pouco se sabe como os diversos fatores interagem entre si. Como um afeta a resposta do outro. É imperativo ao Século XXI desvendar, não mais as moléculas, mas como umas afetam a resposta de outras, perante os organismos vivos. 


\section{OBJETIVOS}

Foram objetivos do presente trabalho estudar os efeitos da aplicação de diferentes dosagens de monensina sobre: consumo de alimentos, alguns parâmetros da fermentação ruminal, tais como $\mathrm{pH}$ ruminal, produção de ácidos graxos voláteis e concentrações ruminais de nitrogènio amoniacal, parâmetros de dinâmica líquida ruminal, digestibilidade ruminal in situ da proteina bruta e fibra de alimentos concentrados ou volumosos e digestibilidade in vivo da matéria seca e nutrientes da dieta, considerando dietas com diferentes proporções entre volumosos e concentrados, uma vez que esses dois fatores (dosagem do produto e proporção de fibra na dieta) podem ser considerados como alguns dos mais importantes em alterar a resposta à utilização de ionóforos. Soma-se aos objetivos deste trabalho estudar as variações dos efeitos deste aditivo ao longo do dia, em decorrència de possíveis variações nas suas concentrações ruminais, sobre a utilização da proteína. 


\section{REVISÃO DE LITERATURA}

\subsection{Modos de ação dos ionóforos}

Conforme proposto por Schelling (1984), pode-se diferenciar os modos de ação dos ionóforos em dois tipos: um básico, ocorrendo na membrana celular dos microorganismos ruminais, e outro sistêmico, composto por sete categorias de ação, resultantes da alteração do metabolismo das bactérias do rúmen e afetando a resposta animal. Desta forma, os ionóforos possuem a capacidade de aumentar a eficiência do metabolismo energético e protéico no rúmen, no animal e diminuem a incidência de distúrbios digestivos (Bergen \& Bates, 1984).

\subsubsection{Tipo básico}

O modo básico de ação dos ionóforos parece resultar de interferência no fluxo iônico normal através da membrana dos microorganismos e dissipação do gradiente de prótons e cátions, sistemas estes responsáveis pelo aporte de aminoácidos, açúcares e outros íons contra um gradiente de concentração (Bergen \& Bates, 1984). Como esta interferência pode ser compensada as custas de ATP, as células que possuem um sistema de transporte de elétrons acoplado à extrusão de prótons e/ou síntese de ATP terão melhores condições de sobreviver, apesar das maiores exigências em energia, em detrimento das células que dependem da fosforilação em nível de substrato, via ATPase (Bergen \& Bates, 1984). 
De acordo, ainda, com Ovchinnikov (1979), para desempenhar sua função eficientemente, os ionóforos devem formar complexos suficientemente estáveis com cátions e serem capazes de se dividir entre a superficie e o interior da membrana, ou seja, devem ter propriedades lipofilica e de superficie-ativa. Quando complexados com o cátion, devem ser altamente lipofilicos, de modo a passarem através da membrana, permitindo que a transferência de um cátion ocorra a uma taxa suficientemente alta, o que pode ser satisfeito com rearranjos conformacionais da molécula, devido à mudanças na sua estrutura tri-dimensional.

Os ionóforos exercem ação seletiva sobre as bactérias, de forma que as Gram negativas sobrevivem graças ao sistema enzimático fumarato-redutase, que acopla o transporte de elétrons à extrusão de prótons via membrana citoplasmática, ser mais prevalente nestes microorganismos (Chen \& Wolin, 1979). Diferentemente, as Gram positivas possuem capacidade restrita de gerar um gradiente de prótons e, portanto, dependem de um gasto direto de ATP para promover o transporte ativo através da membrana (Hefner \& Harold, 1982). É genericamente aceito que os efeitos dos ionóforos na fermentação ruminal são devidos às mudanças na microflora do rúmen (Chen \& Wolin, 1979). Outros trabalhos demonstraram que esses efeitos decorrem somente de alterações nas vias metabólicas preferenciais das bactérias do pró-ventrículo (Richardson et al., 1976).

\subsubsection{Tipo sistêmico}

Quanto ao tipo sistèmico de ação, é constituído por sete formas resultantes do tipo básico (Schelling, 1984) e listados da seguinte maneira: modificação na produção de ácidos graxos voláteis; modificação no consumo de alimentos; modificação na produção de gases; modificações nas digestibilidades; modificação na utilização da proteína; modificações no enchimento e taxa eferente de passagem ruminais e outros. 


\subsubsection{Produção de AGVs}

Classicamente os ionóforos são conhecidos por alterarem a proporção molar de ácidos graxos voláteis (AGVs) produzidos no rúmen, devido ao aumento do ácido propiônico $\left(\mathrm{C}_{3}\right)$ em detrimento dos ácidos acético $\left(\mathrm{C}_{2}\right)$ e/ou butírico $\left(\mathrm{C}_{4}\right)$, geralmente sem causar grandes alterações sobre a produção total de AGVs.

Vários fatores podem alterar os efeitos dos ionóforos sobre os AGVs, tais como: nível de fibra, energia, protéína, período de adaptação, momento da coleta, espécie animal, tipo de ionóforo utilizado e outros.

A diferença na proporção volumoso:concentrados, ou no teor de fibra na dieta, parece alterar a magnitude da resposta encontrada na proporção molar de AGVs ocasionada pelos ionóforos, apesar dos resultados serem controversos. Thomton \& Owens (1981) observaram que a monensina aumentou a proporção molar de propionato em $65,6 \%$ em uma dieta com altos níveis de fibra (40\% de FDA) e somente $38,6 \%$ quando a mesma possuía baixos níveis (12\% de FDA). A diminuição na proporção molar de acetato foi semelhante entre as duas (11,7\% a 10,8\%, respectivamente) e não foram observadas alterações na concentração total de AGVs e proporção molar de butirato em qualquer das dietas. Da mesma forma, Da Silva (1990) somente observou efeito da lasalocida sobre a proporção molar de ácidos graxos voláteis, com aumento do propiônico e diminuição do acético e butírico, após a associação deste produto com bicarbonato de sódio na dieta de vacas alimentadas com $40 \%$ de concentrados. Tais dados são compatíveis com um estudo in vitro, onde testou-se o efeito da monensina em dietas com $0 \%, 50 \%$ e $90 \%$ de concentrados. Neste estudo observou-se que a monensina aumentou a concentração de propionato em $17,1 \%$ e $47,9 \%$ para as dietas contendo $0 \%$ e $50 \%$ de concentrados, respectivamente, mas não alterou significativamente esta variável quando o meio continha $90 \%$ de concentrados (Garcia-Lopez et al., 1996). Esses últimos autores reconheceram a dose baixa utilizada como a causa da falta de efeito na dieta concentrada. 
Dados contrários foram obtidos em outro estudo in vitro onde foram utilizados inóculos de animais alimentados com dieta ricas em grãos ou em volumosos (Richardson et al., 1976). Neste experimento, quando utilizou-se inóculo de animais alimentados com dieta predominantemente concentrada, diferentes concentrações de monensina diminuíram a produção de acetato, butirato, valerato e isovalerato e aumentaram a de propionato. Ao utilizar inóculo de animais submetidos à dieta predominantemente volumosa, esses efeitos foram observados somente com as concentrações mais elevadas do produto. In vivo, Ramanzin et al. (1997) observaram maiores efeitos da monensina sobre a proporção molar de propionato em vacas leiteiras submetidas a dietas com $50 \%$ de concentrados (aumento de $26,7 \%$ ) do que quando estas recebiam dietas com apenas $30 \%$ de concentrados (aumento de 8,9\%). Mesmo em novilhos, Zinn et al. (1994) observaram efeitos positivos da monensina em aumentar a proporção molar de propionato somente nas dietas com apenas $10 \%$ de volumosos (aumento de 9,4\%), mas observaram diminuição deste parâmetro quando a dieta possuía $20 \%$ de volumosos (diminuição de $5,5 \%$ ).

Ao administrar lasalocida a bovinos recebendo $40 \%$ ou $70 \%$ de volumoso na dieta, Rodrigues (1996) observou interação entre a lasalocida e o teor de fibra da dieta, de forma que a proporção molar de propionato foi maior e a relação acetato:propionato menor nas rações com $40 \%$ de volumoso, quando comparadas àquelas com $70 \%$, na presença de lasalocida, mas não na sua ausência, indicando que este ionóforo tenha causado alterações nas proporções molares de AGVs somente em dietas mais concentradas. Contrariamente, Van Maanen et al. (1978), ao estudar os efeitos da adição da monensina na dieta de novilhos recebendo proporções de volumoso de $20 \%$ e $70 \%$, observaram que este aditivo aumentou as reservas ruminais e a taxa de produção de propionato em $79,1 \%$ e $62,84 \%$, respectivamente, diminuiu a proporção molar de butirato em $14,53 \%$, para ambas as dietas, mas não alterou a proporção molar de propionato ou acetato e registraram que todos os efeitos observados não dependeram do tipo da dieta utilizada. 
A demonstração de que a monensina cataliza o efluxo de potássio em bactérias ruminais sensíveis a ela (Russell \& Strobel, 1989; Lana \& Russell, 1996) e que essas bactérias sensíveis à monensina se tornam mais resistentes ao produto quando as concentrações externas de potássio são altas (Dawson \& Boling, 1987), faz suspeitar do possível confundimento entre efeito do nível de fibra ou nível de potássio sobre a grandeza das respostas obtidas com o uso de ionóforos.

Um fato que tem intrigado os pesquisadores é como os ionóforos alteram a proporção molar de AGVs e quais as conseqüências disto. Segundo Chen \& Wolin (1978), estes efeitos são decorrentes da ação inibitória sobre bactérias produtoras de formato e hidrogênio e estimulatória sobre aquelas produtoras de succinato e propionato, fenômeno, este, que é duplamente vantajoso em termos metabólicos, já que a produção de propionato é energeticamente mais eficiente que a de acetato (Hungate, 1966; Chalupa, 1977) e pelo fato que a utilização do propionato, nos tecidos, também ser mais eficiente que do acetato (Smith, 1971).

Entretanto, Raun et al. (1976) notaram que a alteração na proporção molar de AGVs com a utilização de ionóforos poderia ser responsável por um aumento de $3,0 \%$ a 6,0\% na energia metabolizável disponivel para o animal, apesar dos animais terem ganhado mais peso (até 11,0\%) e aumentado a eficiência de utilização dos alimentos (até 17,0\%) mais do que o esperado. Este fato levou estes pesquisadores a concluírem que o aumento na disponibilidade de energia não é o único benefício alcançado com a utilização de ionóforos, sendo que o aumento do propionato poderia estar, ainda, relacionado a menor incremento calórico (Smith, 1971), proteção de aminoácidos normalmente usados na gliconeogênese (Funk et al., 1986; Beede et al., 1986b) e outros fatores.

Experimentos realizados in vivo não observaram efeitos dos ionóforos sobre a concentração total ou sobre a proporção molar de AGVs dosados no líquido ruminal. Baile et al. (1979) não observaram qualquer efeito significativo da monensina sobre a proporção molar de AGVs, seja em novilhos submetidos a dietas predominantemente volumosa $(92 \%$ de volumoso) ou concentrada $(85 \%$ de 
concentrados), bem como Fredrickson et al. (1993), ao administrarem bolus de liberação lenta de monensina a novilhos em regime de pastejo, Green et al. (1999), ao utilizarem o mesmo dispositivo em vacas leiteiras primíparas e multíparas recém-paridas, e Beede et al. (1986a), ao alimentarem vacas leiteiras com uma dieta com $45 \%$ de volumoso suplementada com lasalocida.

Darden et al. (1985) registraram que os ionóforos não causaram alterações na concentração total ou proporção molar de AGVs, quando alimentaram novilhos com níveis de $70 \%$ de concentrados na dieta, explicando esses resultados pelo fato dos animais terem recebido 12 refeições por dia, em intervalos de duas horas cada, o que pode ter causado um consumo de lasalocida pequeno para permitir que o limiar mínimo de concentração da droga no rúmen fosse atingido para alterar a fermentação. Em contrapartida Yang \& Russell (1993) observaram efeitos da monensina, mesmo com alimentação a cada 2 horas.

Jacques et al. (1987) não observaram efeitos da aplicação de lasalocida sobre a concentração total de AGVs ou suas proporções molares em novilhos em pastejo, explicando seus resultados pela baixa qualidade das pastagens utilizadas, enquanto que Morris et al. (1990) registraram que a falta de resposta observada em novilhos alimentados com dieta composta de $90 \%$ de concentrados era devido ao fato da dieta já ter proporcionado altos níveis de propionato, da mesma forma que Zinn (1987), o qual não observou efeito significativo da lasalocida ou monensina mais tilosina em um experimento onde a principal fonte de energia utilizada era composta de amido de alta digestibilidade.

\subsubsection{Consumo de alimentos}

Schelling (1984), em extenso trabalho de revisão a respeito da monensina, afirmou que os ionóforos deprimem o consumo voluntário de alimentos na ordem de 10,7\%, quando os animais são alimentados com dietas predominantemente concentradas, mas podem incrementar o consumo em até $15 \%$, quando em condições de 
pastejo. Rogers \& Davis (1982) explicaram que a diminuição no consumo era provavelmente devido ao aumento do tempo de retenção da matéria seca no rúmen, enquanto que há a possibilidade deste efeito ser devido à ação do ácido propiônico como substância responsável pela regulação da saciedade em ruminantes, a semelhança do que acontece com a glicose sangüínea, que regula o consumo de alimentos em animais monogástricos (Van Soest, 1983). O aumento de consumo em animais recebendo dieta predominantemente volumosa seria explicado pelas alterações na digestibilidade da forragem, já que os níveis de ácido propiônico não seriam suficientes para disparar o gatilho da saciedade nessas dietas (Schelling, 1984). Estes resultados não estão de acordo com as conclusões de Baile et al. (1979) que afirmaram que os ionóforos reduzem o consumo de alimentos em qualquer tipo de dieta, embora com maiores efeitos em dietas predominantemente concentradas.

A afirmação de Baile et al. (1979) foi confirmada por Araujo-Febres \& Fernández (1991) que, ao estudarem os efeitos da monensina em novilhos consumindo dietas com níveis de fibra bruta baixo $(15 \%)$ e alto $(26 \%)$, observaram que a monensina diminuiu o consumo de alimentos em ambas as dietas, porém a queda foi maior para a ração com baixo nível de fibra (25,6\% vs. $11,0 \%)$. Arcaro (1998), estudando os efeitos de três diferentes dosagens de lasalocida sódica em vacas leiteiras submetidas a dietas contendo $30 \%$ ou $50 \%$ de concentrados, observou que este produto diminuiu linearmente o consumo de matéria seca, sendo que esta queda tendeu $(\mathrm{P}=0,08)$ a ser maior nas vacas alimentadas com a dieta mais concentrada, quando comparada com aquelas submetidas à dieta mais volumosa. Ao contrário, McCann et al. (1990), alimentando ovinos com dietas contendo $25 \%, 50 \%$ e $75 \%$ de volumosos, registraram que a monensina diminuiu o consumo em $1,6 \%, 12,3 \%$ e $27,0 \%$, respectivamente.

Baile et al. (1979) afirmaram, ainda, que os ruminantes são capazes de detectar a presença do aditivo comercial que contém a monensina, já que o sabor é suficiente para causar uma aversão imediata ao produto, mas não a monensina sódica propriamente dita, sendo este efeito principalmente observado em dietas predominantemente concentradas. Esta informação é bastante interessante dada a 
afirmação realizada por Chalupa em 1977, mas ainda bastante atual, de que "não existe qualquer dado disponível a respeito dos efeitos dos ionóforos sobre o comportamento alimentar ou se alguma parte da depressão do consumo é devida à aversão condicionada, fatores gustativos ou olfatórios, ou, ainda, mal-estar do animal".

Muitos outros trabalhos não observaram efeitos dos ionóforos sobre o consumo de alimentos, entre eles está o de Rodrigues (1996), utilizando de diferentes proporções volumoso:concentrados para testar o efeito da lasalocida, o de Zinn et al. (1994), utilizando monensina em novilhos submetidos a dietas contendo $10 \%$ ou $20 \%$ de volumosos, e o de Ramanzin et al. (1997), utilizando monensina em vacas alimentadas com dietas contendo 30 ou $50 \%$ de concentrados.

\subsubsection{Produção de metano}

Estudos in vitro (Van Nevel \& Demeyer, 1977; Bartley et al., 1979; Chalupa et al., 1980; Bogaërt et al., 1989; Marounek et al., 1990) e in vivo (Thornton \& Owens, 1981) mostraram que os ionóforos agem sobre os microorganismos ruminais deprimindo a produção de metano, não tendo este efeito resultado em acúmulo de hidrogênio gasoso (Chalupa et al., 1980). Foi também relatada depressão sobre a produção de dióxido de carbono, quando aqueles aditivos foram administrados em altos níveis (Bartley et al., 1979; Chalupa et al., 1980). Já Machado (1988) e Sauer et al. (1997) demonstraram diminuição da produção de metano com o uso da monensina in vitro e in vivo, respectivamente, mas não sobre a produção de dióxido de carbono.

A origem do substrato afetou a resposta dos ionóforos sobre a produção de metano in vitro, mas não in vivo. Em um estudo in vitro, onde alimento concentrado serviu de substrato, a monensina não alterou significativamente a produção de metano. No entanto, quando o substrato utilizado foi uma mistura de celobiose e maltose, a monensina diminuiu a produção desse gás em 14,6\% a 25,0\%. Garcia-Lopez et al. (1996) demonstraram que a monensina diminuiu a produção de metano, em $40 \%$, somente quando o produto foi incubado in vitro com uma dieta contendo $50 \%$ de 
concentrados, mas não quando esta possuía $0 \%$ ou $90 \%$ de grãos. No estudo in vivo a monensina diminuiu as produções de metano em $15,6 \%, 16,5 \%$ e $23,7 \%$ quando novilhos receberam respectivamente níveis de fibra baixo (12\% de FDN), médio ( $27 \%$ de FDN) e alto ( $40 \%$ de FDN), não sendo observada interação entre a monensina e os níveis de fibra na dieta (Thornton \& Owens, 1981). Já Zinn et al. (1994) não observaram alteração da produção ruminal de metano com a administração de monensina, quer a dieta possuísse $10 \%$ ou $20 \%$ de volumosos.

McCaughey et al. (1997) não demonstraram efeito da monensina em diminuir a produção de metano em novilhos sob pastejo.

\subsubsection{Digestibilidade e degradabilidade}

Os ionóforos podem causar pequena à moderada melhora na digestibilidade dos alimentos, dependendo das condições experimentais. Estas condições não estão definidas até o presente momento, podendo sofrer interferência de fatores como consumo de alimentos, enchimento ruminal, taxa de passagem ou outros.

$\mathrm{O}$ aumento da digestão dos alimentos obtidos com o emprego de ionóforos tem sido freqüentemente explicado pelo aumento do tempo de retenção da MS no rúmen decorrente do menor consumo voluntário (Rogers \& Davis, 1982). Entretanto, Branine \& Galyean (1990), ao observarem que a monensina aumentou em $1,4 \%$ a $16,7 \%$ o desaparecimento in situ da MS do alimento em novilhos sob pastejo, provavelmente pelo aumento da degradação da parede celular, explicaram tal fato como sendo decorrente do aumento observado no $\mathrm{pH}$ ruminal e não pela diminuição da taxa de passagem pelo pró-ventrículo, sendo que neste experimento foi observado aumento na taxa de passagem de fluídos.

Dentre os diversos fatores que podem alterar os efeitos dos ionóforos sobre a digestibilidade e degradabilidade dos alimentos encontra-se a proporção de fibra na dieta. Pomar et al. (1989), ao alimentarem bezerros e ovelhas com dietas peletizadas contendo $20 \%, 40 \%$ e $60 \%$ de volumosos de alta e média qualidade, observaram que a 
monensina diminuía a digestibilidade da FDN e FDA em dietas predominantemente concentradas, mas aumentava a digestibilidade destas frações fibrosas em dietas predominantemente volumosas somente em bezerros, mas não em ovelhas, além desses efeitos serem maiores na dieta contendo o volumoso de média qualidade. Os resultados foram explicados por um possível aumento do tempo de retenção da fibra no rúmen, fato esse considerado vantajoso nessas dietas (Lemenager et al., 1978). Entretanto a digestibilidade da MS foi levemente aumentada somente nas rações ricas em volumosos, em contradição com o experimento de McCann et al. (1990) onde, ao alimentarem ovinos com rações contendo $25 \%, 50 \%$ e $75 \%$ de volumosos de baixa qualidade, observou-se que a monensina foi capaz de aumentar a digestibilidade da fibra em detergente neutro e da hemicelulose e apresentou tendência em aumentar a digestibilidade da matéria orgânica a medida em que a proporção de volumosos era diminuída (de 75\% para 25\%). Os resultados de McCann et al. (1990) foram parcialmente confirmados por Araujo-Febres \& Fernández (1991) que observaram ter a monensina aumentado a digestibilidade da matéria seca e da fibra bruta, sendo este aumento maior para as rações pobres em fibra (15\%) quando comparados às ricas em fibra (40\%).

Schelling (1984), em revisão de literatura, concluiu que os efeitos da monensina e lasalocida sobre a digestibilidade dos nutrientes eram ambos negativos e positivos, respectivamente, mas relativamente pequenos. Galloway et al. (1993), pesquisando os efeitos do emprego de níveis baixos e altos de monensina e lasalocida sobre a digestibilidade em bovinos submetidos à dietas volumosas de baixa qualidade, observaram pequeno ou nenhum efeito sobre a digestibilidade da matéria orgânica ou da FDN, para ambos os ionóforos, em doses baixas. Porém, com doses maiores, tanto a monensina como a lasalocida aumentaram a digestibilidade da FDN em até 2,1\% e $4,4 \%$, respectivamente, sendo que uma diferença entre os ionóforos foi sugerida neste trabalho.

Em outros trabalhos não foram observados efeitos dos ionóforos sobre a digestibilidade da MS, conteúdo celular, celulose e hemicelulose em novilhos recebendo 
níveis de fibra baixo (12,0\% de FDN), médio $(27,0 \%)$ e alto $(40,0 \%)$ na dieta adicionada de monensina (Thornton \& Owens, 1981). Zinn et al. (1994) também não observaram efeitos da monensina sobre a digestibilidade da matéria orgânica, da fibra ou do amido, quer a dieta de novilhos possuísse $10 \%$ ou $20 \%$ de volumosos.

Apesar de vários pesquisadores terem demonstrado efeitos benéficos dos ionóforos sobre a digestibilidade ou degradabilidade dos alimentos, outros não tem apresentado qualquer efeito, existindo aqueles que reportaram efeitos indesejáveis. Pelo fato do acetato ser o metabólito predominante da digestão microbiana da celulose e sendo que os ionóforos diminuem a proporção molar de acetato, foi antecipado que estes compostos poderiam deprimir a digestão da fibra. Em 1978, Lemenager et al. registraram que a monensina diminuiu em $12,1 \%$ a digestibilidade in vitro da MS de um volumoso de gramínea de baixa qualidade quando o inóculo era oriundo de animal não adaptado a este produto, mas apenas uma tendência em diminuição deste parâmetro, da ordem de $3,9 \%$, foi observada quando o inóculo provinha de um animal adaptado. A mesma conclusão pode ser obtida do trabalho de Simpson (1978), o qual observou que a monensina era um potente inibidor da atividade celulolítica in vitro quando o inóculo era obtido de animais não previamente expostos à ela. Poos et al. (1979) confirmaram este efeito adaptativo ao observarem diminuição da digestibilidade da MS (6,3 a 11,3\%) e FDA $(5,3$ a 14,5\%) quando administraram monensina a ovinos durante um período de adaptação de 10 dias, porém ao estenderem este período para 40 dias, estes parâmetros aproximaram-se do grupo controle. Em 1979, Chen \& Wolin explicaram que algumas bactérias celulolíticas eram moderadamente sensíveis à monensina e/ou à lasalocida e que poderia haver, ainda, rápida seleção de microorganismos ruminais resistentes quando da utilização destes compostos, justificando não somente a diminuição da digestão da fibra, como também o efeito adaptativo.

Uma teoria proposta por Chow \& Russell (1992) tenta explicar, ainda, as possíveis diferenças observadas entre a monensina e a lasalocida quanto a digestão da fibra, como foi mencionado anteriormente. Estudos in vitro demostraram que baixas concentrações de monensina eram mais efetivas contra certas espécies de bactérias 
celulolíticas (Fibrobacter succinogenes) do que a lasalocida, e que esta diferença poderia estar relacionada à hidrofobicidade dos ionóforos. Desde que a lasalocida é mais lipofilica do que a monensina, mais lasalocida seria aprisionada na cápsula da célula e menor porção do produto reagiria com a membrana celular. A lasalocida seria mais efetiva contra algumas espécies de bactérias gram-positivas (S. bovis.) que a monensina, já que este grupo não dispõe de uma espessa membrana externa para proteção da interna (Chow \& Russell, 1992).

Uma outra teoria, desta vez de ação indireta, assume que a produção de quantidades adequadas de ácidos graxos voláteis de cadeia ramificada é essencial para a atividade fermentativa das bactérias celulolíticas e conseqüente digestão da fibra (Allison \& Bryant, 1958). A observação de que a monensina diminuía a produção desses compostos (Richardson et al., 1976), com conseqüente diminuição da digestão da fibra, parece ter sido explicada pela descoberta de uma bactéria denominada Peptostreptococcus sp., a qual era grande produtora desses ácidos e também sensível à monensina (Chen \& Russell, 1989).

Além dos já citados, outros experimentos têm demonstrado diminuição da digestão da fibra quando realizados in vitro. Whetstone et al. (1981) mostraram que a monensina não alterou a utilização de glicose ou amido pelas bactérias, mas diminuiu a degradação de celulose em $19,4 \%$ a $31,0 \%$, apesar de não ter alterado o crescimento celular, e Bogaërt et al. (1989), utilizando líquido ruminal de carneiros adaptados à lasalocida e catiomicina durante 30 dias, observaram que a degradação da celulose foi $12 \%$ maior para o grupo controle. Entretanto alguns experimentos in vivo foram capazes de demonstrar apenas uma tendência dos ionóforos em diminuir a digestão da fibra (Lemenager et al., 1978; Fredrickson et al., 1993).

Esses achados encorajaram Bogaërt et al. (1991) a sugerir que a diminuição da degradação da fibra, observada em experimentos in vitro, poderia advir de uma alteração na composição da microflora populacional decorrente das altas doses de ionóforos utilizadas nestes experimentos, fato esse, não observado in vivo, onde estes aditivos apenas causariam uma modificação no metabolismo celular dos 
microorganismos ruminais. Registraram também os pesquisadores, apesar de não ser alterada a digestibilidade aparente da MS ou a distribuição da digestão entre os diferentes compartimentos do trato digestivo, além de nenhum efeito ter sido observado sobre a degradabilidade in situ da MS ou da celulose, a sugestão de que a lasalocida poderia aumentar a degradação ruminal da fibra quando o tempo de retenção é alto e poderia diminuí-la quando o tempo é baixo.

Rodrigues (1996), testando os efeitos da lasalocida em bovinos recebendo dietas com $40 \%$ ou $70 \%$ de volumoso, observou que a lasalocida na dosagem de 200 $\mathrm{mg} / \mathrm{animal} /$ dia interagia com a proporção de volumoso na dieta, de forma que rações com $70 \%$ de volumoso, em relação àquelas com 40\%, propiciaram maior degradabilidade efetiva da fibra (FDN e FDA) na ausência de lasalocida, mas não na sua presença, indicando que este ionóforo tenha aumentado a degradabilidade da fibra em $2,1 \%$ a $5,7 \%$ em dietas predominantemente concentradas e diminuído em $2,3 \%$ a $4,4 \%$ naquelas predominantemente volumosas.

Entretanto, além da interação com o nível de fibra da dieta, espera-se que a dosagem ou concentração do ionóforo também interfira nos resultados, fato esse demonstrado por Faulkner et al. (1985) que, ao alimentarem bovinos adaptados à monensina e recebendo uma dieta rica em fibras, observaram uma resposta quadrática para a digestibilidade da matéria orgânica e FDN, com melhores resultados para dosagens intermediárias de monensina (100 mg/animal/dia) em relação a altos níveis (200 mg/animal/dia) ou controle ( $0 \mathrm{mg} /$ animal/dia), concluindo que a dose de 200 $\mathrm{mg} / \mathrm{animal} / \mathrm{dia}$ é bastante alta para animais submetidos a dietas ricas em fibra.

\subsubsection{Utilização da proteína}

Vários trabalhos tem demonstrado efeitos benéficos dos ionóforos sobre a utilização da proteína pelo animal e várias são as teorias que tentam explicar tal efeito. Com relação aos trabalhos que observaram diminuição da proteólise em conseqüência à inibição do crescimento bacteriano, Poos et al. (1979) observaram diminuição no 
nitrogênio de origem bacteriana e aumento no de origem vegetal que chegava ao abomaso; Faulkner et al. (1985) relataram diminuição da degradação protéica e/ou síntese de proteína bacteriana no rúmen; Rodriguez et al. (1986) observaram diminuição dos niveis extracelulares de amônia contida na fase líquida do conteúdo ruminal sem alteração dos niveis de aminoácidos e Gomez et al. (1991) relataram diminuição no fluxo de nitrogênio microbiano e aumento no fluxo de nitrogênio da proteína não degradada oriunda da dieta com a utilização de ionóforos.

Russell et al. (1988), ao isolarem um novo grupo de bactérias Gram positivas que produzia 20 vezes mais amônia e que era sensivel à monensina, concluiram que os efeitos protetores dos ionóforos sobre as proteinas poderiam ser explicados pela sua atividade contra bactérias que fermentavam peptídios e aminoácidos. Chen \& Russell (1991) vieram a reafirmar esta idéia ao mostrar que a inibição de bactérias Gram negativas e positivas através do TCS $\left(3,3^{\prime}, 4^{\prime}, 5-\right.$ tetraclorosalicilanida), um protonóforo que inibe esses dois grupos de bactérias, não causava maior diminuição nos niveis de amônia que a monensina, a qual é primariamente efetiva contra bactérias Gram positivas. Posteriormente foi demonstrado que esta cepa era a única bactéria ruminal sensivel à monensina e que poderia fermentar lisina, desde que este aminoácido estivesse em altos níveis (Van Kessel \& Russell, 1992).

Experimentos recentes trazem dados ainda mais intrigantes quanto aos efeitos dos ionóforos sobre a utilização das proteínas. Yang \& Russell (1993), ao alimentarem vacas não-lactantes com feno e diferentes níveis de farelo de soja, observaram que a administração de monensina diminuía em $30 \%$ os níveis ruminais de amônia, acompanhada de uma diminuição similar na atividade especifica de produção desta amônia (nmol de amônia/mg de proteina/minuto). Este fato foi concomitante a uma diminuição em 10 vezes no número das bactérias que poderiam utilizar peptídios e aminoácidos, ao invés de carboidratos, como fonte de energia. Apesar da monensina não ter aumentado os níveis de proteína solúvel, peptídios e aminoácidos no líquido ruminal, ela aumentou a concentração em proteína bacteriana. Concluiu-se que peptídeos e 
aminoácidos, protegidos da deaminação, foram convertidos em proteína microbiana por cepas resistentes ao ionóforo, o que poderia prover fluxo adicional de nitrogênio de origem bacteriana para o trato digestivo posterior, ao invés de nitrogênio de origem dietética. Tais resultados foram confirmados por Lana \& Russell (1997).

Por último, não se pode deixar de citar o trabalho de Funk et al. (1986) que, ao observarem que a lasalocida não alterou a digestibilidade do nitrogênio, bem como o balanço nitrogenado ou a concentração ruminal de amônia, mas tendeu em diminuir os níveis séricos de uréia em ovinos recebendo dieta composta de $65 \%$ de concentrados, concluíram que o efeito protéico-protetor dos ionóforos seria explicado, como proposto primeiramente por Beede et al. (1986b), pelo aumento do suprimento de propionato, o qual, por ser gliconeogênico, diminuiria a utilização da proteína absorvida para gliconeogênese ou oxidação nos tecidos.

Tão importantes quanto a causa metabólica responsável pela melhora na utilização da proteína ocasionada pelos ionóforos são os diversos fatores que alteram esta resposta, mas nem por isso os resultados são menos conflitantes. Araujo-Febres \& Fernández (1991), ao estudarem os efeitos da monensina em novilhos submetidos à dietas com $15 \%$ e $26 \%$ de fibra bruta durante 42 dias, observaram aumento da digestibilidade da proteina bruta em $2,7 \%$ para a dieta alta em fibra e significativamente maior, na ordem de $32,7 \%$, para a dieta baixa em fibra. Estes dados concordam com os obtidos por McCann et al. (1990) que, ao alimentarem ovinos com dietas contendo 25\%, $50 \%$ e $75 \%$ de volumosos, observaram que a monensina melhorou a digestibilidade do nitrogênio em $11,8 \%$ somente em animais recebendo dietas com $25 \%$ de volumoso e quando este era tratado com $\mathrm{NaOH}$. Zinn et al. (1994) observaram que a monensina aumentava a quantidade de nitrogênio microbiano que chegava ao abomaso, e diminuía o nitrogênio de origem dietética, independentemente se os animais recebessem $10 \%$ ou $20 \%$ de volumosos na dieta. Entretanto, nenhum efeito foi observado sobre a digestão total do $\mathrm{N}$.

Alguns trabalhos tem demonstrado resultados diferentes com relação à dosagem utilizada. Bartley et al. (1979), realizando estudos in vitro com monensina e 
lasalocida, observaram que ambos aditivos diminuíram a síntese de proteína e que este efeito foi maior para a monensina em altos níveis, quando comparada à lasalocida, mas não em concentrações menores.

Dada a variabilidade das respostas obtidas com a utilização de ionóforos, vários trabalhos não apresentaram resultados estatisticamente significativos. Sip \& Pritchard (1991), ao alimentarem novilhos com dietas constituídas por $80 \%$ de concentrados e diferentes níveis protéicos $(90 \%, 100 \%, 110 \%$ e $120 \%$ dos requerimentos), não observaram interações entre o nível de monensina e o de $\mathrm{PB}$ da dieta sobre o desempenho animal, atribuindo o aumento na resposta obtida com a monensina (7,6\% no ganho de peso diário) à melhora no metabolismo energético e não ao seu efeito protéico-protetor, o que foi, ainda, substanciado pelo fato da monensina não ter provocado nenhum efeito nas concentrações plasmáticas de uréia.

Outros trabalhos não apresentaram efeitos dos ionóforos sobre a digestibilidade da $\mathrm{PB}$ quando o experimento foi realizado em bezerros e ovelhas recebendo dietas peletizadas contendo $20 \%, 40 \%$ e $60 \%$ de volumosos e adicionadas de monensina (Pomar et al., 1989); sobre a digestibilidade do nitrogênio e retenção deste elemento nos tecidos quando novilhos receberam dietas com $12 \%, 27 \%$ e $40 \%$ de FDN e adicionadas de monensina (Thornton \& Owens, 1981); sobre as concentrações ruminais de nitrogênio amoniacal de vacas leiteiras recebendo dietas com $30 \%$ ou $50 \%$ de concentrados (Ramanzin et al., 1997); sobre as concentrações de nitrogênio amoniacal no meio de cultura contendo dietas com $0 \%, 50 \%$ ou $90 \%$ de concentrados (GarciaLopez et al., 1996) ou sobre a degradabilidade efetiva da MS ou PB do farelo de soja quando este alimento foi incubado no rúmen de bovinos recebendo dietas com $40 \%$ ou $70 \%$ de volumoso mais lasalocida (Rodrigues, 1996). Entretanto este último pesquisador, ao observar que este produto aumentou a fração rapidamente degradável (parâmetro $a$ da equação de Ørskov \& McDonald, 1979) da PB do farelo de soja em $12,3 \%$, suspeitou da possibilidade dos resultados gerados neste experimento estarem tendenciados em conseqüência da possível heterogeneidade de concentração de lasalocida no líquido ruminal ao longo do dia, fato que poderia resultar em maior ou 
menor efeito sobre os microorganismos ruminais, dependendo do tempo em que cada amostra foi incubada e da duração dos efeitos da aplicação de ionóforos. Mas de qualquer forma esta possibilidade implicaria em atividade proteolítica inibida, durante $\mathrm{o}$ prazo em que há altas concentrações de lasalocida no líquido ruminal, mas aumentada quando esta concentração baixasse, podendo até anularem-se os efeitos já obtidos.

\subsubsection{Volume líquido ruminal e taxa de passagem de líquidos}

Pesquisas realizadas por Lemenager et al. (1978), em novilhos recebendo dieta a base de $70 \%$ de volumoso de baixa qualidade, demonstraram que a monensina diminuiu a taxa de passagem sólida e o volume líquido ruminal em 43,6\% e $26,2 \%$, respectivamente, e apresentou tendência em diminuir a taxa de passagem de líquidos em $30,8 \%$, porém nenhum efeito foi observado sobre o enchimento ruminal de MS. Ao utilizarem dietas predominantemente concentradas, a monensina diminuiu significativamente a taxa de passagem de líquidos em $9,6 \%$ a $22,0 \%$. Da mesma forma, ao alimentarem ovinos com dieta contendo $66,7 \%$ de volumosos adicionada de lasalocida ou monensina, Ricke et al. (1984) também observaram que esses aditivos tenderam em diminuir a taxa de passagem de sólidos em 13,0\% e 15,2\% e de líquidos em $5,9 \%$ e $9,8 \%$, respectivamente, sem, contudo, causarem alterações sobre volume líquido ruminal.

Entretanto, Rogers \& Davis (1982) mostraram que a monensina não alterou o volume líquido ruminal, a taxa de passagem de líquidos pelo rúmen, o fluxo total de líquidos e o fluxo total de líquidos por quilo de MS consumida em novilhos alimentados com uma dieta composta de $50 \%$ de volumoso. Estes pesquisadores afirmaram que, em estudos onde a adição de monensina reduzia o consumo de alimentos, como observado no experimento de Lemenager et al. (1978), a taxa de passagem de líquidos seria diminuída em virtude de uma marcante redução na ingestão de água e no fluxo salivar decorrente da menor ingestão. Essa diminuição na ingestão de alimentos permitiria aumento no tempo de retenção da matéria seca no rúmen, a qual 
seria em grande parte responsável pelos efeitos dos ionóforos. Essa hipótese é substanciada por outros trabalhos onde os ionóforos não alteraram os parâmetros de dinâmica ruminal (Rodriguez et al., 1986; Yang \& Russell, 1993; Galloway et al., 1993; Fredrickson et al., 1993; Bogaert et al., 1991; Poos et al., 1979; Knowlton et al., 1996b; Rodrigues, 1996).

\subsubsection{Outros}

Entre a sétima categoria de ação dos ionóforos inclui-se a possibilidade de menor incidência de edema e enfisema pulmonar em bovinos (Boren et al., 1982, citado por Schelling, 1984), efeito anticetogênico dos ionóforos em vacas leiteiras (Sauer et al., 1989; Duffield et al., 1998), sem alterar a produção ou composição do leite (Sauer et al., 1989), diminuição da incidência de timpanismo em ruminantes (Branine \& Galyean, 1990), diminuição no número e capacidade de sobrevivência de pupas de mosca do chifre nas fezes de bovinos (Herald et al., 1982) e alteração do status mineral (Reffett-Stabel et al., 1989; Stephenson et al., 1997) e lipídico (Marounek et al., 1990) dos animais, diminuindo inclusive a lipólise (Van Nevel \& Demeyer, 1995), a biohidrogenação ruminal (Fellner et al., 1997) ou a proporção de ácidos graxos saturados no leite (Sauer et al., 1997). 


\section{MATERIAL E MÉTODOS}

\subsection{Experimento 1 - Bovinos}

\subsubsection{Animais}

Foram utilizadas nove fềmeas bovinas mestiças holandês $\mathrm{x}$ zebu, com grau de sangue variável, portadoras de cânulas ruminais com $10 \mathrm{~cm}$ de diâmetro e 7,5 cm de espessura. Os animais apresentavam-se não lactantes e não gestantes, possuindo aproximadamente $470 \mathrm{~kg}$ de peso vivo ao início do experimento. Estes eram dóceis o suficiente para permitir a coleta de amostras com mínima interferência sobre o consumo de alimentos.

\subsubsection{Instalações}

Foram utilizadas as instalações do Estábulo Experimental da Prefeitura do Campus Administrativo de Pirassununga - USP. Estas consistiam basicamente de baias individuais com cochos de cimento, que permitiam avaliar o consumo de alimentos, e bebedouros automáticos comuns a cada dois animais. O piso era forrado com tapete de borracha e havia, ainda, a presença de ventiladores suspensos ao teto, que eram ligados nas horas mais quentes do dia.

A pesagem dos animais foi realizada em balança da marca Filizola, com capacidade de $1.500 \mathrm{~kg}$ e sensibilidade de $500 \mathrm{~g}$. 


\subsubsection{Tratamentos e delineamento experimental}

Foi utilizado o delineamento inteiramente casualizado (Pimentel Gomes, 1985) dividido em 3 sub-períodos com um arranjo fatorial de tratamentos do tipo $3 \times 3$ (Tabela 1) correspondendo ao fator monensina sódica na dosagem de zero, 150 e 300 mg por animal e por dia e três proporções de concentrados na dieta: $25 \%, 50 \%$ e $75 \%$. Foram realizadas, ainda, medidas repetidas no tempo, as quais corresponderam às coletas de conteúdo ruminal ao longo do dia.

Tabela 01. Delineamento inteiramente casualizado, com 9 animais e 3 sub-períodos.

\begin{tabular}{cccccccccc}
\hline Sub- & \multicolumn{10}{c}{ Animais } \\
\cline { 2 - 10 } períodos & 1 & 2 & 3 & 4 & 5 & 6 & 7 & 8 & 9 \\
\hline I & A & B & C & D & E & F & G & H & I \\
II & E & F & D & H & I & G & B & C & A \\
II & I & G & H & C & A & B & E & F & D \\
\hline
\end{tabular}

Como fonte de monensina sódica foi utilizado o produto comercial Rumensin $\circledast$ (ELANCO), com $10 \%$ de monensina sódica, que foi pesado em balança analítica e acondicionado em envelopes confeccionados em papel. $\mathrm{O}$ produto era administrado aos animais durante o momento das refeições, misturado à mistura de concentrados por meio de agitação manual.

As dietas foram formuladas para serem isonitrogenadas (Tabela 2), sendo o concentrado constituído de grãos de milho moído, farelo de soja, sal branco, mistura mineral e calcário calcítico. O volumoso utilizado foi o feno de Tifton $85 \mathrm{com}$ aproximadamente $8,5 \%$ de proteína bruta. A ração foi fornecida em duas refeições, às 7:00 e 16:00 h, e o volumoso oferecido após a ingestão de toda a mistura concentrada, sendo compostas as proporções volumoso:concentrados com base na matéria seca. A quantidade de ração fornecida foi calculada em função do consumo durante o período de adaptação, de forma a não existirem sobras. Amostras da dieta (feno e misturas concentradas) foram realizadas diariamente durante a terceira semana de cada subperíodo experimental, de forma a comporem uma amostra composta. 
Tabela 02. Proporções de ingredientes utilizados e composição bromatológica das rações utilizadas no experimento com bovinos, com base na matéria seca.

\begin{tabular}{|c|c|c|c|}
\hline & \multicolumn{3}{|c|}{ Proporção de Concentrados } \\
\hline Ingredientes $(\%)$ & $25 \%$ & $50 \%$ & $75 \%$ \\
\hline Feno de Tifton 85 & 75,0 & 50,0 & 25,0 \\
\hline Grãos de milho moídos & 12,1 & 38,4 & 64,5 \\
\hline Farelo de soja & 11,9 & 10,6 & 9,30 \\
\hline Sal branco & 0,50 & 0,50 & 0,50 \\
\hline Mistura mineral ${ }^{1}$ & 0,50 & 0,50 & 0,50 \\
\hline Calcário calcítico & $\overline{100,0}$ & - & $\begin{array}{c}0,20 \\
100,0\end{array}$ \\
\hline \multicolumn{4}{|l|}{ Composição } \\
\hline$\overline{M S}(\%)$ & 88,80 & 88,00 & 87,70 \\
\hline PB (\%) & 14,05 & 14,18 & 14,66 \\
\hline Proteína não degradável (\%) & 31,81 & 35,84 & 39,89 \\
\hline Proteína degradável (\%) & 68,19 & 64,16 & 60,11 \\
\hline FDA $(\%)$ & 37,08 & 27,83 & 17,30 \\
\hline $\operatorname{FDN}(\%)$ & 69,81 & 51,57 & 33,88 \\
\hline FDN efetivo (\%) & 66,95 & 45,90 & 24,97 \\
\hline $\mathrm{EE}(\%)$ & 0,90 & 1,36 & 1,86 \\
\hline $\mathrm{MM}(\%)$ & 6,14 & 4,82 & 3,38 \\
\hline Carboidratos não estrut. (\%) & 9,10 & 28,07 & 46,22 \\
\hline NDT estimado (\%) & 58,14 & 66,86 & 75,42 \\
\hline $\mathrm{Ca}(\%)$ & 0,55 & 0,48 & 0,47 \\
\hline $\mathrm{P}(\%)$ & 0,49 & 0,48 & 0,48 \\
\hline
\end{tabular}

Composição por $\mathrm{kg}$ de mistura mineral: $180 \mathrm{~g} \mathrm{Ca}, 90 \mathrm{~g} \mathrm{P}, 20 \mathrm{~g} \mathrm{Mg}, 20 \mathrm{~g} \mathrm{~S}, 100 \mathrm{~g} \mathrm{Na}, 155 \mathrm{~g} \mathrm{Cl}, 3.000 \mathrm{mg} \mathrm{Zn}$, $1.000 \mathrm{mg} \mathrm{Cu}, 1.250 \mathrm{mg} \mathrm{Mn}, 2.000 \mathrm{mg} \mathrm{Fe}, 100 \mathrm{mg} \mathrm{Co}, 90 \mathrm{mg} \mathrm{I}, 20 \mathrm{mg} \mathrm{Se}, 900 \mathrm{mg}$ F (máximo).

\subsubsection{Período experimental}

O experimento foi iniciado em 07 de janeiro de 1998 e teve duração total de 63 dias divididos em 3 sub-períodos de 21 dias cada, dos quais os primeiros 10 dias foram destinados à adaptação dos animais às dietas. Entre o $11^{\circ}$ e o $21^{\circ}$ dia foi feita avaliação da digestibilidade in vivo, entre o $17^{\circ}$ e $020^{\circ}$ dia a avaliação da degradabilidade in situ, $\mathrm{o} 21^{\circ}$ foi usado para a colheita de líquido ruminal e o $20^{\circ}$ e $22^{\circ}$ 
(primeiro dia do período seguinte) para a coleta de inóculo utilizado no ensaio de digestibilidade in vitro.

Pesagens dos animais foram realizadas no início e final de cada subperíodo e antes da primeira refeição do dia.

As variáveis analisadas foram:

- consumo de matéria seca;

- $\mathrm{pH}$ do conteúdo ruminal;

- dosagem de ácidos graxos voláteis (AGVs) acético, propiônico e butírico no conteúdo ruminal;

- dosagem dos níveis de nitrogênio amoniacal no conteúdo ruminal;

- taxa de passagem de líquidos e volume líquido ruminal;

- digestibilidade ruminal in situ da matéria seca (MS) e proteína bruta (PB) do farelo de soja, MS, fibra em detergente neutro (FDN) e fibra em detergente ácido (FDA) do feno de Tifton 85 e da MS de grãos de milho moídos;

- digestibilidade in vivo da MS e suas frações através do óxido crômico;

- digestibilidade in vitro do farelo de soja com inóculo obtido 3 ou 15 horas após administração da monensina.

\subsubsection{Descrição das coletas de conteúdo ruminal}

As amostras de conteúdo ruminal foram coletadas em três pontos diferentes correspondentes ao antro e saco ventrais anterior e posterior, através de uma bomba de vácuo. Foram retirados pelo menos $500 \mathrm{ml}$ de conteúdo ruminal, que eram devolvidos ao pró-ventrículo, após colheita das devidas alíquotas. Exceto para as amostragens referentes à mensuração do volume e taxa de passagem de líquidos, todas as demais (AGVs, amônia e pH) foram realizadas às $0 \mathrm{~h}, 2 \mathrm{~h}, 4 \mathrm{~h}, 6 \mathrm{~h}, 8 \mathrm{~h}, 10 \mathrm{~h}$ e 12 horas após o arraçoamento matinal, efetuado às $8: 00 \mathrm{~h}$. A amostra referente à $0 \mathrm{~h}$ foi realizada imediatamente antes que os animais recebessem a primeira refeição. A segunda refeição foi oferecida somente às 20:00 h, quando encerradas as amostragens. 


\subsubsection{Métodos analíticos}

\subsubsection{Metodologia de determinação do $\mathrm{pH}$ do conteúdo ruminal}

Imediatamente após a coleta de líquido ruminal, $100 \mathrm{ml}$ de fluído ruminal foram utilizados para a determinação do $\mathrm{pH}$ em potenciômetro digital de mesa (marca Procyon, modelo 310), calibrados com soluções tampão de pH 4,0 e 7,0.

\subsubsection{Metodologia de determinação dos AGVs}

Uma alíquota de aproximadamente $100 \mathrm{ml}$ de líquido ruminal foi centrifugada a $3.500 \mathrm{rpm}(2.000 \mathrm{G})$ por 15 minutos; $1 \mathrm{ml}$ do sobrenadante foi colocado em um tubo de ensaio arrolhado e adicionou-se $0,2 \mathrm{ml}$ de ácido fórmico P.A., armazenando-se em congelador $\mathrm{a}-20^{\circ} \mathrm{C}$ até o momento da análise.

A determinação dos AGVs contidos no líquido ruminal foi realizada através de cromatografia gasosa, segundo método preconizado por Erwin et al. (1961), no Laboratório de Nutrição Animal do Departamento de Nutrição e Produção Animal da Faculdade de Medicina Veterinária e Zootecnia da Universidade de São Paulo (VNP/FMVZ/USP). Para tal, foi utilizado um cromatógrafo a gás (marca Finnigan, modelo 9001) equipado com coluna de vidro de 2 metros de comprimento e $2 \mathrm{~mm}$ de diâmetro empacotada com 80/120 Carbopack $^{\mathrm{TM}}$ B-DA/4\% Carbowax ${ }^{\circledR} 20 \mathrm{M}$. Os gases utilizados foram o nitrogênio, como gás de arraste na vazão de 25 mililitros por minuto, oxigênio, como gás comburente na vazão de $175 \mathrm{ml} / \mathrm{min}$, e hidrogênio, como gás combustível na vazão de $18 \mathrm{ml} / \mathrm{min}$. As temperaturas utilizadas para operação do vaporizador e detector de ionização de chamas foram 260 e 280 graus Celsius, respectivamente. A coluna de separação iniciou a corrida com $155^{\circ} \mathrm{C}$ durante 2 minutos, foi aumentada até $210^{\circ} \mathrm{C}$ a uma taxa de $10^{\circ} \mathrm{C}$ por minuto, perfazendo um tempo total de corrida de 11 minutos. 
Foram preparadas soluções $0,1 \mathrm{~N}$ dos ácidos acético, propiônico e butírico, as quais tiveram suas respectivas normalidades determinadas com maior acuidade através da titulação com uma solução padronizada de $\mathrm{KOH}$, de forma a produzir uma solução padrão de AGVs de concentração conhecida.

As determinações foram realizadas injetando-se 1,0 microlitro de amostra ao cromatógrafo. Este era integrado a um computador que processava os cálculos de quantificação através do programa computacional Borwin (versão 1.21) para cromatografia, utilizando-se a solução padrão como base para o cálculo das concentrações de AGVs da amostra. O número de repetições por amostra foi aquele necessário para que a diferença entre leituras fosse inferior a $5 \%$. A solução padrão foi injetada a cada 10 injeções sucessivas de amostras, tentando-se evitar, desta maneira, possíveis distorções das leituras em função da contaminação da coluna.

Os cálculos das concentrações de AGVs foram realizados em microcomputador, comparando-se as amostras a uma solução padrão contendo a concentração de $57,62 \mathrm{mM}(66,7 \%$ com base na proporção molar $)$ de ácido acético $\left(\mathrm{C}_{2}\right)$, 16,45 mM (19,0\%) de ácido propiônico $\left(\mathrm{C}_{3}\right), 12,43 \mathrm{mM}(14,3 \%)$ de ácido butírico $\left(\mathrm{C}_{4}\right)$. Assim como a amostra de líquido ruminal, a solução padrão também foi adicionada de $0,2 \mathrm{ml}$ de ácido fórmico P.A. para cada $1 \mathrm{ml}$ de solução de AGVs de concentração conhecida.

\subsubsection{Metodologia de determinação da concentração de nitrogênio amoniacal}

Alíquotas de $2 \mathrm{ml}$ de líquido ruminal foram colocadas em tubos de ensaio contendo $1 \mathrm{ml}$ de solução de ácido sulfúrico $1 \mathrm{~N}$ e armazenadas sob refrigeração até a realização das análises.

A determinação do nitrogênio amoniacal $\left(\mathrm{N}^{\left.-\mathrm{NH}_{3}\right)}\right.$ foi realizada por colorimetria, segundo método proposto por Kulasek (1972) e adaptado por Foldager (1977). A desproteinização foi feita adicionando-se $1 \mathrm{ml}$ de tungstato de sódio $10 \%$ ao 
tubo contendo a amostra fixada e posteriormente centrifugando-se a $3.000 \mathrm{rpm}$ ( 2.000 $\mathrm{G})$ por 15 minutos. Foram pipetados 25 microlitros do sobrenadante que, colocados em tubos de ensaio, foram acrescidos de $5 \mathrm{ml}$ de reagente fenol (50 $\mathrm{mg}$ de nitroprussiato de sódio e $10 \mathrm{~g}$ de cristais de fenol diluídos em 1 litro de água destilada) e $5 \mathrm{ml}$ de reagente hipoclorito ( $10 \mathrm{~g}$ de hidróxido de sódio, 21,3 g de fosfato de sódio dibásico anidro e 25 $\mathrm{ml}$ de solução de hipoclorito de sódio $5 \%$ diluídos em 1 litro de água destilada). Os tubos foram arrolhados, agitados e mantidos em banho-maria a $37^{\circ} \mathrm{C}$ por 15 minutos.

As leituras em absorbância foram realizadas em espectofotômetro (marca Beijing Rayleigh AIC modelo VIS-7220) regulado em $630 \mathrm{~nm}$. Os valores de absorbância foram utilizados para calcular as concentrações de amônia em mg de N$\mathrm{NH}_{3} / 100 \mathrm{ml}$, através de equação de regressão linear obtida a partir da calibração do aparelho com soluções-padrão de diferentes concentrações. Admitiu-se um $\mathrm{R}^{2}$ mínimo de 0,99 para esta curva. O aparelho foi zerado através de branco contendo soluções de tungstato de sódio $10 \%$, solução de $\mathrm{H}_{2} \mathrm{SO}_{4} 1 \mathrm{~N}$ e água destilada diluídos em reagente fenol e hipoclorito nas devidas proporções.

\subsubsection{Metodologia de determinação da digestibilidade in situ}

As digestibilidades ruminais da matéria seca e proteína bruta do farelo de soja, matéria seca, fibra em detergente neutro e fibra em detergente ácido do feno de Tifton 85 e da matéria seca dos grãos de milho moídos foram medidas através da técnica de sacos de náilon in situ conforme descrito por Mehres \& Ørskov (1977). Para tal, utilizaram-se sacos (ou sacolas) confeccionados em tecido de náilon, com porosidade de 50 micras, medindo $10,0 \times 19,0 \mathrm{~cm}$ que abrigaram as amostras de alimentos e duas esferas de vidro, que possuíam a função de mantê-los submersos no conteúdo ruminal.

O farelo de soja, o feno e os grãos de milho colocados nos sacos foram os mesmos utilizados para compor as dietas, sendo estes ingredientes coletados em vários pontos do local de armazenamento de forma a evitar problemas de amostragem. Os ingredientes foram secados em estufa de ar forçado a $65^{\circ} \mathrm{C}$ por 72 horas, sendo o feno 
moído em moinho do tipo Wiley-mill com peneira de $6 \mathrm{~mm}$. Os sacos previamente identificados foram pesados em balança analítica de precisão e, então, receberam aproximadamente 5 gramas da amostra de farelo de soja, do feno de Tifton 85 picado ou grãos de milho moídos separadamente. Após serem amarrados, as sacolas foram armazenadas em câmara fria $\left(-5^{\circ} \mathrm{C}\right)$ até o momento do uso.

Durante a incubação, os sacos foram presos à cânula ruminal através de um fío de náilon com comprimento mínimo de $50 \mathrm{~cm}$, permitindo sua livre movimentação no interior do rúmen.

Sendo o tempo de incubação função do material testado (Ørskov, 1982), os sacos foram incubados durante $0 \mathrm{~h}, 1,5 \mathrm{~h}, 3 \mathrm{~h}, 6 \mathrm{~h}, 12 \mathrm{~h}, 24 \mathrm{~h}$ e 48 horas para as amostras de farelo de soja e grãos de milho e $0 \mathrm{~h}, 6 \mathrm{~h}, 12 \mathrm{~h}, 24 \mathrm{~h}, 48 \mathrm{~h}, 72 \mathrm{~h}$ e 96 horas para as de feno. Imediatamente após a retirada dos sacos, nos tempos pré-determinados, eles foram lavados à mão e em água corrente até que o líquido de lavagem fluísse incolor, sendo então colocados em estufa a $65^{\circ} \mathrm{C}$ por 72 horas para posteriormente serem pesados e submetidos às análises bromatológicas. De forma a permitir a obtenção da concentração da fração solúvel, a degradabilidade em tempo zero foi tomada mergulhando-se os sacos em um recipiente contendo água à temperatura de $39^{\circ} \mathrm{C}$ durante 10 minutos (Cummins et al., 1983). As análises bromatológicas de PB foram avaliadas segundo A.O.A.C. (1980) e de FDN e FDA segundo Goering \& Van Soest (1970), sendo o farelo de soja, obtido após incubação, previamente processado em moinho Wiley mill com peneira de $1 \mathrm{~mm}$.

A degradabilidade da matéria seca foi tomada através da diferença de pesagens das sacolas antes e após a incubação, com base na amostra seca a $65^{\circ} \mathrm{C}$ por 72 horas. A fórmula utilizada foi a seguinte:

$$
\operatorname{DgMS} \%=100 \times[1-(\mathrm{PSPI}-\mathrm{PSV}) /(\mathrm{PSAI}-\mathrm{PSV})]
$$


Onde: $\mathrm{DgMS} \%$ = Degradabilidade da MS em porcentagem;

PSPI = Peso do Saco Pós-incubação;

PSAI = Peso do Saco Antes da Incubação;

PSV $=$ Peso do Saco Vazio.

A degradabilidade da PB do farelo de soja e da FDN e FDA do feno foram calculadas através da mesma fórmula, sendo que a diferença entre peso do saco antes da incubação, ou pós-incubação, e o peso do saco vazio foram multiplicados pelas respectivas porcentagens de $\mathrm{PB}, \mathrm{FDN}$ e FDA, dividindo-se este resultado por cem.

Os dados de degradabilidade foram ajustados pelo modelo de Ørskov \& McDonald (1979), os quais propuseram a seguinte equação exponencial para expressar a degradabilidade dos alimentos: $p=a+b\left(l-e^{-c t}\right)$, onde $p$ é a quantidade degradada ao tempo $(t), a$ é a interseção da curva no tempo zero e pode ser interpretada como a fração rapidamente solúvel, $b$ é a fração potencialmente degradável e expressa a fração que será degradada no tempo e $c$ a taxa de degradação na qual a fração descrita por $b$ será degradada por hora. A letra $e$ é o log natural de $-c t$. Os parâmetros do modelo de regressão não linear pelo método de quadrados mínimos foram obtidos através do procedimento não linear (PROC NLIN) do programa computacional Statistical Analysis System (SAS Institute Inc., 1985).

As constantes $a, b$ e $c$ da equação exponencial foram utilizadas para calcular a degradabilidade potencial $(\mathrm{Dp}=a+b)$, representada pela quantidade de alimento que pode se solubilizar ou degradar dentro do rúmen se o tempo não for fator limitante, e a degradabilidade efetiva (De), a qual representa a quantidade de alimento realmente degradado, definida pelo tempo na qual o mesmo está presente no rúmen (Ørskov et al., 1980). A degradabilidade efetiva (De) é calculada através da seguinte fórmula: $\mathrm{De}=a+(b \times c) /(c+k)$, onde $k$ representa a taxa de saída do alimento do rúmen por hora, podendo variar de 0,01 a 0,1 (Ørskov et al., 1980).

No presente estudo, utilizou-se taxas de passagem da matéria seca de $0,02,0,05$ e 0,08 por hora. Recomenda-se o valor de $0,02 / \mathrm{h}$ para animais recebendo 
ração completamente moída e/ou em baixo nível alimentar (uma vez a mantença), $0,05 / \mathrm{h}$ para vacas leiteiras de baixa produção (menos que $15 \mathrm{~kg}$ de leite/dia) ou gado de corte recebendo alto nível de dietas mistas (menos que 2 vezes a mantença) e 0,08/h para vacas leiteiras de alta produção (mais que $15 \mathrm{~kg}$ de leite/dia) recebendo dietas mistas (mais que 2 vezes a mantença) (A.F.R.C., 1992).

\subsubsection{Metodologia de determinação da digestibilidade in vivo}

A digestibilidade in vivo da MS da dieta e suas frações (PB, EE, ENN, FB, FDN e FDA) foram avaliadas através do marcador óxido crômico (Bateman, 1970). Os animais receberam o óxido crômico via cânula ruminal na dosagem de $15 \mathrm{~g}$ do marcador por animal e por dia, sendo as administrações realizadas duas vezes ao dia, no momento das refeições, e através de envelopes confeccionados em papel absorvente. $\mathrm{O}$ ensaio foi constituído de duas fases compreendidas entre os dias 11 e 21 de cada subperíodo, sendo uma fase de administração do marcador e outra de administração do marcador e coleta de fezes, com duração de 5 dias cada uma, assegurando-se desta forma uma excreção homogênea do óxido crômico. Para comporem uma amostra final, alimentos e fezes foram amostrados duas vezes ao dia, próximos às refeições, sendo a de fezes realizada diretamente do reto.

A concentração do óxido crômico foi determinada por colorimetria através de sua reação com a s-difenilcarbazida, segundo Graner (1972).

\subsubsection{Metodologia de determinação da digestibilidade in vitro}

Foi realizada a avaliação da digestibilidade in vitro do farelo de soja pela técnica de uma etapa, como proposto por Baumgardt et al. (1962) e descrito por Silva (1981), para avaliar o efeito do tempo entre alimentação e coleta da amostra de inóculo, e consequentemente a provável diferença de concentração da monensina no líquido ruminal ao longo do dia, sobre o desaparecimento da proteína. Para realizar tal ensaio 
foram coletadas amostras de conteúdo ruminal às $10: 00 \mathrm{~h}$ da manhã do $20^{\circ}$ dia de adaptação, momento em que a concentração de monensina deveria estar alta, já que sua administração no rúmen era realizada às 7:00 $\mathrm{h}$ do mesmo dia, e às $10: 00 \mathrm{~h}$ do $22^{\circ}$ dia, sendo a última administração de monensina realizada às 20:00 horas do dia anterior (21 dia), perfazendo 15 horas entre a última administração e esta coleta de conteúdo ruminal. Acredita-se que este tempo tenha sido suficiente para causar decréscimo substancial das concentrações ruminais de monensina.

O farelo de soja foi incubado durante um período de 12 horas.

\subsubsection{Metodologia de determinação do volume e taxa de passagem de líquidos no rúmen}

A determinação do volume líquido e da taxa de passagem de líquidos pelo rúmen foi realizada através do marcador Polietilenoglicol de peso molecular 4.000 (PEG 4.000).

Ás 7:00 $\mathrm{h}$ do $21^{\circ}$ dia de cada sub-período, após a retirada do último saco, foram introduzidos, através da fistula ruminal, 300g de PEG (Carbowax 4.000, marca Synth) previamente diluídos em aproximadamente $500 \mathrm{ml}$ de água, misturando-se em seguida este marcador com o conteúdo ruminal manualmente. Amostras de líquido ruminal para determinações das concentrações de PEG foram tomadas às $0 \mathrm{~h}, 1 \mathrm{~h}, 3 \mathrm{~h}, 6 \mathrm{~h}$, $9 \mathrm{~h}, 12 \mathrm{~h}$ e 24 horas. A amostra referente ao tempo zero foi coletada imediatamente antes da introdução do PEG, sendo a água e a refeição da manhã fornecidas imediatamente após a coleta da $1 \mathrm{~h}$, ou seja, às 8:00 h, já que os animais foram privados de beber água e se alimentar desde às 0:00 $\mathrm{h}$ (meia-noite) do mesmo dia.

O líquido ruminal foi centrifugado por 10 minutos a $3.500 \mathrm{rpm}(2.000 \mathrm{G})$ no local da coleta e o sobrenadante armazenado sob refrigeração até a realização das análises. A determinação da concentração de PEG foi realizada segundo o método preconizado por Hyden (1956), onde $2 \mathrm{ml}$ de amostra previamente centrifugada foram adicionados de $10 \mathrm{ml}$ de água destilada, $1 \mathrm{ml}$ de cloreto de bário $10 \%, 2 \mathrm{ml}$ de hidróxido 
de bário $0,3 \mathrm{~N}$ e $2 \mathrm{ml}$ de sulfato de zinco $5 \%$, misturados por 5 minutos e centrifugados a $3.500 \mathrm{rpm}$ por 10 minutos para desproteinização. Procedeu-se a turvação do PEG, através da adição de ácido tricloroacético (TCA) 30\% ao sobrenadante diluído em diferentes proporções com água destilada, de acordo com a hora de coleta. Após 5 minutos de espera, procedeu-se as leituras de absorbância em espectofotômetro ajustado para um comprimento de onda igual a $500 \mathrm{~nm}$. Os valores de absorbância, corrigidos para as diluições, foram utilizados para calcular as concentrações de PEG em $\mathrm{mg} / \mathrm{ml}$, através de equação de regressão linear obtida a partir da calibração do aparelho com soluções-padrão de diferentes concentrações. Admitiu-se um $\mathrm{R}^{2}$ mínimo de 0,99 para a curva controle. $\mathrm{O}$ aparelho foi zerado com o uso de água destilada.

A taxa de passagem de líquidos ou taxa eferente de fluxo, em porcentagem por hora, foi calculada através da regressão linear do logarítmo natural da concentração do PEG 4.000 em função do tempo. O volume líquido ruminal, em litros, foi estimado através da extrapolação da concentração inicial (zero hora) e a dosagem do marcador (300g/animal). Estes dados foram ainda utilizados para calcular o fluxo líquido (L/h), o fluxo líquido por $\mathrm{kg}$ de MS consumida por hora (L/kg MS/h) e o volume líquido ruminal em porcentagem do peso vivo (L/100 kg de PV).

\subsubsection{Análise estatística}

Os resultados foram analisados através do programa computacional Statistical Analysis System (SAS Institute Inc., 1985), sendo anteriormente verificada a normalidade dos resíduos pelo Teste de Shapiro-Wilk (PROC UNIVARIATE) e as variâncias comparadas pelo Teste de Hartley (Ott, 1983). Os dados (variável dependente) que não atenderam a estas premissas foram submetidos à transformação logarítmica $(\log X+1)$ ou pela raiz quadrada $[R Q(X+1 / 2)]$. Os dados originais ou transformados, quando este último procedimento foi necessário, foram submetidos à análise de variância que separou como causas de variação efeito de proporção de concentrados, efeito de dose de monensina e efeito de sub-período experimental. Os 
efeitos dos fatores principais (proporção concentrado:volumoso e dose de monensina) foram separados, através do uso de polinômios ortogonais, em efeito linear e desvio da linearidade, enquanto que a interação entre esses fatores foi separada em efeito linear para ambos o fatores, efeito linear para a proporção de concentrados e desvio para a dose de monensina, desvio para a proporção de concentrados e efeito linear para a dose de monensina, e efeito de desvio para ambos o fatores. Tal análise foi realizada utilizado-se procedimento General Linear Model (PROC GLM do SAS).

As análises referentes aos valores de $\mathrm{pH}$, AGVs e concentrações de nitrogênio amoniacal no conteúdo ruminal e, ainda, digestibilidade in vitro do farelo de soja foram analisados conforme descrito anteriormente, porém foram adicionados do fator medidas repetidas no tempo, referentes aos diversos momentos de colheita entre as refeições (Tabela 3). As probabilidades das interações com o tempo foram determinadas pelo teste de Greenhouse-Geisse, utilizado-se o comando REPEATED gerado pelo procedimento GLM (PROC GLM do SAS). Análises por tempo somente foram realizadas quando as interações entre tempo e tratamentos foram significativas.

De acordo com os resultados estatísticos obtidos foi possivel obter a equação de superfície gerado pelo procedimento de regressão múltipla (PROC REG), através da metodologia dos quadrados mínimos, onde as variáveis independentes estão representadas pela proporção de concentrados na dieta e dosagem de monensina. O modelo mais complexo que pode ser obtido utilizando esta metodologia ocorre quando há efeito de desvio da linearidade para ambos os fatores e para tal utiliza-se a seguinte equação: $y=b_{0}+b_{1} x_{1}+b_{2} x_{2}+b_{11} x_{1}{ }^{2}+b_{22} x_{2}{ }^{2}+b_{12} x_{1} x_{2}$, onde $y=$ resposta (variável dependente), $b_{i}=$ coeficientes de regressão parcial para cada variável e $x_{i}=$ variáveis independentes (proporção de concentrados e dosagem de monensina). Este procedimento permite variação simultânea de vários fatores para encontrar o nível quantitativo que produz a resposta mais adequada (Roush et al., 1979). Através do procedimento RSREG (PROC RSREG do SAS) foi possivel conhecer a natureza da superfície de resposta, encontrar o ponto estacionário e o valor da variável dependente no ponto estacionário, caso o modelo adotado tenha sido o de desvio da linearidade para 
ambos os fatores e caso o ponto central da superfície esteja dentro dos limites da região experimental.

Utilizou-se nível de significância de 5\% para todos os testes realizados.

Tabela 03. Esquema da análise de variância em delineamento inteiramente casualizado com 7 medidas repetidas no tempo.

\begin{tabular}{|c|c|}
\hline Causas de variação & Graus de Liberdade \\
\hline Tratamentos & 8 \\
\hline Concentrados (Con) & [2] \\
\hline Linear (L) & (1) \\
\hline Desvio (D) & (1) \\
\hline Monensina (Mon) & [2] \\
\hline Linear (L) & (1) \\
\hline Desvio (D) & (1) \\
\hline Interação & [4] \\
\hline $\mathrm{Con}_{\mathrm{L}} \mathrm{X} \mathrm{mon}_{\mathrm{L}}$ & (1) \\
\hline $\mathrm{Con}_{\mathrm{L}} \mathrm{X} \mathrm{mon}_{\mathrm{D}}$ & (1) \\
\hline $\operatorname{Con}_{\mathrm{D}} \mathrm{X} \mathrm{mon}_{\mathrm{L}}$ & (1) \\
\hline $\operatorname{Con}_{\mathrm{D}} \mathrm{X} \mathrm{mon}_{\mathrm{D}}$ & (1) \\
\hline Períodos & 2 \\
\hline Resíduo A & 16 \\
\hline Sub-parcelas & 26 \\
\hline Tempos & 6 \\
\hline Interação Tempo x Tratamento & 48 \\
\hline Interação Tempo x Período & 12 \\
\hline Resíduo B & 96 \\
\hline Total & 188 \\
\hline
\end{tabular}




\subsection{Experimento 2 - Ovinos}

\subsubsection{Animais}

Foram utilizados dezoito carneiros deslanados adultos, machos, mestiços, com peso vivo médio de 56,2 quilos ao início do experimento. Estes eram dóceis o suficiente para permitir a coleta de amostras com mínima interferência sobre o consumo de alimentos.

\subsubsection{Instalações}

Foram utilizadas as instalações do Laboratório de Nutrição de Ruminantes localizado nas dependências da Faculdade de Medicina Veterinária e Zootecnia da USP - Campus de Pirassununga-SP. Os animais foram mantidos em gaiolas metabólicas providas de cocho e bebedouro individuais, sendo os mesmos arreados com bolsas coletoras.

\subsubsection{Tratamentos e delineamento experimental}

Foi utilizado o delineamento inteiramente casualizado (Pimentel Gomes, 1985) com um arranjo fatorial de tratamentos do tipo $2 \times 3$ correspondendo ao fator monensina sódica na dosagem de zero e $40 \mathrm{mg}$ por animal e por dia e três proporções de concentrados na dieta: $25 \%, 50 \%$ e $75 \%$.

Como fonte de monensina sódica foi utilizado o produto comercial Rumensin $\circledast$ (ELANCO), com $10 \%$ de monensina sódica, que foi pesado em balança analítica e acondicionado em envelopes confeccionados em papel. O produto era administrado aos animais durante o momento das refeições, misturados à mistura de concentrados por meio de agitação manual. 
As dietas foram formuladas para serem isonitrogenadas (Tabela 4), sendo o concentrado constituído de grãos de milho moídos, farelo de soja, sal branco e mistura mineral. O volumoso utilizado foi o feno de Coast-cross com aproximadamente 13,0\% de proteína bruta. A ração foi fornecida em duas refeições, às 8:00 e 16:00 h, na forma de mistura completa, sendo compostas as proporções volumoso:concentrados com base na matéria seca. O consumo durante o período de coleta de fezes foi restrito a $80 \%$ do ocorrido ad libitum durante o período de adaptação. Amostras da dieta (feno e misturas concentradas) foram realizadas diariamente durante aquele período, de forma a comporem uma amostra composta.

Tabela 04. Proporções de ingredientes e composição bromatológica das rações utilizadas no experimento com ovinos, com base na matéria seca.

\begin{tabular}{lccc}
\hline & \multicolumn{3}{c}{ Proporção de Concentrados } \\
\hline \multicolumn{1}{c}{ Ingredientes (\%) } & $25 \%$ & $50 \%$ & $75 \%$ \\
\hline Feno de Coast-cross & 75,0 & 50,0 & 25,0 \\
Grãos de milho moídos & 21,6 & 44,7 & 67,7 \\
Farelo de soja & 1,90 & 3,80 & 5,80 \\
Sal branco & 0,50 & 0,50 & 0,50 \\
Mistura mineral ${ }^{1}$ & 1,00 & 1,00 & 1,00 \\
\multicolumn{1}{c}{ Composição } & 100,0 & 100,0 & 100,0 \\
\hline MS (\%) & & & \\
PB (\%) & 91,10 & 90,70 & 90,30 \\
Proteína não degradável (\%) & 12,78 & 13,07 & 13,35 \\
Proteína degradável (\%) & 33,57 & 37,20 & 40,68 \\
FDA (\%) & 66,43 & 62,80 & 59,32 \\
FDN (\%) & 28,46 & 20,90 & 13,35 \\
FDN efetivo (\%) & 58,57 & 45,37 & 32,16 \\
EE (\%) & 55,18 & 38,37 & 21,55 \\
MM (\%) & 1,77 & 2,39 & 3,01 \\
Carboidratos não estrut. (\%) & 8,01 & 6,09 & 4,17 \\
NDT estimado (\%) & 17,87 & 32,08 & 46,30 \\
Ca (\%) & 57,17 & 65,59 & 74,02 \\
P (\%) & 0,55 & 0,49 & 0,42 \\
Col & 0,34 & 0,35 & 0,36 \\
\hline
\end{tabular}

Composição por $\mathrm{kg}$ de mistura mineral: $180 \mathrm{~g} \mathrm{Ca}, 90 \mathrm{~g} \mathrm{P}, 20 \mathrm{~g} \mathrm{Mg}, 20 \mathrm{~g} \mathrm{~S}, 100 \mathrm{~g} \mathrm{Na}, 155 \mathrm{~g} \mathrm{Cl}, 3.000 \mathrm{mg} \mathrm{Zn}$, $1.000 \mathrm{mg} \mathrm{Cu}, 1.250 \mathrm{mg} \mathrm{Mn}, 2.000 \mathrm{mg} \mathrm{Fe}, 100 \mathrm{mg} \mathrm{Co}, 90 \mathrm{mg} \mathrm{I}, 20 \mathrm{mg} \mathrm{Se}, 900 \mathrm{mg}$ F (máximo). 


\subsubsection{Período experimental}

O experimento foi iniciado em 18 de agosto de 1997 e teve duração total de 25 dias, dos quais os primeiros 17 dias foram destinados à adaptação dos animais às dietas. Entre o $18^{\circ}$ e o $25^{\circ}$ dia foi feita a restrição do consumo e entre o $21^{\circ}$ e o $25^{\circ}$ dia a coleta de fezes, urina e ingredientes da dieta para avaliação da digestibilidade in vivo e retenção nitrogenada.

Pesagens dos animais foram realizadas no início e final do experimento e antes da primeira refeição do dia.

As variáveis analisadas foram:

- consumo de matéria seca;

- digestibilidade in vivo da MS e suas frações;

- retenção nitrogenada.

\subsubsection{Descrição das coletas de fezes e urina}

As coletas de fezes, obtidas das bolsas coletoras, foram realizadas uma vez ao dia. Após serem pesadas, uma amostragem de $10 \%$ foi realizada e acondicionada em estufa de ar forçado a $65^{\circ} \mathrm{C}$, permanecendo neste local por 72 horas após a amostragem do último dia de coleta.

A urina foi coletada em baldes plásticos contendo ácido clorídrico concentrado $1: 1$, na proporção de $20 \mathrm{ml}$ de ácido para cada litro de urina produzida durante o período de adaptação. Um amostra referente a $10 \%$ do total produzido foi armazenada sob refrigeração $\left(5^{\circ} \mathrm{C}\right)$ até o momento de realização das análises.

\subsubsection{Métodos analíticos}

As análises bromatológicas de $\mathrm{MS}, \mathrm{PB}, \mathrm{FB}$ e $\mathrm{MM}$ foram realizadas segundo A.O.A.C. (1980) e de FDN e FDA segundo Goering \& Van Soest (1970). 


\subsubsection{Análise estatística}

O tratamento dos dados antes de submetê-los à análise estatística foi semelhante ao realizado no experimento com bovinos. Os efeitos da proporção de concentrados foram separados, arravés do uso de polinômios ortogonais, em efeito linear e desvio da linearidade, enquanto que a interação entre os fatores estudados foi separada através da metodologia de comparação de retas (lineares ou com desvio da linearidade) para o fator presença de monensina (Tabela 5). Para tal análise, também foi utilizado o procedimento General Linear Model (PROC GLM do SAS).

De acordo com os resultados estatísticos obtidos foi possível obter a equação de regressão para efeito da proporção de concentrados. Quando da presença de efeito de interação significativo entre os fatores dose de monensina e proporção de concentrados, indicando diferentes inclinações, foram obtidas diferentes equações de regressão em função da proporção de concentrados, para a presença ou ausência de monensina na dieta.

Utilizou-se nível de significância de $5 \%$ para todos os testes realizados.

Tabela 05. Esquema da análise de variância em delineamento inteiramente casualizado.

\begin{tabular}{|c|c|}
\hline Causas de variação & Graus de Liberdade \\
\hline Tratamentos & 5 \\
\hline Concentrados (Con) & [2] \\
\hline Linear (L) & (1) \\
\hline Desvio (D) & (1) \\
\hline Monensina (Mon) & [1] \\
\hline Interação & [2] \\
\hline $\operatorname{Lin} X \operatorname{lin}$ & (1) \\
\hline Des X des & (1) \\
\hline Resíduo & 12 \\
\hline Total & 17 \\
\hline
\end{tabular}




\section{RESULTADOS E DISCUSSÃO}

\subsection{Consumo de matéria seca}

Os efeitos da proporção de concentrados na dieta e da dose de monensina sobre o consumo de MS por animal por dia, consumo de MS por quilo de peso vivo e consumo de MS por quilo de peso metabólico $\left(\mathrm{P}^{0,75}\right)$ do experimento com bovinos e ovinos encontram-se nas Tabelas 6 e 8 , respectivamente.

O nível de fibra da dieta ou dose de monensina não influenciaram o consumo de MS por animal por dia no experimento com bovinos, mas quando esta variável foi ajustada, seja pelo peso vivo ou pelo peso metabólico dos animais, interagiram de forma que a proporção de concentrados causou uma resposta curvilinear, com maior consumo em dietas mistas, e a monensina uma resposta linear, diminuindo o consumo (Figura 1). Entretanto, observou-se que em animais recebendo dietas predominantemente concentradas ou predominantemente volumosas, doses altas de monensina resultaram em maiores consumos. No experimento com ovinos, não foi possível detectar efeitos significativos dos tratamentos sobre o consumo de matéria seca, em nenhuma das maneiras que os dados fossem expressos.

Diminuição de até $33,0 \%$ causada pela monensina sobre o consumo de alimentos corrigidos para o peso vivo ou peso metabólico observado no experimento com bovinos, em animais recebendo dieta mista, é bastante alto quando comparado com o valor médio da ordem de $6,4 \%$ encontrado por Goodrich et al. (1984), em extensa revisão do assunto. Os dados do presente trabalho parecem concordar com os obtidos por Arcaro (1998) de que os ionóforos deprimem mais o consumo em dietas mistas, 
quando comparada com as predominantemente volumosa. Entretanto, não permitem confirmar a hipótese postulada por Schelling (1984) de que os ionóforos deprimem o consumo voluntário de alimentos quando os animais são alimentados com dietas predominantemente concentradas, mas podem incrementar o consumo em condições de pastejo. Nem tão pouco aquela postulada por Baile et al. (1979), os quais afirmaram que os ionóforos reduzem o consumo de alimentos em qualquer tipo de dieta, embora com maiores efeitos em dietas predominantemente concentradas.

Entretanto, em ambos os experimentos aqui realizados, embora no experimento com carneiros não tenha sido estatisticamente significativo, a monensina pouco alterou o consumo na dieta predominantemente volumosa, diminuiu bastante $o$ consumo na dieta mista, e aparentemente não alterou ou mesmo voltou a aumentar o consumo na dieta predominantemente concentrada. Portanto, é bem provável que a monensina deprima mais o consumo em dietas concentradas, como postulado por Schelling (1984) e Baile et al. (1979), mas se esta dieta for excessivamente concentrada, e potencialmente acidogênica, é possivel que esse produto melhore as condições de fermentação ruminal nestas condições, permitindo maior consumo. Entretanto, neste caso, há que se considerar que em dietas altamente energéticas o consumo seja mais influenciado por aspectos fisiopatológicos ( $\mathrm{pH}$ ruminal excessivamente baixo) do que pela produção de ácido propiônico (disparador do gatilho da saciedade em ruminantes).

De forma geral, os resultados aqui observados com bovinos parecem concordar com aqueles obtidos por Lemenager et al. (1978), McCartor et al. (1979), Tumer et al. (1980), Beede et al. (1986a), Sauer et al. (1989), Weiss \& Amiet (1990), Santos (1991) e Sauer et al. (1997) os quais tem demonstrado diminuição na ingestão de MS com o uso de ionóforos, enquanto que os dados com ovinos concordam com muitos outros que não observaram efeitos dos ionóforos sobre o consumo de alimentos nas mais diversas condições (Dinius et al., 1976; Hanson \& Klopfenstein, 1979; Horton et al., 1980; Ricke et al., 1984; Brown \& Hogue, 1985; Jacques et al., 1987; Beacom et al., 1988; Dye et al., 1988; Branine \& Galyean, 1990; Bem, 1991; Gomez et al., 1991; Sip et al., 1991; Ivan et al., 1992; Steen et al., 1992; Clary et al., 1993; Galloway et al., 1993; 
Fredrickson et al., 1993; Yang \& Russell, 1993; Zinn \& Borques, 1993; Vagnoni et al., 1995; Knowlton et al., 1996a; Wessels et al., 1996; Castro, 1998). Zinn et al. (1994), Rodrigues (1996) e Ramanzin et al. (1997) ainda afirmam que a ausência de resposta independe da proporção de concentrados da dieta.

A resposta curvilinear observada para o consumo, quando expresso em função do peso vivo ou metabólico, causada pela variação na proporção de concentrados da dieta utilizada no experimento com bovinos foi muito bem relatada pelo clássico trabalho de Conrad et al. (1964), os quais demostraram ser positiva a correlação entre o conteúdo de energia disponível e a quantidade ingerida, em se tratando de volumosos de baixa a média qualidade (teoria do enchimento), e ser negativa, com volumosos de alta qualidade e dietas a base de grãos (teoria quimiostática). 
Tabela 06. Efeitos da proporção de concentrados (Con) e dose de monensina (Mon) sobre o consumo diário de matéria seca (CMS), em quilos, consumo diário de matéria seca por quilo de peso vivo (CMS/ $\mathrm{kgPV})$, em porcentagem do peso vivo, e consumo diário de matéria seca por quilo de peso metabólico $\left(\mathrm{CMS} / \mathrm{kgP}^{0,75}\right)$, em gramas, coeficientes de variação $(\mathrm{CV})$ e probabilidades estatísticas no experimento com bovinos.

\begin{tabular}{|c|c|c|c|c|}
\hline \multicolumn{2}{|c|}{ Tratamentos } & \multicolumn{3}{|c|}{ Consumos } \\
\hline Con & Mon & CMS & $\mathrm{CMS} / \mathrm{kgPV}$ & $\mathrm{CMS} / \mathrm{kgP}^{0,75}$ \\
\hline \multicolumn{5}{|c|}{ Interações } \\
\hline \multirow{3}{*}{25} & 0 & 8,50 & 1,75 & 81,91 \\
\hline & 150 & 8,67 & 1,58 & 76,45 \\
\hline & 300 & 9,52 & 1,85 & 87,70 \\
\hline \multirow{3}{*}{50} & 0 & 12,96 & 2,52 & 119,86 \\
\hline & 150 & 10,33 & 2,18 & 111,61 \\
\hline & 300 & 8,84 & 1,67 & 80,01 \\
\hline \multirow{3}{*}{75} & 0 & 9,86 & 1,84 & 88,59 \\
\hline & 150 & 9,55 & 1,79 & 85,78 \\
\hline & 300 & 10,49 & 2,15 & 100,80 \\
\hline \multicolumn{5}{|c|}{ Efeitos Principais } \\
\hline 25 & & 8,90 & 1,73 & 82,05 \\
\hline 50 & & 10,71 & 2,12 & 100,49 \\
\hline \multirow[t]{4}{*}{75} & & 9,97 & 1,93 & 91,72 \\
\hline & 0 & 10,44 & 2,04 & 96,79 \\
\hline & 150 & 9,52 & 1,85 & 87,95 \\
\hline & 300 & 9,62 & 1,89 & 89,53 \\
\hline \multicolumn{5}{|c|}{ Dados Médios } \\
\hline \multirow{2}{*}{\multicolumn{2}{|c|}{$\begin{array}{l}\text { Média } \\
\text { CV }\end{array}$}} & 9,86 & 1,93 & 91,42 \\
\hline & & 25,88 & 21,15 & 21,6 \\
\hline \multicolumn{5}{|c|}{ Probabilidades Estatísticas } \\
\hline \multicolumn{5}{|l|}{ Concentrado } \\
\hline Linear (L) & & NS & NS & NS \\
\hline Desvio (D) & & NS & NS & NS \\
\hline \multicolumn{5}{|l|}{ Monensina } \\
\hline Linear (L) & & NS & NS & NS \\
\hline Desvio (D) & & NS & NS & NS \\
\hline \multicolumn{5}{|l|}{ Interação } \\
\hline $\operatorname{Con}_{\mathrm{L}} \mathrm{X} \operatorname{mon}_{\mathrm{L}}$ & & NS & NS & NS \\
\hline $\mathrm{Con}_{\mathrm{L}} \mathrm{X} \mathrm{mon}_{\mathrm{D}}$ & & NS & NS & NS \\
\hline $\operatorname{Con}_{\mathrm{D}} \mathrm{X} \mathrm{mon}_{\mathrm{L}}$ & & NS & 0,0126 & 0,0193 \\
\hline $\mathrm{Con}_{\mathrm{D}} \mathrm{X} \mathrm{mon}_{\mathrm{D}}$ & & NS & NS & NS \\
\hline
\end{tabular}




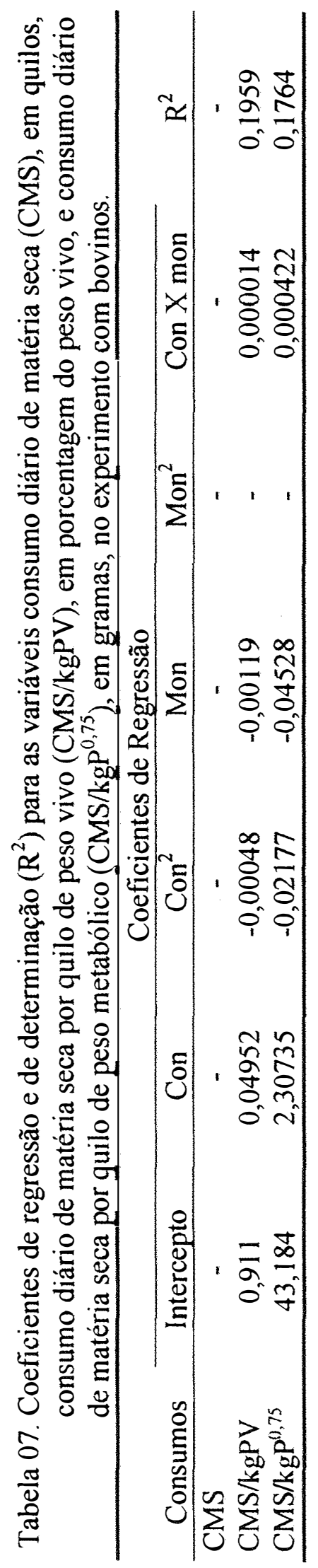



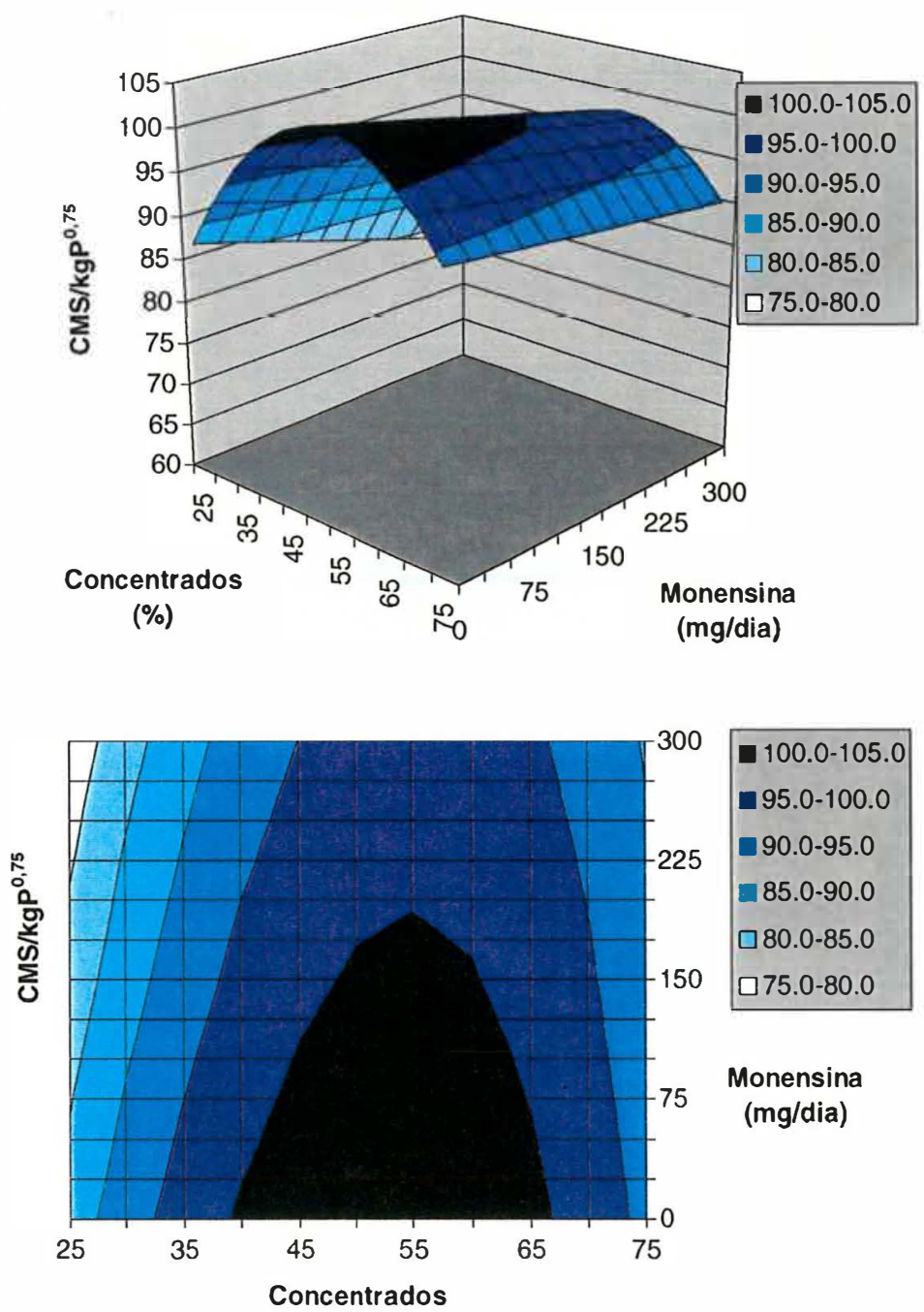

$(\%)$

Figura 01 - Efeitos da proporção de concentrados (\% da dieta) e dose de monensina (mg/animal/dia) sobre consumo diário de matéria seca por quilo de peso metabólico $\left(\mathrm{CMS} / \mathrm{kgP}^{0,75}\right)$, em gramas, no experimento com bovinos. 
Tabela 08. Efeitos da proporção de concentrados (Con) e dose de monensina (Mon) sobre o consumo diário de matéria seca (CMS), em quilos, consumo diário de matéria seca por quilo de peso vivo (CMS/ $\mathrm{kgPV})$, em porcentagem do peso vivo, e consumo diário de matéria seca por quilo de peso metabólico $\left(\mathrm{CMS} / \mathrm{kgP}^{0,75}\right)$, em gramas, coeficientes de variação $(\mathrm{CV})$ e probabilidades estatísticas no experimento com ovinos.

\begin{tabular}{|c|c|c|c|c|}
\hline \multicolumn{2}{|c|}{ Tratamentos } & \multicolumn{3}{|c|}{ Consumos } \\
\hline Con & Mon & CMS & $\mathrm{CMS} / \mathrm{kgPV}$ & ${\mathrm{CMS} / \mathrm{kgP}^{0,75}}^{0.75}$ \\
\hline \multicolumn{5}{|c|}{ Interações } \\
\hline \multirow[t]{2}{*}{25} & 0 & 1,08 & 2,05 & 55,09 \\
\hline & 40 & 1,17 & 1,98 & 54,75 \\
\hline \multirow[t]{2}{*}{50} & 0 & 1,20 & 2,39 & 63,64 \\
\hline & 40 & 0,76 & 1,39 & 37,75 \\
\hline \multirow[t]{2}{*}{75} & 0 & 1,32 & 2,46 & 66,64 \\
\hline & 40 & 1,38 & 2,39 & 65,92 \\
\hline \multicolumn{5}{|c|}{ Efeitos Principais } \\
\hline 25 & & 1,13 & 2,00 & 54,89 \\
\hline 50 & & 0,98 & 1,89 & 50,70 \\
\hline \multirow[t]{3}{*}{75} & & 1,35 & 2,43 & 66,28 \\
\hline & 0 & 1,22 & 2,33 & 62,63 \\
\hline & 40 & 1,10 & 1,92 & 52,81 \\
\hline \multicolumn{5}{|c|}{ Dados Médios } \\
\hline \multirow{2}{*}{\multicolumn{2}{|c|}{$\begin{array}{l}\text { Média } \\
\text { CV }\end{array}$}} & 1,16 & 2,11 & 57,43 \\
\hline & & 28,91 & 25,77 & 26,22 \\
\hline \multicolumn{5}{|c|}{ Probabilidades Estatísticas } \\
\hline \multicolumn{5}{|l|}{ Concentrado } \\
\hline Linear $(L)$ & & NS & NS & NS \\
\hline Desvio (D) & & NS & NS & NS \\
\hline Monensina & & NS & NS & NS \\
\hline \multicolumn{5}{|l|}{ Interação } \\
\hline Linear X linear & & NS & NS & NS \\
\hline Desvio $\mathrm{X}$ desvio & & NS & NS & NS \\
\hline
\end{tabular}




\section{$5.2 \mathrm{pH}$ do conteúdo ruminal}

Os valores do $\mathrm{pH}$ ruminal obtidos nos diversos tempos de amostragem do experimento com bovinos encontram-se na Tabela 9. Embora os tratamentos utilizados neste experimento tenham interagido com o fator tempo de amostragem, ao ser realizada a análise estatística em cada tempo observou-se o mesmo perfil de resposta para todas as horas amostradas, excetuando para as 4 horas, indicando diferenças na magnitude da resposta entre os tempos, mas não no seu padrão. Tomando-se o pH médio ao longo do período amostral, o nível de fibra da dieta e dose de monensina interagiram de forma que a proporção de concentrados causou uma resposta linear, observando-se aumento do $\mathrm{pH}$ com o aumento no nível de fibra da dieta, e a monensina uma resposta curvilinear, aumentando o pH com doses intermediárias (Figura 2). A resposta à utilização de monensina foi nula em dietas predominantemente volumosas (aumento de $-1,6 \%$ e 1,0\% ou $-0,11$ e 0,07 unidades de $\mathrm{pH}$ ), baixas em dietas mistas (aumento de $2,8 \%$ e $2,0 \%$ ou 0,18 e 0,13 unidades de $\mathrm{pH}$ ) e maiores (aumento de $7,8 \%$ e $4,1 \%$ ou 0,47 e 0,25 unidades de $\mathrm{pH}$ ) em dietas predominantemente concentradas, sendo as maiores respostas obtidas nesta condição com a utilização de doses intermediárias do produto.

Os dados do presente experimento são compatíveis com os obtidos por Horton et al. (1980), Brown \& Hogue (1985), Katz et al. (1986), Branine \& Galyean (1990), Ivan et al. (1992), Vagnoni et al. (1995), Salles (1997), Suber \& Bowman (1998) e Green et al. (1999), os quais observaram que a monensina aumentava o $\mathrm{pH}$ do líquido ruminal ou meio de cultura, dependendo da metodologia experimental.

Entretanto, não se pode dizer que são diferentes dos obtidos por Paterson et al. (1983), Jacques et al. (1987), Da Silva (1990), bogaert et al. (1991), Francisco Jr. (1994), Knowlton et al. (1996b), Wessels et al. (1996), Castro (1998) e Amaro (1999) ao utilizarem a lasalocida; Dinius et al. (1976), Poos et al. (1979), Rogers \& Davis (1982), Fredrickson et al. (1993), Yang \& Russell (1993), Zinn \& Borques (1993) e Haimoud et al. (1995) ao utilizarem a monensina; Darden et al. (1985) ao utilizarem a monensina ou 
lasalocida ou, ainda, Morris et al. (1990) e Clary et al. (1993) ao utilizarem a lasalocida ou monensina mais tilosina, ao não demonstrarem efeito dos produtos testados sobre o pH ruminal. Curiosamente, Beacom et al. (1988) e Zinn et al. (1994) demonstraram que a lasalocida e a monensina diminuíram, respectivamente, o $\mathrm{pH}$ ruminal em bovinos recebendo dieta rica em concentrados, enquanto que Lana \& Russell (1997) mostraram que a monensina também diminuiu o $\mathrm{pH}$ em animais alimentados apenas com volumosos.

Embora a literatura careça de informações quanto ao efeito das condições de fermentação ruminal sobre a resposta dos ionóforos sobre o $\mathrm{pH}$ ruminal, Schelling (1984) sugeriu que, sob excesso de carboidratos rapidamente fermentesciveis, os ionóforos aumentam o $\mathrm{pH}$ e diminuem as concentrações de lactato no rúmen, enquanto que na ausência desses carboidratos, os ionóforos poderiam não alterar o $\mathrm{pH}$ ruminal e até aumentar as concentrações de ácido lático. Da mesma forma, Wampler et al. (1998) demonstraram em experimentos in vitro que a monensina era mais potente em diminuir o crescimento de Streptococcus bovis, com conseqüente diminuição da produção de ácido lático, quando o $\mathrm{pH}$ do meio de cultura era mais baixo (5,7 versus 6,7$)$. Os resultados encontrados no presente experimento confirmam os achados acima de que a resposta do $\mathrm{pH}$ ruminal à presença da monensina é dependente das condições de fermentação ruminal. Torna-se importante acrescentar que não apenas as condições de fermentação ruminal, mas também a dose do produto influenciam na resposta alcançada.

É possivel que os trabalhos de Zinn et al. (1994) e Ramanzin et al. (1997) não tivessem alcançado um universo de estudo tão abrangente quanto ao observado no presente experimento, já que aqueles autores não observaram efeitos da monensina sobre o $\mathrm{pH}$ do líquido ruminal, independentemente da dieta utilizada, quando o primeiro utilizou este produto em novilhos alimentados com $10 \%$ ou $20 \%$ de volumosos e o segundo quando alimentou vacas com dietas contendo $30 \%$ ou $50 \%$ de concentrados.

O aumento da proporção de concentrados na dieta causou decréscimo do $\mathrm{pH}$ do líquido ruminal em até $9,6 \%$, em média, sendo este decréscimo maior quanto 
menor a dose de monensina adicionada à dieta. Também o tempo de amostragem do $\mathrm{pH}$ ruminal foi significativo $(\mathrm{P}<0,0001)$, de forma que o menor $\mathrm{pH}$ foi observado 6 horas após a administração da alimentação e, mesmo após a $2^{\mathrm{a}}$ hora, $\mathrm{o} \mathrm{pH}$ do líquido ruminal já se apresentava inferior ao valor de 6,7 recomendado por Mould et al. (1983) para não haver queda na taxa de degradação da fibra. 
Tabela 09. Efeitos da proporção de concentrados (Con) e dose de monensina (Mon) sobre o $\mathrm{pH}$ do líquido ruminal, em diferentes horas de amostragem, coeficientes de variação $(\mathrm{CV})$ e probabilidades estatísticas no experimento com bovinos.

\begin{tabular}{|c|c|c|c|c|c|c|c|c|c|}
\hline \multicolumn{2}{|c|}{ Tratamentos } & \multicolumn{7}{|c|}{ Tempo (horas) } & \multirow[b]{2}{*}{ Média } \\
\hline Con & Mon & 0 & 2 & 4 & 6 & 8 & 10 & 12 & \\
\hline \multicolumn{10}{|c|}{ Interações } \\
\hline \multirow{3}{*}{25} & 0 & 6,74 & 6,72 & 6,70 & 6,72 & 6,78 & 6,80 & 6,84 & 6,76 \\
\hline & 150 & 6,63 & 6,66 & 6,67 & 6,64 & 6,61 & 6,63 & 6,72 & 6,65 \\
\hline & 300 & 6,88 & 6,80 & 6,75 & 6,77 & 6,86 & 6,88 & 6,88 & 6,83 \\
\hline \multirow{3}{*}{50} & 0 & 6,58 & 6,43 & 6,42 & 6,27 & 6,38 & 6,46 & 6,56 & 6,44 \\
\hline & 150 & 6,73 & 6,58 & 6,54 & 6,50 & 6,57 & 6,65 & 6,75 & 6,62 \\
\hline & 300 & 6,77 & 6,56 & 6,48 & 6,38 & 6,49 & 6,64 & 6,64 & 6,57 \\
\hline \multirow{3}{*}{75} & 0 & 6,36 & 6,11 & 6,00 & 5,83 & 5,99 & 6,22 & 6,24 & 6,11 \\
\hline & 150 & 6,83 & 6,55 & 6,42 & 6,35 & 6,57 & 6,64 & 6,74 & 6,58 \\
\hline & 300 & 6,80 & 6,24 & 6,11 & 6,08 & 6,25 & 6,45 & 6,59 & 6,36 \\
\hline \multicolumn{10}{|c|}{ Efeitos Principais } \\
\hline 25 & & 6,75 & 6,72 & 6,71 & 6,71 & 6,75 & 6,77 & 6,81 & 6,75 \\
\hline 50 & & 6,69 & 6,52 & 6,48 & 6,38 & 6,48 & 6,59 & 6,65 & 6,54 \\
\hline \multirow[t]{4}{*}{75} & & 6,66 & 6,30 & 6,18 & 6,08 & 6,27 & 6,44 & 6,52 & 6,35 \\
\hline & 0 & 6,56 & 6,62 & 6,38 & 6,27 & 6,38 & 6,49 & 6,55 & 6,44 \\
\hline & 150 & 6,73 & 6,60 & 6,54 & 6,49 & 6,58 & 6,64 & 6,74 & 6,62 \\
\hline & 300 & 6,82 & 6,53 & 6,45 & 6,41 & 6,53 & 6,66 & 6,70 & 6,59 \\
\hline \multicolumn{10}{|c|}{ Dados Médios } \\
\hline \multirow{2}{*}{\multicolumn{2}{|c|}{$\begin{array}{l}\text { Média } \\
C V\end{array}$}} & 6,70 & 6,52 & 6,46 & 6,39 & 6,50 & 6,60 & 6,66 & 6,55 \\
\hline & & 3,61 & 3,90 & 4,62 & 5,29 & 4,81 & 4,24 & 3,77 & 4,56 \\
\hline \multicolumn{10}{|c|}{ Probabilidades Estatísticas } \\
\hline \multicolumn{10}{|c|}{ Concentrado } \\
\hline \multicolumn{2}{|c|}{ Linear (L) } & NS & 0,0001 & 0,0001 & 0,0001 & 0,0001 & 0,0039 & 0,0020 & 0,0002 \\
\hline \multicolumn{2}{|c|}{ Desvio (D) } & NS & NS & NS & NS & NS & NS & NS & NS \\
\hline \multicolumn{10}{|c|}{ Monensina } \\
\hline \multicolumn{2}{|c|}{ Linear $(\mathrm{L})$} & 0,0064 & NS & NS & NS & NS & NS & NS & NS \\
\hline \multicolumn{2}{|c|}{ Desvio (D) } & NS & NS & NS & NS & NS & NS & NS & NS \\
\hline \multicolumn{10}{|c|}{ Interação } \\
\hline Con & $\operatorname{mon}_{\mathrm{L}}$ & NS & NS & NS & NS & NS & NS & NS & NS \\
\hline Con & $\operatorname{mon}_{D}$ & 0,0238 & 0,0112 & NS & 0,0222 & 0,0031 & 0,0259 & 0,0125 & 0,0115 \\
\hline Con & $\operatorname{mon}_{\mathrm{L}}$ & NS & NS & NS & NS & NS & NS & NS & NS \\
\hline Con & mon $_{D}$ & NS & NS & NS & NS & NS & NS & NS & NS \\
\hline
\end{tabular}


Tabela 09. Efeitos da proporção de concentrados (Con) e dose de monensina (Mon) sobre o $\mathrm{pH}$ do líquido ruminal, em diferentes horas de amostragem, coeficientes de variação $(\mathrm{CV})$ e probabilidades estatísticas no experimento com bovinos.

\begin{tabular}{|c|c|}
\hline Causas de variação & $\begin{array}{l}\text { Probabilidades } \\
\text { Estatísticas }\end{array}$ \\
\hline Tempo & 0,0001 \\
\hline Tempo X concentrado (Con) & \\
\hline Tempo X con Linear & 0,0001 \\
\hline Tempo X con Desvio & NS \\
\hline Tempo X monensina (Mon) & \\
\hline Tempo X mon Linear & 0,0186 \\
\hline Tempo X mon Desvio & NS \\
\hline Tempo $\mathrm{X}$ concentrado $\mathrm{X}$ monensina & \\
\hline Tempo X con cinear $\mathrm{X}$ mon $_{\text {Linear }}$ & NS \\
\hline Tempo $X$ con $_{\text {Linear }} \mathrm{X}$ mon $_{\text {Desvio }}$ & NS \\
\hline Tempo $X$ con $_{\text {Desvio }} \mathrm{X}$ mon $_{\text {Linear }}$ & NS \\
\hline Tempo $X$ con $_{\text {Desvio }} X$ mon $_{\text {Desvio }}$ & NS \\
\hline
\end{tabular}




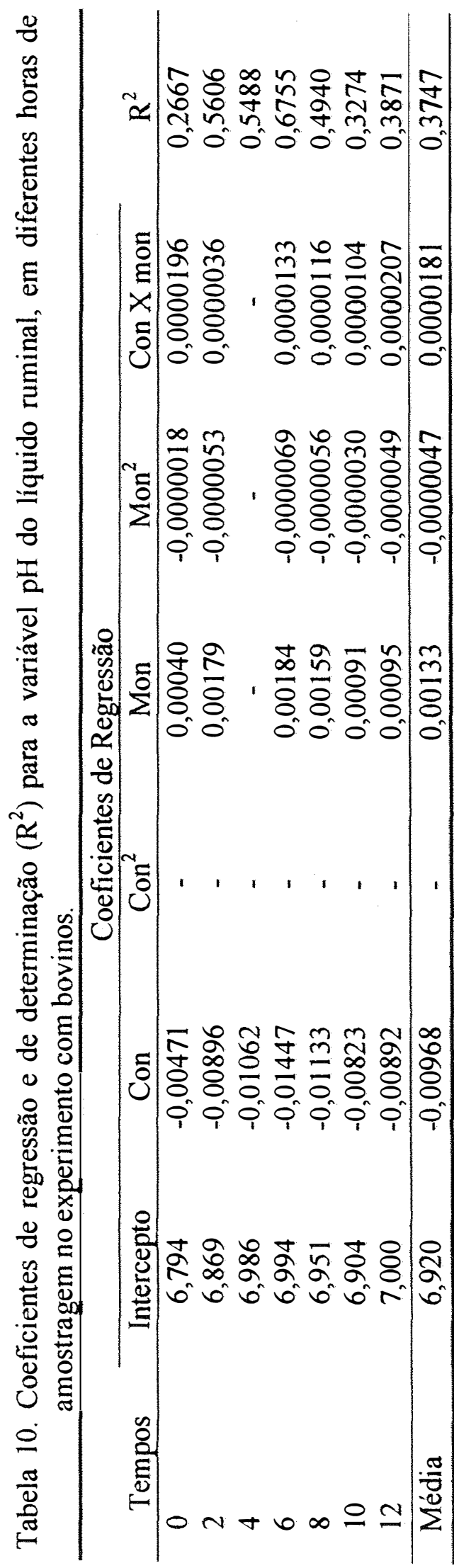



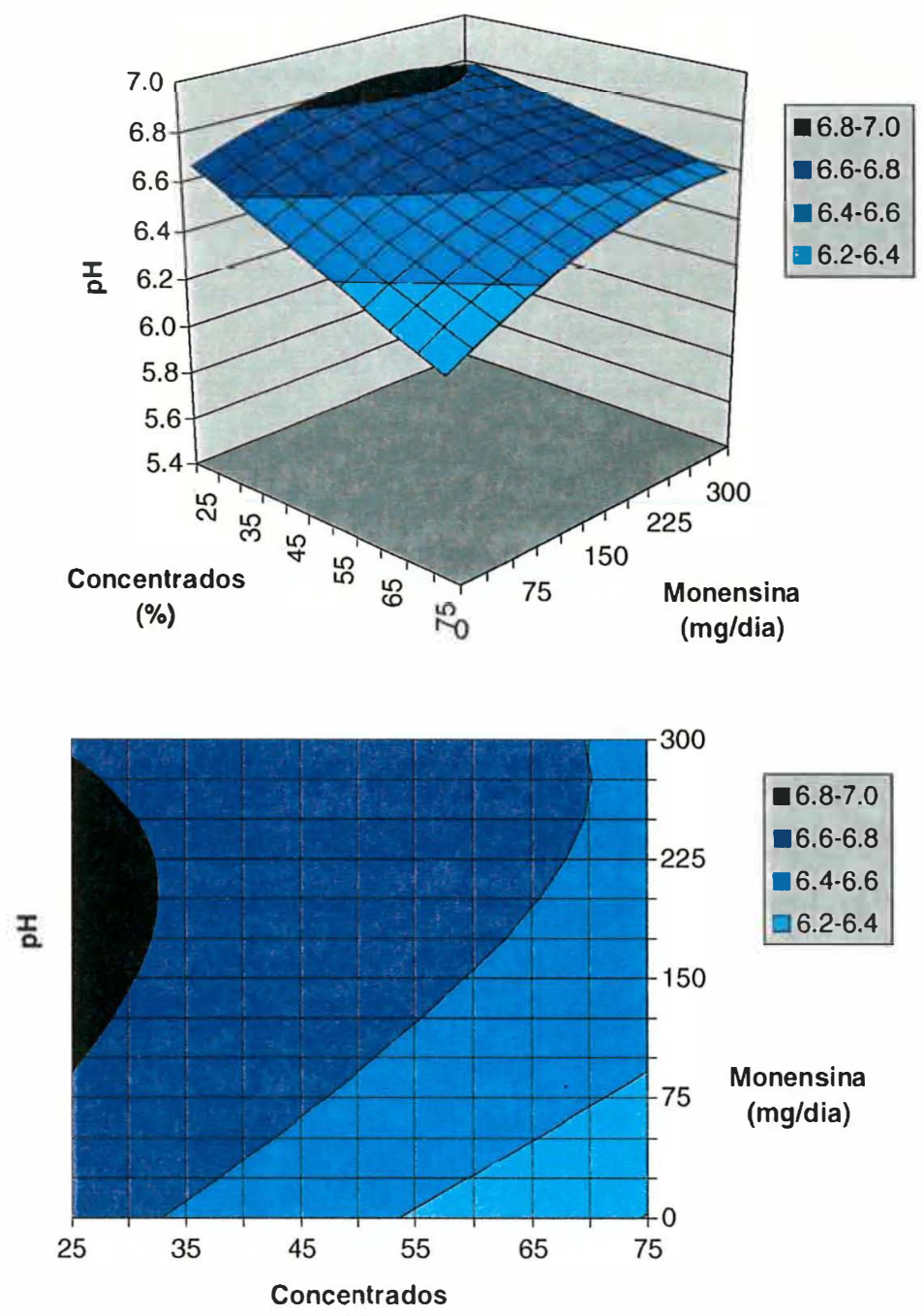

(\%)

Figura 02 - Efeitos da proporção de concentrados (\% da dieta) e dose de monensina ( $\mathrm{mg} /$ animal/dia) sobre o $\mathrm{pH}$ médio do líquido ruminal, entre as diferentes horas de amostragem, obtidos no experimento com bovinos. 


\subsection{Proporção molar de AGVs no líquido ruminal}

As concentrações totais de AGVs maiores $\left(C_{2}+C_{3}+C_{4}\right)$, as proporções molares de acetato $\left(C_{2}\right)$, propionato $\left(C_{3}\right)$, butirato $\left(C_{4}\right)$ e relações acetato:propionato do experimento com bovinos encontram-se respectivamente nas Tabelas 11, 13, 15, 17 e 19.

Os tratamentos apresentaram interação com tempo para a concentração total dos AGVs $\left(C_{2}+C_{3}+C_{4}\right)$. Quando analisados separadamente observou-se interação entre os fatores níveis de monensina e proporção de concentrados na dieta para a amostragem realizada na hora zero, de forma que a depressão deste parâmetro foi maior quanto maior a dose de monensina e maior a proporção de concentrados. Para as amostragens realizadas às 2 e 4 horas observou-se efeito curvilinear da monensina em diminuir as concentrações totais em dosagens intermediárias do produto, independentemente da dieta utilizada. $O$ aumento da proporção de concentrados aumentou a concentração total de AGVs nas horas 2, 4 e 6 após a alimentação.

Os dados deste experimento concordam com os obtidos por Lemenager et al. (1978), Machado (1988), Hino et al. (1994) e Vagnoni et al. (1995), com monensina, e Dye et al. (1988), com lasalocida, em que tais produtos diminuem a concentração total de AGVs, embora outros não tenham observado efeito com a monensina (Dinius et al., 1976; Davis \& Erhart, 1976; McCartor et al., 1979; Thornton \& Owens, 1981; Branine \& Galyean, 1990; Yang \& Russell, 1993; Haimoud et al., 1995; Knowlton et al., 1996b; Ramanzin et al., 1997; Suber \& Bowman, 1998; Green et al., 1999); lasalocida (Funk et al., 1986; Reffett-Stabel et al., 1989; Da Silva, 1990; Francisco Jr., 1994; Wessels et al., 1996; Castro, 1998; Amaro, 1999) e lasalocida ou monensina (Katz et al., 1986; Clary et al., 1993). Hanson \& Klopfenstein (1979) e Callaway \& Martin (1997) observaram, ainda, que a monensina aumentou a concentração total de AGVs, sendo que Rogers \& Davis (1982) também observaram tal efeito com este produto, ao corrigir a produção de AGVs para a quantidade de MS consumida. 
Para as variáveis proporção molar de acetato, propionato e relação acetato:propionato observou-se interação entre efeitos de tratamento e tempo de amostragem. Ao analisar cada tempo separadamente, as probabilidades estatísticas apresentaram os mesmos padrões de resposta aos tratamentos em todos os diferentes tempos, ou seja, níveis de monensina e proporção de concentrados interagiram, sendo a resposta à monensina do tipo curvilinear e ao concentrado do tipo linear.

Tomando-se a média dos tempos amostrados, a adição de doses elevadas de monensina aumentou a proporção molar de propionato em até 3,5 unidades percentuais $(25,4 \%)$ na dieta predominantemente volumosa, 4,4 unidades $(26,4 \%)$ na dieta mista e 12,6 unidades $(50,0 \%)$ na dieta predominantemente concentrada, embora doses intermediárias do produto tenham diminuído em 4,9 unidades $(19,6 \%)$ a proporção molar de propionato somente nesta mesma dieta (Figura 5). Padrões semelhantes de resposta, mas numericamente inversa, foram observados para a proporção molar de acetato (Figura 3) e relação acetato:propionato (Figura 9).

Para a proporção molar de butirato, excetuando a $12^{\mathrm{a}}$ hora, todas as demais também apresentaram interação entre os fatores estudados, sendo ambas as respostas para níveis de monensina e proporção de concentrados do tipo linear (Figura 7). Em média, dosagens altas de monensina aumentaram a proporção molar de butirato em até 0,4 unidades percentuais $(6,1 \%)$ nas dietas predominantemente volumosas, mas diminuíram este valor em até 2,5 unidades $(25,0 \%)$ nas dietas mistas e 3,6 unidades $(38,7 \%)$ nas predominantemente concentradas.

Os resultados do presente experimento concordam parcialmente com os obtidos por vários pesquisadores que registraram aumento do propionato em detrimento do acetato e/ou butirato com o uso de ionóforos na dieta, qualquer que fosse sua composição (Dinius et al., 1976; Lemenager et al., 1978; Hanson \& Klopfenstein, 1979; McCartor et al., 1979; Ricke et al., 1984; Machado, 1988; Reffett-Stabel et al., 1989; Galloway et al., 1993; Yang \& Russell, 1993; Hino et al., 1994; Duff et al., 1995; Haimoud et al., 1995; Vagnoni et al., 1995; Callaway \& Martin, 1997; Sauer et al., 1997; Suber \& Bowman, 1998). Entretanto, outros não observaram efeito algum com o 
uso de ionóforos sobre estes parâmetros (Francisco Jr., 1994; Castro, 1998; Amaro, 1999)

Observando-se os dados do presente experimento sob uma perspectiva diferente observou-se que, não somente os efeitos da monensina sobre a proporção molar de AGVs variam com o nível de fibra na dieta, mas também que o efeito que o nível de fibra causou sobre esta variável depende da dose de monensina utilizada (Figuras 4, 6, 8 e 10). Utilizando-se doses baixas de monensina (150 mg/animal/dia), os aumentos alcançados sobre a proporção molar de propionato foram maiores, quanto menor foi a proporção de concentrados na dieta (aumentos de 2,85, 1,34 e -4,93 unidades percentuais de propionato para dietas com $25 \%, 50 \%$ e $75 \%$ de concentrados, respectivamente). Já com doses altas do produto (300 mg/animal/dia), as melhores respostas à monensina ocorreram nas dietas com maior proporção de concentrados (aumentos de 3,51, 4,39 e 12,55 unidades percentuais de propionato para dietas com $25 \%, 50 \%$ e $75 \%$ de concentrados, respectivamente). Portanto, ora dietas mais concentradas podem apresentar maiores respostas, ora dietas mais volumosas podem apresentar os melhores resultados com a utilização de monensina, sendo a dose do produto identificada como um "divisor de águas" neste experimento.

Pode-se inferir que os dados do presente experimento concordam com os obtidos por Richardson et al. (1976) ao observarem efeitos da monensina em alterar a proporção molar de AGVs em ensaios in vitro quando era utilizado inóculo de animais alimentados com dietas concentradas, porém com inóculos de animais recebendo dietas ricas em alimentos volumosos, esses efeitos somente foram observados ao serem aumentadas as concentrações do produto. Também concordam com Rodrigues (1996) que observou interação entre dose de ionóforo (lasalocida) e nível de fibra na dieta. Embora o efeito da lasalocida não fosse significativo, este autor demonstrou que o nível de fibra alterou a proporção molar dos AGVs no líquido ruminal na presença do ionóforo, mas não na sua ausência. Concorda ainda com Ramanzin et al. (1997) que também observaram maiores efeitos da monensina sobre a proporção molar de AGVs em vacas leiteiras submetidas a dietas com $50 \%$ de concentrados do que quando estas 
recebiam dietas com apenas 30\% de concentrados. Da mesma forma, Zinn et al. (1994) observaram efeitos positivos nas dietas mais concentradas e negativos quando se aumentou a proporção de volumosos.

Entretanto, não se pode afirmar que os dados presentes discordam de Thorton \& Owens (1981), os quais registraram maior aumento na proporção molar de propionato, ao utilizarem a monensina, em dietas com altos níveis de fibra (40\% de FDA) do que com baixos (12\% de FDA), ou dos dados de Da Silva (1990), que somente observou efeito da lasalocida sobre a proporção molar de ácidos graxos voláteis após a associação deste produto com bicarbonato de sódio. Nem tão pouco são diferentes dos obtidos por Garcia-Lopez et al. (1996) que demonstraram in vitro que a monensina aumentou a concentração de propionato nas dietas mistas ( $50 \%$ de concentrados) e volumosas ( $0 \%$ de concentrados), mas não nas concentradas ( $90 \%$ de concentrados).

A utilização de um universo amostral maior no presente experimento, no qual o produto foi testado em diferentes doses e diferentes composições da dieta, permite concluir que respostas aparentemente discordantes encontradas na literatura não passam de um mesmo contínuo de resposta em função de dois diferentes fatores: dose do produto e condição de fermentação ruminal.

Cabe lembrar ainda que a grandeza dos efeitos da monensina foram menores em dietas predominantemente volumosas e, nessas condições, doses baixas do produto já seriam suficientes para desencadear respostas máximas ou próximas a elas. Já em dietas predominantemente concentradas, as respostas foram maiores, quando comparadas com as respostas obtidas em dietas predominantemente volumosas, embora fossem necessárias doses bem maiores do produto para desencadear a resposta nessas condições.

Partindo-se do pressuposto que o número de bactérias é maior em dietas predominantemente concentradas (Leedle \& Hespell, 1980), os dados aqui obtidos in vivo substanciam a afirmação de Chow \& Russell (1990), obtida in vitro, de que relação a entre dose do ionóforo e massa microbiana ruminal é mais importante do que a concentração absoluta do produto. 
Tabela 11. Efeitos da proporção de concentrados (Con) e dose de monensina (Mon) sobre as concentrações de AGVs maiores $\left(\mathrm{C}_{2}+\mathrm{C}_{3}+\mathrm{C}_{4}\right)$ no líquido ruminal $(\mathrm{mM})$, em diferentes horas de amostragem, coeficientes de variação $(\mathrm{CV})$ e probabilidades estatísticas no experimento com bovinos.

\begin{tabular}{|c|c|c|c|c|c|c|c|c|c|}
\hline \multicolumn{2}{|c|}{ Tratamentos } & \multicolumn{7}{|c|}{ Tempo (horas) } & \multirow[b]{2}{*}{ Média } \\
\hline Con & Mon & 0 & 2 & 4 & 6 & 8 & 10 & 12 & \\
\hline \multicolumn{10}{|c|}{ Interações } \\
\hline \multirow{3}{*}{25} & 0 & 64,23 & 65,57 & 55,06 & 61,03 & 60,68 & 60,99 & 57,35 & 60,70 \\
\hline & 150 & 74,77 & 57,40 & 47,59 & 61,45 & 61,97 & 57,21 & 57,72 & 59,73 \\
\hline & 300 & 68,41 & 66,26 & 58,59 & 64,17 & 61,21 & 49,65 & 55,27 & 60,51 \\
\hline \multirow{3}{*}{50} & 0 & 75,81 & 82,46 & 74,23 & 76,58 & 74,83 & 64,54 & 65,75 & 73,45 \\
\hline & 150 & 63,89 & 65,30 & 58,28 & 69,95 & 67,23 & 58,85 & 57,07 & 62,94 \\
\hline & 300 & 66,16 & 64,07 & 69,12 & 69,67 & 66,87 & 58,22 & 60,05 & 64,88 \\
\hline \multirow{3}{*}{75} & 0 & 86,19 & 77,30 & 83,77 & 96,54 & 82,98 & 67,94 & 76,84 & 81,65 \\
\hline & 150 & 59,76 & 56,29 & 63,98 & 80,47 & 66,65 & 59,37 & 53,91 & 62,92 \\
\hline & 300 & 55,84 & 71,17 & 80,54 & 87,39 & 87,62 & 72,24 & 60,70 & 73,65 \\
\hline \multicolumn{10}{|c|}{ Efeitos Principais } \\
\hline 25 & & 69,14 & 63,07 & 53,74 & 62,22 & 61,29 & 55,95 & 56,78 & 60,31 \\
\hline 50 & & 68,62 & 70,61 & 67,21 & 72,07 & 69,64 & 60,54 & 60,95 & 67,09 \\
\hline \multirow[t]{4}{*}{75} & & 67,26 & 68,26 & 76,10 & 88,13 & 79,08 & 66,52 & 63,81 & 72,74 \\
\hline & 0 & 75,41 & 75,11 & 71,02 & 78,05 & 72,83 & 64,49 & 66,64 & 71,93 \\
\hline & 150 & 66,14 & 59,66 & 56,62 & 70,62 & 65,29 & 58,49 & 56,23 & 61,86 \\
\hline & 300 & 63,47 & 67,17 & 69,42 & 73,75 & 71,90 & 60,04 & 58,67 & 66,34 \\
\hline \multicolumn{10}{|c|}{ Dados Médios } \\
\hline \multirow{2}{*}{\multicolumn{2}{|c|}{$\begin{array}{l}\text { Média } \\
\text { CV }\end{array}$}} & 68,34 & 67,31 & 65,68 & 74,14 & 70,01 & 61,00 & 60,51 & 66,71 \\
\hline & & 18,25 & 19,09 & 21,31 & 19,81 & 19,80 & 22,36 & 22,75 & 21,20 \\
\hline \multicolumn{10}{|c|}{ Probabilidades Estatísticas } \\
\hline \multicolumn{10}{|c|}{ Concentrado } \\
\hline \multicolumn{2}{|c|}{ Linear $(\mathrm{L})$} & NS & NS & 0,0001 & 0,0001 & 0,0105 & NS & NS & 0,0235 \\
\hline \multicolumn{2}{|c|}{ Desvio (D) } & NS & NS & NS & NS & NS & NS & NS & NS \\
\hline \multicolumn{10}{|c|}{ Monensina } \\
\hline \multicolumn{2}{|c|}{ Linear (L) } & 0,0241 & NS & NS & NS & NS & NS & NS & NS \\
\hline \multicolumn{2}{|c|}{ Desvio (D) } & NS & 0,0372 & 0,0022 & NS & NS & NS & NS & NS \\
\hline \multicolumn{10}{|c|}{ Interação } \\
\hline Con & $\operatorname{mon}_{\mathrm{L}}$ & 0,0096 & NS & NS & NS & NS & NS & NS & NS \\
\hline Con & $\operatorname{mon}_{\mathrm{D}}$ & NS & NS & NS & NS & NS & NS & NS & NS \\
\hline Con & $\operatorname{mon}_{\mathrm{L}}$ & NS & NS & NS & NS & NS & NS & NS & NS \\
\hline Con & $\operatorname{mon}_{\mathrm{D}}$ & NS & NS & NS & NS & NS & NS & NS & NS \\
\hline
\end{tabular}


Tabela 11. Efeitos da proporção de concentrados (Con) e dose de monensina (Mon) sobre as concentrações de AGVs maiores $\left(\mathrm{C}_{2}+\mathrm{C}_{3}+\mathrm{C}_{4}\right)$ no líquido ruminal $(\mathrm{mM})$, em diferentes horas de amostragem, coeficientes de variação (CV) e probabilidades estatísticas no experimento com bovinos.

\begin{tabular}{|c|c|}
\hline Causas de variação & $\begin{array}{c}\text { Probabilidades } \\
\text { Estatísticas }\end{array}$ \\
\hline Tempo & 0,0001 \\
\hline Tempo X concentrado (Con) & \\
\hline Tempo X con $_{\text {Linear }}$ & 0,0001 \\
\hline Tempo $\mathrm{X}$ con Desvio & NS \\
\hline Tempo X monensina (Mon) & \\
\hline Tempo $X$ mon $_{\text {Linear }}$ & NS \\
\hline Tempo X mon Desvio & NS \\
\hline Tempo X concentrado X monensina & \\
\hline Tempo X con Linear $\mathrm{X}$ mon $_{\text {Linear }}$ & 0,0026 \\
\hline Tempo X con Linear $X$ mon $_{\text {Desvio }}$ & NS \\
\hline Tempo $X$ con $_{\text {Destio }} X$ mon $_{\text {Linear }}$ & NS \\
\hline Tempo $X$ con $_{\text {Destio }} X$ mon $_{\text {Desvio }}$ & NS \\
\hline
\end{tabular}




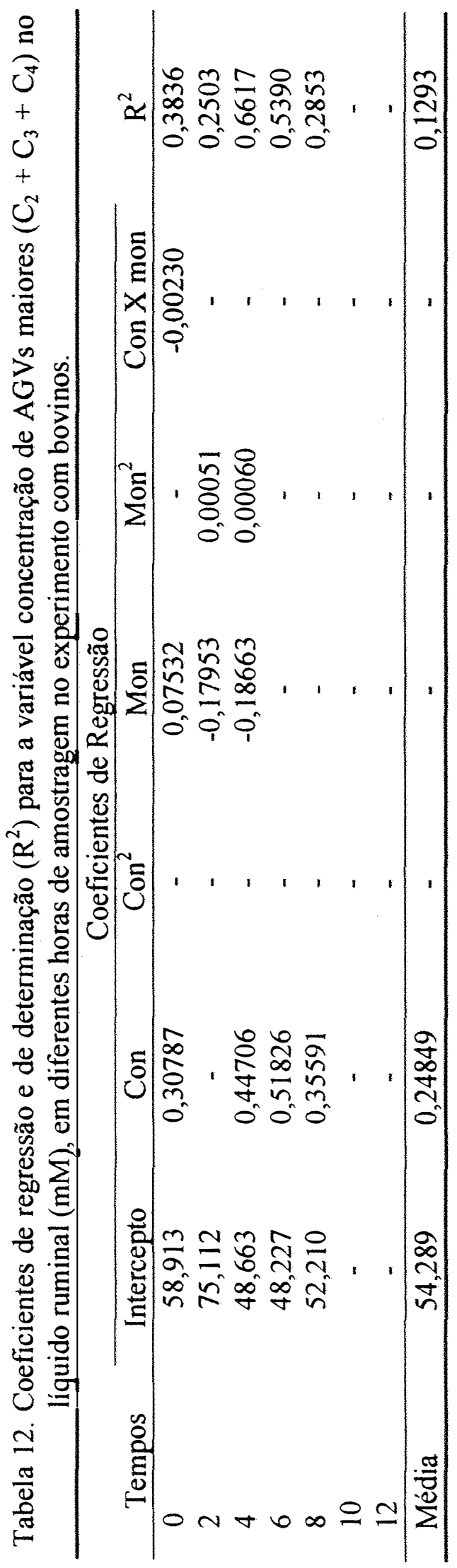


Tabela 13. Efeitos da proporção de concentrados (Con) e dose de monensina (Mon) sobre as porcentagens molares de acetato (\% molar) no líquido ruminal, em diferentes horas de amostragem, coeficientes de variação (CV) e probabilidades estatísticas no experimento com bovinos.

\begin{tabular}{|c|c|c|c|c|c|c|c|c|c|}
\hline \multicolumn{2}{|c|}{ Tratamentos } & \multicolumn{7}{|c|}{ Tempo (horas) } & \multirow[b]{2}{*}{ Média } \\
\hline Con & Mon & 0 & 2 & 4 & 6 & 8 & 10 & 12 & \\
\hline \multicolumn{10}{|c|}{ Interações } \\
\hline \multirow{3}{*}{25} & 0 & 80,83 & 79,86 & 80,30 & 79,72 & 80,08 & 80,27 & 80,99 & 80,29 \\
\hline & 150 & 76,81 & 78,07 & 78,59 & 76,56 & 76,40 & 77,22 & 78,04 & 77,39 \\
\hline & 300 & 77,67 & 76,33 & 75,83 & 75,17 & 75,55 & 76,84 & 77,52 & 76,42 \\
\hline \multirow{3}{*}{50} & 0 & 74,41 & 73,30 & 73,79 & 72,36 & 72,03 & 72,98 & 73,77 & 73,23 \\
\hline & 150 & 75,01 & 73,74 & 74,02 & 71,54 & 72,23 & 73,37 & 74,69 & 73,52 \\
\hline & 300 & 72,39 & 71,78 & 71,09 & 69,84 & 70,21 & 71,62 & 72,74 & 71,38 \\
\hline \multirow{3}{*}{75} & 0 & 65,54 & 66,31 & 66,32 & 64,63 & 64,76 & 65,87 & 65,77 & 65,60 \\
\hline & 150 & 73,45 & 72,65 & 71,03 & 69,04 & 69,80 & 71,08 & 72,73 & 71,40 \\
\hline & 300 & 59,17 & 57,60 & 55,57 & 54,68 & 54,57 & 65,32 & 58,63 & 56,65 \\
\hline \multicolumn{10}{|c|}{ Efeitos Principais } \\
\hline 25 & & 78,44 & 78,09 & 78,24 & 77,15 & 77,34 & 78,11 & 78,85 & 78,03 \\
\hline 50 & & 73,94 & 72,94 & 72,97 & 71,25 & 71,49 & 72,65 & 73,73 & 72,71 \\
\hline \multirow[t]{4}{*}{75} & & 66,05 & 65,52 & 64,31 & 62,79 & 63,04 & 64,42 & 65,71 & 64,55 \\
\hline & 0 & 73,59 & 73,16 & 73,47 & 72,24 & 72,29 & 73,04 & 73,51 & 73,04 \\
\hline & 150 & 75,09 & 74,82 & 74,55 & 72,38 & 72,81 & 73,89 & 75,15 & 74,10 \\
\hline & 300 & 69,75 & 68,57 & 67,48 & 66,56 & 66,77 & 68,26 & 69,63 & 68,15 \\
\hline \multicolumn{10}{|c|}{ Dados Médios } \\
\hline \multirow{2}{*}{\multicolumn{2}{|c|}{$\begin{array}{l}\text { Média } \\
\text { CV }\end{array}$}} & 72,81 & 72,18 & 71,84 & 70,39 & 70,63 & 71,73 & 72,76 & 71,76 \\
\hline & & 9,86 & 10,06 & 10,91 & 11,09 & 11,11 & 10,60 & 9,90 & 10,41 \\
\hline \multicolumn{10}{|c|}{ Probabilidades Estatísticas } \\
\hline \multicolumn{10}{|c|}{ Concentrado } \\
\hline \multicolumn{2}{|c|}{ Linear $(\mathrm{L})$} & 0,0001 & 0,0001 & 0,0001 & 0,0001 & 0,0001 & 0,0001 & 0,0001 & 0,0001 \\
\hline \multicolumn{2}{|c|}{ Desvio (D) } & NS & NS & NS & NS & NS & NS & NS & NS \\
\hline \multicolumn{10}{|c|}{ Monensina } \\
\hline \multicolumn{2}{|c|}{ Linear (L) } & NS & 0,0307 & 0,0055 & 0,0059 & 0,0071 & 0,0215 & 0,0386 & 0,0148 \\
\hline \multicolumn{2}{|c|}{ Desvio (D) } & NS & 0,0313 & 0,0227 & NS & NS & NS & 0,0286 & 0,0383 \\
\hline \multicolumn{10}{|c|}{ Interação } \\
\hline $\mathrm{Con}_{1}$ & $\operatorname{mon}_{\mathrm{L}}$ & NS & NS & NS & NS & NS & NS & NS & NS \\
\hline Con $_{1}$ & $\operatorname{mon}_{\mathrm{D}}$ & 0,0046 & 0,0189 & 0,0277 & 0,0156 & 0,0077 & 0,0117 & 0,0054 & 0,0092 \\
\hline $\mathrm{Con}_{\mathrm{I}}$ & $\operatorname{mon}_{\mathrm{L}}$ & NS & NS & NS & NS & NS & NS & NS & NS \\
\hline Con $_{r}$ & $\operatorname{mon}_{\mathrm{D}}$ & NS & NS & NS & NS & NS & NS & NS & NS \\
\hline
\end{tabular}


Tabela 13. Efeitos da proporção de concentrados (Con) e dose de monensina (Mon) sobre as porcentagens molares de acetato (\% molar) no líquido ruminal, em diferentes horas de amostragem, coeficientes de variação $(\mathrm{CV})$ e probabilidades estatísticas no experimento com bovinos.

\begin{tabular}{|c|c|}
\hline Causas de variação & $\begin{array}{c}\text { Probabilidades } \\
\text { Estatísticas }\end{array}$ \\
\hline Tempo & 0,0001 \\
\hline Tempo X concentrado (Con) & \\
\hline Tempo $X$ con $_{\text {Linear }}$ & 0,0166 \\
\hline Tempo X con Desvio & NS \\
\hline Tempo X monensina (Mon) & \\
\hline Tempo X mon Linear & 0,0076 \\
\hline Tempo X mon & NS \\
\hline Tempo $\mathrm{X}$ concentrado $\mathrm{X}$ monensina & \\
\hline Tempo X con cinear $\mathrm{X}$ mon Linear & NS \\
\hline Tempo X con $_{\text {Linear }} \mathrm{X}$ mon ${ }_{\text {Desvio }}$ & NS \\
\hline Tempo $X$ con $_{\text {Desvio }} X$ mon $_{\text {Linear }}$ & NS \\
\hline Tempo $X$ con $_{\text {Destio }} X$ mon Desvio & NS \\
\hline
\end{tabular}




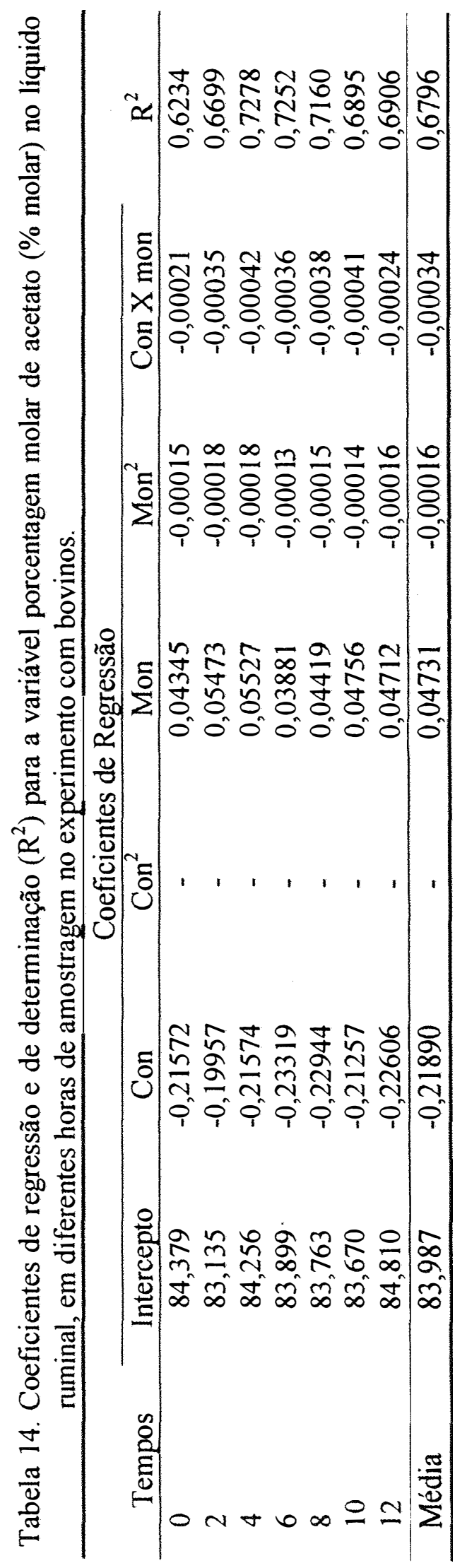



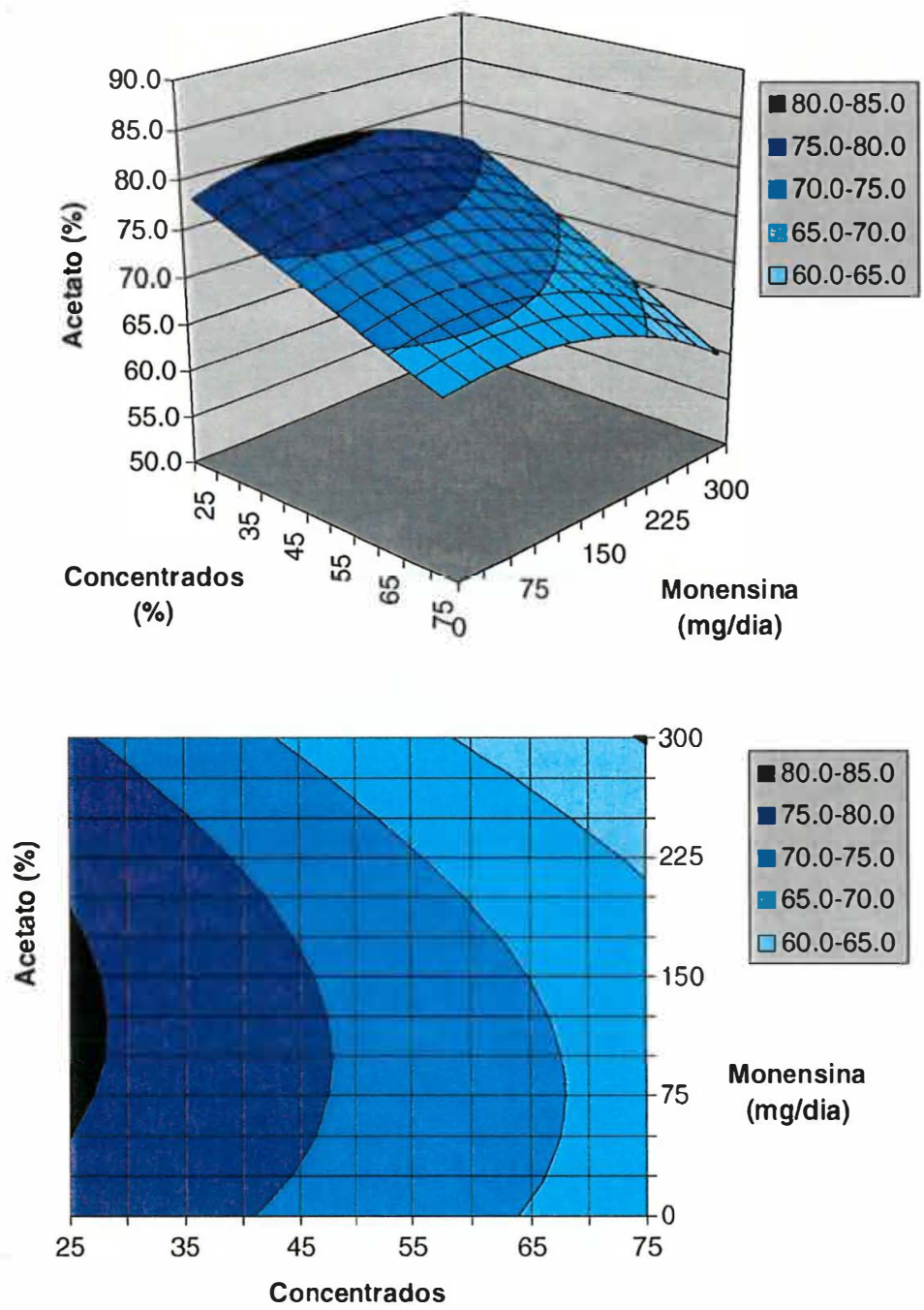

(\%)

Figura 03 - Efeitos da proporção de concentrados (\% da dieta) e dose de monensina (mg/animal/dia) sobre a porcentagem molar de acetato média (\% molar) no líquido ruminal, entre as diferentes horas de amostragem, obtidos no experimento com bovinos. 


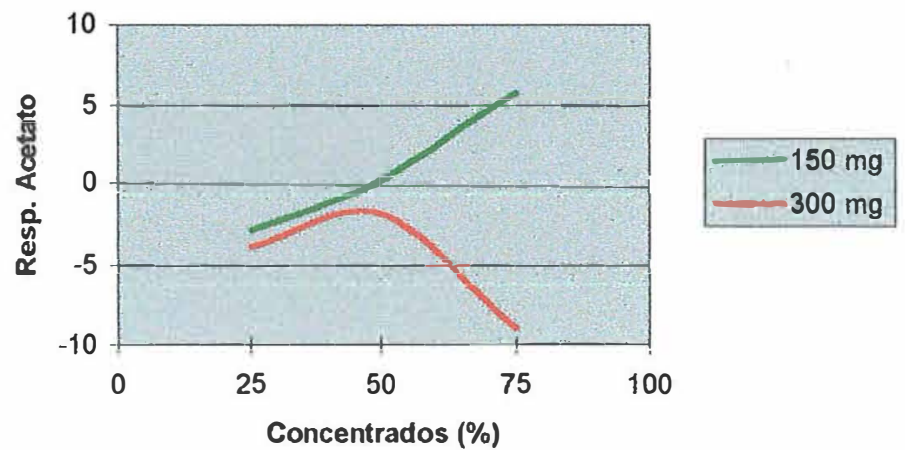

Figura 04 - Resposta da porcentagem molar de acetato média (unidades de \% molar) no líquido ruminal ao efeito da administração de monensina ( $\mathrm{mg} /$ animal/dia) em diferentes proporções de concentrados na dieta, obtidos no experimento com bovinos. 
Tabela 15. Efeitos da proporção de concentrados (Con) e dose de monensina (Mon) sobre as porcentagens molares de propionato (\% molar) no líquido ruminal, em diferentes horas de amostragem, coeficientes de variação (CV) e probabilidades estatísticas no experimento com bovinos.

\begin{tabular}{|c|c|c|c|c|c|c|c|c|c|}
\hline \multicolumn{2}{|c|}{ Tratamentos } & \multicolumn{7}{|c|}{ Tempo (horas) } & \multirow[b]{2}{*}{ Média } \\
\hline Con & Mon & 0 & 2 & 4 & 6 & 8 & 10 & 12 & \\
\hline \multicolumn{10}{|c|}{ Interaçōes } \\
\hline \multirow{3}{*}{25} & 0 & 13,87 & 13,99 & 13,54 & 13,90 & 13,84 & 13,93 & 13,70 & 13,83 \\
\hline & 150 & 17,65 & 15,92 & 15,45 & 17,08 & 17,43 & 16,78 & 16,44 & 16,68 \\
\hline & 300 & 16,95 & 17,26 & 17,51 & 18,05 & 17,88 & 17,04 & 16,71 & 17,34 \\
\hline \multirow{3}{*}{50} & 0 & 16,66 & 16,76 & 16,42 & 17,27 & 17,11 & 16,24 & 15,86 & 16,62 \\
\hline & 150 & 17,80 & 17,94 & 17,51 & 19,03 & 18,65 & 17,75 & 17,01 & 17,96 \\
\hline & 300 & 20,36 & 20,18 & 21,23 & 22,51 & 22,13 & 20,88 & 19,80 & 21,01 \\
\hline \multirow{3}{*}{75} & 0 & 24,95 & 24,47 & 24,88 & 26,32 & 25,76 & 24,75 & 24,59 & 25,10 \\
\hline & 150 & 18,32 & 18,70 & 20,83 & 22,77 & 21,68 & 20,11 & 18,80 & 20,17 \\
\hline & 300 & 34,99 & 35,94 & 38,47 & 40,21 & 40,26 & 38,26 & 35,42 & 37,65 \\
\hline \multicolumn{10}{|c|}{ Efeitos Principais } \\
\hline 25 & & 16,16 & 15,72 & 15,50 & 16,35 & 16,39 & 15,92 & 15,62 & 15,95 \\
\hline 50 & & 18,27 & 18,29 & 18,39 & 19,60 & 19,30 & 18,29 & 17,56 & 18,53 \\
\hline \multirow[t]{4}{*}{75} & & 26,09 & 26,37 & 28,06 & 29,76 & 29,23 & 27,70 & 26,27 & 27,64 \\
\hline & 0 & 18,49 & 18,41 & 18,28 & 19,16 & 18,90 & 18,30 & 18,05 & 18,51 \\
\hline & 150 & 17,92 & 17,52 & 17,94 & 19,63 & 19,26 & 18,21 & 17,42 & 18,27 \\
\hline & 300 & 24,10 & 24,46 & 25,74 & 26,92 & 26,76 & 25,39 & 23,97 & 25,33 \\
\hline \multicolumn{10}{|c|}{ Dados Médios } \\
\hline \multirow{2}{*}{\multicolumn{2}{|c|}{$\begin{array}{l}\text { Média } \\
\text { CV }\end{array}$}} & 20,17 & 20,13 & 20,65 & 21,90 & 21,64 & 20,64 & 19,81 & 20,71 \\
\hline & & 34,93 & 36,52 & 39,05 & 37,99 & 38,39 & 38,56 & 36,44 & 37,08 \\
\hline \multicolumn{10}{|c|}{ Probabilidades Estatísticas } \\
\hline \multicolumn{10}{|c|}{ Concentrado } \\
\hline \multicolumn{2}{|c|}{ Linear (L) } & 0,0002 & 0,0001 & 0,0001 & 0,0001 & 0,0001 & 0,0001 & 0,0001 & 0,0001 \\
\hline \multicolumn{2}{|c|}{ Desvio (D) } & NS & NS & NS & NS & NS & NS & NS & NS \\
\hline \multicolumn{10}{|c|}{ Monensina } \\
\hline \multicolumn{2}{|c|}{ Linear (L) } & 0,0140 & 0,0107 & 0,0017 & 0,0011 & 0,0011 & 0,0037 & 0,0079 & 0,0032 \\
\hline \multicolumn{2}{|c|}{ Desvio (D) } & NS & 0,0465 & 0,0306 & NS & NS & NS & 0,0494 & 0,0476 \\
\hline \multicolumn{10}{|c|}{ Interação } \\
\hline Con & $\operatorname{mon}_{\mathrm{L}}$ & NS & NS & NS & NS & 0,0469 & NS & NS & NS \\
\hline Con & $\operatorname{mon}_{D}$ & 0,0053 & 0,0173 & 0,0211 & 0,0130 & 0,0074 & 0,0113 & 0,0084 & 0,0095 \\
\hline Con & $\operatorname{mon}_{\mathrm{L}}$ & NS & NS & NS & NS & NS & NS & NS & NS \\
\hline Con & $\operatorname{mon}_{D}$ & NS & NS & NS & NS & NS & NS & NS & NS \\
\hline
\end{tabular}


Tabela 15. Efeitos da proporção de concentrados (Con) e dose de monensina (Mon) sobre as porcentagens molares de propionato (\% molar) no líquido ruminal, em diferentes horas de amostragem, coeficientes de variação $(\mathrm{CV})$ e probabilidades estatísticas no experimento com bovinos.

\begin{tabular}{|c|c|}
\hline Causas de variação & $\begin{array}{l}\text { Probabilidades } \\
\text { Estatísticas }\end{array}$ \\
\hline Tempo & 0,0001 \\
\hline Tempo X concentrado (Con) & \\
\hline Tempo X con Linear & 0,0001 \\
\hline Tempo X con Desvio & NS \\
\hline Tempo X monensina (Mon) & \\
\hline Tempo X mon Linear & 0,0046 \\
\hline Tempo X mon Desvio & NS \\
\hline Tempo X concentrado X monensina & \\
\hline Tempo X con Linear $\mathrm{X}$ mon $_{\text {Linear }}$ & NS \\
\hline Tempo $X$ con $_{\text {Linear }} \mathrm{X}$ mon & NS \\
\hline Tempo X con Desvio $\mathrm{X}$ mon $_{\text {Linear }}$ & NS \\
\hline Tempo X con Desvio $\mathrm{X}$ mon $_{\text {Desvio }}$ & NS \\
\hline
\end{tabular}




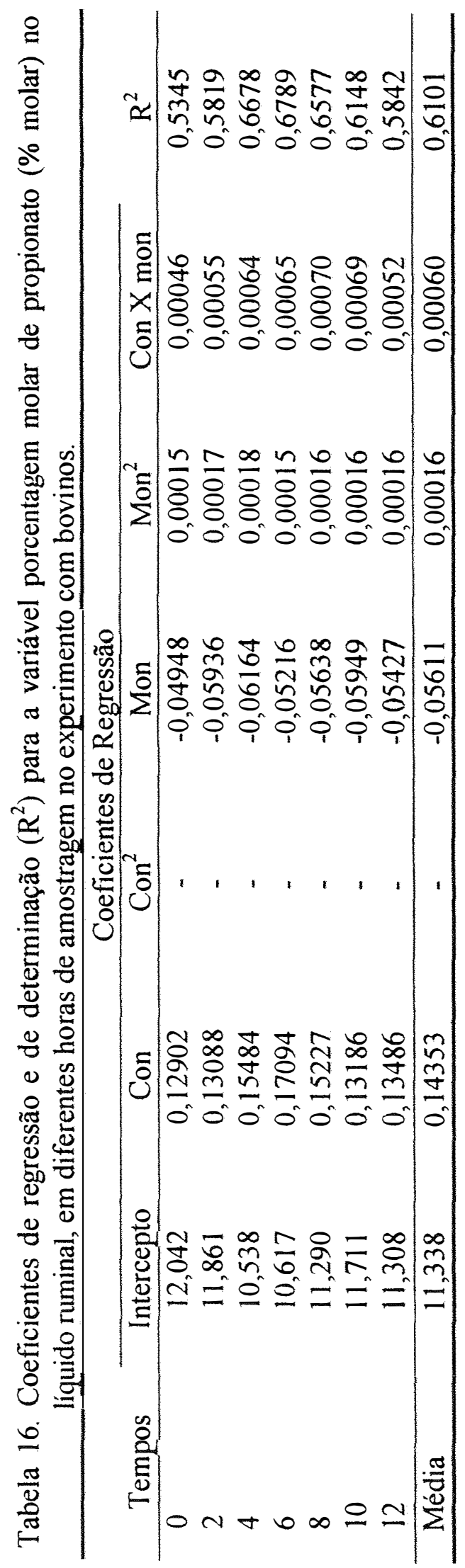



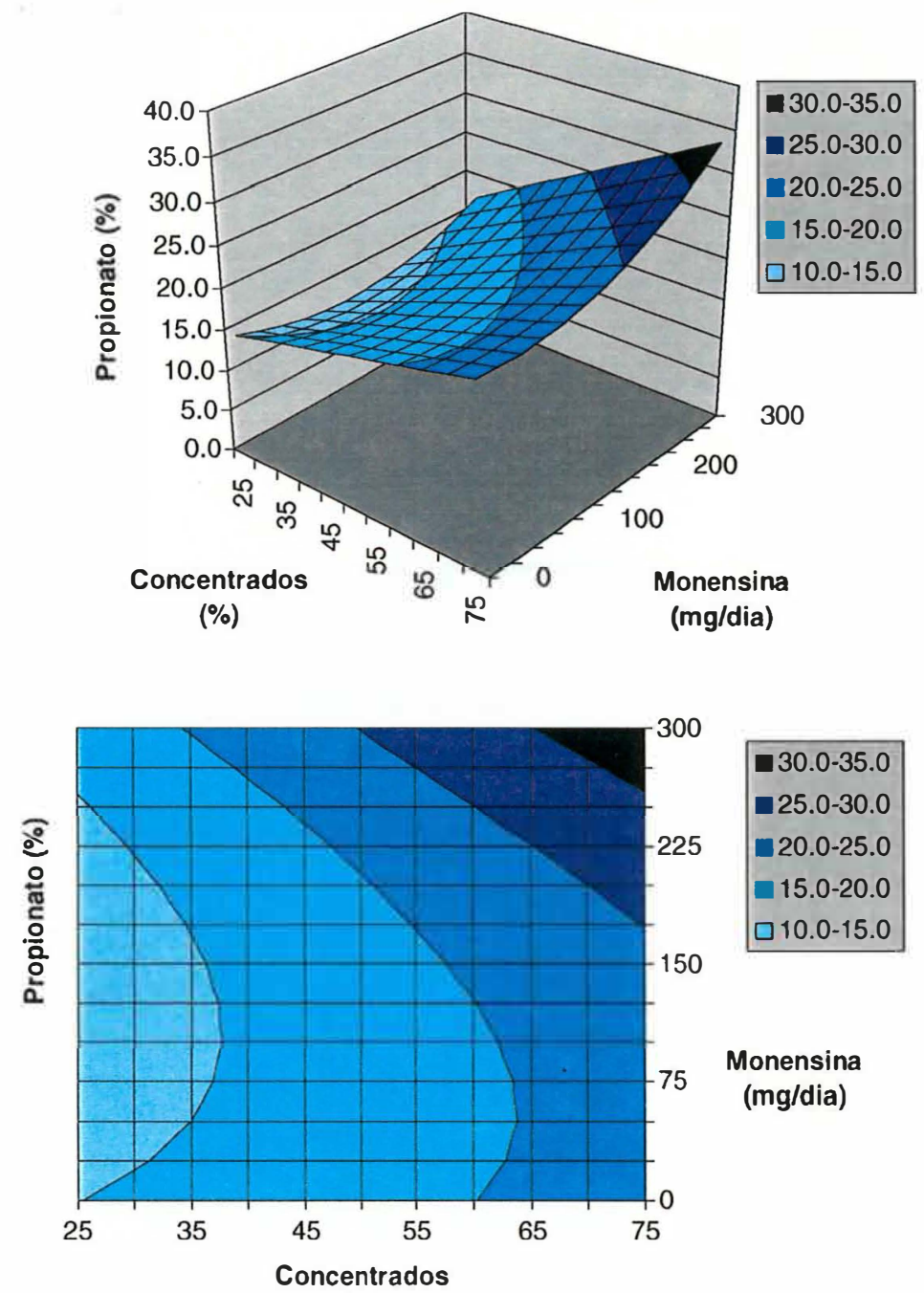

(\%)

Figura 05 - Efeitos da proporção de concentrados (\% da dieta) e dose de monensina (mg/animal/dia) sobre a porcentagem molar de propionato média (\% molar) no líquido ruminal, entre as diferentes horas de amostragem, obtidos no experimento com bovinos. 


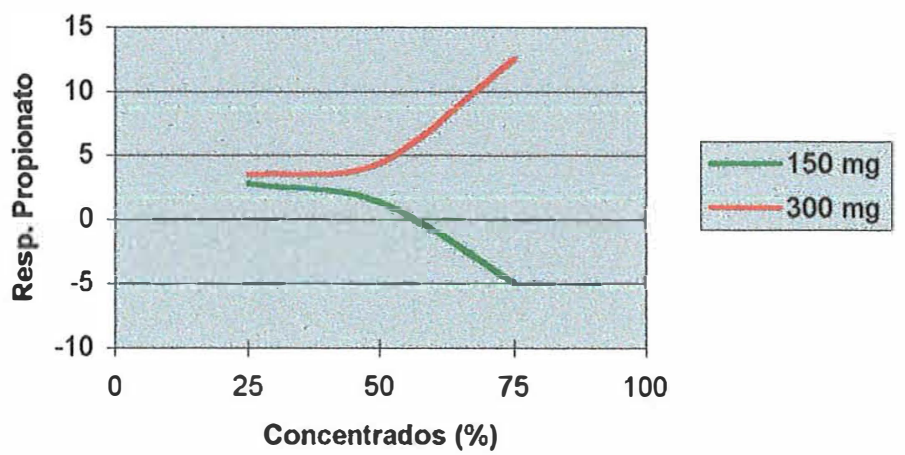

Figura 06 - Resposta da porcentagem molar de propionato média (unidades de $\%$ molar) no líquido ruminal ao efeito da administração de monensina (mg/animal/dia) em diferentes proporções de concentrados na dieta, obtida no experimento com bovinos. 
Tabela 17. Efeitos da proporção de concentrados (Con) e dose de monensina (Mon) sobre as porcentagens molares de butirato (\% molar) no líquido ruminal, em diferentes horas de amostragem, coeficientes de variação (CV) e probabilidades estatísticas no experimento com bovinos.

\begin{tabular}{|c|c|c|c|c|c|c|c|c|c|}
\hline \multicolumn{2}{|c|}{ Tratamentos } & \multicolumn{7}{|c|}{ Tempo (horas) } & \multirow[b]{2}{*}{ Média } \\
\hline Con & Mon & 0 & 2 & 4 & 6 & 8 & 10 & 12 & \\
\hline \multicolumn{10}{|c|}{ Interações } \\
\hline \multirow{3}{*}{25} & 0 & 5,30 & 6,15 & 6,16 & 6,38 & 6,07 & 5,80 & 5,31 & 5,88 \\
\hline & 150 & 5,54 & 6,01 & 5,96 & 6,36 & 6,17 & 6,00 & 5,52 & 5,94 \\
\hline & 300 & 5,38 & 6,41 & 6,66 & 6,78 & 6,57 & 6,11 & 5,77 & 6,24 \\
\hline \multirow{3}{*}{50} & 0 & 8,93 & 9,94 & 9,79 & 10,36 & 10,86 & 10,78 & 10,37 & 10,15 \\
\hline & 150 & 7,18 & 8,32 & 8,46 & 9,43 & 9,11 & 8,88 & 8,30 & 8,53 \\
\hline & 300 & 7,25 & 8,04 & 7,68 & 7,66 & 7,66 & 7,50 & 7,47 & 7,61 \\
\hline \multirow{3}{*}{75} & 0 & 9,51 & 9,22 & 8,80 & 9,05 & 9,48 & 9,38 & 9,64 & 9,30 \\
\hline & 150 & 8,23 & 8,65 & 8,14 & 8,19 & 8,51 & 8,81 & 8,47 & 8,43 \\
\hline & 300 & 5,84 & 6,47 & 5,96 & 5,11 & 5,17 & 5,42 & 5,95 & 5,70 \\
\hline \multicolumn{10}{|c|}{ Efeitos Principais } \\
\hline 25 & & 5,41 & 6,19 & 6,26 & 6,51 & 6,27 & 5,97 & 5,54 & 6,02 \\
\hline 50 & & 7,79 & 8,77 & 8,64 & 9,15 & 9,21 & 9,06 & 8,71 & 8,76 \\
\hline \multirow[t]{4}{*}{75} & & 7,86 & 8,11 & 7,63 & 7,45 & 7,72 & 7,87 & 8,02 & 7,81 \\
\hline & 0 & 7,91 & 8,44 & 8,25 & 8,60 & 8,80 & 8,65 & 8,44 & 8,44 \\
\hline & 150 & 6,99 & 7,66 & 7,52 & 7,99 & 7,93 & 7,90 & 7,43 & 7,63 \\
\hline & 300 & 6,16 & 6,97 & 6,77 & 6,52 & 6,47 & 6,34 & 6,40 & 6,52 \\
\hline \multicolumn{10}{|c|}{ Dados Médios } \\
\hline \multirow{2}{*}{\multicolumn{2}{|c|}{$\begin{array}{l}\text { Média } \\
\text { CV }\end{array}$}} & 7,02 & 7,69 & 7,51 & 7,70 & 7,73 & 7,63 & $7 ; 42$ & 7,53 \\
\hline & & 28,85 & 22,39 & 21,19 & 25,32 & 28,05 & 29,86 & 30,92 & 26,58 \\
\hline \multicolumn{10}{|c|}{ Probabilidades Estatísticas } \\
\hline \multicolumn{10}{|c|}{ Concentrado } \\
\hline \multicolumn{2}{|c|}{ Linear $(\mathrm{L})$} & 0,0034 & 0,0028 & 0,0118 & NS & NS & 0,0310 & 0,0085 & 0,0118 \\
\hline Desv & (D) & NS & 0,0034 & 0,0009 & 0,0010 & 0,0023 & 0,0073 & 0,0159 & 0,0038 \\
\hline \multicolumn{10}{|c|}{ Monensina } \\
\hline \multicolumn{2}{|c|}{ Linear (L) } & 0,0254 & 0,0159 & 0,0074 & 0,0042 & 0,0043 & 0,0109 & 0,0253 & 0,0075 \\
\hline Desy & (D) & NS & NS & NS & NS & NS & NS & NS & NS \\
\hline \multicolumn{10}{|c|}{ Interação } \\
\hline \multirow{2}{*}{\multicolumn{2}{|c|}{$\begin{array}{l}\mathrm{Con}_{\mathrm{L}} \mathrm{Xmon}_{\mathrm{L}} \\
\mathrm{Con}_{\mathrm{L}} \mathrm{Xmon}_{\mathrm{D}}\end{array}$}} & 0,0471 & 0,0374 & 0,0124 & 0,0120 & 0,0131 & 0,0451 & NS & 0,0208 \\
\hline & & NS & NS & NS & NS & NS & NS & NS & NS \\
\hline \multirow{2}{*}{\multicolumn{2}{|c|}{$\begin{array}{l}\mathrm{Con}_{\mathrm{D}} \mathrm{Xmon}_{\mathrm{L}} \\
\text { Con } \mathrm{Xmon}_{\mathrm{P}}\end{array}$}} & NS & NS & NS & NS & NS & NS & NS & NS \\
\hline & & NS & NS & NS & NS & NS & NS & NS & NS \\
\hline
\end{tabular}


Tabela 17. Efeitos da proporção de concentrados (Con) e dose de monensina (Mon) sobre as porcentagens molares de butirato (\% molar) no líquido ruminal, em diferentes horas de amostragem, coeficientes de variação $(\mathrm{CV})$ e probabilidades estatísticas no experimento com bovinos.

\begin{tabular}{|c|c|}
\hline Causas de variação & $\begin{array}{c}\text { Probabilidades } \\
\text { Estatísticas }\end{array}$ \\
\hline Tempo & 0,0007 \\
\hline Tempo X concentrado (Con) & \\
\hline Tempo X con $_{\text {Linear }}$ & 0,0023 \\
\hline Tempo X con Desvio & 0,0393 \\
\hline Tempo X monensina (Mon) & \\
\hline Tempo X mon Linear & NS \\
\hline Tempo X mon Desvio & NS \\
\hline Tempo X concentrado X monensina & \\
\hline Tempo $X \operatorname{con}_{\text {Linear }} \mathrm{X}$ mon $_{\text {Linear }}$ & NS \\
\hline Tempo $X$ con $_{\text {Linear }} \mathrm{X}$ mon $_{\text {Desvio }}$ & NS \\
\hline Tempo $X$ con $_{\text {Desvio }} X$ mon $_{\text {Linear }}$ & NS \\
\hline Tempo $X$ con $_{\text {Desvio }} X$ mon Desio & NS \\
\hline
\end{tabular}




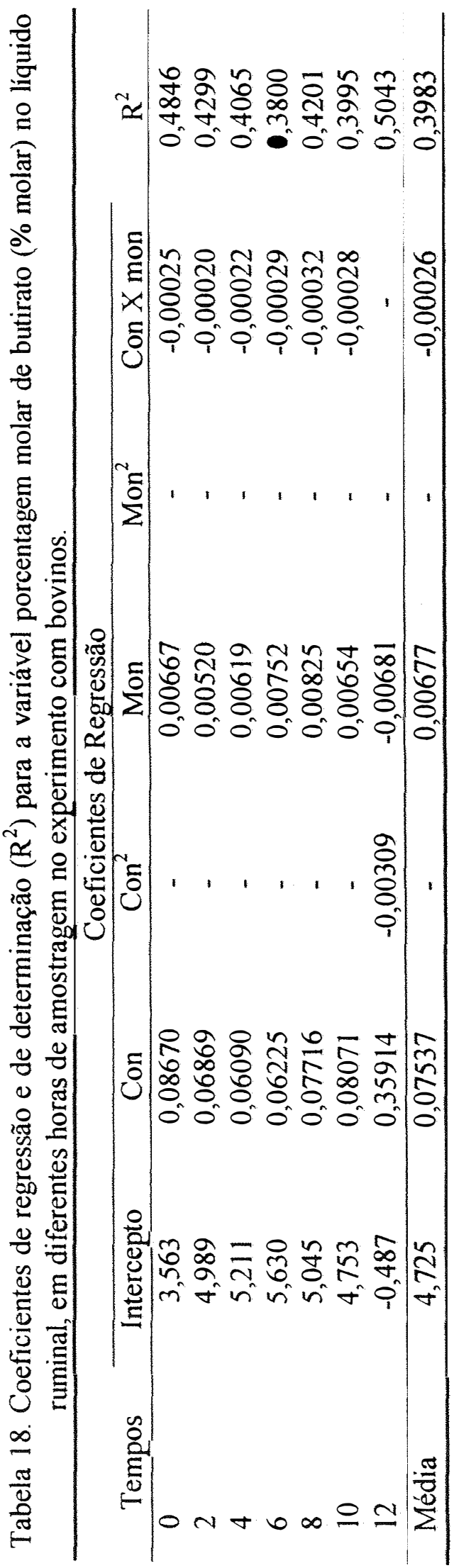



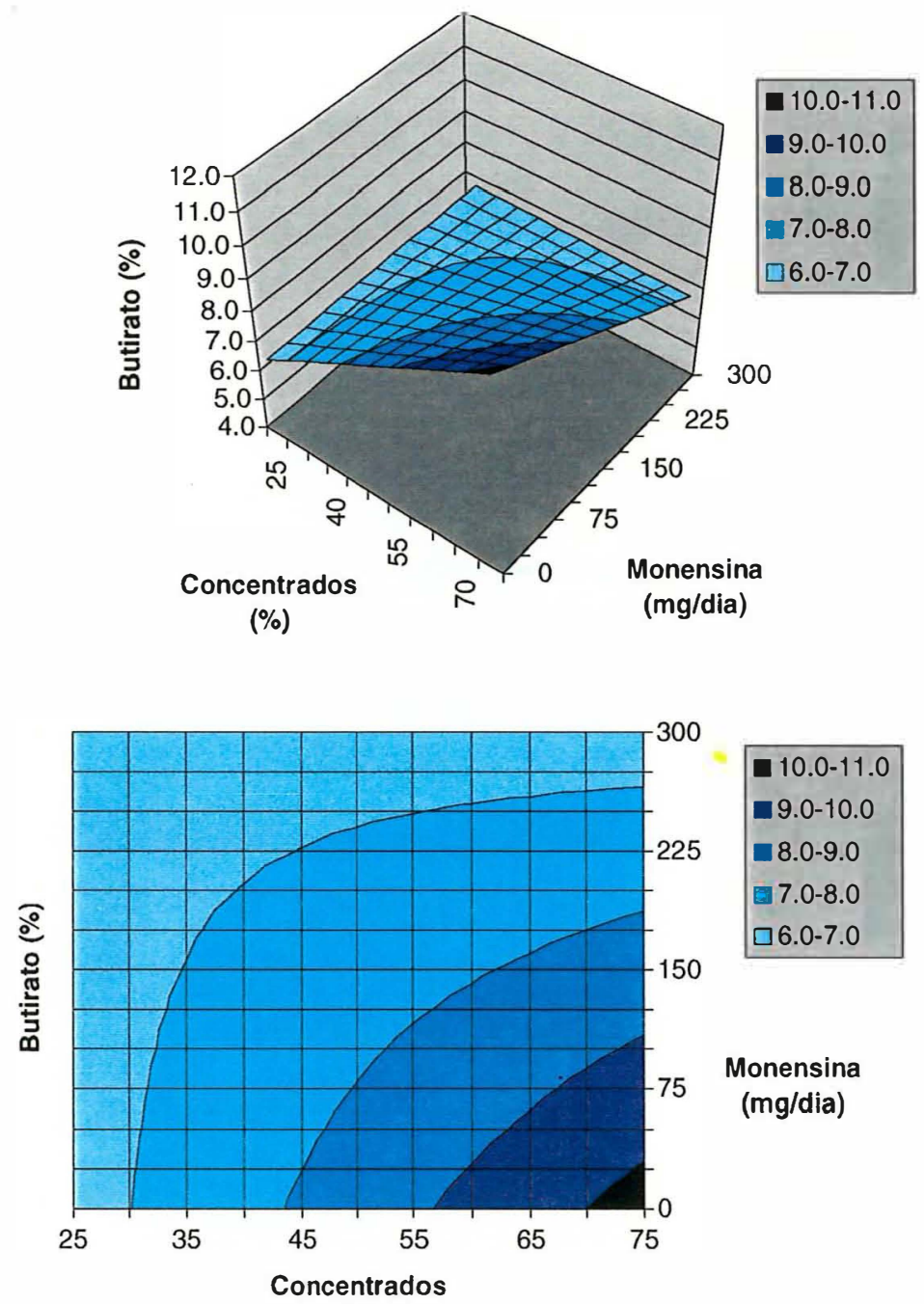

(\%)

Figura 07 - Efeitos da proporção de concentrados (\% da dieta) e dose de monensina ( $\mathrm{mg} / \mathrm{animal} / \mathrm{dia}$ ) sobre a porcentagem molar de butirato média (\% molar) no líquido ruminal, entre as diferentes horas de amostragem, obtidos no experimento com bovinos. 


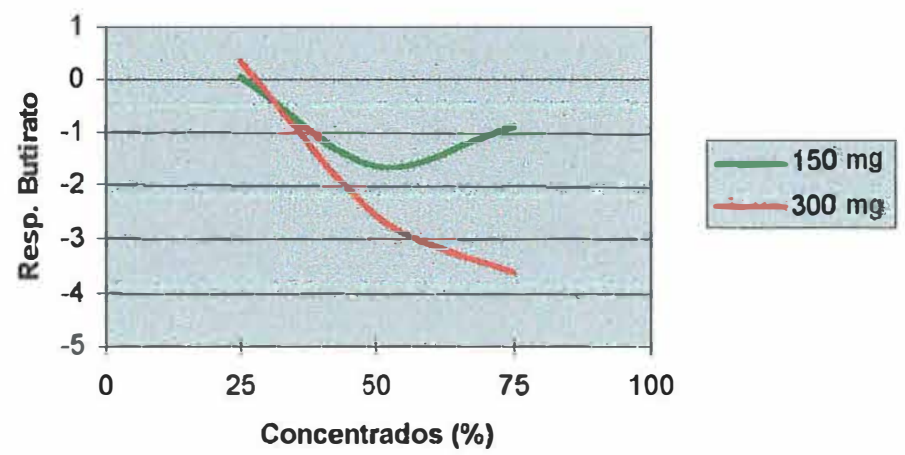

Figura 08 - Resposta da porcentagem molar de butirato média (unidades de \% molar) no líquido ruminal ao efeito da administração de monensina (mg/animal/dia) em diferentes proporções de concentrados na dieta, obtida no experimento com bovinos. 
Tabela 19. Efeitos da proporção de concentrados (Con) e dose de monensina (Mon) sobre as relações acetato:propionato (com base na \% molar) no líquido ruminal, em diferentes horas de amostragem, coefícientes de variação (CV) e probabilidades estatísticas no experimento com bovinos.

\begin{tabular}{|c|c|c|c|c|c|c|c|c|c|}
\hline \multicolumn{2}{|c|}{ Tratamentos } & \multicolumn{7}{|c|}{ Tempo (horas) } & \multirow[b]{2}{*}{ Média } \\
\hline Con & Mon & 0 & 2 & 4 & 6 & 8 & 10 & 12 & \\
\hline \multicolumn{10}{|c|}{ Interações } \\
\hline \multirow{3}{*}{25} & 0 & 5,84 & 5,72 & 5,94 & 5,77 & 5,80 & 5,81 & 5,94 & 5,83 \\
\hline & 150 & 4,37 & 4,93 & 5,12 & 4,50 & 4,81 & 4,65 & 4,76 & 4,68 \\
\hline & 300 & 4,61 & 4,43 & 4,34 & 4,18 & 4,24 & 4,52 & 4,64 & 4,42 \\
\hline \multirow{3}{*}{50} & 0 & 4,48 & 4,39 & 4,51 & 4,20 & 4,23 & 4,51 & 4,66 & 4,43 \\
\hline & 150 & 4,22 & 4,11 & 4,23 & 3,78 & 3,90 & 4,14 & 4,40 & 4,11 \\
\hline & 300 & 3,60 & 3,60 & 3,35 & 3,10 & 3,17 & 3,44 & 3,70 & 3,42 \\
\hline \multirow{3}{*}{75} & 0 & 2,76 & 2,84 & 2,79 & 2,62 & 2,67 & 2,86 & 2,82 & 2,77 \\
\hline & 150 & 4,13 & 3,95 & 3,48 & 3,09 & 3,30 & 3,69 & 4,03 & 3,67 \\
\hline & 300 & 1,86 & 1,77 & 1,56 & 1,44 & 1,44 & 1,57 & 1,76 & 1,63 \\
\hline \multicolumn{10}{|c|}{ Efeitos Principais } \\
\hline 25 & & 4,94 & 5,03 & 5,13 & 4,82 & 4,82 & 4,99 & 5,11 & 4,98 \\
\hline 50 & & 4,10 & 4,03 & 4,03 & 3,69 & 3,77 & 4,03 & 4,25 & 3,99 \\
\hline \multirow[t]{4}{*}{75} & & 2,92 & 2,85 & 2,61 & 2,38 & 2,47 & 2,71 & 2,87 & 2,69 \\
\hline & 0 & 4,36 & 4,32 & 4,42 & 4,20 & 4,23 & 4,39 & 4,47 & 4,34 \\
\hline & 150 & 4,24 & 4,33 & 4,28 & 3,79 & 3,87 & 4,16 & 4,40 & 4,15 \\
\hline & 300 & 3,36 & 3,26 & 3,08 & 2,91 & 2,95 & 3,17 & 3,37 & 3,16 \\
\hline \multicolumn{10}{|c|}{ Dados Médios } \\
\hline \multirow{2}{*}{\multicolumn{2}{|c|}{$\begin{array}{l}\text { Média } \\
\mathrm{CV}\end{array}$}} & 3,99 & 3,97 & 3,93 & 3,63 & 3,68 & 3,91 & 4,08 & 3,88 \\
\hline & & 30,60 & 30,26 & 33,44 & 34,84 & 34,13 & 32,76 & 30,96 & 32,10 \\
\hline \multicolumn{10}{|c|}{ Probabilidades Estatísticas } \\
\hline \multicolumn{10}{|c|}{ Concentrado } \\
\hline \multicolumn{2}{|c|}{ Linear (L) } & 0,0001 & 0,0001 & 0,0001 & 0,0001 & 0,0001 & 0,0001 & 0,0001 & 0,0001 \\
\hline Des & (D) & NS & NS & NS & NS & NS & NS & NS & NS \\
\hline \multicolumn{10}{|c|}{ Monensina } \\
\hline \multicolumn{2}{|c|}{ Linear (L) } & 0,0057 & 0,0016 & 0,0001 & 0,0001 & 0,0001 & 0,0011 & 0,0017 & 0,0003 \\
\hline Des & (D) & NS & 0,0382 & 0,0206 & NS & NS & NS & NS & NS \\
\hline \multicolumn{10}{|c|}{ Interação } \\
\hline Con & $\operatorname{mon}_{\mathrm{L}}$ & NS & NS & NS & NS & NS & NS & NS & NS \\
\hline Con & $\operatorname{mon}_{\mathrm{D}}$ & 0,0010 & 0,0078 & 0,0179 & 0,0057 & 0,0020 & 0,0079 & 0,0022 & 0,0026 \\
\hline Con & $\operatorname{mon}_{\mathrm{L}}$ & NS & NS & NS & NS & NS & NS & NS & NS \\
\hline Con & mon $_{\mathrm{D}}$ & NS & NS & NS & NS & NS & NS & NS & NS \\
\hline
\end{tabular}


Tabela 19. Efeitos da proporção de concentrados (Con) e dose de monensina (Mon) sobre as relações acetato:propionato (com base na \% molar) no líquido ruminal, em diferentes horas de amostragem, coeficientes de variação $(\mathrm{CV})$ e probabilidades estatísticas no experimento com bovinos.

\begin{tabular}{|c|c|}
\hline Causas de variação & $\begin{array}{c}\text { Probabilidades } \\
\text { Estatísticas }\end{array}$ \\
\hline Tempo & 0,0001 \\
\hline \multicolumn{2}{|l|}{ Tempo X concentrado (Con) } \\
\hline Tempo $X$ con $_{\text {Linear }}$ & 0,0401 \\
\hline Tempo X con Desvio & NS \\
\hline \multicolumn{2}{|l|}{ Tempo X monensina (Mon) } \\
\hline Tempo $\mathrm{X}$ mon $_{\text {Linear }}$ & NS \\
\hline Tempo X mon Destio & NS \\
\hline \multicolumn{2}{|l|}{ Tempo X concentrado X monensina } \\
\hline Tempo $X$ con $_{\text {Linear }} X$ mon $_{\text {Linear }}$ & NS \\
\hline Tempo X con Linear $\mathrm{X}$ mon Desvio & 0,0021 \\
\hline Tempo $X$ con $_{\text {Desvio }} \mathrm{X}$ mon $_{\text {Linear }}$ & NS \\
\hline Tempo $X$ con $_{\text {Desvio }} \mathrm{X}$ mon ${ }_{\text {Desvio }}$ & NS \\
\hline
\end{tabular}




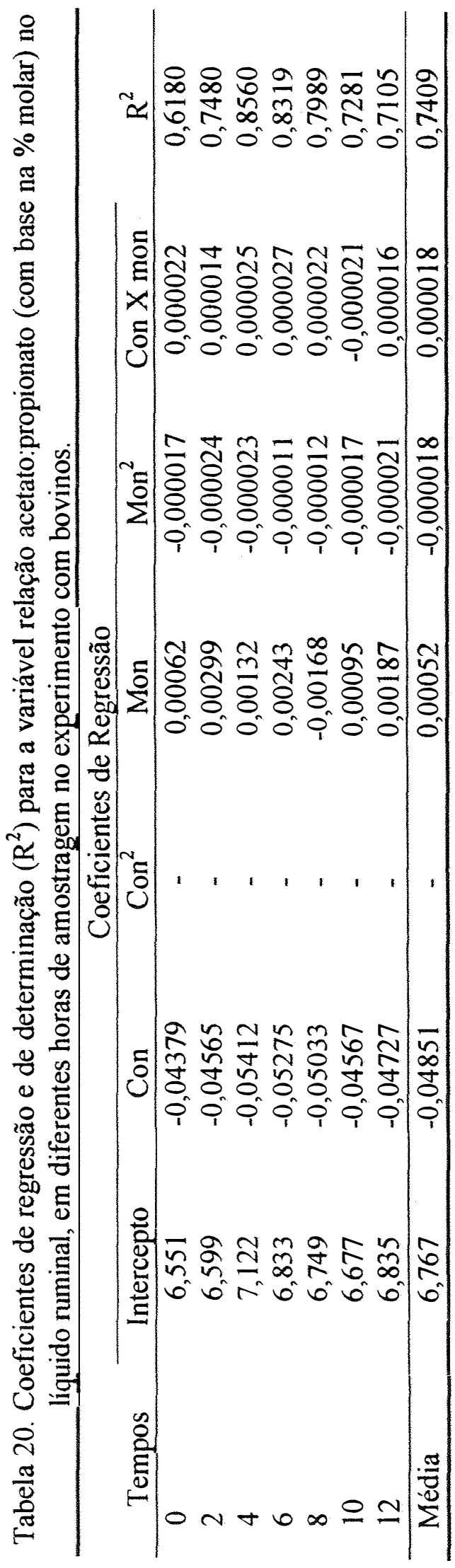



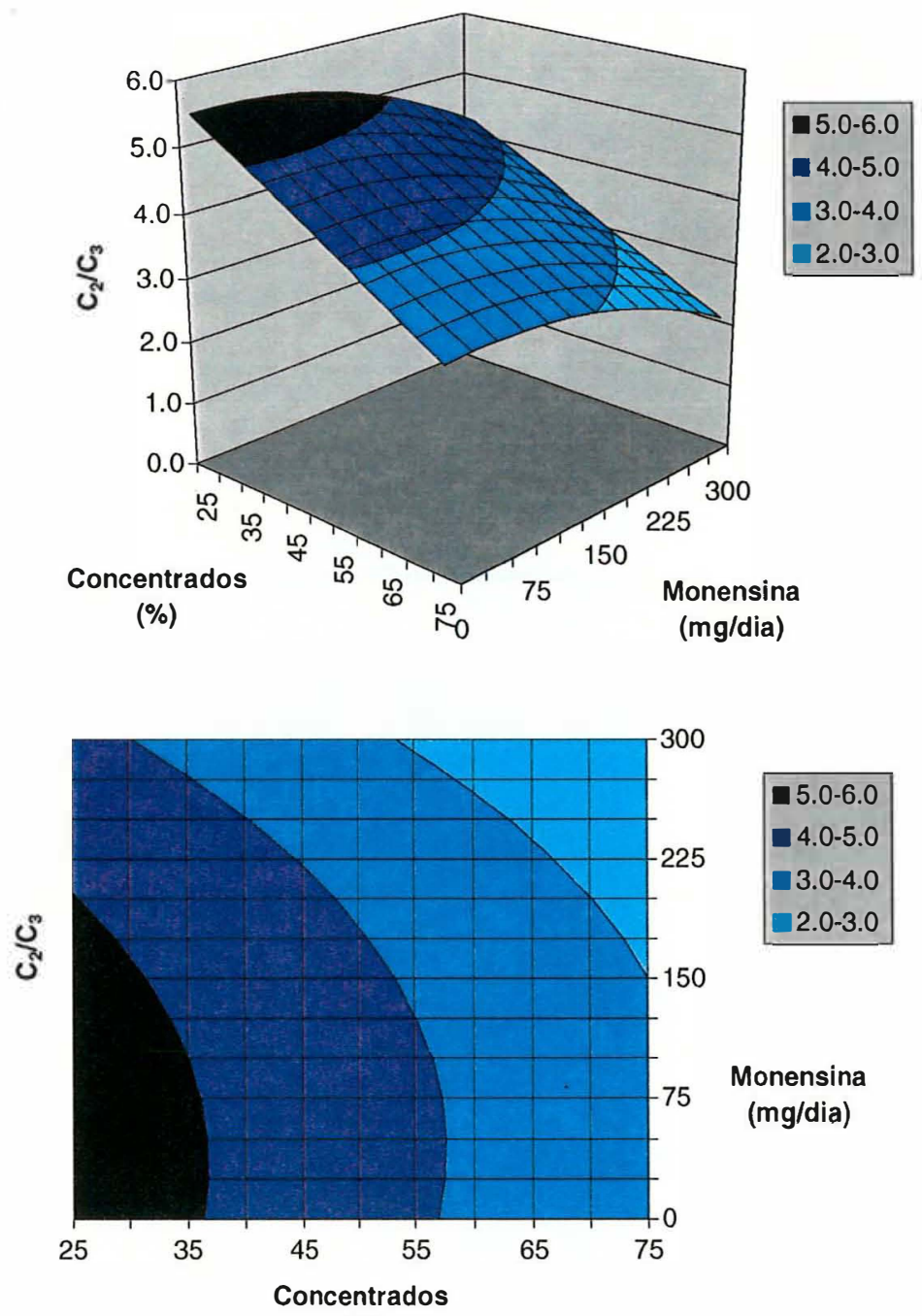

(\%)

Figura 09 - Efeitos da proporção de concentrados (\% da dieta) e dose de monensina (mg/animal/dia) sobre a relação acetato:propionato média (com base na \% molar) no líquido ruminal, entre as diferentes horas de amostragem, obtidos no experimento com bovinos. 


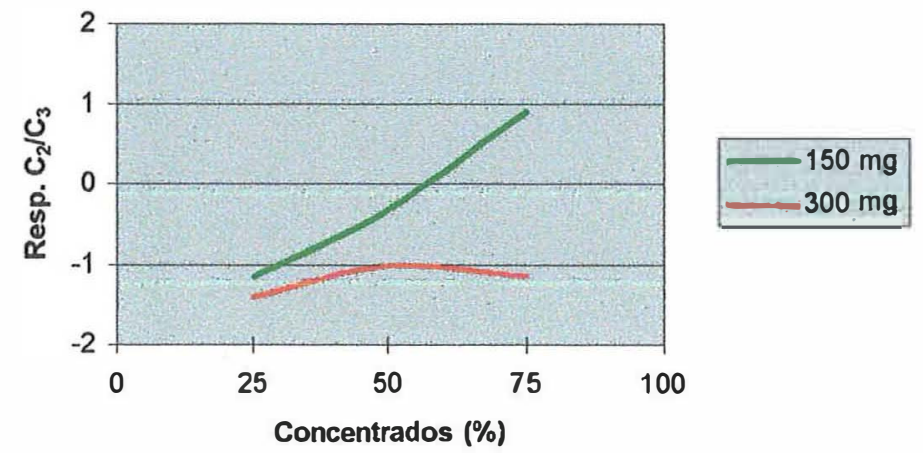

Figura 10 - Resposta da relação acetato:propionato média (unidades de relação acetato:propionato) no líquido ruminal ao efeito da administração de monensina (mg/animal/dia) em diferentes proporções de concentrados na dieta, obtida no experimento com bovinos. 


\subsection{Concentração de nitrogênio amoniacal no líquido ruminal}

A Tabela 21 traz as concentrações de nitrogênio amoniacal contidas no líquido ruminal obtidas no experimento com bovinos. Os valores ficaram em torno de $7,5 \mathrm{mg} / \mathrm{dl}$, em média, considerando todo o periodo diário de amostragem, o qual foi compreendido entre momentos antes da refeição até 12 horas após. O valor médio, tomado para todos os tratamentos durante a $6^{\text {a }}$ hora pós-alimentação, foi tão baixo quanto $0,7 \mathrm{mg} / \mathrm{dl}$ e tão alto quanto $18,3 \mathrm{mg} / \mathrm{dl}$, quando tomado com 2 horas após alimentação. O efeito de tempo para a concentração de amônia apresentou-se significativo $(\mathrm{P}=0,0001)$, sendo esta extrema variabilidade comum em ruminantes alimentados de forma intermitente (Mehres et al., 1977), sendo que outros fatores identificados na literatura podem ainda influenciar este parâmetro, tal como local de amostragem no rúmen, período de estocagem da amostra, conservante ácido utilizado, método de determinação e tipo da dieta (Wohlt et al., 1976).

Os valores médios encontrados apresentaram-se próximos dos valores de nitrogênio amoniacal recomendados por Satter \& Slyter (1974), Preston \& Leng (1987) e Pisulewski et al. (1981), correspondentes a 5,0mg/dl, 8,0mg/dl e 9,6mg/dl, respectivamente, para o máximo crescimento microbiano, mas bem abaixo dos $24 \mathrm{mg} / \mathrm{dl}$ recomendados por Mehres et al. (1977) para máximo desaparecimento do substrato, embora estes últimos tenham proposto não ser necessário manter constantemente altas concentrações de amônia no líquido ruminal.

Os tratamentos utilizados neste experimento interagiram com o fator tempo de amostragem e, ao ser realizada a análise estatística em cada tempo, observouse diferentes respostas para cada hora amostrada. Interações entre proporção de concentrados e dose de monensina ocorreram às 0 e 4 horas, mas não às $2,6,8,10$ e 12 horas. Em média, observou-se resposta curvilinear para a proporção de concentrados, com maiores níveis de nitrogênio amoniacal em dietas mistas, sendo o aumento de 1,3 $\mathrm{mg} / \mathrm{dl}(15,8 \%)$ para a dieta com $50 \%$ de concentrados e diminuição de $2,4 \mathrm{mg} / \mathrm{dl}$ 
$(30,7 \%)$ para a dieta com $75 \%$ de concentrados em relação à dieta com $25 \%$. Para a dose de monensina, a resposta foi do tipo linear, com diminuição das concentrações de nitrogênio amoniacal ao aumentar a dose do produto em $0,5 \mathrm{mg} / \mathrm{dl}(5,8 \%)$ para a dose $150 \mathrm{mg}$ e $2,4 \mathrm{mg} / \mathrm{dl}(27,8 \%)$ para a dose $300 \mathrm{mg}$, em média, em relação ao grupo controle.

As concentrações de nitrogênio amoniacal no líquido ruminal parecem ser resultado de um balanço entre sua utilização pelos microorganismos ruminais (líquido entre degradação e síntese da proteína), saída do rúmen através de absorção pela parede ruminal, efeito que é dependente do $\mathrm{pH}$, ou fluxo para o duodeno junto com a digesta (Chalupa, 1977). A grande quantidade de substratos prontamente disponiveis para a fermentação nas dietas predominantemente concentradas, com conseqüente produção de proteína microbiana, parece ter incrementado o desaparecimento do nitrogênio amoniacal, embora o pH mais baixo e o fluxo de líquidos mais lento favorecessem seu acúmulo no líquido ruminal nessas dietas. Isto concorda com a afirmação de Nocek \& Russell (1988) de que o balanço entre a disponibilidade de nitrogênio e carboidratos é o fator mais importante para reduzir as perdas.

Os resultados obtidos com a utilização de monensina concordam com os obtidos por Van Nevel \& Demeyer (1977), Poos et al. (1979), Whetstone et al. (1981), Rodriguez et al. (1986), Russell et al. (1988), Chen \& Russell (1991), Yang \& Russell (1993), Haimoud et al. (1995), Lana \& Russell (1997), Salles (1997) e Suber \& Bowman (1998), ao utilizarem a monensina, Bogaert et al. (1991) e Francisco Jr. (1994), ao utilizarem a lasalocida, e Starnes et al. (1984), ao utilizarem a lasalocida ou monensina, os quais demonstraram diminuição das concentrações ruminais de nitrogênio amoniacal com o uso de ionóforos, provavelmente por inibir a deaminação e proteólise ruminal (Van Nevel \& Demeyer, 1977; Whetstone et al., 1981), aumentar o escape da proteína da dieta (Poos et al., 1979; Faulkner et al., 1985) ou, ainda, aumentar o crescimento microbiano (Chalupa, 1977). No presente trabalho, esse efeito não pode ser explicado pela inibição da proteólise ruminal, já que a monensina aumentou a digestibilidade in vitro do farelo de soja com inóculo obtido 3 horas após administração da alimentação 
com monensina, assim como aumentou também o parâmetro $a$ da equação de Ørskov \& McDonald (1979), indicando aumentar a degradação ruminal da proteína, pelo menos quando incubada por curtos períodos de tempo e em altas concentrações do produto no líquido ruminal. Então, tal efeito poderia ser explicado pela diminuição à deaminação ou aumento do crescimento microbiano, sendo esta última explicação bastante compatível com o aumento da degradabilidade efetiva de grãos de milho obtido com a administração de monensina à dieta, como observado no presente experimento e que será demonstrado mais adiante.

A interação entre proporção de concentrados e dosagem de monensina observada para a $4^{\text {a }}$ hora após a alimentação (Figura 11) indica ser bem maior a resposta da monensina em diminuir as concentrações ruminais de nitrogênio amoniacal em dietas predominantemente concentradas $(-3,0 \mathrm{mg} / \mathrm{dl}$ ou $-45,3 \%$ para $150 \mathrm{mg}$ e $-5,4$ $\mathrm{mg} / \mathrm{dl}$ ou $-82,2 \%$ para $300 \mathrm{mg})$ do que mistas $(-2,5 \mathrm{mg} / \mathrm{dl}$ ou $-20,4 \%$ para $150 \mathrm{mg}$ e $-2,81$ $\mathrm{mg} / \mathrm{dl}$ ou $-22,6 \%$ para $300 \mathrm{mg})$ ou predominantemente volumosas $(+1,7 \mathrm{mg} / \mathrm{dl}$ ou $+18,4 \%$ para $150 \mathrm{mg}$ e $-0,6 \mathrm{mg} / \mathrm{dl}$ ou $-6,7 \%$ para $300 \mathrm{mg}$ ). Como demonstrado, seja em doses altas ou em doses baixas, a monensina causou maiores decréscimos sobre a concentração ruminal de nitrogênio amoniacal em dietas predominantemente concentradas, quando comparada com as predominantemente volumosas.

Alguns trabalhos não demostraram efeito dos níveis de ionóforos sobre a concentração ruminal de amônia, como é o caso dos dados obtidos por Funk et al. (1986), Jacques et al. (1987), Dye et al. (1988), Reffett-Stabel et al. (1989), Morris et al. (1990), Wessels et al. (1996), Castro (1998) e Amaro (1999) ao utilizarem a lasalocida, e Branine \& Galyean (1990) e Fredrickson et al. (1993) ao utilizarem a monensina. Os dados obtidos neste experimento discordam dos citados acima e também da observação de Ramanzin et al. (1997), os quais demonstraram ser a ausência de efeito sobre a concentração ruminal de nitrogênio amoniacal independente da dieta utilizada, ou ainda de Garcia-Lopez et al. (1996), de que a falta de efeito da monensina sobre essa variável independia da proporção de concentrados no meio de cultura. 
Cabe lembrar que a literatura indica ser maior o efeito da monensina, quando comparada à lasalocida, em diminuir as concentrações de amônia. Starnes et al. (1984) demostraram que os ionóforos diminuem a atividade ureolítica ruminal e este efeito foi maior para a monensina quando comparada à lasalocida. Ricke et al. (1984) observaram que somente a monensina diminuiu as concentrações ruminais de amônia, enquanto que a lasalocida, embora não tenha aumentado as concentrações, aumentou as reservas ruminais deste composto. Ainda, Clary et al. (1993) demonstraram que a lasalocida aumentou as concentrações ruminais de amônia quando combinada com gordura, efeito que não foi observado com a monensina. O efeito da monensina em aumentar as concentrações de nitrogênio amoniacal no meio de cultura foi demonstrado por Machado (1988).

Kats et al. (1986) não observaram diferenças entre a monensina e lasalocida em diminuir as concentrações de amônia, entretanto foi registrado que este efeito, em diminuir as concentrações de amônia, desaparecia com a adaptação dos animais aos produtos, fato que não foi observado no presente experimento até 21 dias depois de iniciado o tratamento. 
Tabela 21. Efeitos da proporção de concentrados (Con) e dose de monensina (Mon) sobre as concentrações ruminais de nitrogênio amoniacal $(\mathrm{mg} / \mathrm{dl})$, em diferentes horas de amostragem, coeficientes de variação (CV) e probabilidades estatísticas no experimento com bovinos.

\begin{tabular}{|c|c|c|c|c|c|c|c|c|c|}
\hline \multicolumn{2}{|c|}{ Tratamentos } & \multicolumn{7}{|c|}{ Tempo (horas) } & \multirow[b]{2}{*}{ Média } \\
\hline Con & Mon & 0 & 2 & 4 & 6 & 8 & 10 & 12 & \\
\hline \multicolumn{10}{|c|}{ Interações } \\
\hline \multirow{3}{*}{25} & 0 & 6,06 & 12,08 & 9,12 & 8,78 & 7,44 & 6,10 & 4,36 & 7,71 \\
\hline & 150 & 10,60 & 14,20 & 10,80 & 9,70 & 7,94 & 7,05 & 6,49 & 9,54 \\
\hline & 300 & 4,77 & 11,24 & 8,51 & 7,41 & 5,76 & 4,81 & 2,56 & 6,44 \\
\hline \multirow{3}{*}{50} & 0 & 10,85 & 18,25 & 12,43 & 8,11 & 7,59 & 7,40 & 7,85 & 10,35 \\
\hline & 150 & 9,80 & 16,20 & 9,90 & 7,79 & 7,08 & 6,58 & 7,07 & 9,20 \\
\hline & 300 & 9,04 & 14,43 & 9,62 & 6,29 & 5,07 & 5,14 & 5,52 & 7,87 \\
\hline \multirow{3}{*}{75} & 0 & 12,77 & 13,84 & 6,51 & 4,33 & 4,06 & 4,20 & 5,23 & 7,28 \\
\hline & 150 & 8,50 & 11,50 & 3,56 & 1,93 & 2,89 & 3,19 & 4,39 & 5,14 \\
\hline & 300 & 7,17 & 11,05 & 1,16 & 0,74 & 1,36 & 2,44 & 3,95 & 3,98 \\
\hline \multicolumn{10}{|c|}{ Efeitos Principais } \\
\hline 25 & & 7,14 & 12,51 & 9,48 & 8,63 & 7,05 & 5,99 & 4,47 & 7,89 \\
\hline 50 & & 9,90 & 16,29 & 10,65 & 7,40 & 6,58 & 6,37 & 6,81 & 9,14 \\
\hline \multirow[t]{4}{*}{75} & & 9,48 & 12,13 & 3,74 & 2,33 & 2,77 & 3,27 & 4,52 & 5,47 \\
\hline & 0 & 9,89 & 14,73 & 9,35 & 7,07 & 6,36 & 5,90 & 5,81 & 8,45 \\
\hline & 150 & 9,63 & 13,97 & 8,09 & 6,47 & 5,97 & 5,61 & 5,98 & 7,96 \\
\hline & 300 & 6,99 & 12,24 & 6,43 & 4,81 & 4,06 & 4,13 & 4,01 & 6,10 \\
\hline \multicolumn{10}{|c|}{ Dados Médios } \\
\hline \multirow{2}{*}{\multicolumn{2}{|c|}{$\begin{array}{l}\text { Média } \\
\text { CV }\end{array}$}} & 8,84 & 13,64 & 7,96 & 6,12 & 5,47 & 5,21 & 5,27 & 7,50 \\
\hline & & 36,47 & 25,61 & 48,59 & 57,05 & 49,68 & 38,28 & 42,19 & 55,25 \\
\hline \multicolumn{10}{|c|}{ Probabilidades Estatísticas } \\
\hline \multicolumn{10}{|c|}{ Concentrado } \\
\hline \multicolumn{2}{|c|}{ Linear (L) } & NS & NS & 0,0001 & 0,0001 & 0,0001 & 0,0005 & NS & 0,0060 \\
\hline \multicolumn{2}{|c|}{ Desvio (D) } & NS & 0,0050 & 0,0001 & 0,0241 & 0,0371 & 0,0049 & 0,0080 & 0,0019 \\
\hline \multicolumn{10}{|c|}{ Monensina } \\
\hline \multicolumn{2}{|c|}{ Linear (L) } & 0,0235 & NS & 0,0037 & 0,0214 & 0,0155 & 0,0113 & NS & 0,0075 \\
\hline \multicolumn{2}{|c|}{ Desvio (D) } & NS & NS & NS & NS & NS & NS & NS & NS \\
\hline \multicolumn{10}{|c|}{ Interação } \\
\hline Con & $\operatorname{mon}_{\mathrm{L}}$ & NS & NS & 0,0387 & NS & NS & NS & NS & NS \\
\hline Con & $\operatorname{mon}_{D}$ & 0,0155 & NS & NS & NS & NS & NS & NS & NS \\
\hline Con & $\operatorname{mon}_{\mathrm{L}}$ & NS & NS & NS & NS & NS & NS & NS & NS \\
\hline Con & $\operatorname{mon}_{\mathrm{D}}$ & NS & NS & NS & NS & NS & NS & NS & NS \\
\hline
\end{tabular}


Tabela 21. Efeitos da proporção de concentrados (Con) e dose de monensina (Mon) sobre as concentrações ruminais de nitrogênio amoniacal $(\mathrm{mg} / \mathrm{dl})$, em diferentes horas de amostragem, coeficientes de variação $(\mathrm{CV})$ e probabilidades estatísticas no experimento com bovinos.

\begin{tabular}{|c|c|}
\hline Causas de variação & $\begin{array}{c}\text { Probabilidades } \\
\text { Estatísticas }\end{array}$ \\
\hline Tempo & 0,0001 \\
\hline \multicolumn{2}{|l|}{ Tempo X concentrado (Con) } \\
\hline Tempo $\mathrm{X}$ con $_{\text {Linear }}$ & 0,0001 \\
\hline Tempo $X$ con $_{\text {Desvio }}$ & 0,0031 \\
\hline \multicolumn{2}{|l|}{ Tempo X monensina (Mon) } \\
\hline Tempo $X$ mon $_{\text {Linear }}$ & NS \\
\hline Tempo X mon Desvio & NS \\
\hline \multicolumn{2}{|l|}{ Tempo X concentrado X monensina } \\
\hline Tempo X con $_{\text {Linear }} X$ mon $_{\text {Linear }}$ & NS \\
\hline Tempo X con Linear $\mathrm{X}$ mon Desvio & NS \\
\hline Tempo $X$ con $_{\text {Desvio }} \mathrm{X}$ mon $_{\text {Linear }}$ & NS \\
\hline Tempo $\mathrm{X}$ con $_{\text {Desvio }} \mathrm{X}$ mon $_{\text {Desvio }}$ & NS \\
\hline
\end{tabular}




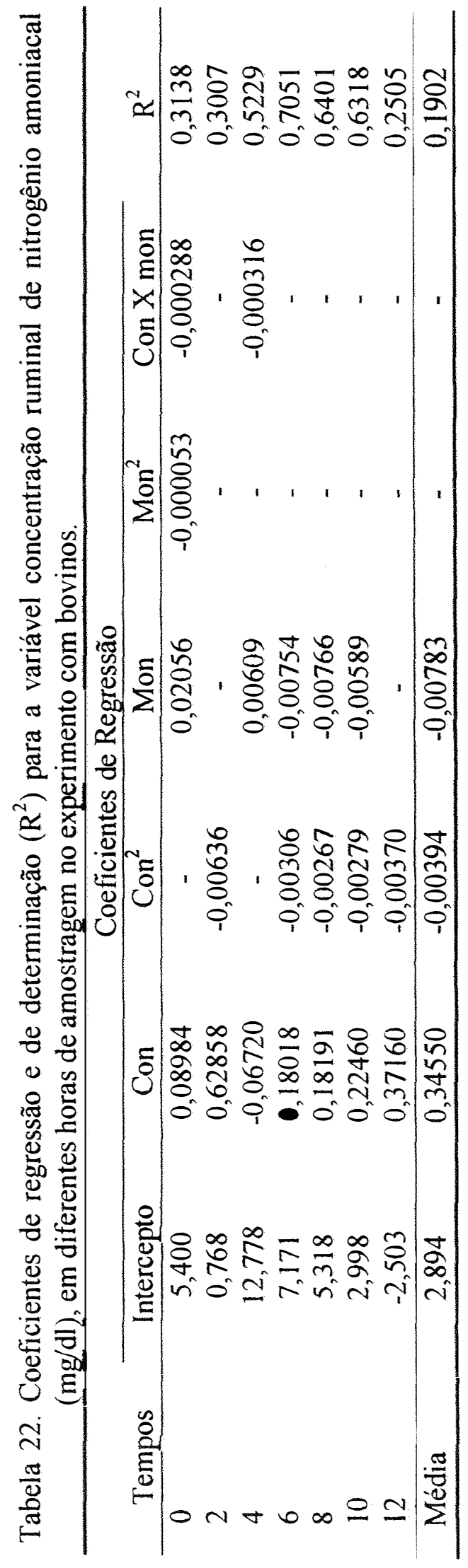



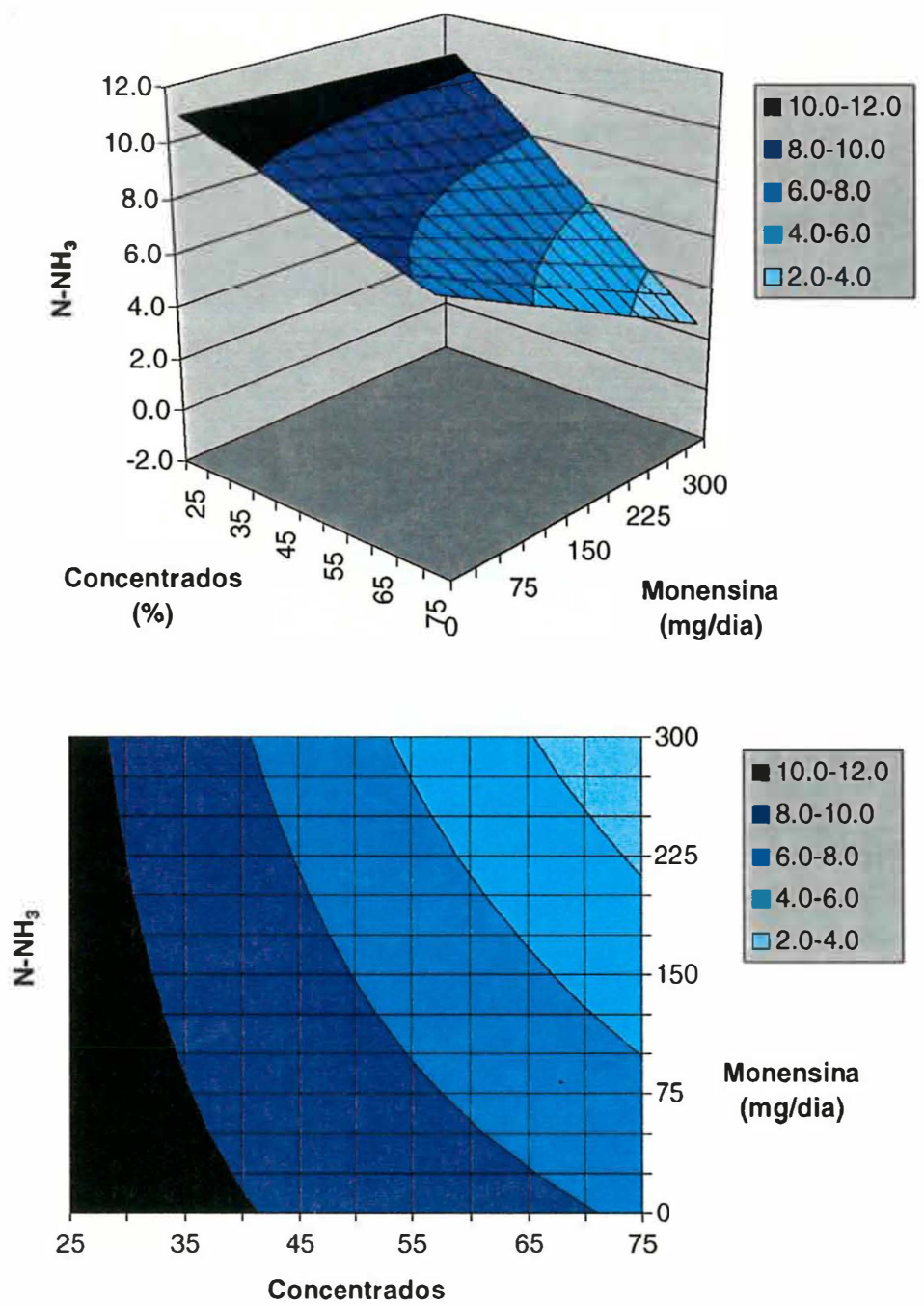

(\%)

Figura 11 - Efeitos da proporção de concentrados (\% da dieta) e dose de monensina (mg/animal/dia) sobre a concentração ruminal de nitrogênio amoniacal $(\mathrm{mg} / \mathrm{dl}) 4$ horas após a alimentação, obtido no experimentos com bovinos. 


\subsection{Digestibilidade ruminal in situ da fibra do feno}

A utilização de aproximadamente 5 gramas de alimento dentro dos sacos (tamanho médio de $10 \times 19 \mathrm{~cm}$ ) resultou na proporção de 13,2 mg de amostra por centímetro quadrado de superficie, valor abaixo dos $5 \mathrm{~g}$ para sacos de $9 \times 17 \mathrm{~cm}$ $\left(16,4 \mathrm{mg} / \mathrm{cm}^{2}\right)$ recomendados por Mehres \& Ørskov (1977) e dos $15 \mathrm{mg} / \mathrm{cm}^{2}$ indicados por Lindberg (1981c) como limite máximo para que não haja diminuição significativa sobre o desaparecimento da MS.

Nas condições do presente experimento, estima-se que a taxa de passagem de sólidos pelo rúmen dos animais esteja entre os valores de $0,02 / \mathrm{h}$ a $0,05 / \mathrm{h}$ (A.F.R.C., 1992). Para o cálculo da degradabilidade efetiva dos alimentos aqui testados foram utilizados valores iguais a $0,02 / \mathrm{h}, 0,05 / \mathrm{h}$ e $0,08 / \mathrm{h}$.

A Tabela 23 traz a composição bromatológica do feno utilizado no ensaio de digestibilidade ruminal in situ e as Tabelas 24,26 e 28 trazem respectivamente os dados de digestibilidade ruminal in situ da MS, FDN e FDA do feno de Tifton 85 obtidos no experimento com bovinos.

Não foram observados quaisquer efeitos dos fatores que compõem os tratamentos utilizados neste experimento sobre a fração rapidamente solúvel (parâmetro $a$ do modelo utilizado) da MS, FDN ou FDA do feno de Tifton 85, embora a proporção de concentrados tenha causado resposta curvilinear sobre a fração potencialmente degradável (parâmetro $b$ do modelo utilizado) da MS, FDN ou FDA do feno, com maiores resultados observados para as dietas mistas, enquanto que a dose de monensina resultou em diminuição linear deste parâmetro somente para a MS do feno. A taxa de degradação (parâmetro $c$ do modelo utilizado) apresentou-se negativamente influenciado pela proporção de concentrados na dieta, tendo esta resposta apresentado um comportamento linear para a MS, FDN ou FDA do feno. A dosagem de monensina não influenciou a taxa de degradação para qualquer fração do feno estudada. 
Estes parâmetros obtidos resultaram em uma interação dos fatores proporção de concentrados na dieta com a dosagem de monensina administrada aos animais para as degradabilidades efetivas da MS e FDN calculadas para taxas de passagem de $2 \%, 5 \%$ e $8 \%$, bem como para a degradabilidade efetiva da FDA, quando calculada para a taxa de passagem de $2 \%$ somente. Em todos os casos, a resposta foi linear para o efeito de proporção de concentrados (menor a degradabilidade, quanto maior a proporção de concentrados) e curvilinear para a dosagem de monensina (maior a degradabilidade para dosagens intermediárias).

Para a MS do feno, a adição de monensina à dieta diminuiu a degradabilidade efetiva deste parâmetro em até 2,2 unidades percentuais $(4,6 \%)$, independentemente da taxa de passagem de MS utilizada, quando adicionada às dietas predominantemente volumosas ou mistas. Já as doses elevadas de monensina (300 $\mathrm{mg} / \mathrm{animal} / \mathrm{dia}$ ) diminuíram a degradabilidade efetiva da MS entre 3,3 e até 6,3 unidades percentuais $(13,7 \%$ a $14,6 \%)$, quando adicionadas a dietas predominantemente concentradas, sendo as maiores quedas observadas para degradabilidades calculadas com taxas de passagem da matéria seca mais baixas $(0,02 / \mathrm{h})$ e, portanto, com maior tempo de permanência do alimento no rúmen. Entretanto, doses medianas do produto (150 mg/animal/dia) não causaram queda na degradabilidade efetiva da MS nessas dietas pobres em fibra, tendo inclusive apresentado tendência em aumentá-la.

Para a degradabilidade efetiva da FDN (Figura 12), as quedas causadas por doses elevadas de monensina ( $300 \mathrm{mg} / \mathrm{animal} / \mathrm{dia}$ ) em dietas predominantemente concentradas variaram entre 4,1 a 6,9 unidades percentuais $(17,8 \%$ a $25,9 \%)$, com as maiores quedas, quando expressas em unidades percentuais, também observadas para degradabilidades calculadas com taxas de passagem mais baixas. Foi também nessas condições de altos níveis de concentrados na dieta que a adição de doses intermediárias de monensina ( $150 \mathrm{mg} / \mathrm{animal} / \mathrm{dia}$ ) causou os maiores aumentos da degradabilidade efetiva da fibra, da ordem de 3,2 a 4,0 unidades percentuais $(8,3 \%$ a $23,0 \%)$.

Para a degradabilidade efetiva da FDA, efeito de interação foi demonstrado somente quando este parâmetro foi calculado para taxas de passagem 
baixas $(0,02 / \mathrm{h})$, com o mesmo padrão de resposta que a degradabilidade da MS e FDN, sendo a maior depressão obtida ( 8,23 unidades percentuais ou $22,4 \%)$ com a combinação de doses elevadas de monensina em dietas ricas em concentrados.

A menor degradação da fibra em dietas ricas em concentrados estaria associada ao menor $\mathrm{pH}$ ruminal, fato que poderia diminuir a atividade da celulolase microbiana ruminal, como demonstrado por Mould et al. (1983).

Com relação à monensina, os dados aqui obtidos parecem justificar a enorme gama de resultados encontrados na literatura com a utilização dos ionóforos em diferentes condições ruminais. É curioso como a condição de fermentação ruminal, obtida com altos níveis de concentrados, que tenha permitido as maiores respostas em termos de degradabilidade efetiva da fibra, ao se utilizar doses intermediárias do produto, também tenha sido a mesma condição que propiciou as piores respostas deste parâmetro, quando doses altas foram utilizadas.

Isto talvez venha a confirmar resultados de diminuição do desaparecimento in vivo da celulose em animais alimentados com dieta predominantemente concentrada adicionada de monensina (Lemenager et al., 1978), da degradação da fibra em vacas leiteiras recebendo dietas mistas (Haimoud et al., 1995) ou novilhas recebendo dietas volumosas (Haimoud et al., 1996) adicionadas de monensina e mesmo do aumento da digestibilidade ou degradabilidade da fibra ao adicionar monensina (Faulkner et al., 1985; Branine \& Galyean, 1990), lasalocida (Richter \& Flachowisk, 1990; Castro, 1998) e lasalocida ou monensina (Tanner et al., 1984; Galloway et al., 1993) em dietas predominantemente volumosas. Talvez também venha confirmar a falta efeitos significativos da lasalocida ou monensina sobre a taxa de desaparecimento da celulose quando incubada no rúmen de ovinos alimentados com $67 \%$ de volumoso (Ricke et al., 1984) ou a falta de efeitos da lasalocida sobre a taxa de desaparecimento da FDN quando incubada no rúmen de novilhas recebendo dieta mista (50\% de concentrados) (Peixoto Jr., 1998).

Resultados compatíveis com os apresentados por Ricke et al. (1984) foram obtidos por Bogaert et al. (1991) ao administrarem lasalocida a ovinos recebendo 
dieta com $68 \%$ de volumoso (dieta com $40 \%$ de FDN). Esses autores também não observaram efeitos significativos sobre a degradabilidade in situ da celulose quando esta foi incubada durante 24 horas, apesar do desaparecimento desta fração ter sido $27,0 \%$ menor (não significativamente menor) com a utilização da lasalocida. Das constantes utilizadas no presente experimento, as taxas de degradação da MS, FDN ou FDA (constante $c$ ) apresentaram coefícientes de variação bastante altos $(19,5 \%$ a $20,9 \%)$, quando comparadas aos outros parâmetros, fato que desencoraja sua utilização como indicador dos resultados obtidos sobre a degradabilidade da fibra em experimentos futuros.

Bogaert et al. (1991) também afirmaram que o efeito dos ionóforos sobre a degradação dos alimentos, quando colocados no pró-ventrículo em sacos de náilon, variava de acordo o tempo de incubação, tendendo a diminuir, proporcionalmente, a degradação da fração rapidamente degradável (parâmetro a da equação de Ørskov \& McDonald, 1979) e aumentar a fração potencialmente degradável (parâmetro $b$ ) e a taxa de desaparecimento (parâmetro $c$ ) de forma que a lasalocida poderia incrementar a degradação ruminal da fibra quando o tempo de incubação fosse alto e poderia diminuíla quando o tempo fosse baixo. Os resultados aqui encontrados mostraram-se diferentes, de forma que seria maior o efeito dos ionóforos sobre a degradação da fibra, sejam eles desejáveis ou não, quanto mais tempo ela ficasse exposta ao produto no rúmen.

Apesar deste experimento não permitir conclusões a respeito dos efeitos dos ionóforos sobre a microbiota ruminal, é possivel inferir que $\mathrm{pH}$ ruminal e dose de monensina interajam conjuntamente sobre as bactérias celulolíticas. Fato esse confirmado por Chen \& Wolin (1979), ao demostrarem que esses compostos exercem ação seletiva sobre as bactérias, de forma que as Gram negativas teriam vantagens sobre as Gram positivas. Desta forma, tanto os baixos valores de $\mathrm{pH}$ ruminal, como altas dose de monensina, seriam deletérios a essas bactérias. Entretanto, em algumas condições poderia-se esperar que a monensina anulasse os efeitos deletérios do baixo $\mathrm{pH}$, sem contudo expressar seus próprios efeitos negativos. Ao considerar uma condição cuja dieta apresentasse alto nível de fibra, e portanto alto $\mathrm{pH}$ ruminal, as bactérias 
celulolíticas estariam íntegras e a ausência de melhora no $\mathrm{pH}$ ruminal possivelmente causada pela monensina não traria vantagens a essas bactérias. Ao contrário, a monensina apenas expressaria seu efeito inibidor sobre essas bactérias, diminuindo a sua atividade celulolítica e, portanto, a degradação da fibra. Já em uma condição cuja dieta apresentasse alto nível de concentrados, e portanto baixo $\mathrm{pH}$ ruminal, as bactérias celulolíticas estariam comprometidas e uma melhora no $\mathrm{pH}$ ruminal causada por doses baixas de monensina poderia trazer vantagens a essas bactérias. Entretanto, doses altas do produto associadas a uma menor melhora adicional do $\mathrm{pH}$ se somariam causando uma grande depressão da atividade desse grupo de bactérias e, portanto, sobre a degradação da fibra.

As afirmações aqui realizadas são parcialmente confirmadas por Branine \& Galyean (1990), ao afirmarem que os possíveis efeitos indiretos dos ionóforos sobre a degradação da fibra no rúmen poderiam ser explicados pelo efeito destes compostos sobre o $\mathrm{pH}$ do líquido ruminal.

Caso as interações observadas neste experimento sejam comprovadas na prática, o grande efeito negativo de doses elevadas de monensina sobre 0 aproveitamento da fibra em dietas predominantemente concentradas, portanto com baixo nível de fibra para ser degradada, trariam resultados maléficos. Porém, estes resultados são de menor importância quando comparados aos pequenos resultados maléficos obtidos com a diminuição da degradação da fibra, mesmo que pequena por ação dos ionóforos, em dietas predominantemente volumosas, onde a maior fonte de energia provém desta fração.

Tabela 23. Composição bromatológica do feno utilizado no ensaio de digestibilidade ruminal in situ, com base na matéria seca.

\begin{tabular}{lccccccc}
\hline & \multicolumn{7}{c}{ Composição } \\
\cline { 2 - 8 } & MS & PB & FB & EE & MM & FDA & FDN \\
\hline Feno & 91,40 & 12,74 & 30,58 & 1,21 & 9,46 & 36,10 & 72,06 \\
\hline
\end{tabular}


Tabela 24. Efeitos da proporção de concentrados (Con) e dose de monensina (Mon) sobre a digestibilidade ruminal in situ da MS do feno de Tifton 85, coeficientes de variação $(\mathrm{CV})$ e probabilidades estatísticas no experimento com bovinos.

\begin{tabular}{|c|c|c|c|c|c|c|c|c|}
\hline \multicolumn{2}{|c|}{ Tratamentos } & \multicolumn{7}{|c|}{ Parâmetros ${ }^{1}$} \\
\hline Con & Mon & $a$ & $b$ & $c$ & De $2 \%$ & De $5 \%$ & De $8 \%$ & $\mathrm{Dp}$ \\
\hline \multicolumn{9}{|c|}{ Interações } \\
\hline \multirow{3}{*}{25} & 0 & 10,41 & 59,10 & 0,0357 & 48,27 & 35,01 & 28,64 & 69,51 \\
\hline & 150 & 10,06 & 60,70 & 0,0317 & 47,12 & 33,51 & 27,22 & 70,76 \\
\hline & 300 & 10,81 & 58,18 & 0,0310 & 46,07 & 32,99 & 27,00 & 69,00 \\
\hline \multirow{3}{*}{50} & 0 & 9,79 & 64,09 & 0,0269 & 45,94 & 31,82 & 25,66 & 73,88 \\
\hline & 150 & 10,43 & 63,02 & 0,0266 & 46,11 & 32,11 & 26,01 & 73,44 \\
\hline & 300 & 9,68 & 60,18 & 0,0297 & 45,58 & 32,06 & 25,94 & 69,86 \\
\hline \multirow{3}{*}{75} & 0 & 9,88 & 60,84 & 0,0242 & 43,02 & 29,64 & 23,97 & 70,72 \\
\hline & 150 & 11,46 & 58,51 & 0,0276 & 45,23 & 32,15 & 26,38 & 69,97 \\
\hline & 300 & 10,02 & 53,51 & 0,0200 & 36,72 & 25,27 & 20,69 & 63,53 \\
\hline \multicolumn{9}{|c|}{ Efeitos Principais } \\
\hline 25 & & 10,43 & 59,33 & 0,0328 & 47,15 & 33,84 & 27,62 & 69,76 \\
\hline 50 & & 9,97 & 62,43 & 0,0277 & 45,88 & 32,00 & 25,87 & 72,39 \\
\hline \multirow[t]{4}{*}{75} & & 10,51 & 58,14 & 0,0244 & 42,28 & 29,49 & 24,05 & 68,64 \\
\hline & 0 & 10,03 & 61,34 & 0,0289 & 45,74 & 32,16 & 26,09 & 71,37 \\
\hline & 150 & 10,65 & 60,74 & 0,0286 & 46,15 & 32,59 & 26,54 & 71,39 \\
\hline & 300 & 10,19 & 57,76 & 0,0277 & 43,55 & 30,71 & 25,02 & 67,95 \\
\hline \multicolumn{9}{|c|}{ Dados Médios } \\
\hline \multirow{2}{*}{\multicolumn{2}{|c|}{$\begin{array}{l}\text { Média } \\
\text { CV }\end{array}$}} & 10,29 & 60,13 & 0,0285 & 45,21 & 31,86 & 25,92 & 70,33 \\
\hline & & 12,99 & 6,01 & 19,52 & 7,35 & 9,36 & 9,92 & 4,73 \\
\hline \multicolumn{9}{|c|}{ Probabilidades Estatísticas } \\
\hline \multicolumn{9}{|c|}{ Concentrado } \\
\hline \multicolumn{2}{|c|}{ Linear $(\mathrm{L})$} & NS & NS & 0,0016 & 0,0001 & 0,0004 & 0,0009 & NS \\
\hline \multicolumn{2}{|c|}{ Desvio (D) } & NS & 0,0033 & NS & NS & NS & NS & 0,0064 \\
\hline \multicolumn{9}{|c|}{ Monensina } \\
\hline \multicolumn{2}{|c|}{ Linear $(\mathrm{L})$} & 0,0078 & NS & NS & NS & NS & NS & 0,0089 \\
\hline \multicolumn{2}{|c|}{ Desvio (D) } & NS & NS & NS & NS & NS & NS & NS \\
\hline \multicolumn{9}{|c|}{ Interação } \\
\hline Con & $\operatorname{lon}_{\mathrm{L}}$ & NS & NS & NS & NS & NS & NS & NS \\
\hline Con & $\operatorname{lon}_{\mathrm{D}}$ & NS & NS & NS & 0,0270 & 0,0329 & 0,0339 & NS \\
\hline Con & $\operatorname{lon}_{\mathrm{L}}$ & NS & NS & NS & NS & NS & NS & NS \\
\hline Con & $\operatorname{son}_{D}$ & NS & NS & NS & NS & NS & NS & NS \\
\hline
\end{tabular}

${ }^{1} a, b$ e $c$ referem-se aos paràmetros de Ørskov \& McDonald (1979), $\mathrm{De}=$ degradabilidade efetiva para taxas de passagem iguais a $0,02,0,05$ e 0,08 e $\mathrm{Dp}=$ degradabilidade potencial. 


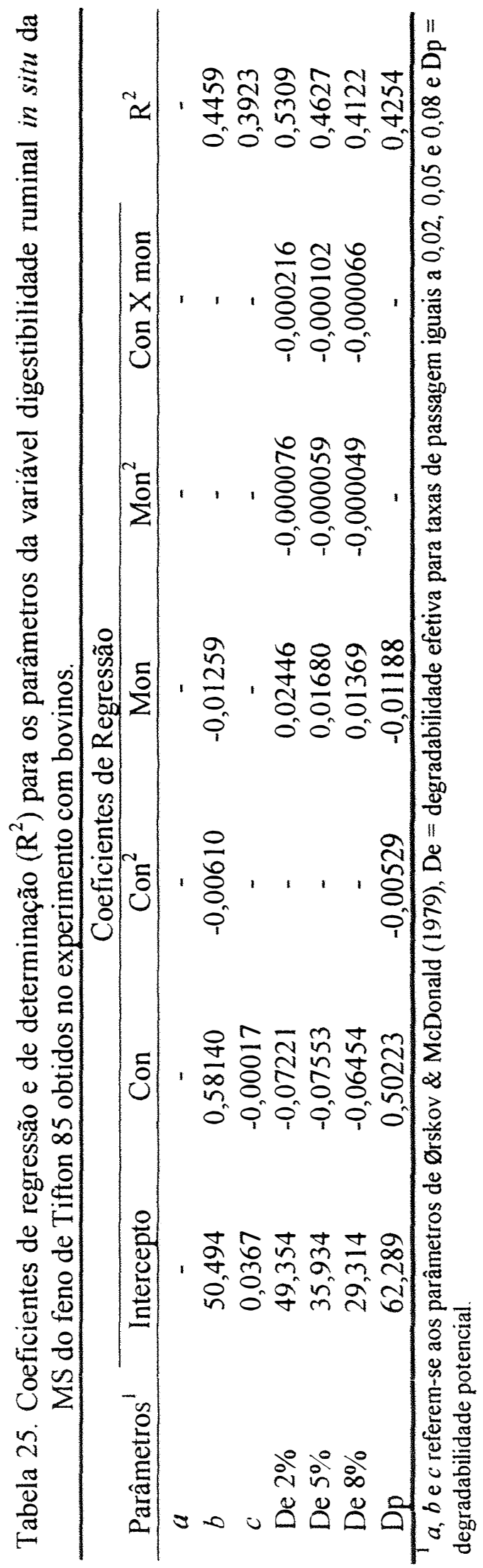


Tabela 26. Efeitos da proporção de concentrados (Con) e dose de monensina (Mon) sobre a digestibilidade ruminal in situ da FDN do feno de Tifton 85, coeficientes de variação $(\mathrm{CV})$ e probabilidades estatísticas no experimento com bovinos.

\begin{tabular}{|c|c|c|c|c|c|c|c|c|}
\hline \multicolumn{2}{|c|}{ Tratamentos } & \multicolumn{7}{|c|}{ Parâmetros ${ }^{1}$} \\
\hline Con & Mon & $a$ & $b$ & $c$ & De $2 \%$ & De $5 \%$ & De $8 \%$ & $\mathrm{Dp}$ \\
\hline \multicolumn{9}{|c|}{ Interaçōes } \\
\hline \multirow{3}{*}{25} & 0 & $-1,19$ & 69,00 & 0,0413 & 45,22 & 29,96 & 22,25 & 67,80 \\
\hline & 150 & $-2,36$ & 72,14 & 0,0349 & 43,43 & 27,26 & 19,54 & 69,78 \\
\hline & 300 & $-1,00$ & 69,43 & 0,0358 & 43,34 & 27,80 & 20,34 & 68,44 \\
\hline \multirow{3}{*}{50} & 0 & $-2,52$ & 74,05 & 0,0324 & 42,54 & 26,08 & 18,47 & 71,53 \\
\hline & 150 & $-1,17$ & 72,42 & 0,0303 & 42,24 & 26,00 & 18,61 & 71,24 \\
\hline & 300 & $-2,47$ & 72,28 & 0,0317 & 41,77 & 25,52 & 18,01 & 69,81 \\
\hline \multirow{3}{*}{75} & 0 & $-2,51$ & 70,93 & 0,0279 & 38,70 & 22,84 & 15,81 & 68,42 \\
\hline & 150 & 0,04 & 68,81 & 0,0322 & 41,92 & 26,54 & 19,44 & 68,84 \\
\hline & 300 & $-2,09$ & 65,98 & 0,0213 & 31,83 & 17,54 & 11,72 & 63,89 \\
\hline \multicolumn{9}{|c|}{ Efeitos Principais } \\
\hline 25 & & $-1,52$ & 70,19 & 0,0373 & 44,00 & 28,34 & 20,71 & 68,67 \\
\hline 50 & & $-2,05$ & 72,92 & 0,0315 & 42,18 & 25,87 & 18,36 & 70,86 \\
\hline \multirow[t]{4}{*}{75} & & $-1,45$ & 68,90 & 0,0278 & 38,19 & 22,90 & 16,15 & 67,45 \\
\hline & 0 & $-2,07$ & 71,33 & 0,0339 & 42,15 & 26,29 & 18,84 & 69,25 \\
\hline & 150 & $-1,17$ & 71,12 & 0,0325 & 42,53 & 26,60 & 19,20 & 69,96 \\
\hline & 300 & $-1,82$ & 69,64 & 0,0306 & 39,87 & 24,38 & 17,31 & 67,82 \\
\hline \multicolumn{9}{|c|}{ Dados Médios } \\
\hline \multirow{2}{*}{\multicolumn{2}{|c|}{$\begin{array}{l}\text { Média } \\
\text { CV }\end{array}$}} & $-1,68$ & 70,74 & 0,0324 & 41,58 & 25,81 & 18,49 & 69,05 \\
\hline & & 108,2 & 5,19 & 20,86 & 9,23 & 14,67 & 18,34 & 4,24 \\
\hline \multicolumn{9}{|c|}{ Probabilidades Estatísticas } \\
\hline \multicolumn{9}{|c|}{ Concentrado } \\
\hline \multicolumn{2}{|c|}{ Linear (L) } & NS & NS & 0,0027 & 0,0001 & 0,0005 & 0,0015 & NS \\
\hline Des & & NS & 0,0138 & NS & NS & NS & NS & 0,0110 \\
\hline \multicolumn{9}{|c|}{ Monensina } \\
\hline Line & & NS & NS & NS & 0,0193 & NS & NS & NS \\
\hline Des & & NS & NS & NS & NS & NS & NS & NS \\
\hline \multicolumn{9}{|c|}{ Interação } \\
\hline Con & $\operatorname{on}_{\mathrm{L}}$ & NS & NS & NS & NS & NS & NS & NS \\
\hline Con & $\operatorname{con}_{\mathrm{D}}$ & NS & NS & NS & 0,0086 & 0.0133 & 0,0149 & NS \\
\hline Con & $\mathrm{non}_{\mathrm{L}}$ & NS & NS & NS & NS & NS & NS & NS \\
\hline Con & $\operatorname{non}_{D}$ & NS & NS & NS & NS & NS & NS & NS \\
\hline
\end{tabular}

${ }_{a, b} \mathrm{e} c$ referem-se aos paràmetros de Ørskov \& McDonald (1979), De $=$ degradabilidade efetiva para taxas de passagem iguais a $0,02,0,05$ e 0,08 e $\mathrm{Dp}=$ degradabilidade potencial. 


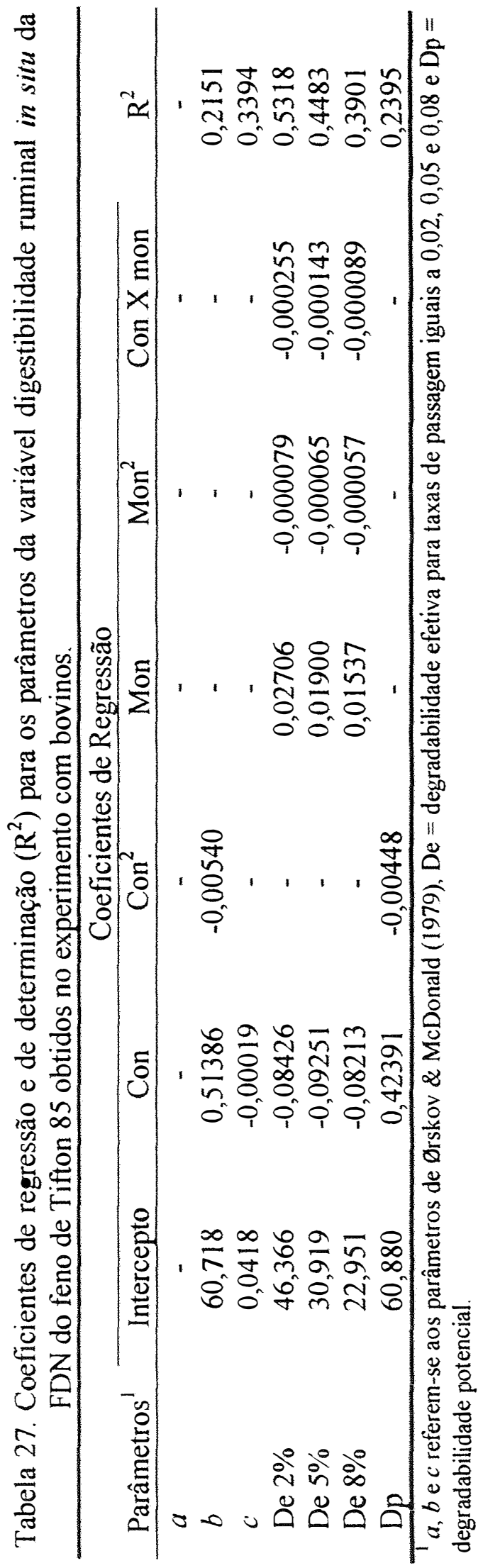



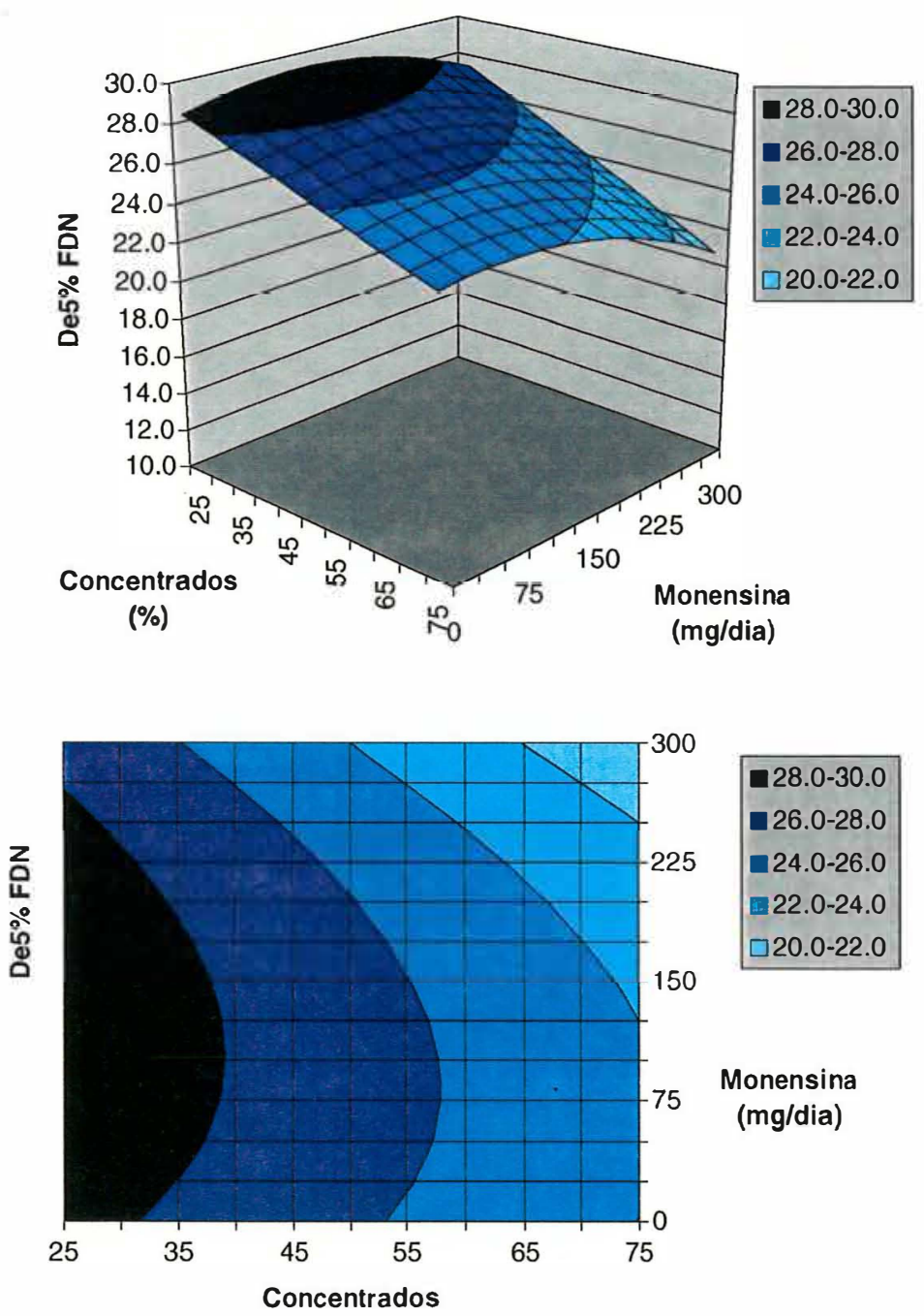

(\%)

Figura 12 - Efeitos da proporção de concentrados (\% da dieta) e dose de monensina (mg/animal/dia) sobre a degradabilidade efetiva da FDN do feno de Tifton 85 , quando calculada para taxa de passagem de 0,05 (De 5\%), obtidos no experimento com bovinos. 
Tabela 28. Efeitos da proporção de concentrados (Con) e dose de monensina (Mon) sobre a digestibilidade ruminal in situ da FDA do feno de Tifton 85, coeficientes de variação $(\mathrm{CV})$ e probabilidades estatísticas no experimento com bovinos.

\begin{tabular}{|c|c|c|c|c|c|c|c|c|}
\hline \multicolumn{2}{|c|}{ Tratamentos } & \multicolumn{7}{|c|}{ Parâmetros ${ }^{1}$} \\
\hline Con & Mon & $a$ & $b$ & $c$ & De $2 \%$ & De $5 \%$ & De $8 \%$ & Dp \\
\hline \multicolumn{9}{|c|}{ Interações } \\
\hline \multirow{3}{*}{25} & 0 & $-2,37$ & 69,70 & 0,0371 & 42,78 & 27,21 & 19,63 & 67,33 \\
\hline & 150 & $-2,68$ & 71,21 & 0,0320 & 40,95 & 24,98 & 17,58 & 68,53 \\
\hline & 300 & $-2,82$ & 70,12 & 0,0313 & 39,69 & 23,97 & 16,75 & 67,31 \\
\hline \multirow{3}{*}{50} & 0 & $-4,39$ & 74,76 & 0,0289 & 39,42 & 22,74 & 15,28 & 70,37 \\
\hline & 150 & $-3,23$ & 72,09 & 0,0301 & 39,94 & 23,76 & 16,40 & 68,86 \\
\hline & 300 & $-3,74$ & 73,61 & 0,0277 & 38,83 & 22,38 & 15,11 & 69,87 \\
\hline \multirow{3}{*}{75} & 0 & $-3,21$ & 72,74 & 0,0246 & 36,77 & 20,72 & 13,87 & 69,53 \\
\hline & 150 & $-2,19$ & 71,24 & 0,0274 & 38,49 & 22,66 & 15,71 & 69,05 \\
\hline & 300 & $-4,40$ & 66,72 & 0,0200 & 28,54 & 14,32 & 8,68 & 62,32 \\
\hline \multicolumn{9}{|c|}{ Efeitos Principais } \\
\hline 25 & & $-2,62$ & 70,34 & 0,0335 & 41,14 & 25,38 & 17,98 & 67,72 \\
\hline 50 & & $-3,79$ & 73,49 & 0,0289 & 39,40 & 22,96 & 15,60 & 69,70 \\
\hline \multirow[t]{4}{*}{75} & & $-3,12$ & 70,67 & 0,0244 & 35,36 & 19,85 & 13,26 & 67,55 \\
\hline & 0 & $-3,32$ & 72,40 & 0,0302 & 39,65 & 23,56 & 16,26 & 69,08 \\
\hline & 150 & $-2,70$ & 71,51 & 0,0298 & 39,79 & 23,80 & 16,56 & 68,81 \\
\hline & 300 & $-3,56$ & 70,58 & 0,0270 & 36,58 & 20,96 & 14,12 & 67,02 \\
\hline \multicolumn{9}{|c|}{ Dados Médios } \\
\hline \multirow{2}{*}{\multicolumn{2}{|c|}{$\begin{array}{l}\text { Média } \\
\text { CV }\end{array}$}} & $-3,18$ & 71,53 & 0,0291 & 38,76 & 22,84 & 15,71 & 68,35 \\
\hline & & 56,89 & 5,42 & 20,24 & 10,40 & 17,08 & 22,26 & 4,67 \\
\hline \multicolumn{9}{|c|}{ Probabilidades Estatísticas } \\
\hline \multicolumn{9}{|c|}{ Concentrado } \\
\hline \multicolumn{2}{|c|}{ Linear (L) } & NS & NS & 0,0009 & 0,0002 & 0,0005 & 0,0010 & NS \\
\hline Des & & NS & 0,0226 & NS & NS & NS & NS & NS \\
\hline \multicolumn{9}{|c|}{ Monensina } \\
\hline \multicolumn{2}{|c|}{ Linear (L) } & NS & NS & NS & 0,0091 & 0,0333 & NS & NS \\
\hline Des & & NS & NS & NS & NS & NS & NS & NS \\
\hline \multicolumn{9}{|c|}{ Interação } \\
\hline \multicolumn{2}{|c|}{$\operatorname{Con}_{\mathrm{L}} \mathrm{Xmon}_{\mathrm{L}}$} & NS & NS & NS & NS & NS & NS & 0,0479 \\
\hline \multicolumn{2}{|c|}{$\mathrm{Con}_{\mathrm{L}} \mathrm{Xmon}_{\mathrm{D}}$} & NS & NS & NS & 0,0417 & NS & NS & NS \\
\hline \multicolumn{2}{|c|}{$\operatorname{Con}_{\mathrm{D}} \mathrm{Xmon}_{\mathrm{L}}$} & NS & NS & NS & NS & NS & NS & NS \\
\hline \multicolumn{2}{|c|}{ Con $_{\mathrm{D}} \mathrm{Xmon}_{\mathrm{D}}$} & NS & NS & NS & NS & NS & NS & NS \\
\hline
\end{tabular}

a, b e $c$ referem-se aos parâmetros de Ørskov \& McDonald (1979), De = degradabilidade efetiva para taxas de passagem iguais a $0,02,0,05$ e 0,08 e $\mathrm{Dp}=$ degradabilidade potencial. 


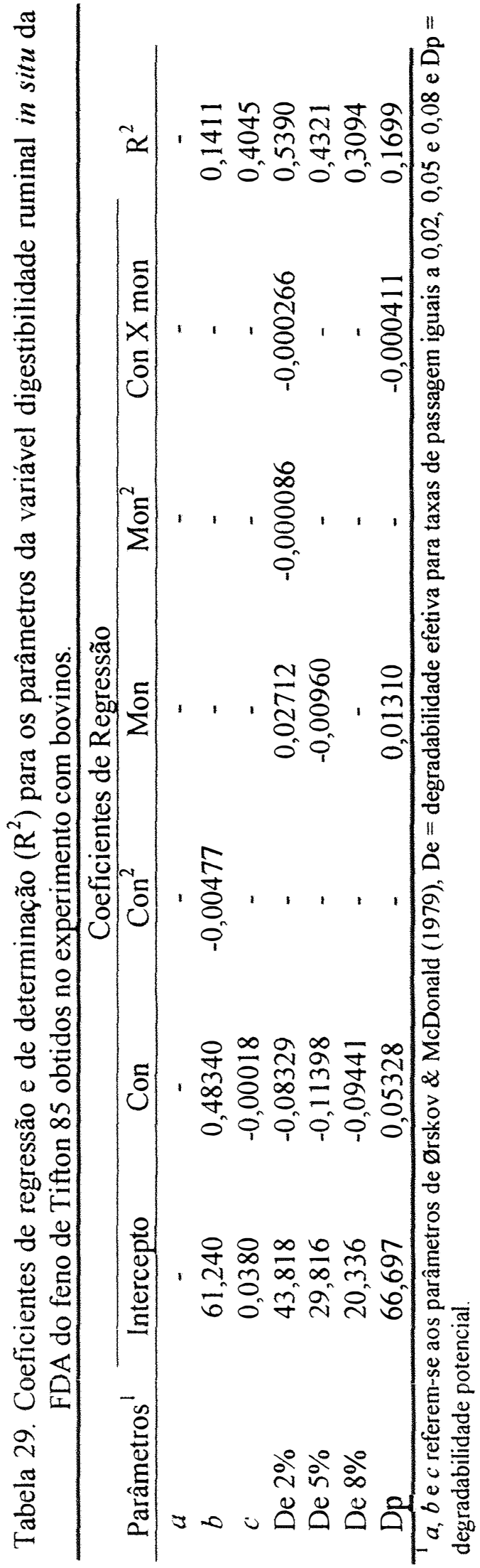




\subsection{Digestibilidade ruminal in situ da proteína do farelo de soja}

Os efeitos da dose de monensina e da proporção de concentrados na ração sobre os parâmetros da digestibilidade ruminal in situ da MS e PB do farelo de soja, obtidos no experimento com bovinos, encontram-se respectivamente nas Tabelas 30 e 32.

A monensina aumentou linearmente a constante $a$ (fração rapidamente degradável estimada a partir da equação de Ørskov \& McDonald, 1979) da MS do farelo de soja, em 2,0 a 3,0 unidades percentuais (7,6\% a 11,2\%), e da PB deste ingrediente em 3,2 a 4,8 unidades percentuais $(50,6 \%$ a $77,6 \%)$, mas diminuiu em 2,8 a 4,1 unidades percentuais $(3,8 \%$ a $5,5 \%)$ a constante $b$ (fração potencialmente degradável) da MS e em 4,2 a 5,6 unidades percentuais $(4,3 \%$ a 5,8\%) a constante $b$ da PB do farelo de soja, sem contudo causar qualquer efeito significativo sobre os demais parâmetros.

Já o aumento da proporção de concentrados na dieta diminuiu linearmente a taxa de degradação (constante $c$ do modelo adotado) da MS do farelo de soja em 0,028 a 0,046 unidades $(20,9 \%$ a $34,6 \%)$ e da PB em 0,030 a 0,056 unidades $(21,4 \%$ a $40,0 \%)$, quando comparadas com as dietas predominantemente volumosas. Tais efeitos resultaram em quedas lineares das degradabilidades efetivas da MS, quando calculadas para taxas de $5 \% / \mathrm{h}$ e $8 \% / \mathrm{h}$, de até 5,0 a 6,3 unidades percentuais $(6,4 \%$ a $8,6 \%$ ) e da $\mathrm{PB}$, quando calculadas para taxas de $2 \% / \mathrm{h}, 5 \% / \mathrm{h}$ e $8 \% / \mathrm{h}$, de até 4,0 a 11,0 unidades percentuais $(4,5 \%$ a $16,4 \%)$ ao se comparar as dietas com $75 \%$ de concentrados com aquelas contendo apenas $25 \%$. As degradabilidades potenciais $(a+b)$ da MS e PB do farelo aumentaram linearmente com a adição de concentrados, mas nenhum efeito foi observado com a adição de monensina.

Os fatores proporção de concentrados na dieta e dosagem de monensina não interagiram para qualquer dos parâmetros de digestibilidade ruminal in situ do farelo de soja estudados. 
O efeito da monensina em aumentar a fração solúvel (constante $a$ ) e diminuir a fração potencialmente degradável (constante $b$ ) sem, contudo, alterar a degradabilidade potencial $(a+b)$ indica que esse produto aumentou a degradação da PB, quando o alimento era exposto por curtos espaços de tempo ou quando a concentração do produto no rúmen era provavelmente alta, mas diminuía sua degradação quando o tempo de exposição era maior ou a concentração do produto provavelmente mais baixa. Não foi possível distinguir entre as duas possíveis causas com a metodologia aqui adotada.

Rodrigues (1996) e Castro (1998), ao utilizarem a mesma metodologia para estudar o efeito da lasalocida sobre a degradabilidade da proteína, encontraram resultados semelhantes, sendo que o primeiro autor postulou que os resultados gerados poderiam estar tendenciados em conseqüência da possível heterogeneidade de concentração do ionóforo no líquido ruminal ao longo do dia, fato que poderia resultar em maior ou menor efeito sobre os microorganismos ruminais, dependendo do tempo em que cada amostra foi incubada e da duração dos efeitos da aplicação dos ionóforos. Afirmou também o autor que, de qualquer forma, esta possibilidade implicaria em atividade proteolítica inibida, durante o prazo em que havia altas concentrações do ionóforo no líquido ruminal, mas aumentada quando esta concentração baixasse, podendo-se até anular os efeitos já obtidos.

Os dados encontrados no presente trabalho podem ser considerados diferentes, mas complementam aqueles que observaram diminuição da proteólise ruminal com conseqüente diminuição da síntese protéica bacteriana (Poos et al., 1979; Faulkner et al.,1985; Gomez et al., 1991) ou aumento do nitrogênio dietário que chegava ao duodeno em experimentos realizados com animais portando cânulas de duodeno (Zinn et al., 1994; Haimoud et al., 1995; Suber \& Bowman, 1998) ou, ainda, experimentos realizados in vitro (Whetstone et al., 1981). Ainda em ensaios in vitro, Van Nevel \& Demeyer (1977) demonstraram que a monensina diminuiu a degradação da proteína, sendo que a fonte de substrato energético adicionada ao meio de cultura (concentrados ou celobiose e maltose) não influenciou a resposta. 
Em contrapartida, Ricke et al. (1984), ao utilizarem a técnica dos sacos náilon em ovinos alimentados com dieta a base de $67 \%$ de volumoso, não observaram efeitos da monensina ou lasalocida sobre a taxa de desaparecimento in situ do nitrogênio do farelo de soja, apesar dos dados referentes às constantes da equação de degradação não terem sido apresentados. Peixoto Jr. (1998) também não demonstrou efeitos da lasalocida sobre a taxa de desaparecimento da PB do farelo de soja quando incubado no rúmen de novilhas recebendo dieta mista (50\% de concentrados).

Quanto ao nível de fibra da dieta, os resultados do presente experimento concordam com os obtidos por Ganev et al. (1979), Barrio et al. (1985), Barrio et al. (1986), Lindberg (1981a), Susmel et al. (1989), Weakley et al. (1983), os quais observaram menor degradabilidade da PB quanto mais altos os níveis de concentrados na dieta, possivelmente explicado pelo número e/ou atividade bacteriana (Barrio et al., 1985) ou efeito do baixo $\mathrm{pH}$ do conteúdo ruminal em inibir a atividade das proteases bacterianas (Barrio et al., 1986). Entretanto, os presentes dados discordam dos obtidos por Castrillo et al. (1992) e Lindberg (1981b) ao não observarem efeitos significativos da proporção de concentrados na dieta sobre a degradabilidade da proteína. 
Tabela 30. Efeitos da proporção de concentrados (Con) e dose de monensina (Mon) sobre a digestibilidade ruminal in situ da MS do farelo de soja, coeficientes de variação $(\mathrm{CV})$ e probabilidades estatísticas no experimento com bovinos.

\begin{tabular}{|c|c|c|c|c|c|c|c|c|}
\hline \multicolumn{2}{|c|}{ Tratamentos } & \multicolumn{7}{|c|}{ Parâmetros ${ }^{1}$} \\
\hline Con & Mon & $a$ & $b$ & $c$ & De $2 \%$ & De $5 \%$ & De $8 \%$ & $\mathrm{Dp}$ \\
\hline \multicolumn{9}{|c|}{ Interaçōes } \\
\hline \multirow{3}{*}{25} & 0 & 27,53 & 70,49 & 0,1296 & 88,05 & 77,58 & 70,26 & 98,02 \\
\hline & 150 & 28,87 & 69,14 & 0,1278 & 88,23 & 78,01 & 70,88 & 98,01 \\
\hline & 300 & 29,37 & 68,72 & 0,1442 & 89,06 & 79,43 & 72,57 & 98,09 \\
\hline \multirow{3}{*}{50} & 0 & 27,26 & 73,34 & 0,1004 & 88,00 & 75,65 & 67,53 & 100,60 \\
\hline & 150 & 27,91 & 72,26 & 0,1024 & 87,81 & 75,72 & 67,76 & 100,17 \\
\hline & 300 & 28,68 & 70,44 & 0,1151 & 88,68 & 77,77 & 70,22 & 99,12 \\
\hline \multirow{3}{*}{75} & 0 & 24,52 & 77,42 & 0,0782 & 85,67 & 71,16 & 62,28 & 101,94 \\
\hline & 150 & 28,55 & 71,41 & 0,1101 & 88,60 & 77,11 & 69,36 & 99,97 \\
\hline & 300 & 30,10 & 69,87 & 0,0744 & 85,07 & 71,76 & 63,69 & 99,97 \\
\hline \multicolumn{9}{|c|}{ Efeitos Principais } \\
\hline 25 & & 28,59 & 69,45 & 0,1339 & 88,45 & 78,34 & 71,24 & 98,04 \\
\hline 50 & & 27,95 & 72,01 & 0,1059 & 88,16 & 76,38 & 68,50 & 99,96 \\
\hline \multirow[t]{4}{*}{75} & & 27,72 & 72,90 & 0,0876 & 86,44 & 73,35 & 65,11 & 100,63 \\
\hline & 0 & 26,44 & 73,75 & 0,1027 & 87,24 & 74,80 & 66,69 & 100,19 \\
\hline & 150 & 28,44 & 70,94 & 0,1134 & 88,21 & 76,95 & 69,33 & 99,38 \\
\hline & 300 & 29,39 & 69,67 & 0,1112 & 87,60 & 76,3 & 68,83 & 99,06 \\
\hline \multicolumn{9}{|c|}{ Dados Médios } \\
\hline \multirow{2}{*}{\multicolumn{2}{|c|}{$\begin{array}{l}\text { Média } \\
\mathrm{CV}\end{array}$}} & 28,09 & 71,45 & 0,1091 & 87,68 & 76,02 & 68,28 & 99,54 \\
\hline & & 8,56 & 5,66 & 31,29 & 2,42 & 5,26 & 6,97 & 1,98 \\
\hline \multicolumn{9}{|c|}{ Probabilidades Estatísticas } \\
\hline \multicolumn{9}{|c|}{ Concentrado } \\
\hline \multicolumn{2}{|c|}{ Linear (L) } & NS & NS & 0,0071 & NS & 0,0102 & 0,0079 & 0,0074 \\
\hline \multicolumn{2}{|c|}{ Desvio (D) } & NS & NS & NS & NS & NS & NS & NS \\
\hline \multicolumn{9}{|c|}{ Monensina } \\
\hline \multicolumn{2}{|c|}{ Linear (L) } & 0,0090 & 0,0300 & NS & NS & NS & NS & NS \\
\hline \multicolumn{2}{|c|}{ Desvio (D) } & NS & NS & NS & NS & NS & NS & NS \\
\hline \multicolumn{9}{|c|}{ Interação } \\
\hline \multicolumn{2}{|c|}{$\operatorname{Con}_{\mathrm{L}} \mathrm{Xmon}_{\mathrm{L}}$} & NS & NS & NS & NS & NS & NS & NS \\
\hline \multicolumn{2}{|c|}{$\operatorname{Con}_{L} \mathrm{Xmon}_{\mathrm{D}}$} & NS & NS & NS & NS & NS & NS & NS \\
\hline \multicolumn{2}{|c|}{$\operatorname{Con}_{\mathrm{D}} \mathrm{Xmon}_{\mathrm{L}}$} & NS & NS & NS & NS & NS & NS & NS \\
\hline \multicolumn{2}{|c|}{ Con $_{\mathrm{D}} \mathrm{Xmon}_{\mathrm{D}}$} & NS & NS & NS & NS & NS & NS & NS \\
\hline
\end{tabular}

${ }^{1} a, b$ e $c$ referem-se aos paràmetros de Ørskov \& McDonald (1979), De = degradabilidade efetiva para taxas de passagem iguais a $0,02,0,05$ e 0,08 e $\mathrm{Dp}=$ degradabilidade potencial. 


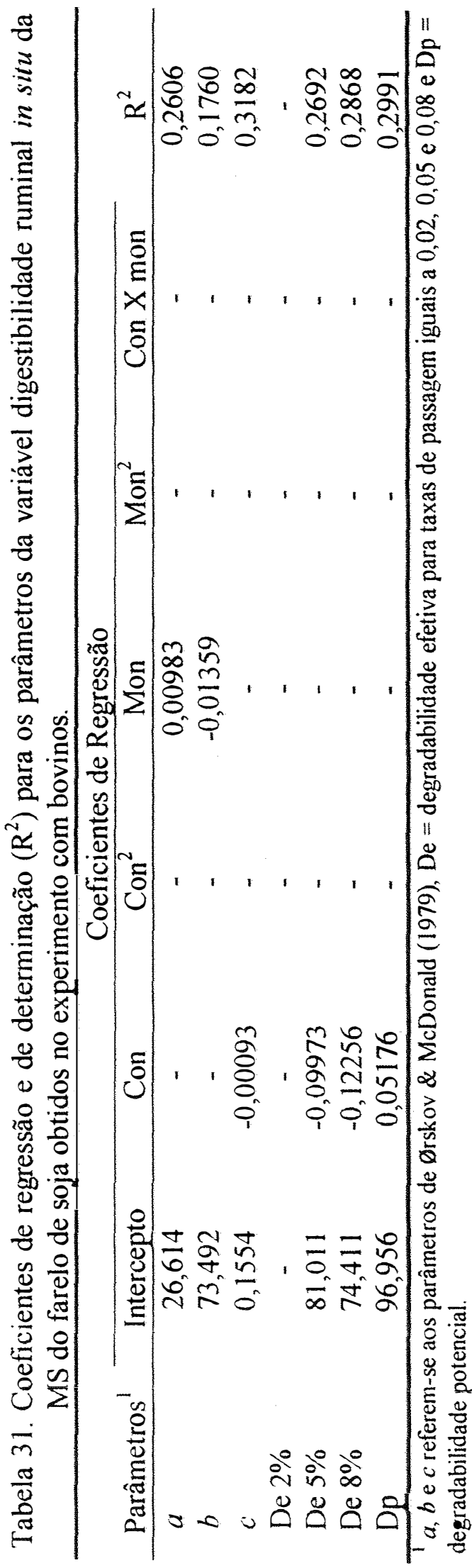


Tabela 32. Efeitos da proporção de concentrados (Con) e dose de monensina (Mon) sobre a digestibilidade ruminal in situ da PB do farelo de soja, coeficientes de variação $(\mathrm{CV})$ e probabilidades estatísticas no experimento com bovinos.

\begin{tabular}{|c|c|c|c|c|c|c|c|c|}
\hline \multicolumn{2}{|c|}{ Tratamentos } & \multicolumn{7}{|c|}{ Parâmetros ${ }^{1}$} \\
\hline Con & Mon & $a$ & $b$ & $c$ & De $2 \%$ & De $5 \%$ & De $8 \%$ & $\mathrm{Dp}$ \\
\hline \multicolumn{9}{|c|}{ Interaçōes } \\
\hline \multirow{3}{*}{25} & 0 & 8,62 & 91,90 & 0,1384 & 88,15 & 74,96 & 65,62 & 100,52 \\
\hline & 150 & 10,50 & 90,89 & 0,1388 & 88,89 & 75,83 & 66,67 & 101,39 \\
\hline & 300 & 11,97 & 88,08 & 0,1561 & 88,94 & 77,05 & 68,52 & 100,04 \\
\hline \multirow{3}{*}{50} & 0 & 7,52 & 94,90 & 0,1054 & 86,41 & 70,69 & 60,30 & 102,43 \\
\hline & 150 & 8,76 & 93,89 & 0,1032 & 85,93 & 70,01 & 59,70 & 102,65 \\
\hline & 300 & 10,48 & 89,55 & 0,1251 & 87,63 & 74,39 & 65,04 & 100,04 \\
\hline \multirow{3}{*}{75} & 0 & 2,62 & 102,94 & 0,0755 & 83,29 & 63,73 & 51,87 & 105,55 \\
\hline & 150 & 8,98 & 92,47 & 0,1121 & 86,86 & 72,08 & 62,09 & 101,46 \\
\hline & 300 & 10,85 & 95,42 & 0,0674 & 83,77 & 64,90 & 53,86 & 106,27 \\
\hline \multicolumn{9}{|c|}{ Efeitos Principais } \\
\hline 25 & & 10,36 & 90,29 & 0,1414 & 88,66 & 75,95 & 66,94 & 100,65 \\
\hline 50 & & 8,92 & 92,78 & 0,1112 & 86,66 & 71,70 & 61,68 & 101,71 \\
\hline \multirow[t]{4}{*}{75} & & 7,48 & 96,94 & 0,0850 & 84,64 & 66,90 & 55,94 & 104,43 \\
\hline & 0 & 6,25 & 96,58 & 0,1064 & 85,95 & 69,79 & 59,27 & 102,83 \\
\hline & 150 & 9,41 & 92,42 & 0,1180 & 87,23 & 72,64 & 62,82 & 101,83 \\
\hline & 300 & 11,10 & 91,02 & 0,1162 & 86,78 & 72,11 & 62,47 & 102,12 \\
\hline \multicolumn{9}{|c|}{ Dados Médios } \\
\hline \multirow{2}{*}{\multicolumn{2}{|c|}{$\begin{array}{l}\text { Média } \\
\text { CV }\end{array}$}} & 8,92 & 93,34 & 0,1136 & 86,65 & 71,51 & 61,52 & 102,26 \\
\hline & & 43,24 & 6,24 & 38,39 & 3,10 & 8,67 & 12,35 & 3,02 \\
\hline \multicolumn{9}{|c|}{ Probabilidades Estatísticas } \\
\hline \multicolumn{9}{|c|}{ Concentrado } \\
\hline \multicolumn{2}{|c|}{ Linear (L) } & NS & 0,0119 & 0,0060 & 0,0010 & 0,0016 & 0,0018 & 0,0103 \\
\hline Des & (D) & NS & NS & NS & NS & NS & NS & NS \\
\hline \multicolumn{9}{|c|}{ Monensina } \\
\hline \multicolumn{2}{|c|}{ Linear (L) } & 0,0075 & 0,0305 & NS & NS & NS & NS & NS \\
\hline \multicolumn{2}{|c|}{ Desvio (D) } & NS & NS & NS & NS & NS & NS & NS \\
\hline \multicolumn{9}{|c|}{ Interação } \\
\hline \multicolumn{2}{|c|}{$\operatorname{Con}_{\mathrm{L}} \mathrm{Xmon}_{\mathrm{L}}$} & NS & NS & NS & NS & NS & NS & NS \\
\hline \multicolumn{2}{|c|}{$\operatorname{Con}_{L} \mathrm{Xmon}_{\mathrm{D}}$} & NS & NS & NS & NS & NS & NS & NS \\
\hline \multicolumn{2}{|c|}{$\operatorname{Con}_{\mathrm{D}} \mathrm{Xmon}$ L. } & NS & NS & NS & NS & NS & NS & NS \\
\hline \multicolumn{2}{|c|}{ Con $_{D} X_{\text {mon }}$} & NS & NS & NS & NS & NS & NS & NS \\
\hline
\end{tabular}

$a, b$ e $c$ referem-se aos parâmetros de Ørskov \& McDonald (1979), De = degradabilidade efetiva para taxas de passagem iguais a $0,02,0,05$ e 0,08 e $\mathrm{Dp}=$ degradabilidade potencial. 


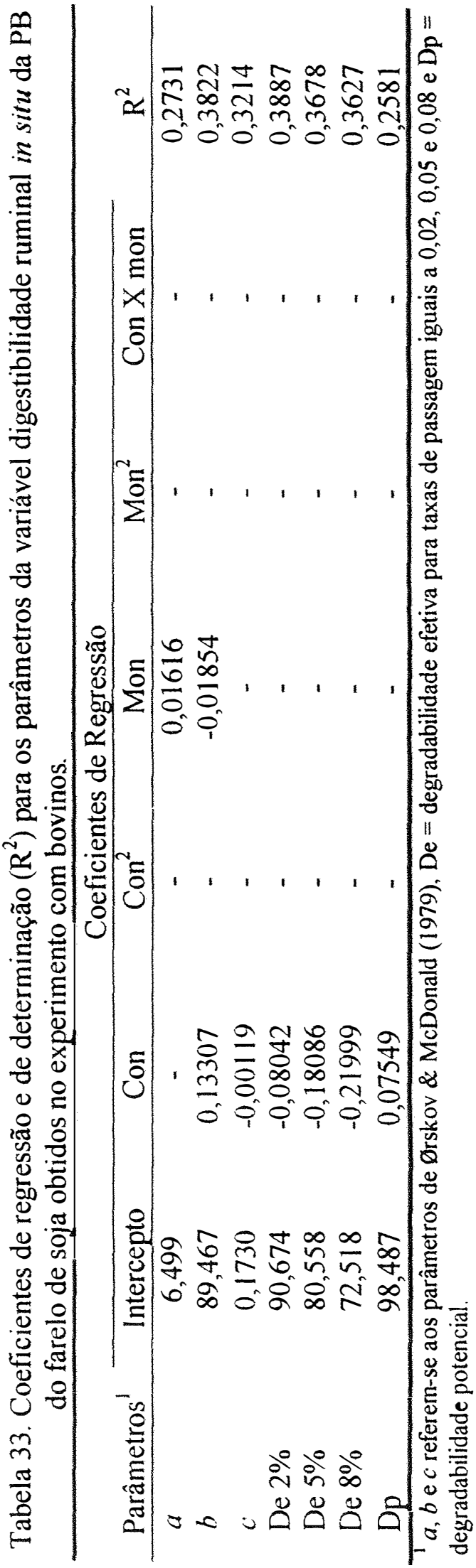




\subsection{Digestibilidade ruminal in situ dos grãos de milho}

Os efeitos da dose de monensina e da proporção de concentrados na ração sobre os parâmetros da digestibilidade ruminal in situ da MS dos grãos de milho moídos, obtidos no experimento com bovinos, encontram-se na Tabela 34.

A proporção de concentrados na dieta e a dosagem de monensina interagiram para a constante $\boldsymbol{a}$ (fração rapidamente degradável estimada a partir da equação de Ørskov \& McDonald, 1979) da MS dos grãos de milho. Enquanto que a monensina diminuiu linearmente esta constante, o aumento da proporção de concentrados apresentou maiores resultados com dietas mistas. Interação também foi observada para a constante $b$ (fração potencialmente degradável), porém com resposta curvilinear para ambos os fatores. O cálculo do ponto estacionário (possível ser obtido neste caso devido à natureza curvilinear para ambos os fatores) demonstrou que maiores valores da fração potencialmente degradável da MS do milho seriam obtidos com 20,1\% de concentrados na dieta e $121,7 \mathrm{mg}$ de monensina/animal/dia. Para a taxa de degradação (constante $c$ ), a interação foi do tipo linear para a dose de monensina e curvilinear para o aumento de concentrados na dieta. Neste caso, a monensina aumentou a taxa de degradação em 0,006 a 0,019 unidades $(9,3 \%$ a $31,8 \%)$ nas dietas predominantemente volumosas e 0,011 a 0,030 unidades $(19,1 \%$ a $52,9 \%)$ nas predominantemente concentradas, com as maiores respostas observadas para doses maiores do produto. Pequeno efeito do produto foi observado em dietas mistas.

Efeito semelhante foi observado para as degradabilidades efetivas quando calculadas para taxas de passagens ruminais de $5 \% / \mathrm{h}$ e $8 \% / \mathrm{h}$, mas não para $2 \% / \mathrm{h}$ (Figura 13). Neste caso, as doses mais elevadas de monensina aumentaram a degradabilidade efetiva da MS em até 3,3 a 3,6 unidades percentuais (5,6\% a 7,3\%) em dietas predominantemente volumosas e em até 5,5 a 6,4 unidades percentuais $(9,3 \%$ a $13,4 \%)$ nas predominantemente concentradas. Somente a monensina diminuiu linearmente a degradabilidade potencial do milho $(a)$. 
Os dados obtidos no presente experimento discordam daqueles obtidos por Funk et al. (1986), com lasalocida, e Haimoud et al. (1995) e Haimoud et al. (1996), com monensina, os quais relataram que os ionóforos diminuíram a digestibilidade ruminal do amido, sem contudo, causar alteração da digestibilidade total deste componente. O primeiro autor postulou que a mudança do sítio de digestão do amido poderia explicar, em parte, a melhora no desempenho dos animais, já que o amido seria metabolizado mais eficientemente quando digerido no trato digestivo posterior, conceito esse que vem sendo contestado por trabalhos recentes. Entretanto, outros autores não observaram mudança no sítio do trato gastro-intestinal onde a digestão do amido se processava ou na extensão da digestão deste componente quando novilhos receberam monensina (Suber \& Bowman, 1998), monensina ou lasalocida (Darden et al., 1985), lasalocida ou monensina mais tilosina (Zinn, 1987), lasalocida, monensina mais tilosina ou lasalocida alternada de monensina mais tilosina diariamente (Morris et al., 1990) ou quando vacas recém-paridas receberam lasalocida na dieta (Knowlton et al., 1996a).

Wedegaertner \& Johnson (1983) também não observaram efeito da monensina sobre a digestibilidade total do amido em novilhos alimentados com dieta predominantemente concentrada, nem tão pouco Zinn \& Borques (1993) em bovinos alimentados com dieta rica em energia, através da suplementação com gordura.

Rogers \& Davis (1982) mostraram que a monensina tendeu em aumentar a digestibilidade total do amido em $2,7 \%$, quando administrada a novilhos alimentados com dieta mista ( $50 \%$ de volumoso), explicando tal achado pela provável diminuição no consumo de alimentos, com conseqüente aumento no tempo de retenção da MS no rúmen. Suber \& Bowman (1998) observaram ainda que os efeitos da monensina sobre a digestibilidade in vitro de grãos de cevada variava conforme a variedade estudada. Observaram os autores que uma variedade tinha a digestibilidade in vitro aumentada, enquanto que outra tinha a digestibilidade diminuída com a adição de monensina ao meio, embora o milho não apresentasse qualquer resposta. Entretanto, estes autores não conseguiram reproduzir os mesmos resultados quando utilizaram a técnica dos sacos de náilon in situ. 
Embora o aumento na digestibilidade ruminal do amido causado pela monensina neste experimento não encontre apoio na literatura revisada, este efeito poderia explicar, em parte, a afirmação de Chalupa (1977) de que os ionóforos diminuem as concentrações ruminais de nitrogênio amoniacal, fato confirmado no presente experimento, também por estimular o crescimento microbiano e provavelmente a degradação das fontes energéticas prontamente disponiveis no rúmen. 
Tabela 34. Efeitos da proporção de concentrados (Con) e dose de monensina (Mon) sobre a digestibilidade ruminal in situ da MS dos grãos de milho moido, coeficientes de variação $(\mathrm{CV})$ e probabilidades estatísticas no experimento com bovinos.

\begin{tabular}{|c|c|c|c|c|c|c|c|c|}
\hline \multicolumn{2}{|c|}{ Tratamentos } & \multicolumn{7}{|c|}{ Parâmetros } \\
\hline Con & Mon & $a$ & $b$ & $c$ & De $2 \%$ & De $5 \%$ & De $8 \%$ & $D p$ \\
\hline \multicolumn{9}{|c|}{ Interaçōes } \\
\hline \multirow{3}{*}{25} & 0 & 9,52 & 93,88 & 0,0590 & 79,05 & 59,74 & 48,88 & 103,40 \\
\hline & 150 & 6,48 & 98,24 & 0,0645 & 81,30 & 61,65 & 50,19 & 104,72 \\
\hline & 300 & 7,46 & 91,90 & 0,0778 & 80,26 & 63,06 & 52,46 & 99,36 \\
\hline \multirow{3}{*}{50} & 0 & 7,50 & 96,34 & 0,0621 & 80,00 & 60,50 & 49,31 & 103,85 \\
\hline & 150 & 9,56 & 90,87 & 0,0623 & 78,27 & 59,89 & 49,28 & 100,43 \\
\hline & 300 & 9,72 & 93,57 & 0,0576 & 79,17 & 59,81 & 48,89 & 103,28 \\
\hline \multirow{3}{*}{75} & 0 & 9,41 & 94,12 & 0,0565 & 78,47 & 58,90 & 48,02 & 103,53 \\
\hline & 150 & 8,47 & 92,82 & 0,0673 & 79,77 & 61,46 & 50,66 & 101,30 \\
\hline & 300 & 9,50 & 87,00 & 0,0864 & 79,95 & 64,37 & 54,46 & 96,50 \\
\hline \multicolumn{9}{|c|}{ Efeitos Principais } \\
\hline 25 & & 7,82 & 94,67 & 0,0671 & 80,20 & 61,48 & 50,51 & 102,49 \\
\hline 50 & & 8,93 & 93,59 & 0,0606 & 79,15 & 60,07 & 49,16 & 102,52 \\
\hline \multirow[t]{4}{*}{75} & & 9,13 & 91,32 & 0,0701 & 79,40 & 61,58 & 51,05 & 100,44 \\
\hline & 0 & 8,81 & 94,78 & 0,0592 & 79,17 & 59,71 & 48,73 & 103,59 \\
\hline & 150 & 8,17 & 93,98 & 0,0647 & 79,78 & 61,00 & 50,04 & 102,15 \\
\hline & 300 & 8,89 & 90,82 & 0,0740 & 79,80 & 62,41 & 51,94 & 99,71 \\
\hline \multicolumn{9}{|c|}{ Dados Médios } \\
\hline \multirow{2}{*}{\multicolumn{2}{|c|}{$\begin{array}{l}\text { Média } \\
\text { CV }\end{array}$}} & 8,62 & 93,19 & 0,0660 & 79,58 & 61,04 & 50,24 & 101,82 \\
\hline & & 18,42 & 4,23 & 20,02 & 2,08 & 4,32 & 5,75 & 3,57 \\
\hline \multicolumn{9}{|c|}{ Probabilidades Estatísticas } \\
\hline \multicolumn{9}{|c|}{ Concentrado } \\
\hline \multicolumn{2}{|c|}{ Linear $(\mathrm{L})$} & NS & 0,0232 & NS & NS & NS & NS & NS \\
\hline \multicolumn{2}{|c|}{ Desvio (D) } & NS & NS & NS & NS & NS & NS & NS \\
\hline \multicolumn{9}{|c|}{ Monensina } \\
\hline \multicolumn{2}{|c|}{ Linear (L) } & NS & 0,0092 & 0,0067 & NS & 0,0146 & 0,0063 & 0,0168 \\
\hline Des & (D) & NS & NS & NS & NS & NS & NS & NS \\
\hline \multicolumn{9}{|c|}{ Interação } \\
\hline \multicolumn{2}{|c|}{$\operatorname{Con}_{L} X_{m o n}$} & NS & NS & NS & NS & NS & NS & NS \\
\hline \multicolumn{2}{|c|}{$\operatorname{Con}_{\mathrm{L}} \mathrm{Xmon}_{\mathrm{D}}$} & NS & NS & NS & NS & NS & NS & NS \\
\hline \multicolumn{2}{|c|}{$\mathrm{Con}_{\mathrm{D}} \mathrm{Xmon}_{\mathrm{L}}$} & 0,0349 & NS & 0,0111 & NS & 0,0271 & 0,0231 & NS \\
\hline \multicolumn{2}{|c|}{$\operatorname{Con}_{\mathrm{D}} \mathrm{Xmon}_{\mathrm{D}}$} & NS & 0,0055 & NS & NS & NS & NS & NS \\
\hline
\end{tabular}

${ }_{a} a, b$ e $c$ referem-se aos parâmetros de Ørskov \& McDonald (1979), De = degradabilidade efetiva para taxas de passagem iguais a $0,02,0,05$ e 0,08 e $\mathrm{Dp}=$ degradabilidade potencial. 


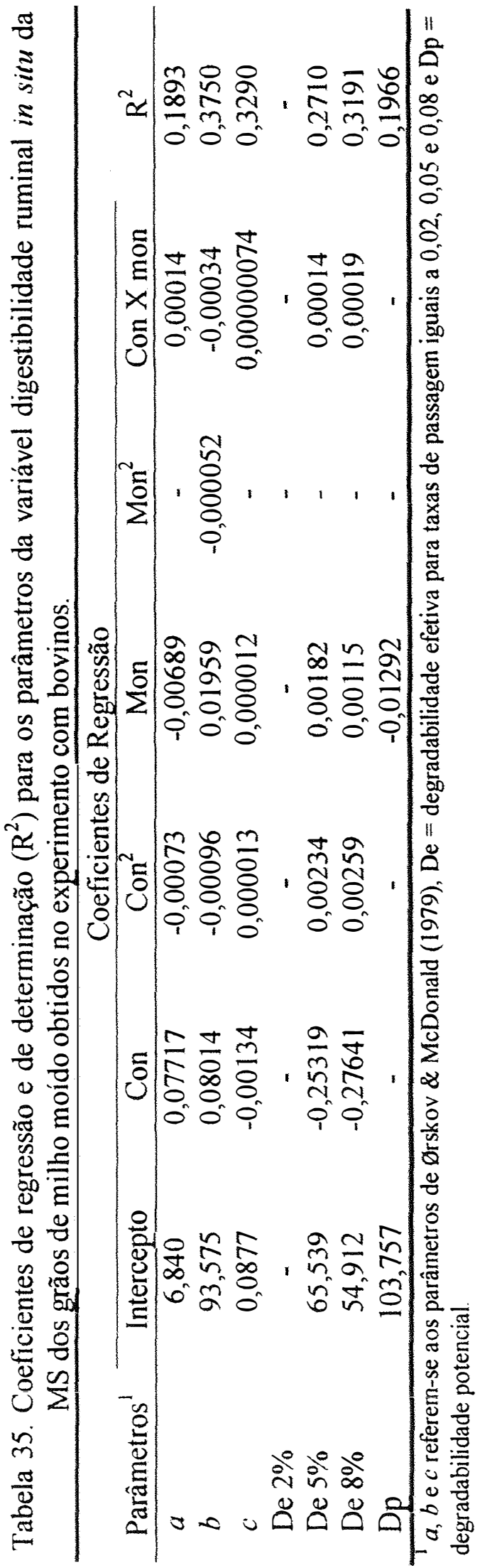



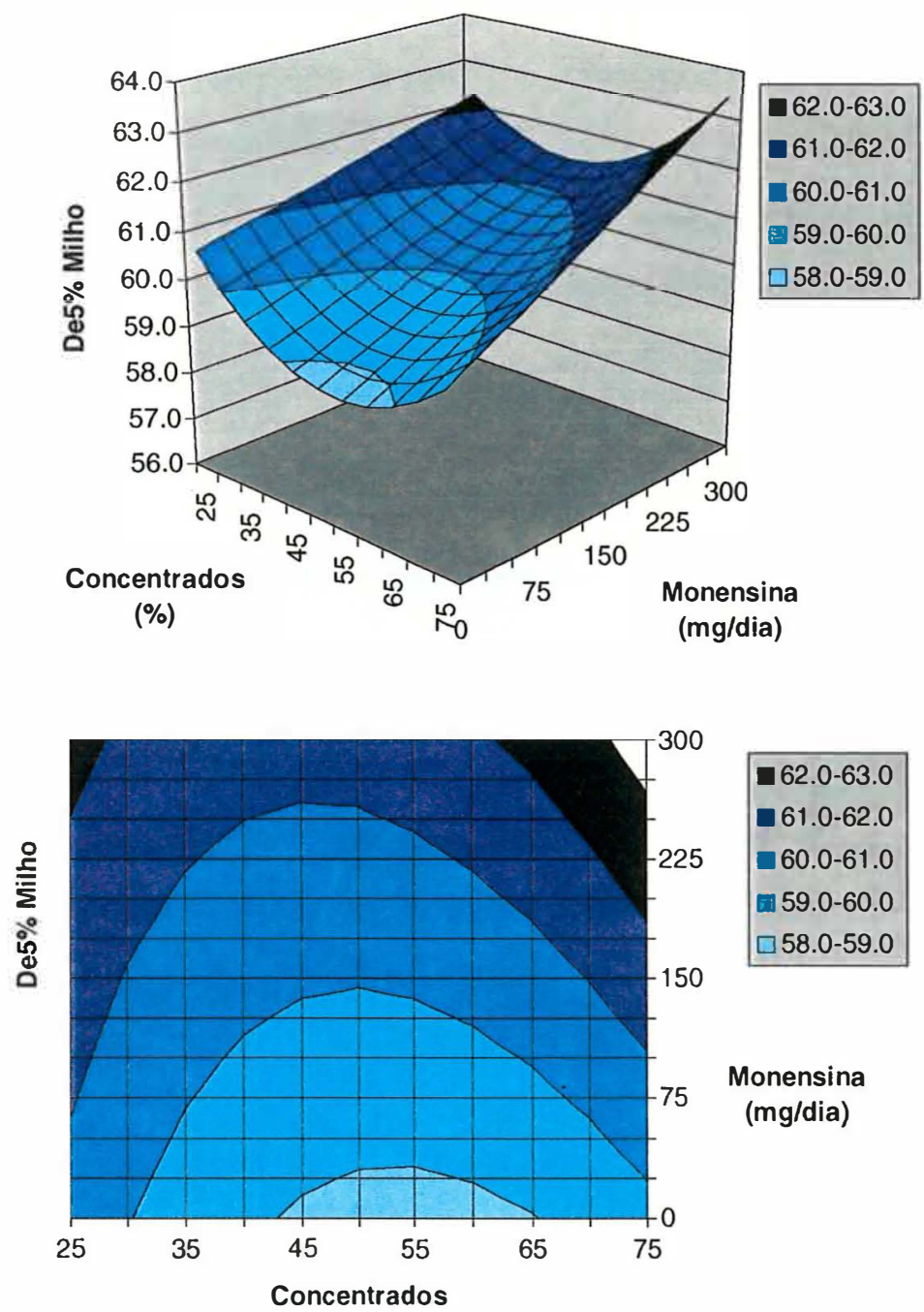

(\%)

Figura 13 - Efeitos da proporção de concentrados (\% da dieta) e dose de monensina (mg/animal/dia) sobre a degradabilidade efetiva da MS dos grãos de milho moídos, quando calculada para taxa de passagem de 0,05 (De 5\%), obtidos no experimento com bovinos. 


\subsection{Digestibilidade aparente in vivo}

As Tabelas 36 e 40 apresentam respectivamente os valores de digestibilidade aparente da MS da dieta e suas frações obtidos nos experimentos com bovinos e ovinos e as Tabelas 38 e 42 apresentam os mesmos valores quando corrigidos para o consumo diário de matéria seca.

\subsubsection{Digestibilidade aparente da matéria seca}

A adição de monensina à dieta dos bovinos aumentou linearmente a digestibilidade aparente da MS, quando este valor foi corrigido para o consumo diário de MS, em 5,9 a 11,4 unidades percentuais (10,5\% a 20,4\%) para doses de 150 e $300 \mathrm{mg}$ de monensina/animal/dia, respectivamente, independentemente da proporção de concentrados adicionada à dieta (Figura 14). Entretanto, nenhum efeito deste produto sobre a digestibilidade da MS foi observado no experimento com ovinos, fossem os dados corrigidos ou não para o consumo.

Os resultados com bovinos parece compatível com vários trabalhos encontrados na literatura que têm demonstrado aumento na digestibilidade da MS e/ou matéria orgânica com o uso de ionóforos (Horton et al., 1980; Wedegaertner \& Johnson, 1983; Tanner et al., 1984; Faulkner et al., 1985; Beede et al., 1986b; Funk et al., 1986; Pomar et al., 1989; Branine \& Galyean, 1990; Lee et al., 1992; Richter \& Flachowski, 1990; Araujo-Febres \& Fernández, 1991; Duff et al., 1995; Salles, 1997; Peixoto Jr., 1998), embora outros não tenham demonstrado que a monensina (Benz \& Johnson, 1982; Rogers \& Davis, 1982; Zinn \& Borques, 1993; Haimoud et al., 1995; Haimoud et al., 1996; Suber \& Bowman, 1998), lasalocida (Paterson et al., 1983; Dye et al., 1988; Bem, 1991; Bogaërt et al., 1991; Knowlton et al., 1996a; Wessels et al., 1996), monensina ou lasalocida (Darden et al., 1985), lasalocida ou monensina mais tilosina (Zinn, 1987), lasalocida, monensina mais tilosina ou lasalocida alternada de monensina 
mais tilosina diariamente (Morris et al., 1990) tenham alterado a digestibilidade da matéria seca ou orgânica quando administrada à dieta dos ruminantes. Poos et al. (1979) afirmaram ainda que a monensina diminuía a digestibilidade da MS quando administrada em animais não adaptados, mas que esse efeito diminuía com o aumento do período de adaptação.

O aumento da digestão dos alimentos obtido com o emprego de ionóforos tem sido freqüentemente explicado pelo aumento do tempo de retenção da MS no rúmen (Ellis et al., 1983) decorrente do menor consumo voluntário (Rogers \& Davis, 1982). Entretanto, Branine \& Galyean (1990) explicaram tal achado pelo aumento da degradação da parede celular, decorrente do aumento no $\mathrm{pH}$ ruminal, e não pela diminuição da taxa de passagem de MS pelo pró-ventrículo. O efeito da monensina observado no presente experimento com bovinos após a correção para o consumo parece discordar da afirmação de Ellis et al. (1983) de que a melhora da digestibilidade seria decorrente da diminuição do consumo, podendo outros fatores, como aquele apontado por Branine \& Galyean (1990), estarem envolvidos.

Embora seja aceito que os ionóforos causem pequena a moderada melhora na digestibilidade dos alimentos (Schelling, 1984), estas condições não estão definidas até o presente momento, podendo sofrer interferência de fatores como consumo de alimentos, enchimento ruminal, taxa de passagem ou outros. Enquanto que o experimento de Pomar et al. (1989) demonstrou que a monensina aumentou levemente a digestibilidade da MS somente nas rações ricas em volumosos, o experimento realizado por McCann et al. (1990) demonstrou que este ionóforo apresentou tendência em aumentar a digestibilidade da matéria orgânica a medida em que a proporção de volumosos era diminuída, fato esse que foi parcialmente confirmado por Araujo-Febres \& Fernández (1991). O presente experimento demonstrou efeito da monensina sobre este parâmetro independentemente do nível de fibra utilizado, enquanto que Thornton \& Owens (1981) e Zinn et al. (1994) não demonstraram qualquer efeito da monensina sobre a digestibilidade da matéria seca e matéria orgânica, respectivamente, independentemente da característica da dieta. 


\subsubsection{Digestibilidade aparente da fibra}

O aumento da proporção de concentrados à dieta dos bovinos diminuiu curvilinearmente a digestibilidade aparente da fibra bruta, fibra em detergente neutro e fibra em detergente ácido. As quedas foram de até 5,36 unidades percentuais $(8,5 \%)$ para a dieta mista e variaram de 34,7 a 40,1 unidades percentuais $(57,7 \%$ a $62,7 \%)$ para a dieta predominantemente concentrada, quando comparadas com aquela predominantemente volumosa, considerando as três metodologias utilizadas para avaliar a fibra. Quando os presentes dados foram corrigidos para o consumo, o efeito obtido com o uso de concentrados passou a ser estatisticamente do tipo linear, e as quedas foram de até 11,9 unidades percentuais $(17,8 \%)$ para a dieta mista e de até 43,9 unidades percentuais $(64,2 \%)$ para a dieta predominantemente concentrada, quando comparadas com a predominantemente volumosa. Quando comparados aos bovinos, dados de queda da digestibilidade da fibra por ação do uso de concentrados foram comparativamente menores no experimento com carneiros, chegando a 5,3 unidades percentuais $(8,6 \%)$ para a dieta mista e 16,8 unidades percentuais $(27,1 \%)$ para a dieta predominantemente concentrada, quando comparadas à predominantemente volumosa. As respostas foram sempre do tipo linear, independentemente da correção ou não para o consumo de MS.

Já o ionóforo aumentou linearmente a digestibilidade aparente da FDA no experimento com bovinos (Figura 17), quando os dados foram corrigidos para 0 consumo de MS, e este efeito foi independente do nível de fibra na dieta, embora doses mais altas deste produto tenham aumentado numericamente a digestibilidade aparente da FB em até 21,2 unidades percentuais $(203,7 \%)$ na dieta predominantemente concentrada, 13,3 unidades percentuais $(27,4 \%)$ na dieta mista e apenas 6,9 unidades percentuais $(12,2 \%)$ na dieta predominantemente volumosa. Dados numericamente, mas não estatisticamente, semelhantes foram obtidos para a digestibilidade aparente da FDA 
não corrigida para o consumo e digestibilidade da FB e FDN, corrigidas ou não para o consumo.

O experimento com carneiros apresentou interação entre a proporção de concentrados na ração e a presença da monensina na dieta, quando os dados foram corrigidos para o consumo, para a variável digestibilidade aparente da fibra bruta (Figura 19). A interação não apresentou resposta linear, de forma que a presença de ionóforos aumentou a digestibilidade desta fração em 9,1 unidades percentuais $(21,4 \%)$ na dieta predominantemente concentrada.

Resultados aparentemente semelhantes foram observados por McCann et al. (1990) e por Araujo-Febres \& Fernández (1991) ao demonstrarem que a digestibilidade aparente da FDN e da FB aumentavam, respectivamente, com o uso de ionóforos, e que esse aumento era maior a medida em que a proporção de concentrados era aumentada.

Já Pomar et al. (1989) observaram que a monensina diminuía a digestibilidade da FDN e FDA em dietas predominantemente concentradas, mas aumentava a digestibilidade destas frações fibrosas em dietas predominantemente volumosas, enquanto que Thornton \& Owens (1981) e Zinn et al. (1994) não demonstraram efeitos dos ionóforos sobre a digestibilidade da fibra independentemente do nível de fibra da dieta.

Vários outros trabalhos não demonstraram efeitos dos ionóforos em alterar digestibilidade da FDN (Rogers \& Davis, 1982; Paterson et al., 1983; Zinn, 1987; Knowlton et al., 1996a), FDA (Zinn \& Borques, 1993), FB (Peixoto Jr., 1998), FDN e FDA (Benz \& Johnson, 1982; Beede et al., 1986b; Wessels et al., 1996), FB, FDN, FDA (Bem, 1991) e FDN, FDA, celulose e hemicelulose (Dye et al., 1988), embora outros tenham observado efeitos positivos para a digestibilidade aparente da FB (Horton et al., 1980; Richter \& Flachowski, 1990), FDN (Wedegaertner \& Johnson, 1983; Tanner et al., 1984; Faulkner et al., 1985; Galloway et al., 1993) e FB e FDN (Lipiec et al., 1991; Salles, 1997). Poos et al. (1979) observaram ainda, diminuição da digestibilidade da FDA em animais não adaptados à monensina, mas não nos adaptados. 
Apesar dos dados de digestibilidade ruminal in situ terem demonstrado interação entre dose do produto e proporção de concentrados na dieta, de forma que a degradação da fibra no rúmen fosse diminuída ao se associar dietas com baixo nível em fibra e altas doses do produto, este efeito desapareceu ao se avaliar a digestão da fibra por todo o trato gastro-intestinal. Inclusive, foram observados efeitos inversos, já que foram nestas mesmas condições (baixo nível de fibra na dieta) que o produto apresentou as melhores respostas para a digestibilidade aparente da fibra. Resposta tão curiosa tem sido comumente explicada na literatura como sendo decorrente do aumento do tempo de retenção da MS no rúmen (Ellis et al., 1983) decorrente do menor consumo voluntário de alimentos (Rogers \& Davis, 1982). Tal explicação seria completamente rejeitada no presente experimento, de modo que a melhor possibilidade para explicar esta resposta seria a melhora das condições de $\mathrm{pH}$ ruminal.

Uma outra possibilidade seria o estímulo à ruminação. Tal efeito aumentaria a digestão total da fibra no trato digestivo, mas não a digestão ruminal in situ, já que o feno aqui testado se encontrava dentro dos saquinhos e, portanto, indisponivel à ruminação. Knowlton et al. (1996b), estudando os efeitos da lasalocida sobre comportamento alimentar de vacas leiteiras recém-paridas, observaram que esse produto era realmente capaz de aumentar o tempo de ruminação diário (minutos/dia) em $15,8 \%$ a $19,0 \%$, sem, contudo, terem demonstrado aumento da digestibilidade total da FDN (Knowlton et al., 1996a).

\subsubsection{Digestibilidade aparente da proteína bruta}

Enquanto que o aumento da proporção de concentrados na dieta dos bovinos diminuiu linearmente a digestibilidade aparente da proteína bruta em 3,6 a 13,9 unidades percentuais $(5,0 \%$ a $19,7 \%)$, em relação à dieta mais volumosa, a adição de monensina aumentou, também linearmente, a digestibilidade aparente desta fração em 7,1 a 11,6 unidades percentuais $(12,1 \%$ a $19,8 \%)$, em relação às dietas controle (sem monensina), não sendo encontrada interação entre os dois fatores estudados no presente 
experimento (Figura 15). Já no experimento com ovinos o aumento da proporção de concentrados na dieta aumentou linearmente a digestibilidade aparente da proteína bruta em 3,3 a 4,1 unidades percentuais $(4,8 \%$ a $6,1 \%)$, em relação à dieta mais volumosa, quando os dados foram corrigidos para o consumo de MS. Mais uma vez, nesses animais, a monensina também aumentou a digestibilidade da proteína bruta em 3,7 e 3,6 unidades percentuais $(5,4 \%$ e $5,3 \%)$ quando os dados não foram ou foram corrigidos, respectivamente, para o consumo de MS, independentemente do nível de fibra na dieta (Figura 18).

Os dados encontrados no presente trabalho concordam com muitos outros que observaram aumento da digestibilidade aparente da proteína bruta com o emprego de ionóforos na dieta (Joyner et al., 1979; Horton et al., 1980; Rogers \& Davis, 1982; Paterson et al., 1983; Wedegaertner \& Johnson, 1983; Ricke et al., 1984; Beede et al., 1986b; Zinn, 1987; Dye et al., 1988; Galloway et al., 1993; Salles, 1997). O fato do presente experimento ter demonstrado que a monensina é capaz de aumentar a proteólise ruminal, seja através dos dados de digestibilidade ruminal in situ quando incubada por curtos espaços de tempo, seja através dos dados de digestibilidade in vitro quando foi utilizado inóculo obtido de animais recebendo dosagens intermediárias, faz suspeitar da hipótese de que este produto diminua a proteólise (Dinius et al., 1976; Rodriguez et al., 1986) em conseqüência à inibição do crescimento bacteriano (Hanson \& Klopfenstein, 1979; Poos et al., 1979; Schelling, 1984; Faulkner et al., 1985; Zinn, 1987; Gomez et al., 1991).

Porém, os resultados aqui encontrados não são incompatíveis com o conhecimento de que estes produtos possam diminuir a deaminação (Russell et al., 1988; Chen \& Russell, 1991; Van Kessel \& Russell, 1992), fazendo com que peptídeos e aminoácidos protegidos da deaminação possam ser convertidos em proteína microbiana por cepas resistentes ao ionóforo (Yang \& Russell, 1993).

Efeitos tão pronunciados sobre o metabolismo do nitrogênio, observados no presente e em outros experimentos, faz discordar da hipótese de que os efeitos dos 
ionóforos sobre a digestibilidade da PB possa ser explicada unicamente em decorrência à diminuição no consumo de MS, como sugerido por Rogers \& Davis (1982).

A ausência de interação entre dose de monensina e proporção de concentrados, encontrada no presente experimento, sugere que o efeito da monensina em aumentar a digestibilidade da PB independe do nível de fibra na dieta, embora os dados numéricos do experimento com bovinos demonstrem maior efeito do produto em dietas predominantemente concentradas (11,7-19,0 unidades percentuais ou 25,3-40,9\%) do que em mistas (1,2-6,8 unidades percentuais ou 1,8-10,6\%) ou predominantemente volumosas (8,4-9,0 unidades percentuais ou 13,0-13,9\%). Resultados semelhantes, mas estatisticamente significativos, foram observados Araujo-Febres \& Fernández (1991) e McCann et al. (1990).

Discordando do presente experimento, outros não observaram efeitos dos ionóforos sobre a digestibilidade da PB (Dinius et al., 1976; Darden et al., 1985; Funk et al., 1986; Johnson et al., 1988; Marounek et al., 1990; Pomar et al., 1989; Morris et al., 1990; Zinn \& Borques, 1993; Haimoud et al., 1995; Haimoud et al., 1996; Wessels et al., 1996; Peixoto Jr., 1998; Suber \& Bowman, 1998). Thornton \& Owens (1981) e Zinn et al. (1994) observaram ainda que a ausência de efeitos independia do nível de fibra da dieta.

\subsubsection{Digestibilidade aparente do extrato etéreo}

Embora o presente trabalho não tenha demonstrado efeito da monensina, independente da proporção de concentrados da dieta, sobre a digestibilidade do extrato etéreo, Marounek et al. (1990) relataram aumento significativo da digestibilidade dos lipídios com o uso de monensina em bezerros e Johnson et al. (1988) relataram que a lasalocida aumentou a digestibilidade do extrato etéreo em dietas suplementadas com gordura, explicando tal efeito pelo menor consumo de alimentos resultante da associação da gordura com o ionóforo. Entretanto, o presente experimento apresentou teores de extrato etéreo bastante baixos $(0,9 \%$ a $1,9 \%)$, quando comparados aos 
experimentos anteriormente citados, sendo esta fração constituída possivelmente em sua maioria por compostos de baixa digestibilidade, como cêras e pigmentos. Peixoto Jr. (1998) também não demonstrou efeitos da lasalocida sobre a digestibilidade desta fração quando alimentou novilhas com dietas contendo teores de gordura semelhantes aos aqui estudados.

No experimento com carneiros, observou-se aumento linear na digestibilidade desta fração solúvel em solventes orgânicos entre 11,1 e 13,8 unidades percentuais $(16,8 \%$ e $20,9 \%)$ das dietas mistas e concentradas, respectivamente, em relação à dieta volumosa, provavelmente sendo este efeito decorrente da substituição de compostos indigestíveis formados por cêras e pigmentos contidos no volumoso por triglicerídios e fosfolípides dos alimentos concentrados.

\subsubsection{Nutrientes digestíveis totais (NDT) e digestibilidade aparente da energia bruta e dos extrativos não nitrogenados (ENN)}

A adição de monensina na dieta dos bovinos aumentou linearmente os nutrientes digestíveis totais, quando os dados foram corrigidos para o consumo de MS, mas não nos dados brutos (Figura 16). O aumento do NDT foi da ordem de 5,4 unidades percentuais $(9,6 \%)$ para a menor dose de monensina e 10,5 unidades percentuais $(18,6 \%)$ para a maior dose, quando comparado com a dieta controle (sem monensina), independentemente da proporção de concentrados utilizada.

No experimento com carneiros, foi observado aumento linear do NDT e da digestibilidade aparente da energia bruta e aumento curvilinear da digestibilidade aparente do extrativo não nitrogenado, somente em função do aumento de concentrados na dieta, corrigidos ou não para o consumo, mas não em função da dose de monensina. A falta de efeitos da proporção de concentrados sobre o NDT da dieta, no experimento com bovinos, parece resultar dos efeitos associativos, ou não aditivos, que contribuiriam para que a digestibilidade da fibra fosse diminuída na presença de alta proporção de carboidratos não estruturais, compensando os ganhos. Adicionalmente, dietas com 
maiores teores de fibra diminuiriam o consumo, promovendo maior tempo de retenção do alimento no trato digestivo, e, portanto, maior digestibilidade.

Quanto ao efeito da monensina, os resultados positivos obtidos no presente experimento concordam com aqueles observados por Horton et al. (1980), Wedegaertner \& Johnson (1983), Beede et al. (1986b), Salles (1997) e Castro (1998) para a digestibilidade da energia da dieta, embora Benz \& Johnson (1982), Dye et al. (1988), Bem (1991), Zinn \& Borques (1993) e Peixoto Jr. (1998) não tivessem demonstrado o mesmo. 
Tabela 36. Efeitos da proporção de concentrados (Con) e dose de monensina (Mon) sobre a digestibilidade aparente (em \%) da MS da dieta e suas frações, coeficientes de variação $(\mathrm{CV})$ e probabilidades estatísticas no experimento com bovinos.

\begin{tabular}{|c|c|c|c|c|c|c|c|c|c|}
\hline \multicolumn{2}{|c|}{ Tratamentos } & \multicolumn{8}{|c|}{ Frações } \\
\hline Con & Mon & MS & $\mathrm{PB}$ & FB & ENN & $\mathrm{EE}$ & NDT & FDN & FDA \\
\hline \multicolumn{10}{|c|}{ Interações } \\
\hline \multirow{3}{*}{25} & 0 & 59,74 & 64,67 & 64,85 & 59,61 & 43,55 & 58,50 & 58,97 & 52,02 \\
\hline & 150 & 65,26 & 73,10 & 70,89 & 63,74 & 51,12 & 63,64 & 64,44 & 58,49 \\
\hline & 300 & 67,40 & 73,67 & 72,64 & 65,72 & 51,64 & 65,23 & 66,86 & 61,34 \\
\hline \multirow{3}{*}{50} & 0 & 67,07 & 64,27 & 70,32 & 69,15 & 61,82 & 66,32 & 59,94 & 61,47 \\
\hline & 150 & 64,04 & 65,43 & 62,74 & 66,93 & 54,78 & 63,42 & 53,86 & 54,26 \\
\hline & 300 & 70,71 & 71,08 & 66,41 & 74,72 & 62,17 & 69,83 & 60,39 & 56,73 \\
\hline \multirow{3}{*}{75} & 0 & 44,10 & 46,38 & 16,56 & 51,62 & 48,40 & 46,29 & 14,46 & 9,17 \\
\hline & 150 & 54,26 & 58,10 & 31,81 & 59,81 & 59,63 & 55,84 & 20,28 & 22,70 \\
\hline & 300 & 62,91 & 65,33 & 39,70 & 69,17 & 47,85 & 63,80 & 33,19 & 35,99 \\
\hline \multicolumn{10}{|c|}{ Efeitos Principais } \\
\hline 25 & & 64,14 & 70,48 & 69,46 & 63,02 & 48,77 & 62,66 & 63,42 & 57,35 \\
\hline 50 & & 67,27 & 66,93 & 66,49 & 70,26 & 59,59 & 66,52 & 58,06 & 57,49 \\
\hline \multirow[t]{4}{*}{75} & & 53,76 & 56,60 & 29,36 & 60,20 & 51,96 & 55,31 & 23,66 & 22,62 \\
\hline & 0 & 56,97 & 58,44 & 50,58 & 60,13 & 51,26 & 57,04 & 48,20 & 40,89 \\
\hline & 150 & 61,19 & 65,54 & 55,15 & 63,49 & 55,18 & 60,97 & 46,19 & 45,15 \\
\hline & 300 & 67,01 & 70,03 & 59,58 & 69,87 & 53,88 & 66,29 & 53,48 & 51,42 \\
\hline \multicolumn{10}{|c|}{ Dados Médios } \\
\hline \multirow{2}{*}{\multicolumn{2}{|c|}{$\begin{array}{l}\text { Média } \\
\text { CV }\end{array}$}} & 61,72 & 64,67 & 55,10 & 64,50 & 53,44 & 61,43 & 49,33 & 45,82 \\
\hline & & 18,95 & 15,96 & 42,76 & 17,52 & 22,59 & 17,03 & 42,19 & 47,69 \\
\hline \multicolumn{10}{|c|}{ Probabilidades Estatisticas } \\
\hline \multicolumn{10}{|c|}{ Concentrado } \\
\hline \multicolumn{2}{|c|}{ Linear (L) } & NS & 0,0018 & 0,0001 & NS & NS & NS & 0,0001 & 0,0001 \\
\hline \multicolumn{2}{|c|}{ Desvio (D) } & NS & NS & 0,0195 & NS & NS & NS & 0,0086 & 0,0102 \\
\hline \multicolumn{10}{|c|}{ Monensina } \\
\hline \multicolumn{2}{|c|}{ Linear (L) } & NS & 0,0066 & NS & NS & NS & NS & NS & NS \\
\hline \multicolumn{2}{|c|}{ Desvio (D) } & NS & NS & NS & NS & NS & NS & NS & NS \\
\hline \multicolumn{10}{|c|}{ Interação } \\
\hline Con & $\operatorname{mon}_{\mathrm{L}}$ & NS & NS & NS & NS & NS & NS & NS & NS \\
\hline Con & $\operatorname{mon}_{\mathrm{D}}$ & NS & NS & NS & NS & NS & NS & NS & NS \\
\hline Con & $\operatorname{mon}_{\mathrm{L}}$ & NS & NS & NS & NS & NS & NS & NS & NS \\
\hline Con & $\operatorname{mon}_{\mathrm{D}}$ & NS & NS & NS & NS & NS & NS & NS & NS \\
\hline
\end{tabular}




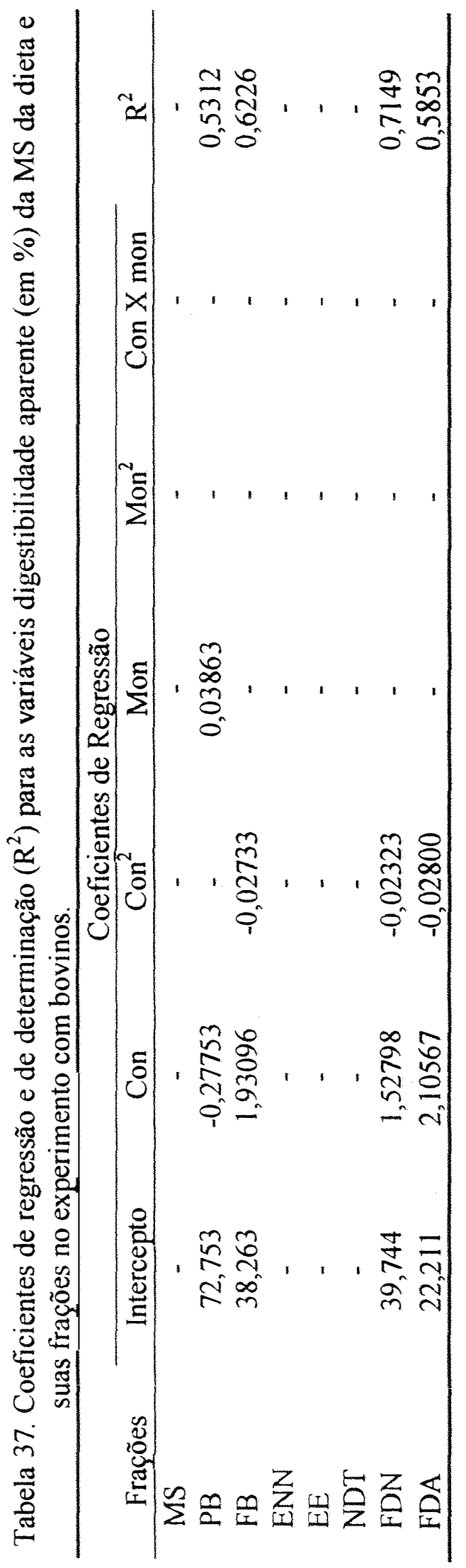


Tabela 38. Efeitos da proporção de concentrados (Con) e dose de monensina (Mon) sobre a digestibilidade aparente (em \%) da MS da dieta e suas frações, quando corrigidas para o consumo diário de matéria seca $(\mathrm{kg} / \mathrm{dia})$, coeficientes de variação $(\mathrm{CV})$ e probabilidades estatísticas no experimento com bovinos.

\begin{tabular}{|c|c|c|c|c|c|c|c|c|c|}
\hline \multicolumn{2}{|c|}{ Tratamentos } & \multicolumn{8}{|c|}{ Frações } \\
\hline Con & Mon & $\overline{\mathrm{MS}}$ & $\overline{\mathrm{PB}}$ & FB & ENN & $E E$ & NDT & FDN & FDA \\
\hline \multicolumn{10}{|c|}{ Interações } \\
\hline \multirow{3}{*}{25} & 0 & 61,54 & 65,83 & 68,54 & 61,05 & 45,10 & 60,08 & 62,27 & 56,33 \\
\hline & 150 & 68,09 & 74,94 & 76,70 & 66,02 & 53,57 & 66,13 & 69,68 & 65,28 \\
\hline & 300 & 68,08 & 74,11 & 74,05 & 66,27 & 52,23 & 65,84 & 68,09 & 63,19 \\
\hline \multirow{3}{*}{50} & 0 & 61,70 & 60,79 & 59,28 & 64,82 & 57,17 & 61,59 & 49,84 & 48,58 \\
\hline & 150 & 62,11 & 64,18 & 58,78 & 65,38 & 53,11 & 61,72 & 50,21 & 49,64 \\
\hline & 300 & 72,86 & 72,48 & 70,85 & 76,46 & 64,04 & 71,73 & 64,37 & 61,90 \\
\hline \multirow{3}{*}{75} & 0 & 44,63 & 46,73 & 17,66 & 52,05 & 48,86 & 46,76 & 19,56 & 10,45 \\
\hline & 150 & 55,32 & 58,79 & 34,00 & 60,66 & 60,55 & 56,78 & 22,22 & 25,26 \\
\hline & 300 & 61,15 & 64,18 & 36,06 & 67,75 & 46,31 & 62,24 & 29,82 & 31,74 \\
\hline \multicolumn{10}{|c|}{ Efeitos Principais } \\
\hline 25 & & 65,90 & 71,63 & 73,09 & 64,45 & 50,30 & 64,02 & 66,68 & 61,60 \\
\hline 50 & & 65,56 & 65,82 & 62,97 & 68,89 & 58,11 & 65,01 & 54,81 & 53,37 \\
\hline \multirow[t]{4}{*}{75} & & 53,70 & 56,57 & 29,24 & 60,16 & 51,91 & 55,26 & 23,87 & 22,48 \\
\hline & 0 & 55,95 & 57,78 & 48,49 & 59,31 & 50,38 & 56,14 & 43,89 & 38,45 \\
\hline & 150 & 61,84 & 65,97 & 56,49 & 64,02 & 55,74 & 61,55 & 47,37 & 46,73 \\
\hline & 300 & 67,36 & 70,26 & 60,32 & 70,16 & 54,19 & 66,60 & 54,09 & 52,28 \\
\hline \multicolumn{10}{|c|}{ Dados Médios } \\
\hline \multirow{2}{*}{\multicolumn{2}{|c|}{$\begin{array}{l}\text { Média } \\
\mathrm{CV}\end{array}$}} & 61,72 & 64,67 & 55,10 & 64,50 & 53,44 & 61,43 & 49,33 & 45,82 \\
\hline & & 18,95 & 15,96 & 42,76 & 17,52 & 22,59 & 17,03 & 42,19 & 47,69 \\
\hline \multicolumn{10}{|c|}{ Probabilidades Estatísticas } \\
\hline \multicolumn{10}{|c|}{ Concentrado } \\
\hline \multicolumn{2}{|c|}{ Linear (L) } & 0,0336 & 0,0012 & 0,0001 & NS & NS & NS & 0,0001 & 0,0001 \\
\hline & (D) & NS & NS & NS & NS & NS & NS & NS & NS \\
\hline \multicolumn{10}{|c|}{ Monensina } \\
\hline \multicolumn{2}{|c|}{ Linear (L) } & 0,0422 & 0,0045 & NS & NS & NS & 0,0441 & NS & 0,0349 \\
\hline \multicolumn{2}{|c|}{ Desvio (D) } & NS & NS & NS & NS & NS & NS & NS & NS \\
\hline \multicolumn{10}{|c|}{ Interação } \\
\hline Con $_{1}$ & $\operatorname{mon}_{L}$ & NS & NS & NS & NS & NS & NS & NS & NS \\
\hline Con $_{1}$ & $\operatorname{mon}_{\mathrm{D}}$ & NS & NS & NS & NS & NS & NS & NS & NS \\
\hline Con & $\operatorname{mon}_{\mathrm{L}}$ & NS & NS & NS & NS & NS & NS & NS & NS \\
\hline Con & $\operatorname{mon}_{\mathrm{D}}$ & NS & NS & NS & NS & NS & NS & NS & NS \\
\hline
\end{tabular}




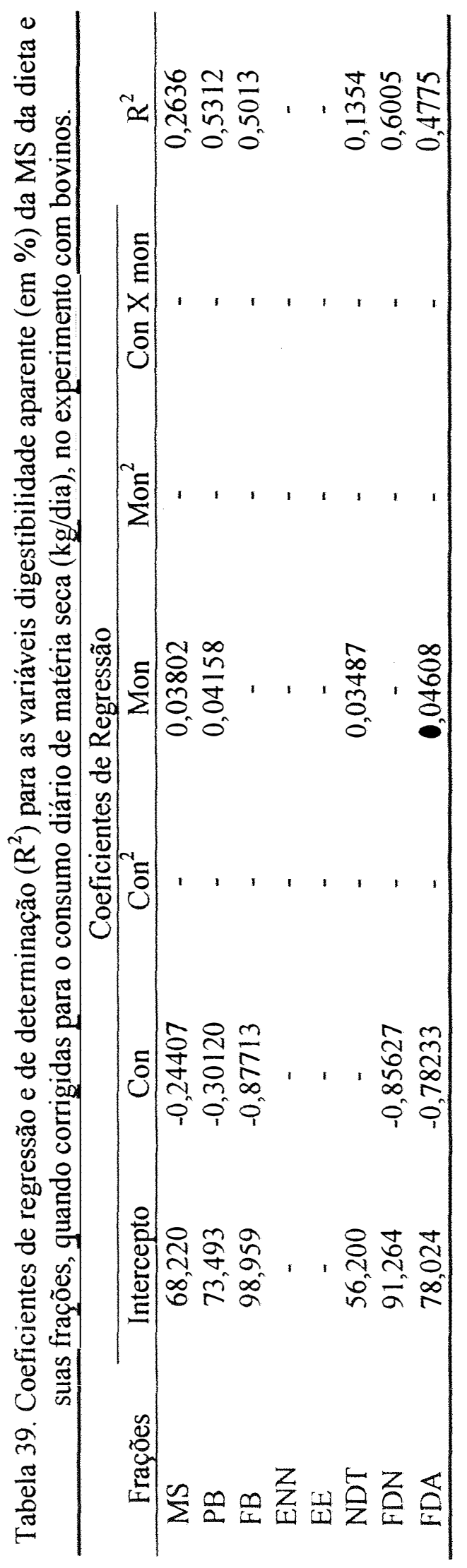



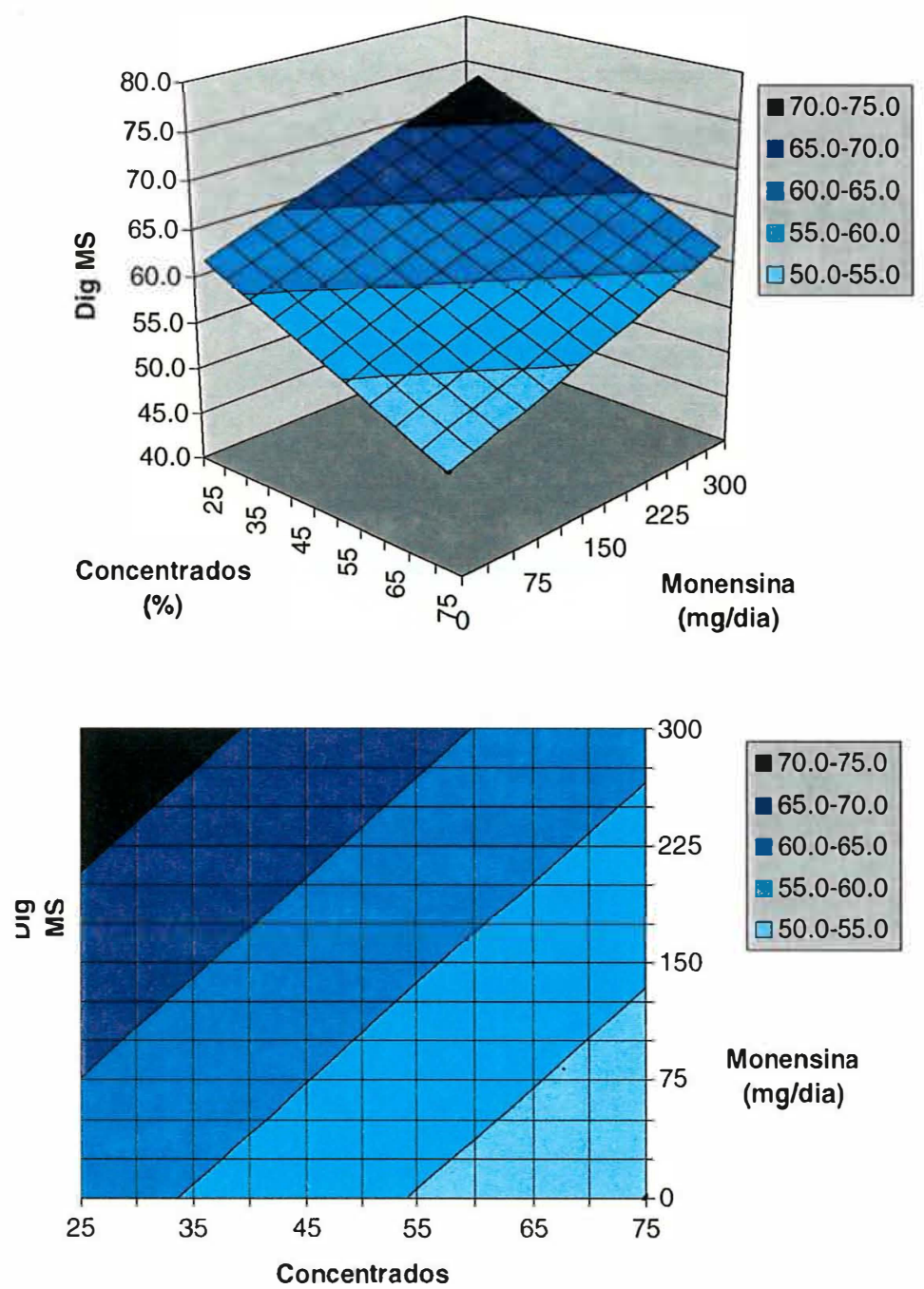

(\%)

Figura 14 - Efeitos da proporção de concentrados (\% da dieta) e dose de monensina (mg/animal/dia) sobre a digestibilidade aparente (em \%) da MS da dieta, quando corrigida para o consumo diário de matéria seca $(\mathrm{kg} / \mathrm{dia})$, obtidos no experimento com bovinos. 

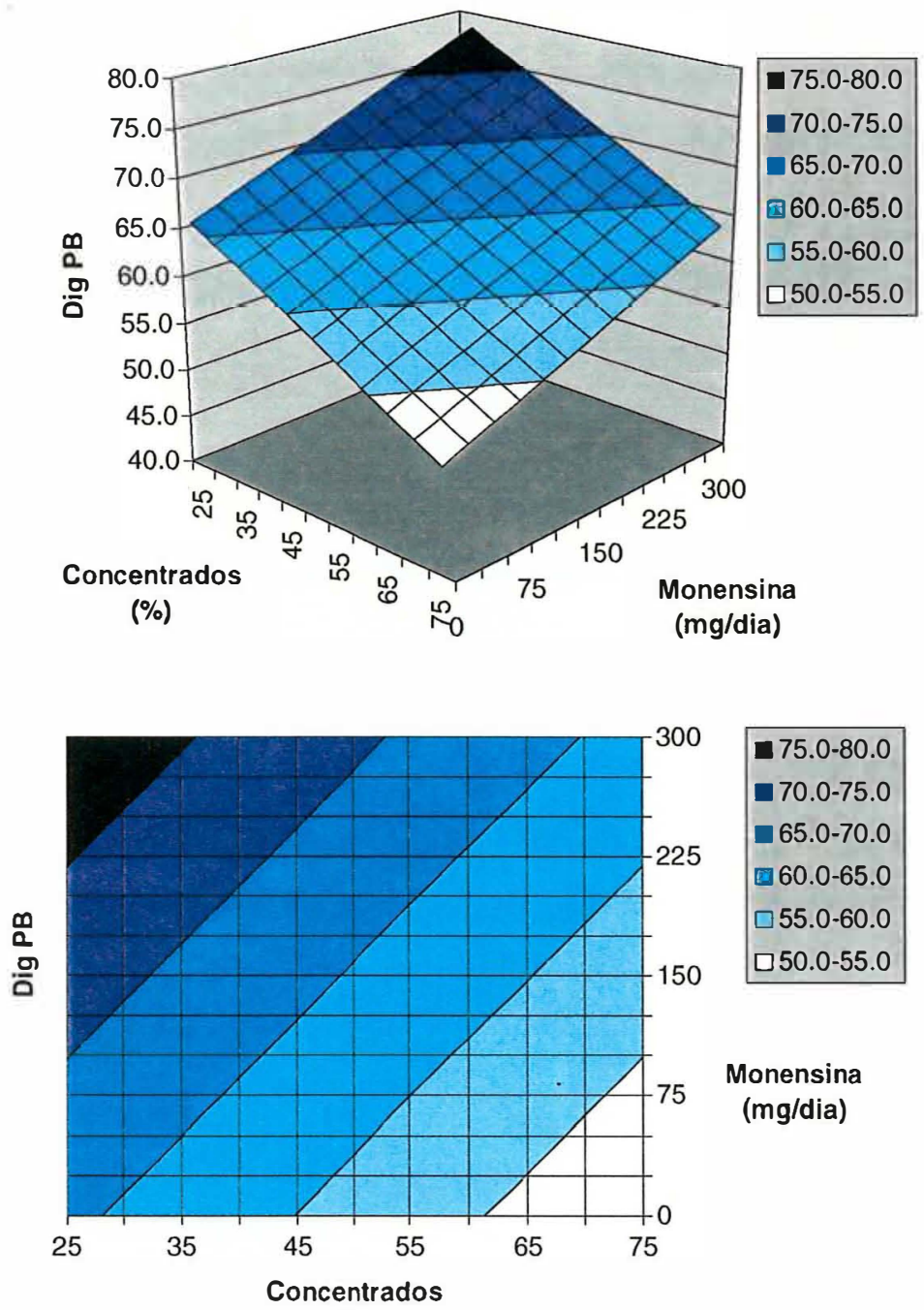

$(\%)$

Figura 15 - Efeitos da proporção de concentrados (\% da dieta) e dose de monensina (mg/animal/dia) sobre a digestibilidade aparente (em \%) da PB da dieta, quando corrigida para o consumo diário de matéria seca $(\mathrm{kg} / \mathrm{dia})$, obtidos no experimento com bovinos. 

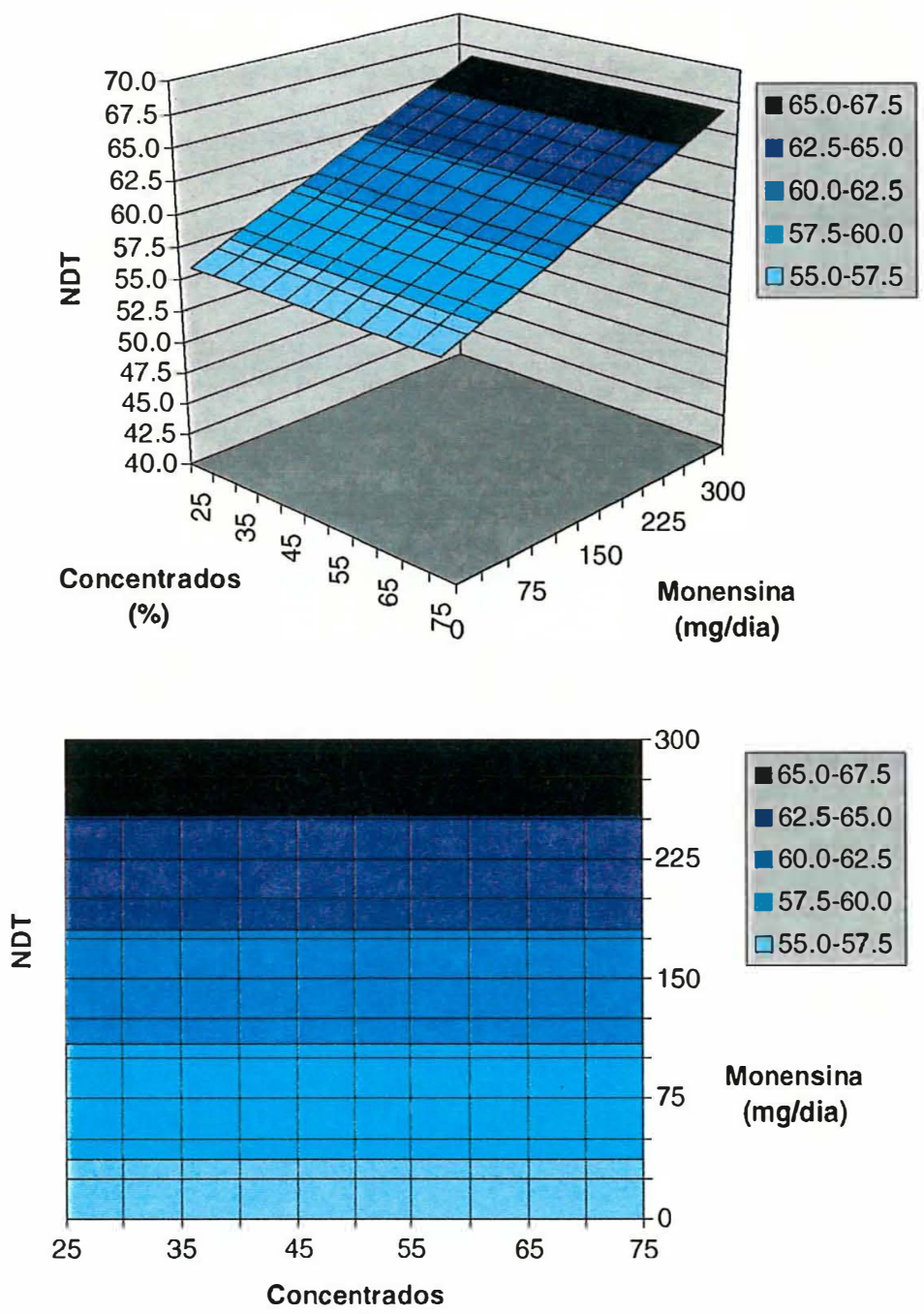

(\%)

Figura 16 - Efeitos da proporção de concentrados (\% da dieta) e dose de monensina (mg/animal/dia) sobre o NDT (em \%) da dieta, quando corrigido para o consumo diário de matéria seca $(\mathrm{kg} / \mathrm{dia})$, obtidos no experimento com bovinos. 

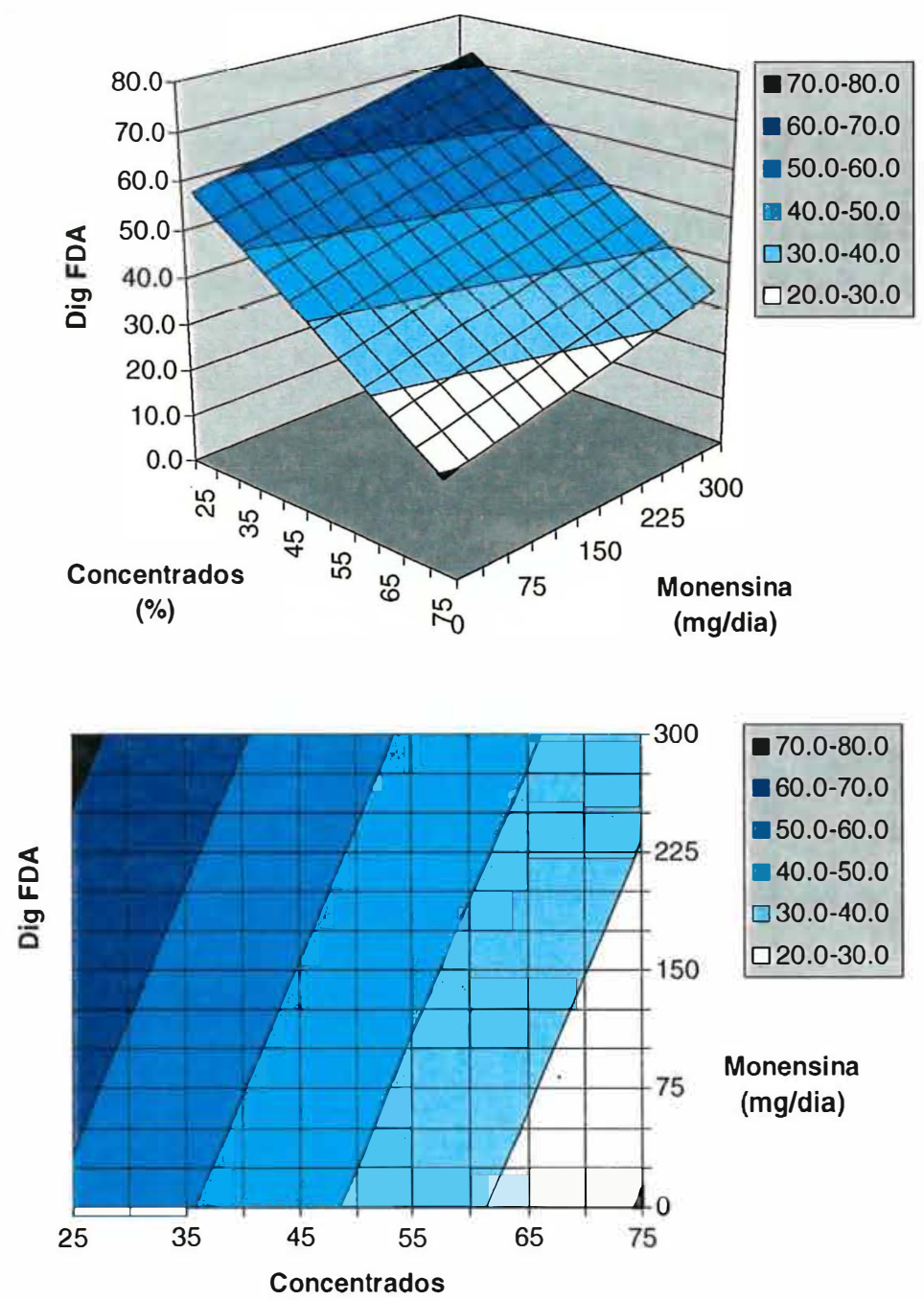

(\%)

Figura 17 - Efeitos da proporção de concentrados (\% da dieta) e dose de monensina (mg/animal/dia) sobre a digestibilidade aparente (em \%) da FDA da dieta, quando corrigida para o consumo diário de matéria seca $(\mathrm{kg} / \mathrm{dia})$, obtidos no experimento com bovinos. 
Tabela 40. Efeitos da proporção de concentrados (Con) e dose de monensina (Mon) sobre a digestibilidade aparente (em \%) da MS da dieta e suas frações, coeficientes de variação $(\mathrm{CV})$ e probabilidades estatísticas no experimento com ovinos.

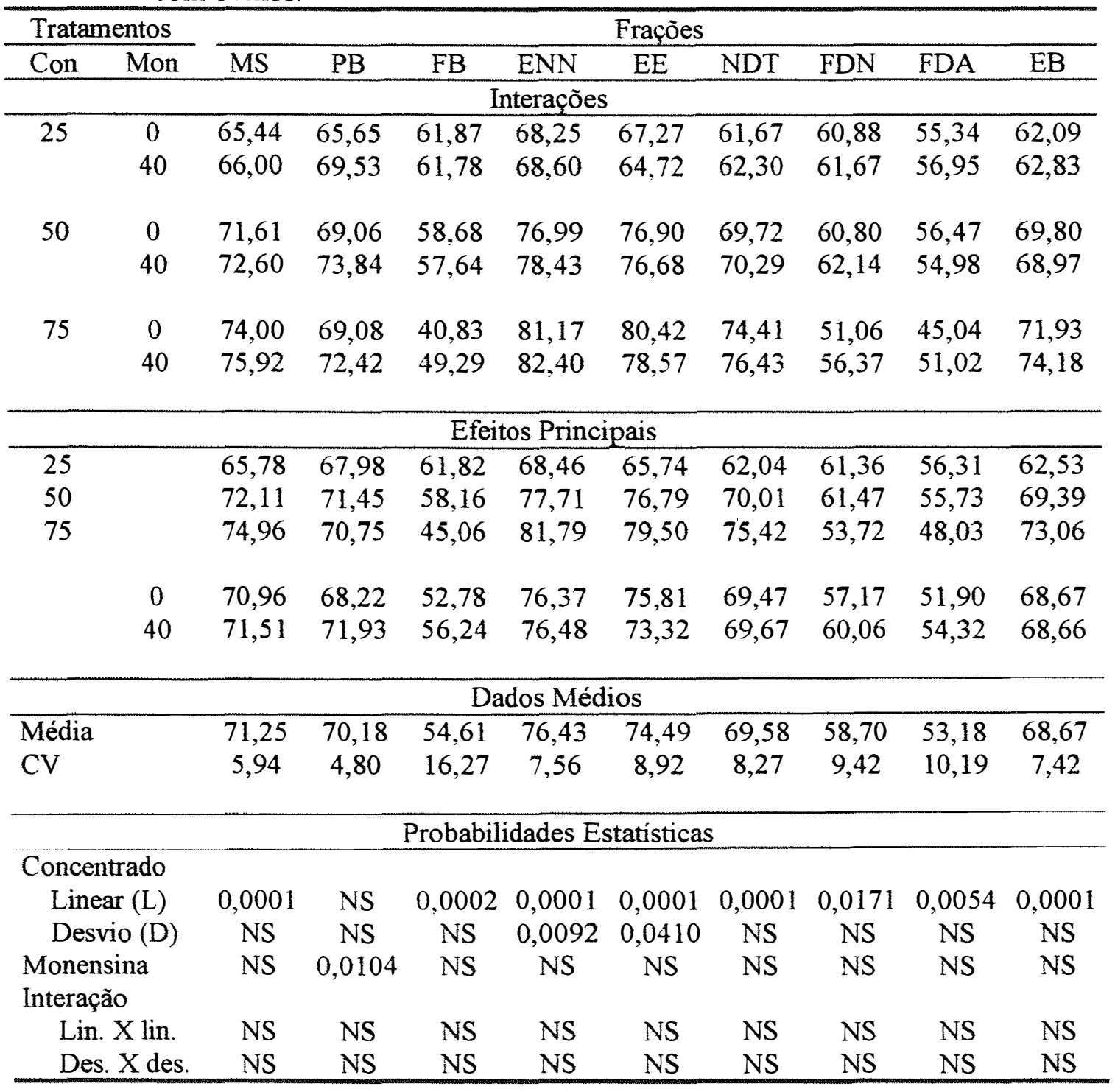




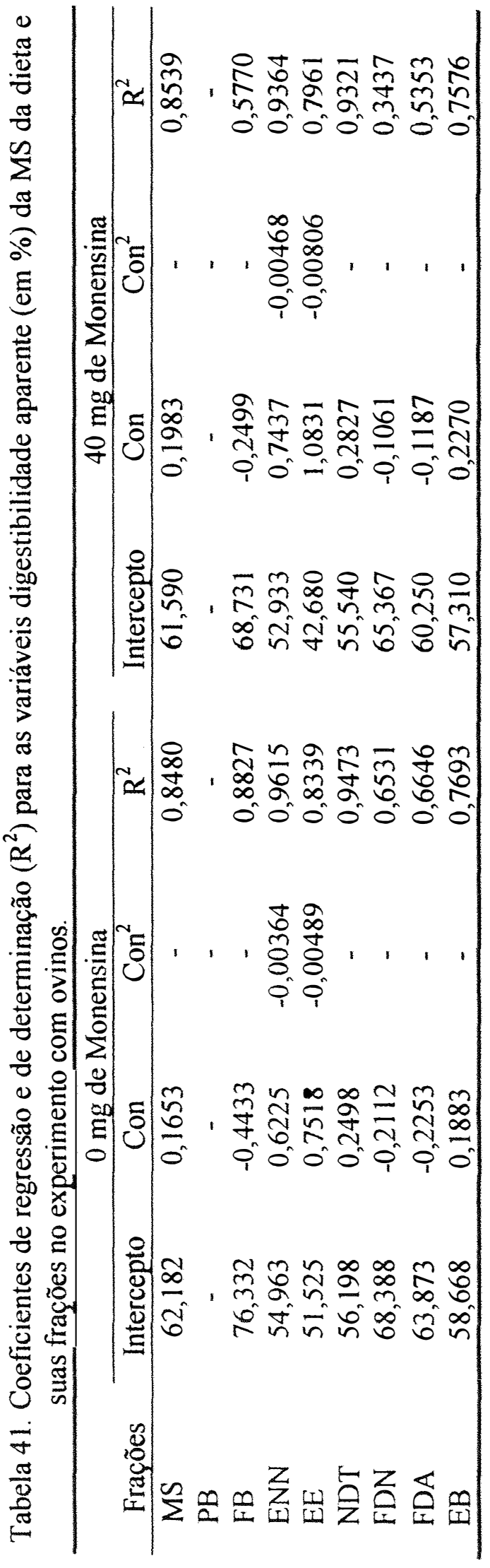


Tabela 42. Efeitos da proporção de concentrados (Con) e dose de monensina (Mon) sobre a digestibilidade aparente (em \%) da MS da dieta e suas frações, quando corrigidas para o consumo diário de matéria seca $(\mathrm{kg} / \mathrm{dia})$, coeficientes de variação $(\mathrm{CV})$ e probabilidades estatísticas no experimento com ovinos.

\begin{tabular}{|c|c|c|c|c|c|c|c|c|c|c|}
\hline \multicolumn{2}{|c|}{ Tratamentos } & \multicolumn{9}{|c|}{ Frações } \\
\hline Con & Mon & MS & $\mathrm{PB}$ & $\mathrm{FB}$ & ENN & $\mathrm{EE}$ & NDT & FDN & FDA & $E B$ \\
\hline \multicolumn{11}{|c|}{ Interaçōes } \\
\hline \multirow[t]{2}{*}{25} & 0 & 65,08 & 65,33 & 61,01 & 67,98 & 66,75 & 61,37 & 60,13 & 54,89 & 61,70 \\
\hline & 40 & 66,07 & 69,60 & 61,95 & 68,66 & 64,82 & 62,35 & 61,82 & 57,04 & 62,91 \\
\hline \multirow[t]{2}{*}{50} & 0 & 71,82 & 69,24 & 59,17 & 77,14 & 77,19 & 69,89 & 61,24 & 56,74 & 70,03 \\
\hline & 40 & 70,69 & 72,18 & 53,18 & 77,03 & 74,01 & 68,76 & 58,19 & 52,59 & 66,95 \\
\hline \multirow[t]{2}{*}{75} & 0 & 74,79 & 69,77 & 42,68 & 81,75 & 81,53 & 75,05 & 52,71 & 46,03 & 72,77 \\
\hline & 40 & 76,99 & 73,36 & 51,81 & 83,19 & 80,08 & 77,29 & 58,60 & 52,36 & 75,32 \\
\hline \multicolumn{11}{|c|}{ Efeitos Principais } \\
\hline 25 & & 65,58 & 67,46 & 61,48 & 68,32 & 65,79 & 61,86 & 60,97 & 55,96 & 62,30 \\
\hline 50 & & 71,29 & 70,71 & 56,17 & 77,09 & 75,60 & 69,33 & 59,71 & 54,67 & 68,49 \\
\hline \multirow[t]{3}{*}{75} & & 75,89 & 71,57 & 47,24 & 82,47 & 80,80 & 76,17 & 55,65 & 49,20 & 74,04 \\
\hline & 0 & 70,56 & 68,12 & 54,29 & 75,63 & 75,16 & 68,77 & 58,02 & 52,55 & 68,17 \\
\hline & 40 & 71,25 & 71,71 & 55,64 & 76,29 & 72,97 & 69,47 & 59,53 & 54,00 & 68,39 \\
\hline \multicolumn{11}{|c|}{ Dados Médios } \\
\hline \multirow{2}{*}{\multicolumn{2}{|c|}{$\begin{array}{l}\text { Média } \\
\text { CV }\end{array}$}} & 71,25 & 70,18 & 54,61 & 76,43 & 74,49 & 69,58 & 58,70 & 53,18 & 68,67 \\
\hline & & 5,94 & 4,80 & 16,27 & 7,56 & 8,92 & 8,27 & 9,42 & 10,19 & 7,42 \\
\hline \multicolumn{11}{|c|}{ Probabilidades Estatisticas } \\
\hline \multicolumn{11}{|c|}{ Concentrado } \\
\hline \multicolumn{2}{|c|}{ Linear $(L)$} & 0,0001 & 0,0261 & 0,0001 & 0,0001 & 0,0001 & 0,0001 & 0,0319 & 0,0145 & 0,0001 \\
\hline \multicolumn{2}{|c|}{ Desvio (D) } & NS & NS & NS & 0,0387 & NS & NS & NS & NS & NS \\
\hline \multicolumn{2}{|c|}{$\begin{array}{l}\text { Monensina } \\
\text { Interação }\end{array}$} & NS & 0,0139 & NS & NS & NS & NS & NS & NS & NS \\
\hline \multirow{2}{*}{\multicolumn{2}{|c|}{$\begin{array}{l}\text { Lin. X lin. } \\
\text { Des X des }\end{array}$}} & NS & NS & NS & NS & NS & NS & NS & NS & NS \\
\hline & & NS & NS & 0,0257 & NS & NS & NS & NS & NS & NS \\
\hline
\end{tabular}




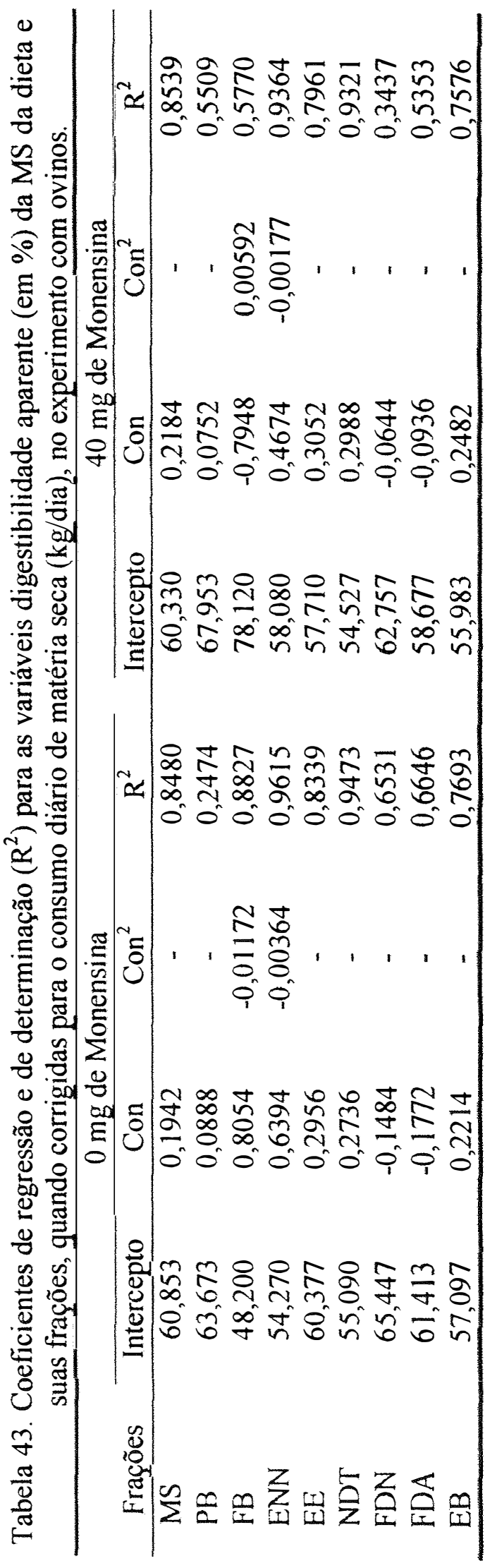




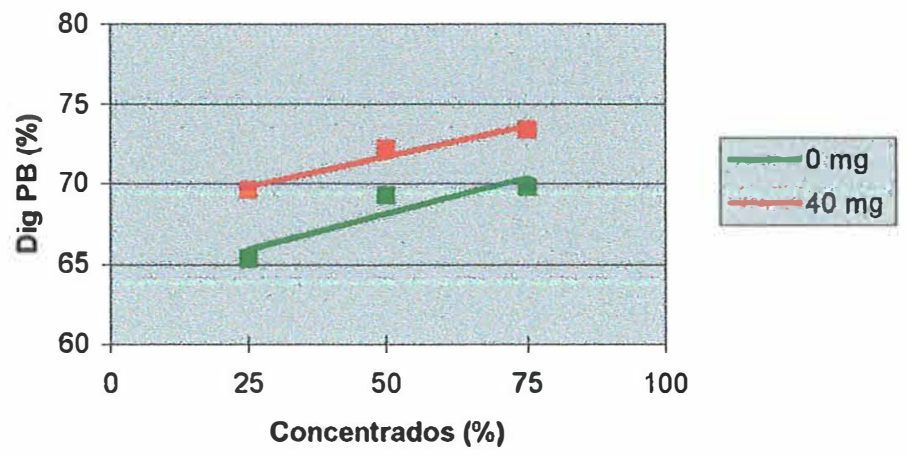

Figura 18 - Efeitos da proporção de concentrados (\% da dieta) e dose de monensina (mg/animal/dia) sobre a digestibilidade aparente (em \%) da PB da dieta, quando corrigida para o consumo diário de matéria seca $(\mathrm{kg} / \mathrm{dia})$, obtidos no experimento com ovinos. 


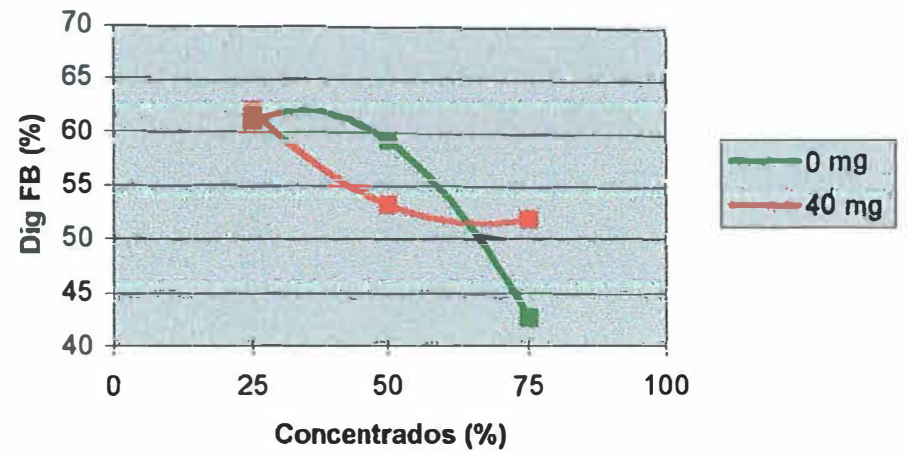

Figura 19 - Efeitos da proporção de concentrados (\% da dieta) e dose de monensina (mg/animal/dia) sobre a digestibilidade aparente (em \%) da FB da dieta, quando corrigida para o consumo diário de matéria seca $(\mathrm{kg} / \mathrm{dia})$, obtidos no experimento com ovinos. 


\subsection{Digestibilidade in vitro (etapa ruminal) do farelo de soja}

A Tabela 44 traz os valores de digestibilidade in vitro do farelo de soja, quando incubado por 12 horas, obtidos com inóculo ruminal extraído 3 ou 15 horas após a administração da monensina aos bovinos, mas respeitando-se o prazo de 3 horas entre o fornecimento dos alimentos e a coleta de inóculo.

Os tratamentos utilizados neste experimento interagiram com o fator tempo de amostragem e, ao ser realizada a análise estatística em cada tempo, observouse interação entre proporção de concentrados e dose de monensina após 3 horas de administração do produto, mas não 15 horas após. Com o inóculo obtido após 3 horas, observou-se resposta curvilinear para a proporção de concentrados e dose de monensina, com aumento da digestibilidade para doses e proporções intermediárias (Figura 20). O cálculo do ponto estacionário demonstrou que o maior valor da digestibilidade foi obtido com 59,7\% de concentrados na dieta e 176,7 mg de monensina/animal/dia.

Os dados aqui avaliados parecem concordar com o aumento causado pela monensina sobre a constante $a$ (fração rapidamente degradável) estimada a partir da equação de Ørskov \& McDonald (1979) no ensaio de digestibilidade ruminal in situ, avaliada pela técnica dos sacos de náilon, observados no presente experimento. Rodrigues (1996), ao observar o mesmo efeito sobre essa constante, propôs que, o fato do produto testado (lasalocida) ter sido administrado aos animais através da fistula ruminal (em papelotes de papel absorvente), não haveria tempo suficiente para que estes se desfizessem no rúmen e liberassem o produto. Isto faria com que as concentrações do ionóforo no rúmen fossem baixas durante o tempo que os primeiros sacos (incubação de 1,5 e 3,0 horas) também fossem incubados. Na presença dessas baixas concentrações do ionóforo, as bactérias predominantemente proteolíticas, inibidas em altas concentrações, desencadeariam uma degradação protéica exacerbada, de forma a compensar o período de inibição. Com este efeito, suspeitava-se de uma adaptação diária ao produto. 
$\mathrm{O}$ uso do teste de digestibilidade ruminal in vitro, com a mesma fonte protéica testada anteriormente, teria a função de avaliar instantaneamente a atividade das bactérias proteolíticas em momentos em que as concentrações do produto fossem provavelmente diferentes, mas sem a alteração da concentração do produto no meio de cultura que poderia ser causada pelo fluxo de líquidos pelo rúmen.

Os dados encontrados rejeitam a hipótese do possivel "efeito rebote" das bactérias sobre a digestibilidade ruminal de uma fonte protéica em prováveis condições de baixas dose de monensina. Com a metodologia adotada, parte-se do pressuposto que o maior tempo de espera para a coleta de inóculo ( 15 horas) tenha sido suficiente para fazer as concentrações do produto baixarem, uma vez que não foi possível avaliar sua concentração.

Alguns estudos in vitro têm demonstrado diminuição das concentrações de nitrogênio amoniacal no meio de cultura com o uso de ionóforos (Van Nevel \& Demeyer, 1977; Whetstone et al., 1981; Katz et al., 1986; Yang \& Russell, 1993), sendo este efeito comumente explicado pela diminuição da degradação da proteína (Van Nevel \& Demeyer, 1977; Whetstone et al., 1981). Este fato é incompativel com os resultados obtidos no presente experimento, embora outros tenham explicado tal achado devido à inibição da deaminação (Whetstone et al., 1981; Russell et al., 1988; Chen \& Russell, 1991; Van Kessel \& Russell, 1992; Yang \& Russell, 1993), podendo este efeito estar acompanhado de aumento (Yang \& Russell, 1993) ou diminuição (Bartley et al., 1979) do crescimento bacteriano no meio de cultura. 
Tabela 44. Efeitos da proporção de concentrados (Con) e dose de monensina (Mon) sobre a digestibilidade in vitro do farelo de soja (em \%) em diferentes horas de amostragem, coeficientes de variação (CV) e probabilidades estatísticas no experimento com bovinos.

\begin{tabular}{|c|c|c|c|c|}
\hline \multicolumn{2}{|c|}{ Tratamentos } & \multicolumn{2}{|c|}{ Tempo (horas) } & \multirow[b]{2}{*}{ Média } \\
\hline Con & Mon & 3 & 15 & \\
\hline \multicolumn{5}{|c|}{ Interações } \\
\hline \multirow{3}{*}{25} & 0 & 65,62 & 71,52 & 68,57 \\
\hline & 150 & 70,10 & 70,34 & 70,22 \\
\hline & 300 & 62,67 & 71,76 & 67,21 \\
\hline \multirow{3}{*}{50} & 0 & 71,45 & 72,24 & 71,85 \\
\hline & 150 & 70,09 & 75,09 & 72,59 \\
\hline & 300 & 73,98 & 74,22 & 74,10 \\
\hline \multirow{3}{*}{75} & 0 & 68,91 & 70,41 & 69,66 \\
\hline & 150 & 72,80 & 74,29 & 73,55 \\
\hline & 300 & 70,90 & 75,16 & 73,03 \\
\hline \multicolumn{5}{|c|}{ Efeitos Principais } \\
\hline 25 & & 66,13 & 71,21 & 68,67 \\
\hline 50 & & 71,84 & 73,85 & 72,85 \\
\hline \multirow[t]{4}{*}{75} & & 70,87 & 73,29 & 72,08 \\
\hline & 0 & 68,66 & 71,39 & 70,03 \\
\hline & 150 & 71,00 & 73,24 & 72,12 \\
\hline & 300 & 69,18 & 73,71 & 71,45 \\
\hline \multicolumn{5}{|c|}{ Dados Médios } \\
\hline \multirow{2}{*}{\multicolumn{2}{|c|}{$\begin{array}{l}\text { Média } \\
\mathrm{CV}\end{array}$}} & 69,61 & 72,78 & 71,20 \\
\hline & & 6,45 & 4,67 & 5,89 \\
\hline \multicolumn{5}{|c|}{ Probabilidades Estatísticas } \\
\hline \multicolumn{5}{|l|}{ Concentrado } \\
\hline Linear (L) & & 0,0046 & NS & 0,0092 \\
\hline Desvio (D) & & 0,0163 & NS & 0,0247 \\
\hline \multicolumn{5}{|l|}{ Monensina } \\
\hline Linear $(L)$ & & NS & NS & NS \\
\hline Desvio (D) & & NS & NS & NS \\
\hline \multicolumn{5}{|l|}{ Interação } \\
\hline $\mathrm{Con}_{\mathrm{L}} \mathrm{X} \mathrm{mon}_{\mathrm{L}}$ & & NS & NS & NS \\
\hline $\mathrm{Con}_{\mathrm{L}} \mathrm{X}$ mon $_{\mathrm{D}}$ & & NS & NS & NS \\
\hline $\mathrm{Con}_{\mathrm{D}} \mathrm{X} \mathrm{mon}_{\mathrm{L}}$ & & NS & NS & NS \\
\hline $\mathrm{Con}_{\mathrm{D}} \mathrm{X} \operatorname{mon}_{\mathrm{D}}$ & & 0,0169 & NS & NS \\
\hline
\end{tabular}


Tabela 44. Efeitos da proporção de concentrados (Con) e dose de monensina (Mon) sobre a digestibilidade in vitro do farelo de soja (em \%) em diferentes horas de amostragem, coeficientes de variação $(\mathrm{CV})$ e probabilidades estatísticas no experimento com bovinos.

\begin{tabular}{|c|c|}
\hline Causas de variação & $\begin{array}{l}\text { Probabilidades } \\
\text { Estatísticas }\end{array}$ \\
\hline Tempo & 0,0003 \\
\hline Tempo X concentrado (Con) & \\
\hline Tempo $X$ con $_{\text {Linear }}$ & NS \\
\hline Tempo X con Desvio & NS \\
\hline Tempo X monensina (Mon) & \\
\hline Tempo $\mathrm{X}$ mon $_{\text {Linear }}$ & NS \\
\hline Tempo X mon & NS \\
\hline Tempo X concentrado X monensina & \\
\hline Tempo X con Linear $\mathrm{X}$ mon $_{\text {Linear }}$ & NS \\
\hline Tempo X con $_{\text {Linear }} \mathrm{X}$ mon & NS \\
\hline Tempo X con Desvio $\mathrm{X}$ mon $_{\text {Linear }}$ & NS \\
\hline Tempo $X$ con ${ }_{\text {Desvio }} X$ mon $_{\text {Desvio }}$ & 0,0108 \\
\hline
\end{tabular}




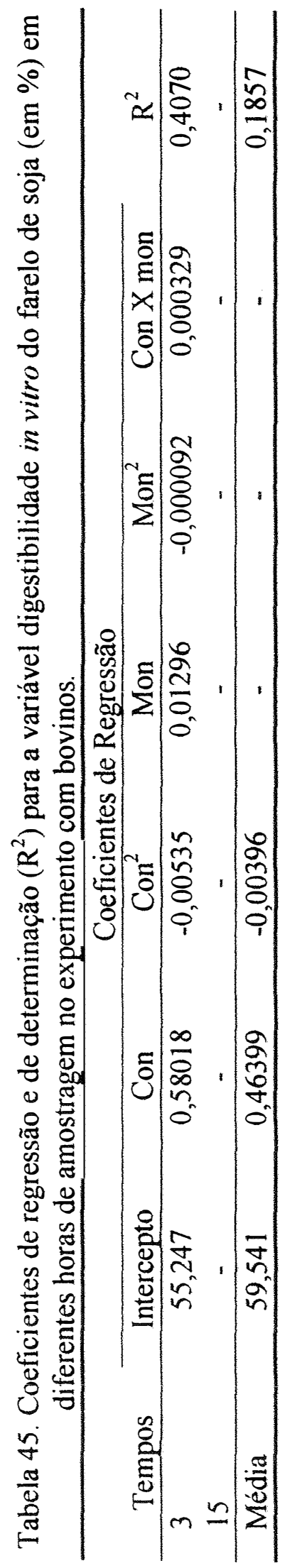



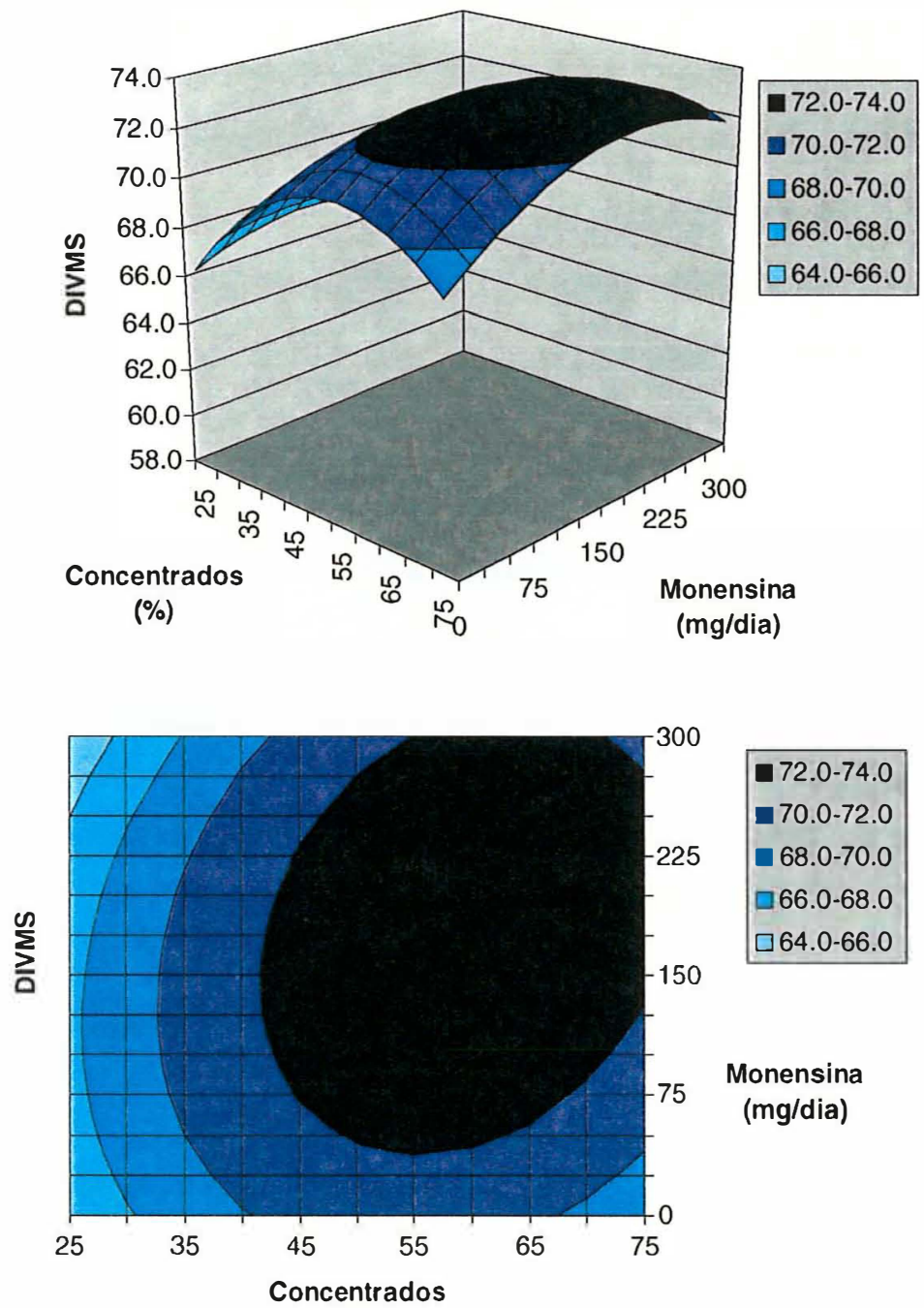

$(\%)$

Figura 20 - Efeitos da proporção de concentrados (\% da dieta) e dose de monensina (mg/animal/dia) sobre a digestibilidade in vitro do farelo de soja (em \%) com inóculo coletado 3 horas após a alimentação, obtidos no experimento com bovinos. 


\subsection{Retenção nitrogenada}

Os efeitos da dose de monensina e da proporção de concentrados na ração sobre a retenção nitrogenada, obtida no experimento com ovinos, encontra-se na Tabela 46.

Observou-se efeito linear da proporção de concentrados sobre a retenção nitrogenada, expressa em gramas de nitrogênio retido por animal e por dia $(\mathrm{RNg})$, de forma que a retenção foi aumentada em 1,0 e 2,9 gramas de N/animal/dia nas dietas mistas e predominantemente concentradas, respectivamente, quando comparadas com a dieta predominantemente volumosa. Para a variável retenção nitrogenada, expressa como porcentagem do nitrogênio retido em relação ao total de nitrogênio consumido (RN\%), observou-se interação entre os fatores dose de monensina e proporção de concentrados na ração (Figura 21). Quando separadas as interações, observou-se um comportamento curvilinear de resposta, de forma que a adição de monensina na dieta aumentou a retenção nitrogenada em 16,8 e 3,5 unidades percentuais para as dietas predominantemente volumosas e concentradas, respectivamente, mas diminuiu este parâmetro em 12,5 unidades percentuais na dieta mista.

Dinius et al. (1976) também demostraram aumento da retenção nitrogenada com a utilização de monensina na dieta de animais alimentados exclusivamente com volumosos, enquanto que Joyner et al. (1979) e Ricke et al. (1984) também o demonstraram em dietas mistas. Entretanto, outros pesquisadores não observaram efeitos dos ionóforos sobre a retenção nitrogenada (Thornton \& Owens, 1981; Rogers \& Davis, 1982; Wedegaertner \& Johnson, 1983; Funk et al., 1986; Lee et al., 1992), embora Rogers \& Davis (1982) e Wedegaertner \& Johnson (1983) tivessem observado aumento da digestibilidade. Thornton \& Owens (1981) também não demonstraram efeitos dos ionóforos sobre este parâmetro e observaram, ainda, que esta resposta não dependia da porcentagem de fibra na dieta. Achado este que discorda dos resultados presentes, embora a interpretação seja duvidosa, em decorrência do 
comportamento curvilinear aqui obtido. É bastante provável que a diminuição na retenção nitrogenada com a utilização da monensina na dieta mista seja reflexo da queda de consumo de MS obtida nesta condição, e conseqüente menor disponibilidade de energia, embora esta queda não tenha apresentado um resultado estatisticamente significativo. 
Tabela 46. Efeitos da proporção de concentrados (Con) e dose de monensina (Mon) sobre a retenção nitrogenada, expressa em gramas de nitrogênio por animal por dia $(\mathrm{RNg})$ ou porcentagem em relação ao nitrogênio absorvido (RN\%), coeficientes de variação (CV) e probabilidades estatísticas no experimento com ovinos.

\begin{tabular}{|c|c|c|c|}
\hline \multicolumn{2}{|c|}{ Tratamentos } & \multicolumn{2}{|c|}{ Retenção Nitrogenada } \\
\hline Con & Mon & $\mathrm{RNg}$ & RN\% \\
\hline \multicolumn{4}{|c|}{ Interações } \\
\hline \multirow[t]{2}{*}{25} & 0 & $-2,55$ & $-20,61$ \\
\hline & 40 & $-0,40$ & $-3,77$ \\
\hline \multirow[t]{2}{*}{50} & 0 & 0,35 & 2,04 \\
\hline & 40 & $-0,94$ & $-10,42$ \\
\hline \multirow[t]{2}{*}{75} & 0 & 1,27 & 7,94 \\
\hline & 40 & 2,02 & 11,44 \\
\hline
\end{tabular}

\begin{tabular}{|c|c|c|c|}
\hline \multicolumn{4}{|c|}{ Efeitos Principais } \\
\hline 25 & & $-1,26$ & $-10,51$ \\
\hline 50 & & $-0,30$ & $-4,19$ \\
\hline 75 & & 1,64 & 9,69 \\
\hline & 0 & $-0,03$ & $-1,41$ \\
\hline & 40 & 0,23 & $-0,92$ \\
\hline \multicolumn{4}{|c|}{ Dados Médios } \\
\hline Média & & 0,11 & $-1,15$ \\
\hline $\mathrm{CV}$ & & $1.675,60$ & $1.081,66$ \\
\hline \multicolumn{4}{|c|}{ Probabilidades Estatísticas } \\
\hline \multicolumn{4}{|l|}{ Concentrado } \\
\hline Linear $(L)$ & & 0,0016 & 0,0009 \\
\hline Desvio (D) & & NS & NS \\
\hline Monensina & & NS & NS \\
\hline \multicolumn{4}{|l|}{ Interação } \\
\hline Linear $X$ linear & & NS & NS \\
\hline Desvio $X$ desvio & & NS & 0,0171 \\
\hline
\end{tabular}




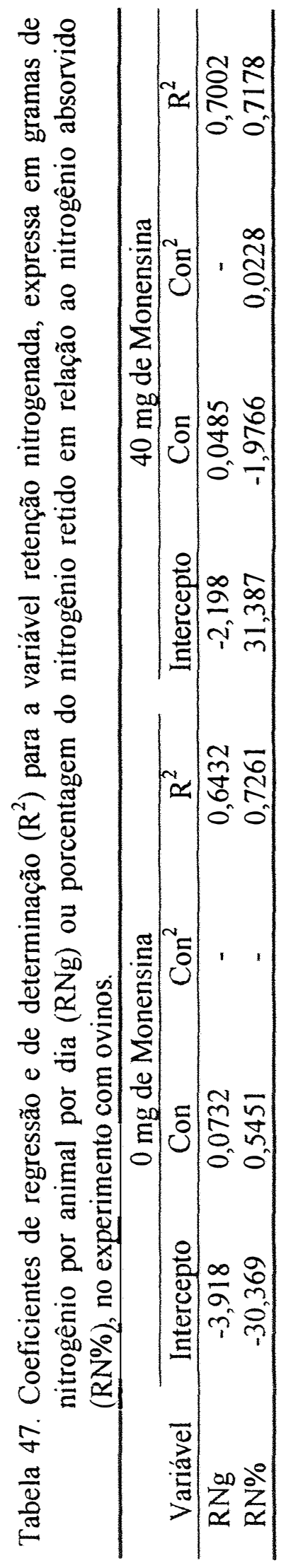




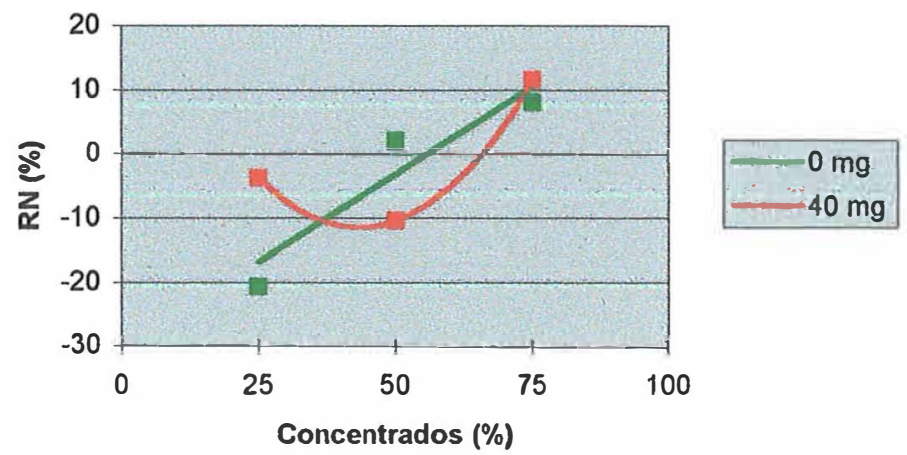

Figura 21 - Efeitos da proporção de concentrados (\% da dieta) e dose de monensina (mg/animal/dia) sobre a retenção nitrogenada, expressa em porcentagem de nitrogênio retido em relação ao nitrogênio absorvido ( $\mathrm{RN} \%$ ), obtidos no experimento com ovinos. 


\subsection{Dinâmica líquida ruminal}

Os valores de volume líquido ruminal, expressos em termos absolutos ou como porcentagem do peso vivo, taxa de passagem de líquidos, fluxo líquido por dia e fluxo líquido por quilo de MS consumida por dia, obtidos no experimento com bovinos, encontram-se na Tabela 48. Independente do tratamento, os valores de volume líquido ruminal e taxa de passagem de líquidos encontrados neste experimento foram 52,4 litros (10,5\% do peso vivo) e 11,2\%/hora, respectivamente, para animais consumindo 9,9 $\mathrm{kg}$ de MS por dia e pesando $470 \mathrm{~kg}$ de peso vivo, em média, ao início do experimento. Esses valores de volume líquido são bastante semelhantes aos 10,8\% do PV obtidos por Clary et al. (1993) utilizando a técnica do Co-EDTA em novilhos. Também parecem ser condizentes com os 9,3\% do PV obtidos por Rodrigues (1996) em vacas secas e com os $11,8 \%$ do PV encontrados por Rodriguez et al. (1986) em novilhos de corte e vacas Jersey, ao utilizarem o PEG como marcador de fase líquida. Condizente também com os $11,9 \%$ do PV obtidos por Yang \& Russell (1993) em vacas não lactantes, mas bem maiores que os $25,0 \%$ do PV encontrados por Jacques et al. (1987) em novilhos, quando ambos utilizaram o Co-EDTA. Dados de volume líquido ruminal obtidos por Lemenager et al. (1978) foram tão altos quanto 174,2 e 236,2 litros em animais suplementados ou não com monensina, respectivamente, o que foi explicado pelo fato do marcador (PEG) ter sido administrado por via oral, resultando em passagem direta do cárdia para 0 omaso, sem a completa dispersão para dentro do rúmen.

A taxa de passagem de líquidos aqui encontrada foi bastante semelhante aos $9,7 \% / \mathrm{h}, 9,8 \% / \mathrm{h}$ e 10,9\%/h obtidos por Branine \& Galyean (1990), Rodrigues (1996) e Rogers \& Davis (1982), respectivamente; um pouco acima dos 8,5\%/h, 8,0\%/h e 7,0\%/h encontrados por Rodriguez et al. (1986), Jacques et al. (1987) e Yang \& Russell (1993), respectivamente, e muito superior ao 6,5\%/h, 5,5\%/h e 4,9\%/h obtidos por Clary et al. (1993), Lemenager et al. (1978) e Faulkner et al. (1985), respectivamente, ao se considerar bovinos de diferentes pesos recebendo diferentes dietas. 
Não foi observado nenhum efeito dos fatores testados no presente experimento sobre volume líquido ruminal, expresso em termos absolutos ou como porcentagem do peso vivo, e taxa de passagem de líquidos, embora a proporção de concentrados, mas não a dose de monensina, tenha alterado linearmente o fluxo líquido por dia e o fluxo líquido por quilo de MS consumida por dia. A diminuição do fluxo líquido causada pelo aumento da proporção de concentrados foi da ordem de 9,3 a 27,7 litros por dia $(6,2 \%$ a $18,6 \%)$ e 4,1 a 4,7 litros por quilo de matéria seca consumida por $\operatorname{dia}(23,3 \%$ a $27,0 \%)$, em relação à dieta predominantemente volumosa. Diminuições da taxa de diluição da fase líquida em animais recebendo dietas concentradas, quando comparadas à dietas volumosas, também foram observadas por Hodgson \& Thomas (1972, citado por Chalupa, 1977), Bauman et al. (1971, citado por Chalupa, 1977) Topps et al. (1968, citado por Chalupa, 1977), Rode et al. (1985) e Rodrigues (1996). O aumento da taxa de passagem afeta os microorganismos ruminais e seus metabolismos, resultando em maior escape do amido e aminácidos para o duodeno e diminuição da recuperação do hidrogênio como AGVs, devido ao alargamento na relação acetato:propionato (Chalupa, 1977). Segundo tais princípios, o aumento da taxa de passagem é vantajoso somente para situações em que partículas sólidas não requeiram digestão ou síntese pré-grástrica. No presente experimento, a maior taxa de passagem de líquidos, obtida nas dietas ricas em volumoso, deve ter aumentado o nitrogênio amoniacal chegando ao abomaso e, consequentemente, diminuído seu aproveitamento.

A ausência de resultados obtidos com a administração de ionóforo no presente experimento é concordante aos obtidos por Rogers \& Davis (1982), Ricke et al. (1984), Rodriguez et al. (1986), Branine \& Galyean (1990), Clary et al. (1993), Yang \& Russell (1993), Knowlton et al. (1996b), Rodrigues (1996), Castro (1998) e Amaro (1999) com relação ao volume líquido ruminal e Poos et al. (1979), Rogers \& Davis (1982), Faulkner et al. (1985), Rodriguez et al. (1986), Jacques et al. (1987), Clary et al. (1993), Yang \& Russell (1993), Knowlton et al. (1996b), Rodrigues (1996), Castro (1998) e Amaro (1999) com relação à taxa de passagem de líquidos. Entretanto, são discordantes dos obtidos por Lemenager et al. (1978), os quais demostraram diminuição 
do volume líquido ruminal e da taxa de passagem de líquidos, e Ricke et al. (1984), que demostraram que os ionóforos tenderam em diminuir a taxa de passagem de líquidos. São também discordantes dos obtidos por Jacques et al. (1987), que demonstraram que a lasalocida causou tendência em aumentar o fluxo líquido e o volume ruminal, bem como dos encontrados por Branine \& Galyean (1990), que observaram aumento da taxa de passagem de líquidos ao utilizarem a monensina.

Os resultados obtidos neste experimento substanciam mais uma vez a teoria de Rogers \& Davis (1982) de que, em estudos onde se observa redução no consumo de alimentos, a taxa de diluição de líquidos no rúmen seria diminuída, em virtude de marcantes reduções na ingestão de água e no fluxo salivar. Os autores também afirmaram que a diminuição na ingestão de alimentos permitiria um aumento no tempo de retenção da matéria seca no rúmen, o qual seria em grande parte responsável pelos efeitos dos ionóforos. 
Tabela 48. Efeitos da proporção de concentrados (Con) e dose de monensina (Mon) sobre o volume líquido ruminal (VL), em litros, volume líquido como porcentagem do peso vivo (VL/PV), em porcentagem, taxa de passagem (TP), em porcentagem por hora, fluxo de passagem de líquidos por dia (FL), em litros, fluxo líquido por quilo de matéria seca consumida por dia (FL/CMS), em litros, coeficientes de variação $(\mathrm{CV})$ e probabilidades estatísticas no experimento com bovinos.

\begin{tabular}{|c|c|c|c|c|c|c|}
\hline \multicolumn{2}{|c|}{ Tratamentos } & \multicolumn{5}{|c|}{ Parâmetros de Dinâmica Líquida } \\
\hline Con & Mon & $\mathrm{VL}$ & $\mathrm{VL} / \mathrm{PV}$ & TP & FL & FL/CMS \\
\hline \multicolumn{7}{|c|}{ Interaçǒes } \\
\hline \multirow{3}{*}{25} & 0 & 52,68 & 11,27 & 11,47 & 142,67 & 17,62 \\
\hline & 150 & 57,18 & 10,51 & 12,09 & 155,67 & 18,77 \\
\hline & 300 & 54,85 & 11,18 & 11,32 & 147,91 & 15,65 \\
\hline \multirow{3}{*}{50} & 0 & 49,06 & 9,78 & 15,32 & 165,05 & 13,10 \\
\hline & 150 & 52,46 & 11,17 & 11,48 & 143,52 & 13,94 \\
\hline & 300 & 49,70 & 9,48 & 9,30 & 109,80 & 12,87 \\
\hline \multirow{3}{*}{75} & 0 & 60,61 & 11,29 & 8,79 & 124,65 & 12,73 \\
\hline & 150 & 45,61 & 9,06 & 10,79 & 118,60 & 13,50 \\
\hline & 300 & 49,17 & 10,37 & 10,27 & 119,86 & 11,74 \\
\hline \multicolumn{7}{|c|}{ Efeitos Principais } \\
\hline 25 & & 54,90 & 10,99 & 11,63 & 148,75 & 17,35 \\
\hline 50 & & 50,41 & 10,14 & 12,03 & 139,46 & 13,30 \\
\hline \multirow[t]{4}{*}{75} & & 51,80 & 10,24 & 9,95 & 121,04 & 12,66 \\
\hline & 0 & 54,12 & 10,78 & 11,86 & 144,12 & 14,48 \\
\hline & 150 & 51,75 & 10,24 & 11,45 & 139,26 & 15,40 \\
\hline & 300 & 51,24 & 10,34 & 10,30 & 125,85 & 13,42 \\
\hline \multicolumn{7}{|c|}{ Dados Médios } \\
\hline \multirow{2}{*}{\multicolumn{2}{|c|}{$\begin{array}{l}\text { Média } \\
\text { CV }\end{array}$}} & 52,37 & 10,46 & 11,20 & 136,41 & 14,44 \\
\hline & & 17,74 & 21,92 & 30,82 & 20,42 & 25,23 \\
\hline \multicolumn{7}{|c|}{ Probabilidades Estatísticas } \\
\hline \multicolumn{7}{|c|}{ Concentrado } \\
\hline \multicolumn{2}{|c|}{ Linear $(\mathrm{L})$} & NS & NS & NS & 0,0442 & 0,0097 \\
\hline \multicolumn{2}{|c|}{ Desvio (D) } & NS & NS & NS & NS & NS \\
\hline \multicolumn{7}{|c|}{ Monensina } \\
\hline \multicolumn{2}{|c|}{ Linear (L) } & NS & NS & NS & NS & NS \\
\hline \multicolumn{2}{|c|}{ Desvio (D) } & NS & NS & NS & NS & NS \\
\hline \multicolumn{7}{|c|}{ Interação } \\
\hline Con $_{1}$ & & NS & NS & NS & NS & NS \\
\hline Con $_{1}$ & & NS & NS & NS & NS & NS \\
\hline Con & & NS & NS & NS & NS & NS \\
\hline Con & & NS & NS & NS & NS & NS \\
\hline
\end{tabular}




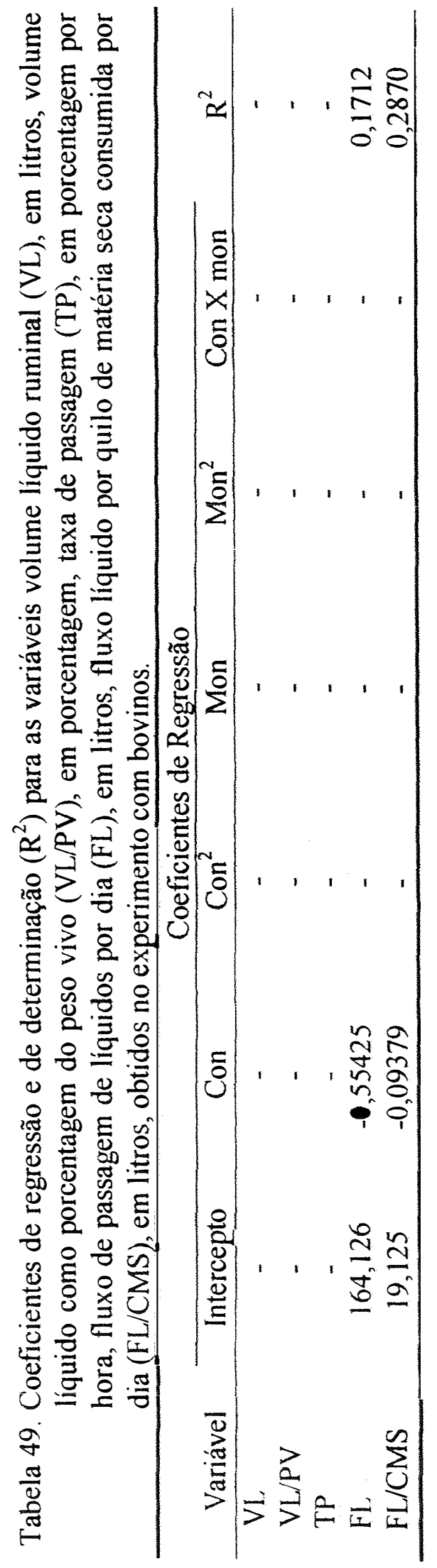




\section{CONCLUSÕES}

As seguintes conclusões podem ser enumeradas a partir dos resultados obtidos no presente experimento:

1) Para as variáveis $\mathrm{pH}$, proporções molares dos ácidos acético, propiônico e butírico, proporção acético:propiônico, concentração de nitrogênio amoniacal no líquido ruminal, digestibilidade ruminal da fibra e dos grãos de milho, a resposta à monensina varia com o nível de fibra da dieta e a dose do produto. De forma geral, a resposta à monensina é menor em dietas com altos níveis em fibra, sendo suficientes baixas doses do produto para desencadear respostas máximas, ou próximas a ela, nessas condições. Contrariamente, a resposta à monensina é maior em dietas com baixos níveis em fibra, sendo necessárias maiores doses do produto para desencadear respostas máximas. Excetuando a digestibilidade ruminal da fibra, a monensina melhora todos estes parâmetros.

2) Para as variáveis consumo de matéria seca e retenção nitrogenada, a resposta à monensina varia, ou tende a variar, com o nível de fibra na dieta, ocorrendo as maiores depressões em resposta à monensina nas dietas mistas.

3) Para as variáveis concentração total dos AGVs maiores, digestibilidade ruminal da proteína bruta, digestibilidade total da matéria seca, da proteína bruta, da fibra bruta e os nutrientes digestíveis totais, a resposta à monensina é independente do nível de fïbra da 
dieta. A monensina melhora todas estas variáveis, excetuando a concentração total dos AGVs maiores.

4) Para as variáveis digestibilidade total do extrato etéreo e dos extrativos não nitrogenados, bem como para os parâmetros de dinâmica líquida ruminal, não existe efeito da monensina qualquer que seja a dieta. 


\section{REFERÊNCIAS BIBLIOGRÁFICAS}

A.F.R.C. Technical Committee on Responses to Nutrients. Report No.9. Nutritive requirements of ruminants animals: protein. Nutrition Abstracts and Reviews, v.62, n.12, p.787-835, 1992.

ALLISON, M.L.; BRYANT, M.P. Volatile fatty acid as growth factor for cellulolytic cocci of bovine rumen. Science, v.128, p.474-475, 1958.

A.O.A.C. Official Methods of Analysis. Association of Official Analytical Chemists, 10 ed., Washington D.C., 1980.

AMARO, F.R. Tempos de ação dos efeitos da lasalocida sobre parâmetros da fermentação ruminal, em bovinos. Pirassununga, 1999. 94p. Dissertação (Mestrado) - Faculdade de Medicina Veterinária e Zootecnia, Universidade de São Paulo.

ARAUJO-FEBRES, O.; FERNÁNDEZ, M.C. Efecto en novillos del monensin y el nivel de fibra de la dieta sobre el consumo y la digestibilidad de la materia seca. Revista de la Facultad de Agronomía, Universidad del Zulia, v. 8, n.2, p. 143-153, 1991.

ARCARO, J.R.P. Efeitos da lasalocida sódica sobre o desempenho e composição do leite de vacas Holandesas e Pardo Suiças. Pirassununga, 1998. 96p. Dissertação (Mestrado) - Faculdade de Medicina Veterinária e Zootecnia, Universidade de São Paulo.

BAILE, C.A.; McLAUGHLIN, C.L.; POTTER, E.L.; CHALUPA, W. Feeding behavior changes of cattle during introduction of monensin with roughage or concentrate diets. Journal of Animal Science, v.48, n.6, p. 1501-1508, 1979.

BARRIO, J.R.; GOETSCH, A.L.; OWENS, F.N. Effect of dietary concentrate on in situ dry matter and nitrogen disappearance of a variety of feedstuffs. Journal of Dairy Science, v.69, n.2, p.420-430, 1986. 
BARRIO, J.R.; OWENS, F.N.; GOETSCH, A.L. Soluble nutrients in protein supplements and in situ disappearance. Canadian Journal of Animal Science, v.65, p.667-672, 1985.

BARTLEY, E.E.; HEROLD, E.L.; BECHTLE, R. M.; SAPIENZE, D.A.; BRENT, B.E. Effect of monensin or lasalocid, with and without niacin or aminocloral on rumen fermentation and feed efficiency. Journal of Animal Science, v.49, n.4, p.10661075, 1979.

BATEMAN, J. Nutricion Animal - Manual de Métodos Analíticos. México: Herrero Hermanos, 1970. p.405-449.

BAUMGARDT, B.R.; TAYLOR, M.W.; CASON, J.L. Evaluation of forages in the laboratory. II. Simplified rumen procedure for obtaining reapeatable estimates of forage nutritive value. Journal of Dairy Science, v.45, n. 1, p.62-68, 1962.

BEACOM, S.E.; MIR, Z.; KORSRUD, G.O.: YATES, W.D.G.; MacNEIL, J.D. Effect of the feed additives chlortetracycline, monensin and lasalocid on feedlot performance of finishing cattle, liver lesions and tissue levels of chlortetracycline.

Canadian Journal of Animal Science, v.68, n.4, p.1131-1141, 1988.

BEEDE, D.K.; BATES, D.B.; HRCHERT, E.M.; ROMERO, F.; O'CONNOR A.M.; SCHWINGEL, W. R.; DeLORENZO, M. A.; WILCOX, C. J. Lactational performance of midlactation Holstein cows fed lasalocid. Journal of Animal Science, v.63, 1986a. p.417, suplemento 1.

BEEDE, D.K.; SCHELLING, G.T.; MITCHELL, G.E.; TUCKER, R.E.; GILL, W.W.; KOENIG, S.E.; LINDSEY, T.O. Nitrogen utilization and digestibility by growing steers and goats of diets that contain monensin and low crude protein. Journal of Animal Science, v.62, n.3, p.857-863, 1986b.

BEM, C.H.W. Efeito de bicarbonato de sódio e/ou lasalocida sobre a digestibilidade de dietas com bagaço de cana. Piracicaba, 1991. 73p. Dissertação (Mestrado) - Escola Superior de Agricultura "Luiz de Queiroz", Universidade de São Paulo.

BENZ D.A.; JOHNSON, D.A. The effect of monensin on energy partitioning by forage feed steers. Journal of Animal Science, v.55, 1982. p.491, suplemento, 1.

BERGEN, W.G.; BATES, D.B. Ionophores: Their effect on production efficiency and mode of action. Journal of Animal Science, v.58, n.6, p. 1465-1483, 1984.

BOGAËRT, C.; GOMEZ, L.; JOUANY, J.P. Effects of lasalocid and cationomycin on the digestion of plant cell walls in sheep. Canadian Journal of Animal Science, v.71, n.2, p.379-388, 1991. 
BOGAËRT, C.; GOMEZ, L.; JOUANY, J.P.; JEMINET, G. Effects of the ionophore antibiotics lasalocid and cationomycin on ruminal fermentation in vitro (RUSITEC). Animal Feed Science and Technology, v.25, p.169, 1989.

BRANINE, M.E.; GALYEAN, M.L. Influence of grain and monensin supplementation on ruminal fermentation, intake, digesta kinetcs and incidence and severity of frothy bloat in steers grazing winter wheat pasture. Journal of Animal Science, v.68, n.3, p.1139-1150, 1990.

BROWN, D.L.; HOGUE, D.E. Effects of feeding monensin sodium to lactating goats: Milk composition and ruminal volatile fatty acids. Journal of Dairy Science, v.68, n.5, p. 1141-1147, 1985 .

CALLAWAY, T.R.; MARTIN, S.A. Effects of cellobiose and monensin on in vitro fermentation of organic acids by mixed ruminal bacteria. Journal of Dairy Science, v.80, n.6, p.1126-1135, 1997.

CASTRILLO, C.; LAINEZ, M.; CASA, J.; GUADA, J.A. The effect on increasing the proportion of barley straw in pelleted concentrate diets given to lambs on rumen outflow rate and degradation of protein supplements. Animal Production, v.54, n.1, p.59-66, 1992.

CASTRO, A.L. Efeitos da lasalocida sódica sobre a digestibilidade de dietas contendo cana-de-açúcar (Saccharun officinarum) em bovinos com fistula ruminal. Pirassununga, 1998. 95p. Dissertação (Mestrado) - Faculdade de Medicina Veterinária e Zootecnia, Universidade de São Paulo.

CHALUPA, W. Manipulating rumen fermentation. Journal of Animal Science, v.45, n.3, p. $585-599,1977$.

CHALUPA, W.; CORBETT, W.; BRETHOUR, J.R. Effects of monensin and amicloral on rumen fermentation. Journal of Animal Science, v.51, n. 1, p.170-179, 1980.

CHEN, G.; RUSSELL, J.B. Effect of monensin and a protonophore on protein degradation, peptide accumulation, and deamination by mixed ruminal microorganisms in vitro. Journal of Animal Science, v.69, n.5, p.2196-2203, 1991.

CHEN, G.; RUSSELL, J.B. Sodium-dependent transport of branched-chain amino acids by a monensin-sensitive ruminal Peptostreptococcus. Applied Environmental Microbiology, v.55, n.10, p.2658-2663, 1989.

CHEN, M.; WOLIN, M.F. Effect of monensin and lasalocid on the growth of rumen and methane bacteria. American Society of Microbiology, 78th Annu. Meet., 1978. p.88. 
CHEN, M.; WOLIN, M.F. Effect of monensin and lasalocid-sodium on the growth of methanogenic and saccharolytic bacteria. Applied Environmental Microbiology, v.38, n.1, p. 72-77, 1979.

CHOW, J.M.; RUSSELL, J.B. Effect of ionophores and pH on growth of Streptococcus bovis in bath and continuous culture. Applied Environmental Microbiology, v.56, p. $1588,1990$.

CHOW, J.M.; RUSSELL, J.B. Effect of $\mathrm{pH}$ and monensin on glucose transport by Fibrobacter succinogenes, a cellulolytic ruminal bacterium. Applied Environmental Microbiology, v.58, n.4, p.1115-1120, 1992.

CHURCH, D.C.; POND, W.G. Basic Animal Nutrition and feeding. New York: John Wiley \& Sons, 1988. 472p.

CLARY, E.M.; BRANDT, R.T.; HARMON, D.L.; NAGARAJA, T.G. Supplemental fat and ionophores in finishing diets: feedlot preformance and ruminal digesta kinetics in steers. Journal of Animal Science, v.71, n. 11, p.3115-3123, 1993.

CONRAD, H.R.; PRATT, A.D.; HIBBS, J.W. Regulation of feed intake in dairy cows. I. Change in importance of physical and physiological factors with increasing digestibility. Journal of Dairy Science, v.47, p.45, 1964.

CUMMINS, K.A.; NOCEK, J.E.; POLAN, C.E.; HERBEIN, J.H. Nitrogen degradability and microbial protein synthesis in calves fed diets of varying degradability by the bag technique. Journal of Dairy Science, v.66, n.11, p.2356-2364, 1983.

DARDEN, D.E.; MERCHEN, N.R.; BERGER, L.L.; FAHEY, G.C. Effects of avoparcin, lasalocid, and monensin on sites of nutrient digestion in beef steers. Nutrition Reports International, v.31, n.4, p.979-989, 1985.

Da SILVA, S.C. Efeito de bicarbonato de sódio e/ou lasalocida sobre parâmetros ruminais de bovinos alimentados com bagaço de cana tratado a pressão de vapor. Piracicaba, 1990. 120p. Dissertação (Mestrado) - Escola Superior de Agricultura "Luiz de Queiroz", Universidade de São Paulo.

DAVIS, G.V.; ERHART, A.B. Effects of monensin and urea in finishing steer rations. Journal of Animal Science, v. 43, n. 1, p. 1-8, 1976.

DAWSON, K.A.; BOLING, J. Effects of potassium ion concentration on the antimicrobiol activities of ionophores against ruminal anaerobes. Applied Environmental Microbiology, v.53, p.2636, 1987. 
DINIUS, D.A.; SIMPSON, M.S.; MARSH, P.B. Effect of monensin with forage on digestion and the ruminal ecosystem of steers. Journal of Animal Science, v.42, n. 1, p.229-234, 1976.

DUFF, G.C.; GALYEAN, M.L.; BRANINE, M.E. Effects of adaptation to lasalocid, monensin or a daily rotation of lasalocid and monensin on in vitro fermentation of a 90\% concentrate diet. Canadian Journal of Animal Science, v.75, n. 1, p.129-134, 1995 .

DUFFIELD, T.F.; SANDALS, D.; LESLIE, K.E.; LISSEMORE, K.; McBRIDE, B.W.; LUMSDEN, J.H.; DIKC, P.; BAGG, R. Efficacy of monensin for the prevention of subclinical ketosis in lactating dairy cows. Journal of Dairy Science, v.81, n. 11 p.2866-2873, 1998.

DYE, B.E.; AMOS, H.E.; FROETSCHEL, M.A. Influence of lasalocid on rumen metabolites, milk production, milk composition and digestibility in lactating cows. Nutrition Reports International, v.38, n.1, p.101-115, 1988.

ELLIS, W.C.; HORN G.W.; DELANEY, D.; POND, K.R. Effects of ionophores on grazed forage utilization and their economic value for cattle on wheat pasture. In: Proceedings of National Wheat Pasture Symposium, Stillwater: Oklahoma Agric. Exp. Sta. MP 115, 1983. p.343.

ERWIN, E.S.; MARCO, G.J.; EMERY, E.M. Volatile fatty acid analyses of blood and rumen fluid by gas chromatography. Journal of Dairy Science, v.44, n.9, p.1768$1771,1961$.

FAULKNER, D.B.; KLOPFENSTEIN, T.J.; TROTTER, N.T.; BRITTON, R.A. Monensin effects on digestibility, ruminal protein escape and microbial protein synthesis on high-fiber diets. Journal of Animal Science, v.61, n.3, p.654-660, 1985.

FELLNER, V.; SAUER, F.D.; KRAMER, J.K.G. Effect of nigericin, monensin, and tetronasin on biohydrogenation in continuous flow-through ruminal fermenters. Journal of Dairy Science, v.80, n.5, p.921-928, 1997.

FOLDAGER, J. Protein requirement and non protein nitrogen for high producing cow in early lactation. East Lasing, 1977. Thesis (Ph.D.) - Michigan State University.

FRANCISCO JR., J.C. Efeito da uréia, do melaço e da lasalocida sódica sobre a fermentação ruminal em bovinos alimentados com bagaço de cana-de-açúcar tratado a pressão e vapor. Piracicaba, 1994. 105p. Dissertação (Mestrado) - Escola Superior de Agricultura "Luiz de Queiroz", Universidade de São Paulo. 
FREDRICKSON, E.L.; GALYEAN, M.L.; BRANINE, M.E.; SOWELL, B.; WALLACE, J.D. Influence of ruminally dispensed monensin and forage maturity on intake and digestion. Journal of Range Management, v.46, n.3, p.214-220, 1993.

FUNK, M.A.; GALYEAN, M.L.; ROSS, T.T. Potassium and lasalocid effects on performance and digestion in lambs. Journal of Animal Science, v.63, n.3, p.685691, 1986.

GALLOWAY Sr., D.L.; GOETSCH, A.L.; PATIL, A.; FORSTER Jr.; L.A.; JOHNSON, Z.B. Feed intake and digestion by Holstein steer calves consuming low-quality grass supplemented with lasalocid or monensina. Canadian Journal of Animal Science, v.73, n.4, p.869-879, 1993.

GANEV, G.; ØRSKOV, E.R.; SMART, R. The effect of roughage or concentrate feeding and rumen retention time on total degradation of protein in the rumen. Journal of Agriculture Science, v.93, p.651-656, 1979.

GARCIA-LOPEZ, P.M.; KUNG, L.; ODOM, J.M. In vitro inhibition of microbial methane production by 9,10-Anthraquinone. Journal of Animal Science, v.74, p.2276-2284, 1996.

GOERING, H.K.; VAN SOEST, P.J. Forage fiber analysis (Apparatus, reagents, procedures and some applications). Agriculture Handbook, Washington D.C.: Agricultural Research Service, 1970. p.19.

GOMEZ, L.; BOGAËRT, C.; JOUANY, J.P.; LASSALAS, B. The influence of lasalocid and cationomycin on nitrogen digestion in sheep: comparison of methods for estimating microbiol nitrogen. Canadian Journal of Animal Science, v.71, n.2, p.389-399, 1991.

GOODRICH, R.D.; GARRET, J.E.; GAST, D.R.; KIRICK, M.A.; LARSON, D.A.; MEISKE, J.C. Influence of monensin on the performance of cattle. Journal of Animal Science, v. 58, n.6, p.1484-1498, 1984.

GRANER, C.A.F. Determinação do crômio pelo método colorimétrico da sdifenilcarbazida. Botucatu, 1972. 112p. Dissertação (Mestrado) - Faculdade de Ciências Médicas e Biológicas, Universidade Estadual Paulista.

GREEN, B.L.; McBRIDE, B.W.; SANDALS, D.; LESLIE, K.E.; BAGG, R.; DICK, P. The impact of a monensin controlled-release capsule on subclinical ketosis in the transition dairy cow. Journal of Dairy Science, v.82, n. 2, p.333-342, 1999. 
HAIMOUD, A.D.; VERNAY, M.; BAYOURTHE, C.; MONCOULON, R. Avoparcin and monensin effects on the digestion of nutrients in dairy cows fed a mixed diet. Canadian Journal of Animal Science, v.75, n.3, p.379-385, 1995.

HAIMOUD, A.D.; BAYOURTHE, C.; MONCOULON, R.; VERNAY, M. Avoparcin and monensin effects on digestive function in cows fed a high forage diet. Journal of the Science of Food and Agriculture, v.70, n.2, p. 181-189, 1996.

HANSON, T.L.; KLOPFENSTEIN, T.J. Monensin, protein source and protein levels for growing steers. Journal of Animal Science, v.48, n.3, p.474-479, 1979.

HEFNER, D.L.; HAROLD, F.M. ATPdriven sodium pump in Streptococcus faecalis. Proc. Natl. Sci., USA, v.79, p.2798, 1982.

HERALD, F.; KNAPP, F.W.; BROWN, S.; BRADLEY, N.W. Efficacy of monensin as a cattle feed additive against the face fly and horn fly. Journal of Animal Science, v.54, n.6, p.1128-1131, 1982.

HINO, T.; SAITOH, H.; MIWA, T.; KANDA, M.; KUMAZAWA, S. Effect of aibellin, a peptide antibiotic, on propionate production in the rumen of goats. Journal of Dairy Science, v.77, n.11, p.3426-3431, 1994.

HORTON, G.M.J.; BASSENDOWSKI, K.A.; KEELER, E.H. Digestion and metabolism in lambs and steers fed monensin with different levels of barley. Journal of Animal Science, v.50, n.6, p.997-1008, 1980.

HUNGATE, R.E. The Rumen and its Microbes, New York: Academic Press, 1966. p.206.

HYDEN, S. A turbidometric method for the determination of higher polyethylene glycols in biological materials. K. Lantbr. Hogsk. Arbb., v.22, p.139-145, 1956.

IVAN, M.; DAYRELL, M.S.; HIDIROGLOU, M. Effects of bentonite and monensin on selected elements in the stomach and liver of fauna-free and faunated sheep. Journal of Dairy Science, v.75, n. 1, p.201-208, 1992.

JACQUES, K.A.; COCHRAN, R.C.; CORRAH, L.R.; AVERY, T.B.; ZOELLNER, K.O.; HIGGINBOTHAM, J.F. Influence of lasalocid level on forage intake, digestibility, ruminal fermentation liquid flow and performance of beef cattle grazing winter range. Journal of Animal Science, v.65, n.3, p.777-785, 1987.

JOHNSON Jr., J.C.; UTLEY, P.R.; MULLINIX Jr., B.G.; MERRILL, A. Effects of adding fat and lasalocid to diets of dairy cows. Journal of Dairy Science, v.71, n.8, p.2151-2165, 1988. 
JOYNER, A.E.; BROWN, L.J.; FOGG, T.J.; ROSSI, R.T. Effects of monensin on growth, feed efficiency and energy metabolism of lambs. Journal of Animal Science, v.48, n.5, p.1065-1069, 1979.

KATZ, M.P.; NAGARAJA, T.G.; FINA, L.R. Ruminal changes in monensin and lasalocid fed cattle grazing bloat provocative alfafa pasture. Journal of Animal Science, v. 73, n.4, p. 1246-1257, 1986.

KNOWLTON, K.F.; ALLEN, M.S.; ERICKSON, P.S. Lasalocid and particle size of corn for dairy cows in early lactation. 1. Effect on performance, serum metabolites, and nutrient digestibility. Journal of Dairy Scien ce, v.79, n.4, p.557-564, 1996a.

KNOWLTON, K.F.; ALLEN, M.S.; ERICKSON, P.S. Lasalocid and particle size of corn for dairy cows in early lactation. 2. Effect on ruminal measurements and feeding behavior. Journal of Dairy Science, v.79, n. 4, p.565-574, $1996 \mathrm{~b}$.

KULASEK, G. A micromethod for determination of urea in plasma, whole blood and blood cells using urease and phenol reagent. Pol. Arch. Wet., v.15, n.4, p.801-810, 1972.

LANA, R.P.; RUSSELL, J.B. Use of potassium depletion to assess adaptation of ruminal bacteria to ionophores. Applied Environmental Microbiology, v.62, n.12, p.4499-4503, 1996.

LANA, R.P.; RUSSELL, J.B. Effect of forage quality and monensin on the ruminal fermentation of fistulated cows fed continuosly at a constant intake. Journal of Animal Science, v.75, n. 1, p.224-229, 1997.

LEE, S.K.; LEE, B.D.; JUNG, K.K.; PARK, H.S. Effect of feeding monensin on the feed intake, nutrient utilization and ruminal fermentation of Korean native goat. Nutrition Abstracts and Reviews, v.62, p.448, 1992.

LEEDLE, J.A.Z.; HESPELL, R.B. Differencial carbohydrate media and anaerobica replica plating techniques in delineating carbohydrate utilizing subgroups in rumen bacterial populations. Applied Environmental Microbiology, v.39, p.709, 1980.

LEMENAGER, R.P.; OWENS, F.N.; SHOCKEY, B.J.; LUSBY, K.S.; TOTUSEK, R. Monensin effects on rumen turnover rate, twenty-four hour VFA pattern, nitrogen components and cellulose disappearance. Journal of Animal Science, v.47, n.l, p.255-261, 1978.

LINDBERG, J.E. The effect of basal diet on the ruminal degradation of dry matter, nitrogenous compounds and cell walls in nylon bags roughage and cereals in varius 
proportions. Swedish Journal of Agricutural Research, v.11, n.4, p.159-169, 1981a.

LINDBERG, J.E. Rumen degradation pattern of dry matter and nitrogenous compounds of some concentrates studied with the nylon bag technique. Swedish Journal of Agricutural Research, v.11, n.4, p.171-176, $1981 \mathrm{~b}$.

LINDBERG, J.E. The effect of sample size and sample structure on the degradation of dry matter, nitrogen and cell walls in nylon bags. Swedish Journal of Agricutural Research, v.11, n.2, p.71-76, 1981c.

LPIEC, A.; TARKOWSKI, A.; KLOCEK, B. A comparison of the digestibility of fiber and its fractions of some feeds for cattle (1988). Nutrition Abstracts and Reviews, v.61, p.656, 1991.

MACHADO, P.F. Estudo dos efeitos da combinação isoácidos - monensina sobre a fermentação ruminal e desempenho de vacas em lactação. Piracicaba, 1988. 100p. Tese (Livre Docência) - Escola Superior de Agricultura "Luiz de Queiroz", Universidade de São Paulo.

MAROUNEK, M.; PETR, O.; MACHAÑOVÁ, L. Effect of monensin on in vitro fermentation of maize starch by hindgut contents of cattle. Journal of Agricultural Science, v.115, p.389-392, 1990.

McCANN, M.A.; CRADDOCH, B.F.; PRESTON, R.L.; RANSEY, C.B. Digestibility of cotton plant by-products diets for sheep at two levels of intake. Journal of Animal Science, v.68, n.2, p.285-295, 1990.

McCARTOR, M.M.; RANDEL, R.D.; CARROLL, L.H. Dietary alteration of ruminal fermentation on efficiency of growth and onset of puberty in Brangus heifers. Journal of Animal Science, v.48, n.3, p.488-494, 1979.

McCAGHEY, W.P.; WITTENBERG, K.; CORRIGAN, D. Methane production by steers on pasture. Canadian Journal of Animal Science, v.77, n.3, p.519-524, 1997.

MEHRES, A.Z.; ØRSKOV, E.R. A study of the artificial fiber bag technique for determining the digestibility of feeds in the rumen. Journal of Agriculture Science, v.88, p.645-650, 1977.

MEHRES, A.Z.; ØRSKOV, E.R.; McDONALD, I. Rates fermentation in relation to ammonia concentration. The British Journal of Nutrition, v.38, n.3, p.437-443, 1977 
MORRIS, F.E.; BRANINE, M.E.; GALUEN, M.L.; HUBBERT, M.E.; FREEMAN, A.S.; LOFGREEN, G.P. Effects of rotating monensin plus tylosin and lasalocid on performance, ruminal fermentation, and site and extent of digestion in feedlot cattle. Journal of Animal Science, v.68, n.10, p.3069-3078, 1990.

MOULD, F.L.; ØRSKOV, E.R.; MANN, S.O. Associative effects of mixed feeds. 1. Effects of type and level of supplementation and the influence of the rumen fluid $\mathrm{pH}$ on cellulolysis in vivo and dry matter digestion of various roughages. Animal Feed Science and Technology, v. 10, p. 15-30, 1983.

NOCEK, J.E.; RUSSELL, J.B. Protein and energy as an integrated system. Relationship of ruminal protein and carbohydrate availability to microbial sinthesis and milk production. Journal of Dairy Science, v.71, n.8, p.2070-2107, 1988.

ØRSKOV, E.R. Protein Nutrition in Ruminants. San Diego: Academic Press, 1982. $160 \mathrm{p}$.

ØRSKOV, E.R.; HOVELL, F.D.Deb.; MOULD, F. Uso de la tecnica de la bolsa de nylon para la avaluacion de los alimentos. Producción Animal Tropical, v.5, n.3, p.213-233, 1980.

ØRSKOV, E.R.; McDONALD, I. The estimation of protein degradability in the rumen from incubation measurements weighed according to rate of passage. Journal of Agriculture Science, v.92, p.499-503, 1979.

OTT, R.L. An introduction to statistical methods and data analysis. Wadsworth, 1983.

OVCHINNIKOV, J.A. Physico chemical basis of ion transport through biological membranes: Ionophores and ion channels. Europeam Journal of Biochemistry, v.94, p.321-336, 1979.

PATERSON, J.A.; ANDERSON, B.M.; BOWMAN, D.K.; MORRISON, R.L.; WILLIAMS, J.E. Effect of protein source and lasalocid on nitrogen digestibility and growth by ruminants. Journal of Animal Science, v.57, n.6, p. 1537-1544, 1983.

PEIXOTO Jr., K.C. Efeitos de tempos de ação e niveis de lasalocida sódica sobre a degradabilidade de alimentos no rúmen, em bovinos. Pirassununga, 1998. 96p. Dissertação (Mestrado) - Faculdade de Medicina Veterinária e Zootecnia, Universidade de São Paulo.

PIMENTEL GOMES, F. Curso de Estatística Experimental. Piracicaba-SP: ESALQ, 1985. 467p. 
PISULEWSKI, P.M.; OKORIE, A.U.; BUTTERY, P.J.; HARESIGN, W.; LEWIS, D. Ammonia concentration and protein synthesis in the rumen. Journal of the Science of Food and Agriculture, v. 32, n. 8, p.759-766, 1981.

POMAR, C.; BERNIER, J.F.; SEOANE, F.R.; LATRILE, L. High-roughage rations with or without monensin for veal production. 2.Ration digestibility. Canadian Journal of Animal Science, v.69, n.2, p.403-410, 1989.

POOS, M.I.; HANSON, T.L.; KLOPFENSTEIN, T.J. Monensin effects on diet digestibility, ruminal protein bypass and microbial protein synthesis. Journal of Animal Science, v.48, n.6, p.1516-1524, 1979.

PRESTON, T.R.; LENG, R.A. Matching ruminant prodution systems with avaliable resourses in the tropics and sub-tropics. Anmidale: Penambul Books, 1987. 245p.

RAMANZIN, M.; BAILONI, L.; SCHIAVON, S.; BITTANTE, G.; Effect of monensin on milk production and efficiency of dairy cows fed two diets differing in forage to concentrate ratios. Journal of Dairy Science, v.80, n.6, p.1136-1142, 1997.

RAUN, A.P.; COOLEY, C.O.; POTTER, E.L.; RATHMATHER, R.P.; RICHARDSON, L.F. Effect of monensin on feed efficiency of feedlot cattle. Journal of Animal Science, v.43, n.3, p.670-677, 1976.

REFFETT-STABEL, J.; SPEARS, J.W.; HARVEY, R.W.; LUCAS, D.M. Salinomycin and lasalocid effects on growth rate, mineral metabolism and ruminal fermentation in steers. Journal of Animal Science, v.67, n. 10, p.2735-2742, 1989.

RICHARDSON, L.F.; RAUN, A.P.; POTTER, E.L.; COOLEY, C.O. Effect of monensin in rumen fermentation in vitro and in vivo. Journal of Animal Science, v.43, n.3, p.657-664, 1976.

RICHTER, G.H.; FLACHOWSKI, G. Influence of lasalocid on apparent digestibility, rumen fermentation, fattening and slauhgtering performance of bulls. Archives of Animal Nutrition, v.40, p.981, 1990.

RICKE, S.C.; BERGER, L.L.; VAN DER AAR, P.J·; FAHEY, G.C. Effects of lasalocid and monensin on nutrient digestion, metabolism and rumen characteristics of sheep. Journal of Animal Science, v.58, n.1, p.194-202, 1984.

RODE, L.M.; WEAKLEY, D.C.; SATTER, L.D. Effect of forage amount and particle size in diets of lactanting dairy cows on site of digestion nad microbial protein synthesis. Canadian Journal of Animal Science, v.65, n. 1, p.101-111, 1985. 
RODRIGUES, P.H.M. Efeitos da lasalocida sódica e proporção volumoso/concentrados sobre a fermentação ruminal e degradabilidade in situ do farelo de soja e do feno Coast Cross (Cynodon dactylon). Pirassununga, 1996. 135p. Tese (Mestrado) - Faculdade de Medicina Veterinária e Zootecnia, Universidade de São Paulo.

RODRIGUEZ, S.L.; CRAIG, W.M.; HEMBRY, F.G. Changes in ruminal concentrations of microbial ammonia and amino acids due to monensin and time. Journal of Animal Science, v.63, n.6, p. 1990-1995, 1986.

ROGERS, J.A.; DAVIS, C.L. Rumen volatile fatty acid production and nutrient utilization in steers fed a diet supplemented with sodium bicarbonate end monensin. Journal of Dairy Science, v.65, n.6, p.944-952, 1982.

ROUSH, W.B.; PETERSEN, R.G.; ARSCOTT, G.H. An application of response surface metodology to research in poultry nutrition. Poultry Science, v. 58, p. 1504$1513,1979$.

RUMSEY, T.S. Monensin in cattle: introduction. Journal of Animal Science, v.58, n.6, p. 1461-1464, 1984.

RUSSELL, J.B.; STROBEL, H.J.; CHEN, G. The enrichment and isolation of a ruminal bacterium with a very high specific activity of ammonia production. Applied Environmental Microbiology, v.54, p.872, 1988.

RUSSELL, J.B.; STROBEL, H.J. Minireview: Effect of ionophores on ruminal fermentation. Applied Environmental Microbiology, v.54, p. 1, 1989.

SALLES, M.S.V. Monensina para bezerro em crescimento acelerado. Pirassununga, 1997. 63p. Dissertação (Mestrado) - Faculdade de Medicina Veterinária e Zootecnia, Universidade de São Paulo.

SANTOS, F.A.P. Efeito de bicarbonato de sódio, lasalocida e cana-de-açúcar sobre o desempenho de bovinos alimentados com bagaço de cana tratado sob pressão de vapor. Piracicaba, 1991. 127p. Dissertação (Mestrado) - Escola Superior de Agricultura "Luiz de Queiroz", Universidade de São Paulo.

SAS Institute Inc. SAS User's guide: statistics. 5.ed., Cary-NC: SAS Inst., 1985.

SATTER, L.D.; SLYTER, L.L. Effect of ammonia concentration on rumen microbial protein production in vitro. British Jounal of Nutrition, v.32, p. 199-208, 1974.

SAUER, F.D.; KRAMER, J.K.; CANTWELL, W.J. Anticetogenic effect of monensin in the early lactancy. Journal of Dairy Science, v.72, n.2, p.436-442, 1989. 
SAUER, F.D.; FELLNER, V.; KINSMAN, R.; KRAMER, J.K.G.; JACKSON, H.A.; LEE, A.J.; CHEN, S. Methane output and lactation response in Holstein cattle with monensin or unsaturated fat added to the diet. Journal of Animal Science, v.76, p.906-914, 1997.

SCHELLING, G.T. Monensin mode of action in the rumen. Journal of Animal Science, v.58, n.6, p.1518-1527, 1984.

SILVA, D.J. Análises de Alimentos (Métodos Químicos e Biológicos), Viçosa: Imprensssa Univesitária da Universidade Federal de Viçosa, 1981.

SIMPSON, M.E. Effects of certain antibiotics in vitro cellulose digetibility and volatile fatty acid (VFA) production by ruminal microorganisms. Journal of Animal Science, v.47, 1978. p.429, suplemento 1 .

SIP, M.L.; PRITCHARD, R.H. Nitrogen utilization by ruminants during restricted intake of high-concentrate diets. Journal of Animal Science, v.69, n.6, p.2655$2662,1991$.

SMTTH, G.E. Energy metabolism, Digestive Physiology and Nutrition of Ruminants, Corvalis-OR: O and B Books, 1971.601 p.

STARNES, S.R.; SPEARS, J.W.; FROETSCHEL, M.A.; CROOM, W.J. Influence of monensin and lasalocid on mineral metabolism and ruminal urease activity insteers. Journal of Nutrition, v.114, n.3, p.518-525, 1984.

STEEN, T.M.; QUIGLEY, J.D.; HEITMANN, R.N.; GRESHAM, J.D. Effects of lasalocid and undegradable protein on growth and body composition of Holstein heifers. Journal of Dairy Science, v.75, n.9, p.2517-2523, 1992.

STEPHENSON, K.A.; LEAN, I.J.; HYDE, M.L.; CURTIS, M.A.; GARVIN, J.K.; LOWE, L.B. Effects of monensin on the metabolism of periparturient dairy cows. Journal of Dairy Science, v. 80, n.5, p.830-837, 1997.

SUBER, L.M.; BOWMAN, J.G. Monensin effects on digestion of corn or barley highconcentrate diets. Journal of Animal Science, v.76, n.7, p. 1945-1954, 1998.

SUSMEL, P.; STEFANON, B.; PIASENTIER, E. Effect of forage and a concentrate intake level on rumen degradability of protein sources having different in vitro rates of N solubilisation. Animal Feed Science and Technology, v.26, n.3/4, p.231-249, 1989.

TANNER, J.W.; BYERS, F.M.; ELLIS, W.C.; SCHELLING, G.T.; GREENE, L.W. Effect of two ionophores on digestibility, gastrointestinal fill and utilization of 
winter pasture by grazing heifers. Journal of Animal Science, v.59, 1984. p.67, suplemento, 1.

THORNTON, J.H.; OWENS, F.N. Monensin supplementation and in vivo methane production by steers. Journal of Animal Science, v. 52, n.3, p.628-634, 1981.

TURNER, H.A.; YOUNG, D.C.; RALEIGH, R.J.; DALE ZOBEL. Effect of variuos levels of monensin on efficiency and production of beef cows. Journal of Animal Science, v. 50, n.3, p.385-390, 1980.

VAGNONI, D.B.; CRAIG, W.M.; GATES, R.N.; WYATT, W.E.; SOUTHERN, L.L. Monensin and ammoniation or urea supplementation of bermudagrass hay diets for steers. Journal of Animal Science, v.73, n.6, p. 1793-1802, 1995.

VAN KESSEL, J.S.; RUSSELL, J.B. Energetics of arginine and lysine transport by whole cells and membrane vesicles of strain SR, a monensin-sensitive ruminal bacterium. Applied Environmental Microbiology, v.58, n.3, p.969-975, 1992.

VAN MAANEN, R.W.; HERBEIN, J.H.; McGILLIARD, A.D.; YOUNG, J.W. Effects of monensin in vivo rumen propionate production and blood glucose kinetics in cattle. Journal of Nutrition, v. 108, p. 1002-1007, 1978.

VAN NEVEL, C.J.; DEMEYER, D.I. Effect of monensin on rumen metabolism in vitro. Applied Environmental Microbiology, v.34, n.3, p.251-257, 1977.

VAN NEVEL, C.J.; DEMEYER, D.I. Lipolysis and biohydrogenation of soybean oil in the rumen in vitro: inhibition by antimicrobials. Journal of Dairy Science, v.78, n. 12, p.2797-2806, 1995.

VAN SOEST, P.J. Nutritional Ecology of the Ruminant. USA: O \& B Books, Inc., 1983. 674p.

WAMPLER, J.L.; MARTIN, S.A.; HILL, G.M. Effects of laidlomycin propionate and monensin on glucose utilization and nutrient transport by Streptococcus bovis and Selenomonas ruminantium. Journal of Animal Science, v.76, n.10, p.2730-2736, 1998.

WEAKLEY, D.C.; STERN, M.D.; SATTER, L.D. Factors affecting disappearance of feedstuffs from bags suspended in the rumen. Journal of Animal Science, v. 56, n.2, p.493-507, 1983.

WEDEGAERTNER, T.C.; JOHNSON, D.E. Monensin effects on digestion, methanogenesis and heat increment of a cracked corn-silage diet fed to steers. Journal of Animal Science, v.57, n. 1, p. 168-177, 1983. 
WEISS, W.P.; AMIET, B.A. Effect of lasalocid on performance of lactating cows. Journal of Dairy Science, v.73, n. 1, p.153-162, 1990.

WESSELS, R.H.; TITGEMEYER, E.C.; ARMENDARIZ, C.K.; JEAN, G.S. Lasalocid effects on ruminal degradation of protein and postruminal supply of amino acids in Hostein steers. Journal of Dairy Science, v.79, n. 10, p. 1802-1808, 1996.

WHETSTONE, H.D.; DAVIS, C.L.; BRYANT, M.P. Effect of monensin on breakdown of protein by ruminal microorganisms in vitro. Journal of Animal Science, v.53, n.3, p.803-809, 1981.

WOHLT, J.E.; CLARK, J.H.; BLAISDELL, F.S. Effects of sampling location, time and method of concentration of ammonia nitrogen in the rumen. Journal of Dairy Science, v.59, n.3, p.459-464, 1976.

YANG, C.M.J.; RUSSELL, J.B. The effect of monensin supplementation on ruminal ammonia accumulation in vivo and the numbers of amino acid-fermenting bacteria. Journal of Animal Science, v.71, n. 12, p.3470-3476, 1993.

ZINN, R.A. Influence of lasalocid and monensin plus tylosin on comparative feeding value of steam-flaked versus dry-rolled corn in diets for feedlot cattle. Journal of Animal Science, v.65, n.1, p.256-266, 1987.

ZINN, R.A.; BORQUES, J.L. Influence of sodium bicarbonate and monensin on utilization of a fat-supplemented, high-energy growing-finishing diet by feedlot steers. Journal of Animal Science, v.71, n. 1, p. 18-25, 1993.

ZINN, R.A; PLASCENCIA, A.; BARAJAS, R. Interaction of forage level and monensin in diets for feedlot cattle on growth performance and digestive function. Journal of Animal Science, v.72, p.2209-2215, 1994. 